
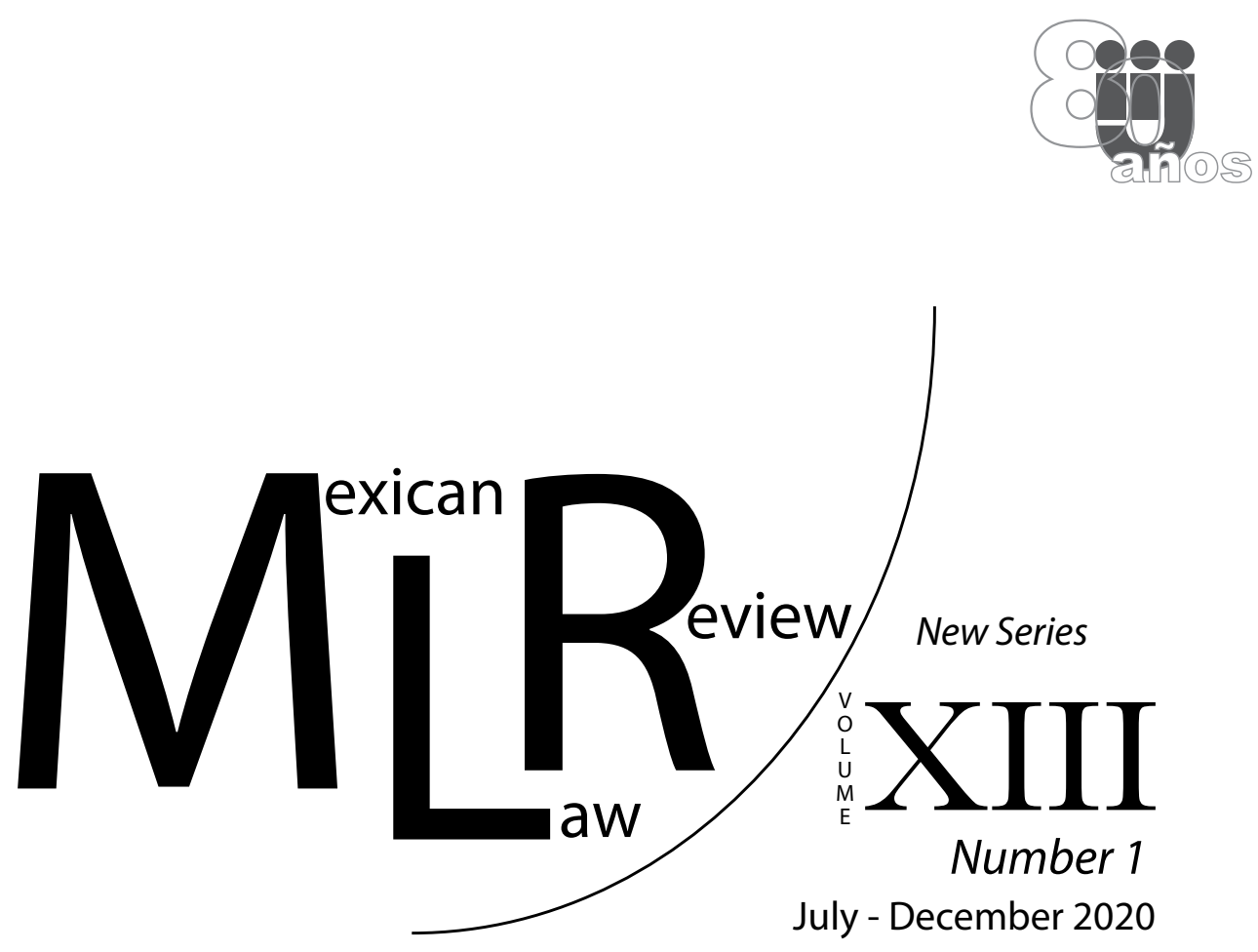

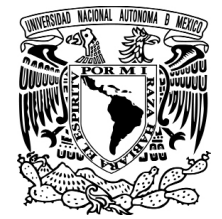

UNIVERSIDAD NACIONAL AUTÓNOMA DE MÉXICO

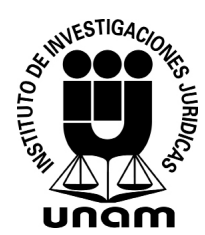

INSTITUTO DE INVESTIGACIONES JURÍDICAS 


\section{Mexican Law Review}

New Series

July - December $2020 \quad$ Volume XIII, Number 1

Editor-in-Chief

John M. Ackerman

Executive Editor

Wendy Rocha

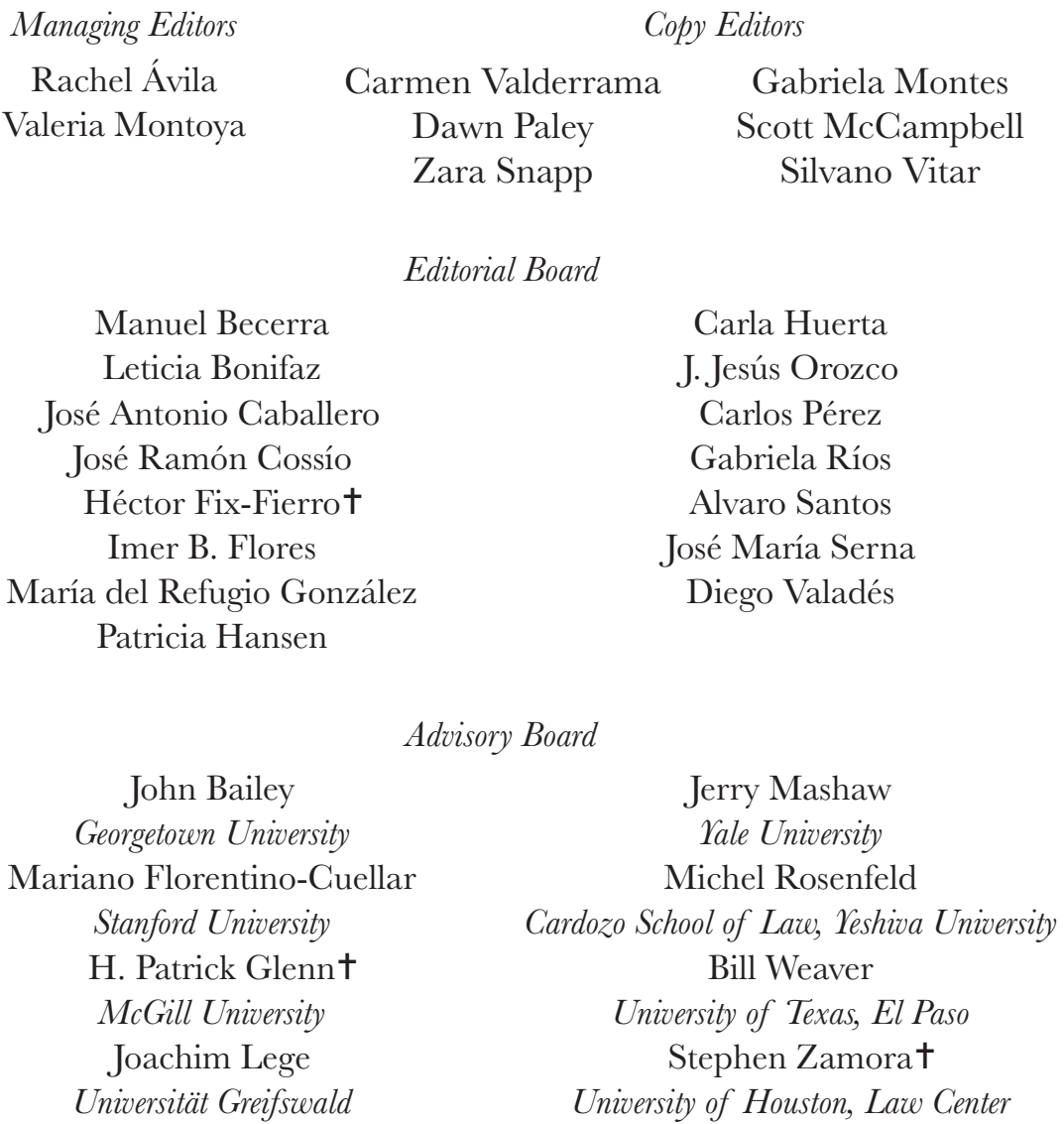

Interior design: Wendy V. Rocha Cacho 


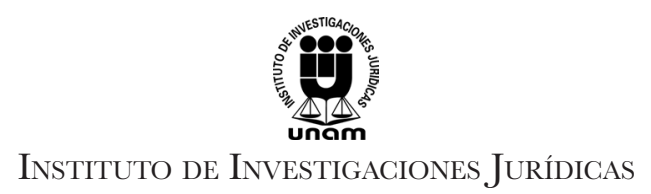

\author{
Pedro Salazar \\ Director \\ Issa Luna \\ Secretaria académica \\ Raúl Márquez \\ Secretario técnico \\ Wendy Rocha \\ Jefa del Departamento de Publicaciones
}

Mexican Law Review, nueva serie, vol. XIII, núm. 1, julio-diciembre de 2020, es una publicación semestral editada por la Universidad Nacional Autónoma de México, Ciudad Universitaria, Coyoacán, 04510 Ciudad de México, a través del Instituto de Investigaciones Jurídicas, Circuito Maestro Mario de la Cueva s/n, Ciudad Universitaria, Coyoacán, 04510 Ciudad de México, teléfono 5622 7474, correo electrónico: ackerman@unam.mx. Editor responsable: John Mill Ackerman Rose. Certificado de Reserva de Derechos al Uso Exclusivo núm. 04-2010-102014301100-102. ISSN: 1870-0578.

Mexican Law Review por Universidad Nacional Autónoma de México, Instituto de Investigaciones Jurídicas, se distribuye bajo una Licencia Creative Commons Reconocimiento-No Comercial-Sin Derivados 4.0 Internacional (CG BY-NG-ND 4.0).

El contenido de los artículos es responsabilidad de los autores y no refleja necesariamente el punto de vista de los árbitros ni del editor.

Primera edición: 2 de julio de 2020

Mexican Law Review se encuentra registrada en los siguientes índices y bases de datos: Sistema de clasificación de Revistas Mexicanas de Ciencia y TecnologíaConacyt (competencia internacional); SGOPUS; Latindex; Clase; Periodica; Scielo (Scientific Electronic Library Online); Biblat (Indicadores Bibliométricos); DiALNET. 


\section{Mexican Law Review}

New Series

July - December $2020 \quad$ Volume XIII, Number 1

\section{ARTICLES}

Cybersecurity and E-commerce in Free

Trade Agreements

Anahiby Becerril

The State of Emergency as an

Instrument to Overcome Organized

Crime and Vigilantes: A Comparative

Felipe Carlos Betancourt

Study of Michoacán and Guerrero

Higareda

Enrique Uribe Arzate

Claudia Angélica

Córdova González

Mónica Guadalupe

Chávez Elorza

65

to Free Trade Agreements

Yoomin Won

101 AND SOUTh Korea

Raúl Iturralde

González

Mexican Commercial Gode

Forge Gabriel Arévalo

García 
NOTE

Drafting a Constitution Is Not

Drafting a Statute: An Analysis

of the Mexican Constitution and

Hyper-Amending Pathologies from

Jesús Manuel Orozco

the Legislative Drafting Perspective

Pulido 
Esta revista forma parte del acervo de la Biblioteca Jurídica Virtual del Instituto de Investigaciones Jurídicas de la UNAM juhttp://www.juridicas.unam.mx/

\section{ARTICLES}




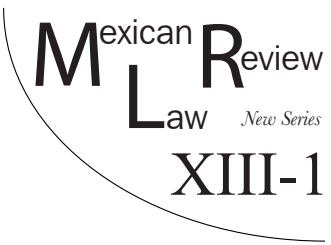

\title{
GYBERSEGURITY AND E-COMMERCE IN FREE TRADE AGREEMENTS
}

\author{
Anahiby BECERRIL*
}

\begin{abstract}
We are facing a digital age characterized by constant flows of goods and services, financial assets, people, information and communication. As a consequence, the world economy is increasingly connected, and digitalization has spread to such an extent that today's world economy is a digital one, which has come to break down commercial barriers that the traditional economy and politics were unable to. Security and trade policy concerns are nothing new. However, given the electronic nature of commercial transactions (e-commerce), this has taken on a new and urgent importance. Cyberspace is a space of flows, a virtual space that growes every day with the transactions that take place through the use of ICT. Governments of many countries have begun to develop cybersecurity strategies, while trying to promote the benefits of a hyperconnected and cyber-enabled world. This article analyzes how e-commerce policies promote the protection of cyberspace. Specifically regarding e-commerce, care must be taken so that the cybersecurity strategy does not become an obstacle or constraint to such electronic transactions. The protection of cyberspace must be carried out with a multi-stakeholder approach. These issues are also of public interest since threats to cyberspace can affect entire countries and societies.
\end{abstract}

Keywords: Cyberspace, cybersecurity, e-commerce, treaties.

RESUMEN: Nos enfrentamos a una era digital caracterizada por flujos constantes de bienes y servicios, activos financieros, personas, información y comunicación. Como consecuencia de lo anterior, la economía mundial está cada vez más conectada, y la digitalización se ha extendido hasta tal punto que la economía mundial actual es una economía digital. Esta economía digital ha llegado a romper las barreras comerciales que la economía y la política tradicionales no habian logrado. Las preocupaciones sobre la seguridad y las políticas comerciales no son nuevas. Sin embargo, dada la naturaleza electrónica de las transacciones comerciales (comercio electrónico), esta ha adquirido una importancia nueva y urgente. El ciberespacio es un espacio de flujos, un

* PhD in Law and Globalization, Cybersecurity Law Specialist. Professor at the National Autonomous University of Mexico, UNAM. Email: anahiby@hotmail.com. 
espacio virtual que crece diariamente con las interacciones que se realizan con el uso de las TIC. Los gobiernos de muchos países han comenzado a desarrollar estrategias de ciberseguridad, mientras intentan promover los beneficios de un mundo hiperconectado y con acceso a Internet. En este artículo analizaremos cómo, a través de las políticas de comercio electrónico, se promueve la protección del ciberespacio. En relación con el comercio electrónico, se debe buscar que una estrategia de ciberseguridad no se convierta en un obstáculo o una barrera para estas transacciones electrónicas. La protección del ciberespacio debe llevarse a cabo con un enfoque de múltiples partes interesadas. Estos temas también son de interés público, ya que las amenazas al ciberespacio pueden afectar a países $y$ sociedades enteras.

Palabras clave: Ciberespacio, ciberseguridad, comercio electrónico, tratados.

\section{TABle of Contents}

I. INTRODUCTION ........................................................................ 4

II. Electronic Commerce in the Global Digital Economy............... 9

1.The Digitization of Everything and the Increasing Amount of Information Available.

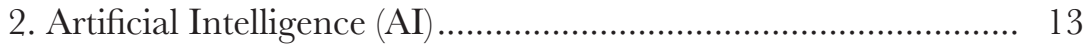

3. Big Data ............................................................................ 13

4. Internet of Things (IoT) .................................................... 14

5. Cloud Computing ............................................................ 14

6. Materials Based on "Bio-" or "Nano-" Technology ................... 15

III. From Gyberspace to Gybersecurity ......................................... 16

1. Cyberspace ........................................................................ 16

2. Cybersecurity ............................................................ 17

IV. Gybersecurity in Free Trade Agreements................................. 19

1. Association of Southeast Asian Nations (ASEAN) ................... 20

2. From TPP to GPTPP .......................................................... 21

3. The North American Free Trade Agreement (NAFTA) ............ 27

V. Final Considerations......................................................... 28

\section{INTRODUCTION}

"If you think technology can solve your security problems, then you don't understand the problems and you don't understand the technology". ${ }^{1}$

1 Bruce Schneier Secrets \& Lies, Digital Security in a Networked World, XXII (Wiley Publishing Inc., Indiana) (2004). 
We are facing a digital age characterized by constant flows of goods and services, financial assets, people, information and communication. This global flow is not new; what is new is its exponential growth in recent years, as a result of economic progress, particularly with the massive spread of Information and Communication Technologies (ICTs), specifically the Internet and the accessibility of connected mobile devices (such as smartphones).

The ability to link the physical world with each human activity, through sensors and networks, to obtain knowledge through advanced analysis is and will undoubtedly continue - transforming our daily lives, as well as the economy and society. The digitalization of things constitutes one of the great phenomena of recent years. Translating everything (documents, music, images, maps, ourselves) into bits transforms the way we understand and interact with the world. ${ }^{2}$

The global economy is increasingly connected, and digitization has spread to such an extent that today's global economy is a digital one. This is nourished to a large extent by the massification of cloud computing, as well as Big Data and advances in the Internet of Things (IoT) and Artificial Intelligence (AI).

Consider the following information: for The Internet in Real Time, the amount of data uploaded to the Internet in one second is 24,000 gigabytes (GB). ${ }^{3}$ Cisco $^{4}$ has estimated that annual global IP traffic will reach $3.3 \mathrm{ZB}^{5}$ (1000 Exabytes) by 2021. In 2016, global IP traffic was 1.2 ZB per year or 96 $\mathrm{EB}^{6}$ (billion GB) per month. By 2021, global IP traffic will reach $3.3 \mathrm{ZB}$ per year, or $278 \mathrm{~EB}$ per month. In its Visual Networking Index: Forecast and Methodology, 2016-2021 report, the Cisco predicts the volume of devices connected to IP networks to be three times greater than the world population. According to their estimates, there will be a 3.5-device-per-capita network by 2021, compared to 2.3 devices per capita in 2016. Accelerated in part by the increase and capabilities of the devices, IP traffic per capita will reach 35 GB in 2021, compared to $13 \mathrm{~GB}$ in 2016.

With lower costs and greater connectivity, ICT platforms have allowed goods and services to flow through electronic commerce (e-commerce). The commercial transactions that are reflected in the use of information circulate through this "meta-space that is cyberspace", 7 without having to physically

2 Anahiby Becerril \& Samuel Ortigoza Limón, Habilitadores tecnológicos y realidades del Derecho Informático Empresarial, 41, IUS, Revista del Instituto de Giencias Jurídicas de Puebla 11, 41, January-June (2018).

31 gigabyte $(\mathrm{GB})$ is an amount of information storage equivalent to $1000^{3}(1,000,000,000$ or one billion) bytes.

4 CISCO, CISCO Visual Networking Index: Forecast and Methodology, 2016-2021, https://wrere. cisco.com/c/dam/en/us/solutions/collateral/service-provider/visual-networking-index-vni/complete-whitepaper-c11-481360.pdf.

51 zettabyte $(\mathrm{ZB})$ is a storage unit equivalent to $1000^{7}$ (one trillion) gigabytes.

61 exabyte $(\mathrm{EB})$ is a unit of measurement of data storage that equals 1018 bytes.

7 Concept obtained from the Preamble to the Bill of Rights in Cyberspace, publish-ed by 
reside in any specific place, as seen in the relocation of the space erected by telecommunications. This has allowed commercial immediacy, which encourages e-commerce.

In 2017, world production of ICT goods and services represented around $6.5 \%$ of the world's Gross Domestic Product (GDP). ${ }^{8}$ In 2015, worldwide e-commerce sales reached an estimated $\$ 25.3$ billion US dollars (USD), ${ }^{9}$ a figure that continues to increase daily. It is estimated that worldwide e-commerce retail trade for 2017 reached US $\$ 2.290$ billion, ${ }^{10}$ thus representing one tenth of total retail sales worldwide.

According to a study by the Association of Internet.mx, it is estimated that the value of the Mexican e-commerce market for 2017 was USD 396.04 billion, which constitutes a $20.1 \%$ increase over the previous year. ${ }^{11}$ In this sense, international e-commerce purchases that take place in Mexico constitutes $75 \%$ of its total users. ${ }^{12}$ With the digitization of everything, ICTs are leading up to an exponential increase in the available volume and types of data, creating countless possibilities to transform society and therefore countries. However, as individuals, governments, companies and societies in general, we are still at a stage of experimentation, innovation and adaptation to this new world of digital interactions, a world where at every moment the data contain greater volume, speed, variety than ever.

The dynamic economic sphere of cyberspace is experiencing great turmoil due to global forces of competition, cooperation and threats to cyberspace. These changes create confusion and uncertainty and can lead to the creation of strategies and policies that become barriers to electronic commerce and the digital economy.

EMiLIO SuÑÉ LLiNAS (2013), http://oiprodat.com/2013/04/21/declaracion-de-derechos-del-ciberespa ciol.

8 United Nations Conference on Trade and Development (UNCTAD), INForme SOBRE la economía de la información, 2017. Digitalización, comercio y desarrollo. Panorama GENERAL 2 (United Nations, New York) (2017).

9 Kimberly Boatwright, Sean Doherty, 5 Ways to Make Global E-Commerce Easier for Everyone (World Economic Forum) (2017), https://wwwreweforum.org/agenda/2017/12/ecommerce-trade-wtogrowth-opportunity/.

10 Emarketer, Worldwide Retail and Ecommerce Sales: Emarketer's Estimates for 2016-2021 (2017), https://wrerwemarketer.com/Report/Worldwide-Retail-Ecommerce-Sales-eMarketers-Estimates-201620 21/2002090.

11 However, this figure is down from the growth shown in 2016 that was $\$ 329.85$ million in relation to 2015 which was $\$ 257.09$ billion USD, which would imply an increase of 28.3\% between those years; see Asociación de Internet.mx, Estudio de Comercio Electrónico en México 2018, (2018) December, https://wrerceasociaciondeinternet.mx/es/component/remository/ func-startdown/72/lang,es-es/?Itemid=.

12 In 2016, it made up 60\%; see Asociación de Internet.mx, Estudio de Comercio Electrónico en México 2018 (2018) December, https://werwes:asociaciondeinternet.mx/es/component/remository/funcstartdown/72/lang,es-es/?Itemid $=$. 
Threats and incidents of digital security have increased in recent years and have had important economic and social consequences for public and private organizations, as well as for people. Some examples include interrupted operations (for example, by $D D_{0} S^{13}$ or sabotage), direct financial loss, lawsuits, damage to reputation, and diminished competitiveness (as in the case of theft of trade secret), as well as loss of customer trust.

The threats found in cyberspace are different since they do not come only from states, but from people and non-state actors who use it to promote their interests through malicious actions and behaviors. ${ }^{14}$ Unlike other domains such as water, land and sea, the purpose of carrying out attacks in cyberspace is not to have a domain over it, but so that, through it, use it to damage people, states and business.

To face risks and threats in cyberspace, most nations have contemplated an international commitment or obligation to cooperate with others and contribute to global cybersecurity. More and more in speeches from all over the world we hear that cooperation is vital to maintaining a secure cyberspace that promotes national security and stability for all users in general. An example of this is found in the Convention on Cybercrime, also known as the Budapest Convention, of the Council of Europe. ${ }^{15}$ This document clearly explains the importance of having appropriate legislative measures and international cooperation in the field of cybercrime.

Efforts to address issues related to security have also been carried out by intergovernmental organizations, such as the OAS ${ }^{16}$ - Organization of American States - , and the UN - United Nations - .17 This last one has issued

13 Distributed Denial of Service.

14 Derek S. Reveron, Cyberspace and National Security Threats, Opportunities, and Power in a Virtual World (Washington, DC., Georgetown University Press) (2012).

15 Signed in Budapest in 2001, it came into force in 2004. It has been signed by more than 53 states and is open to accession by countries that are not members of the Union. To date, Mexico has not adhered to this Convention.

16 With the unanimous approval of the Comprehensive Inter-American Cybersecurity Strategy in 2004, the OAS became the first regional organization to adopt a Cybersecurity Strategy, see Organization of American States, a Comprehensive Inter-American Cybersecurity Strategy: a Multidimensional and Multidisciplinary Approach for the Creation of a Culture of Cybersecurity (2004), http://wrere.oas.org/juridico/english/cyb_pry_estrategia.pdf; The Declaration on Strengthening Cyber Security in the Americas, OEA/Ser.L/X.2.12 CICTE/DEC.1/12 rev. 1, 9 March 2012, https://wrere.sbs. ox.ac.uk/cybersecurity-capacity/system/files/OAS\%20-\%20STRENGTHENI NG\%20CTBERSECURITT\%20IN\%20THE\%20AMERICAS.pdf; The Declaration on the Protection of Critical Infrastructure before Emerging Threats, OEA/Ser.L/X.2.15 CICTE/doc.1/15, 23 March 2015, https://wrews.sites. oas.org/cyber/Documents/CICTE\%20DOC\%201\%20DECLARATION\%20CICTE00955E04.pdf, as well as the OAS Cyber Security Initiative, https://wrere.sites.oas.org/cyber/Documents/2015\%20 Iniciativa\%20de\%20Seguridad\%20Cibern\%C3\%A9tica\%20de\%20la\%20OEA.PDF).

17 One example, among many others, is the creation of the Group on Information Security and Cybercrime and Cybersecurity. 
several recommendations emphasizing that "the dissemination and use of information technologies and means affect the interests of the entire international community", ${ }^{18}$ recognizing that "technologies can also be used for purposes that are inconsistent with the objectives of maintaining international stability and security".

In the same way, we find international institutions that have established formal standards, such as the International Telecommunications Union (ITU), the Internet Corporation for Assigned Names and Numbers (ICANN), ${ }^{19}$ the International Organization for Standardization (ISO), and the National Institute of Standards and Technology (NIST), among others.

Along the same strain, military, political and economic organizations such as the North Atlantic Treaty Organization (NATO),${ }^{20}$ the European Union, ${ }^{21}$ the Organization for Economic Co-operation and Development (OECD), ${ }^{22}$ the Association of Southeast Asian Nations (ASEAN) and the Asia-Pacific Economic Cooperation (APEG), the World Economic Forum (WEF), have also addressed issues of cybersecurity.

Derived from the importance of the global digital economy and market, instead of being treated as technical problems that require technical solutions, the risks in cyberspace must be addressed as economic risks. This is why this article analyzes the importance of cybersecurity for the promotion of e-

18 "...the dissemination and use of information technologies and means affect the interests of the entire international community"; see General Assembly of the United Nations, Preambles of Resolutions A/RES/55/28 November 20, 2000; A/RES/56/19 of November 29, 2001; A/RES/59/61 of December 3, 2004; A/RES/60/45 of December 8, 2005; A/ RES/61/54 of December 6, 2006; A/RES/62/17 of December 05, 2007; A/RES/63/37 of December 2, 2008; A/RES/64/25 of December 2, 2009. Preambles of Resolutions A/ RES/58/32 of December 08, 2003; A/RES/59/61 of December 3, 2004; A/RES/60/45 of December 8, 2005; A/RES/61/54 of December 6, 2006; A/RES/62/17 of December 5, 2007; A/RES/63/37 of December 2, 2008; A/RES/64/25 of December 2, 2009.

19 This association is in charge of the administration of the DNS (Domain Name System).

20 For example, the NATO Defense Center for Cyber Defense (NATO CCDCOE) was established in 2008 in an attempt to improve NATO's cyber defense capability.

21 The Cybersecurity Strategy of the European Union: An Open, Safe and Secure Cyberspace, presented in 2013, which in addition to establishing the Principles on cybersecurity, states, inter alia, its objective to "safeguard an online environment providing the highest possible freedom and security for the benefit of everyone"; JOIN/2013/01 final, https://eur-lex. europa.eu/legal-content/EN/TXT/?uri=CELEX\%3A520137C0001. Another example is the Directive on the security of network and information systems (NIS), which was introduced to strengthen cooperation among Member States on the subject of cybersecurity, European Parliament and Council of Europe, Directive (EU) 2016/1148, http://eur-lex.europa.eu/legal-content/ EN/TXT/PDF/? uri=CELEX:32016L1148Efrom =EN, among others.

22 In 1992, the OECD presented the Guidelines for the Security of Information Systems, http://wreweoecd.org/sti/ieconomy/oecdguidelinesforthesecurityofinformationsystems 1992.html; which were replaced in 2002 by the OECD Guidelines for the Security of Information Systems and Networks: Towards a Culture of Security, https://wrere.oecd.org/sti/ieconomy/15582260.pdf. 
commerce within the framework of free trade agreements. Though cybersecurity policies should be sought in the promotion of e-commerce, cyberspace protection measures and their infrastructures must be analyzed to determine that they do not constitute an obstacle to e-commerce. Therefore, we will first analyze the development of e-commerce as a driving force of the digital economy, mentioning the enablers and technologies that have fostered its development. Later, we will examine cyberspace in the cybersecurity environment to know the efforts that have been carried out for its protection. Through the knowledge of cyberspace and cybersecurity, a framework of cybersecurity will be built up by the countries that make up the Comprehensive and Progressive Agreement for Trans-Pacific Partnership (CPTPP), as it will be within the framework of the renegotiations of the North American free trade agreement. Lastly, a series of final considerations will be given.

\section{Electronic Commerce in the Global Digital Economy}

The new economy is global, but also digital; it evolves in real time and without borders. The economy is immersed in a global conversation, or digital interaction. It seems that the world is now united in a single electronic market, just a click away. The basis of commerce that develops in cyberspace is connectivity. The Internet, by its very nature, has knocked down the geopolitical boundaries that traditional commerce could not.

For the World Trade Organization (WTO), e-commerce constitutes: "the production, distribution, marketing, sale or delivery of goods and services by electronic means". ${ }^{23}$ While for the OECD this type of commerce constitutes "the sale or purchase of goods or services, performed by computer networks by methods specifically designed for the purpose of receiving or placing of place orders".24

In 1996, fulfilling its work of establishing friendly international economic relations, the United Nations Commission on International Trade Law (UNCITRAL) published its Model Law on Electronic Commerce, with Guide to Enactment. With this instrument, UNCITRAL sought to provide legal certainty and unify criteria in transactions that were developed via data messages, ${ }^{25}$ with the aim to progressively standardize and unify international

23 World Trade Organization, Work Programme on electronic Commerce, WT/L/ 274 (1998).

24 Organization for Economic Cooperation and Development (OECD), Glossary of Statistical Terms, https://stats.oecd.org/glossary/detail.asp?ID=4721.

25 The Model Law states that data message: "means information generated, sent, received or stored by electronic, optical or similar means including, but not limited to, electronic data interchange (EDI), electronic mail, telegram, telex or telecopy" (Article 2); see United Nations Commission on International Trade Law (UNCITRAL), Uncitral Model Law on Electronic Commerce with Guide to Enactment 1996 with Additional Article 5 Bis as Adopted in 1998 (United Nations 
commercial law. In its preamble, the UNCITRAL Model $\mathrm{Law}^{26}$ refers to "transactions in international trade are carried out by means of electronic data interchange and other means of communication", which "involve the use of alternatives to paper-based methods of communication and storage of information". ${ }^{27}$

In addition to highlighting the importance of e-commerce, the above definitions cover all kinds of commercial electronic transactions, including electronic funds transfers and credit card payments. However, such broad definitions are somehow obsolete as they do not recognize new forms of ecommerce, such as those done through the Internet (open networks) and limited to electronic transactions themselves, without referring to the spirit of this kind of business (cyberspace and virtual market, among others). Therefore, we consider the following, broader definition:

Electronic commerce includes the set of commercial transactions carried out by electronic or digital means of communication, either through open or closed networks, which is deployed within a global system, using computer and telecommunications networks (mainly the Internet), which create virtual markets of all kinds of products, goods and services in cyberspace. ${ }^{28}$

The economy that takes place in cyberspace groups companies into large networks of interdependent relationships in which these companies share activities and interests. ${ }^{29}$ Industrial companies have given their place to technical-scientific companies and to transnational network companies that base their services on software. And in some cases, they have become real-time companies, continuously and immediately adapting to the changing conditions of a new digital or hybrid environment, conditioned by the immediacy of information. An example of this is found in the new models of LegalTech, ${ }^{30}$

Organization, Vienna) (1999), https://wrere.uncitral.org/pdf/spanish/texts/electcom/05-89453_S_ Ebook.pdf.

26 Id. 2.

27 And while it highlights that many of the discussions are limited to the Internet, as the means with which it is mainly associated, the UNCITRAL Model Law of Electronic Commerce identifies six main instruments through which e-commerce can be carried out: telephone, fax, television, electronic payments and fund transfer systems, EDI and the Internet.

28 Víctor Manuel Gastrillón y Luna \& Anahiby Becerril, Contratación Electrónica Civil Internacional. Globalización, Internet y Derecho 167 (Porrúa, México) (2015).

29 Jeremy Rifkin, La Era del acceso. La revolución de la nueva economía 32 (Paidós, Barcelona) (2013).

30 Legal Technology, or "Legal Tech", is a term that broadly refers to the use of innovative technology and software to streamline and enhance legal services. Legal Tech companies are generally startups founded for the specific purpose of disrupting the operation of the (traditionally conservative) legal profession. See Micha-Manuel Bues \& Emilio Matthaei, LegalTech on the rise: technology changes legal work behaviors, but does not replace its profession, in LIQUID LEGAL: TRANS- 
RegTech ${ }^{31}$ and FinTech, ${ }^{32}$ all of which are companies that rely on new technologies like cloud computing, big data, artificial intelligence or blockchain, to create innovative solutions in providing services in their sector, bringing, in turn, more options for their users/customers.

In this way, the business organization has been restructured to adapt and get the most out of ICT. While the proper use of the Internet in companies previously meant a source of competitiveness and productivity, a digital strategy is now a fundamental part of the business plan. Electronic commerce not only benefits business-to-consumer (B2G) or business-to-business (B2B) commerce but has also strengthened consumer-to-consumer $(\mathrm{C} 2 \mathrm{C})$ trade. Platforms like eBay, Mercado Libre, and Amazon, among many others, have allowed small entrepreneurs and basically anyone to participate in international trade.

Another characteristic of this digital economy is the change of "traditional" roles of producers and consumers. By changing from a consumer Internet to a consumer and production Internet, we have become "prosumers". ${ }^{33}$ By becoming part of the production process with our knowledge, information and ideas, requesting or designing customized articles, or even uploading content to the network, the gap between consumers and producers is blurred. If the previous decade had brought us an internet of information, we are now witnessing the emergence of the Internet of value, which provides us with tools to achieve more active participation in the processes of services and products.

The rapidity with which this digital economy has developed is the result of the technologies and innovations that drive the Fourth Industrial Revolution. Multiple organizations have classified the technologies that are behind this new Industrial Revolution. However, if we consider that all these new technologies and developments share the key feature of harnessing the power generated by the digitalization of all things and ICT, we should have long

forming Legal Into a Business Savvy, Information Enabled and Performance Driven InDUSTRY (Springer Cham, 2017).

31 This term, created by the Financial Conduct Authority (FCA) of the United Kingdom, refers to companies that rely on new technologies such as cloud computing, big data or blockchain to create solutions to help companies of all sizes and sectors to comply with regulatory requirements. The FCA defines them as "new technologies to facilitate the delivery of regulatory requirements-so-called RegTech"; see Financial Conduct Authority, "Call for Input: Supporting the Development and Adoption of Regtech”, (FGA, UK) (2015), https://wrere. fca.org.uk/publication/call-for-input/regtech-call-for-input.pdf.

32 Several international organizations and national authorities have given different definitions to this technological evolution in the financial sector, from Financial Technology or FinTech to the term "technofinance". These concepts are used to describe advances in technology that can transform the provision of financial services and thus promote the development of new business models, applications, processes and products.

33 "The change of model has empowered users to become producers and, at the same time, consumers of information, services and media, which allows them to become suppliers and co-creators"; see Anahiby Becerril, Samuel Ortigoza Limón, supra note 17. 
ago questioned their safety and resilience. To learn about the challenges on its protection, we will briefly analyze the technologies that we consider are the key in the development of the digital economy. ${ }^{34}$

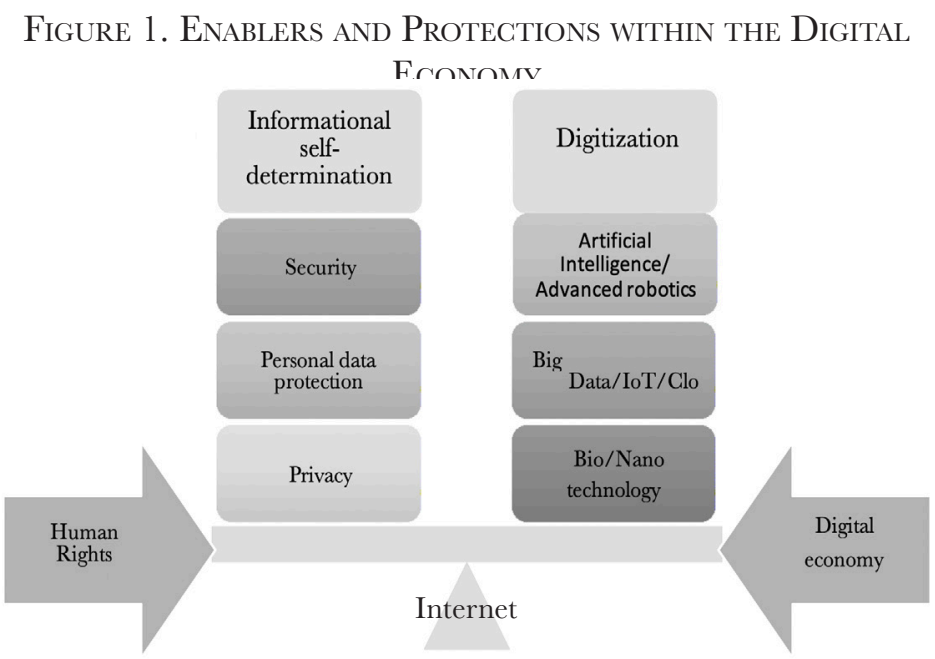

SOuRce: Prepared by the author.

\section{The Digitization of Everything and the Increasing Amount of Information Available}

The data and information that emerge from the digitalization of things have become the raw material for businesses and companies, a vital asset capable of creating a new form of economic value. ${ }^{35}$ The implementation of the

34 UNCTAD recognizes advanced robotics, artificial intelligence, the Internet of Things, cloud computing, big data analysis and three-dimensional (3D) printing, see United Nations Conference on Trade and Development (UNCTAD), Report on the Information Economy, 2017. Digitalization, Trade and Development, General Overview 2 (United Nations, New York) (2017). The OECD refers to " $3 \mathrm{D}$ printing, the Internet of Things, advanced robotics, new materials (based on bio or nano technology), as well as new processes (data driven production, artificial intelligence, synthetic biology)", see Organization for Economic Cooperation and Development (OECD), The Next Production Revolution: Implications for Governments and Business 14 (OECD Publishing, Paris) (2017). For the World Economic Forum, the "megatrends" and the technological engines of the fourth industrial revolution are: physical (autonomous vehicles, 3D printing, advanced robotics, new materials), digital (Internet of Things, blockchain) and biological (synthetic biology), see KLAUs Schwab, the Fourth Industrial Revolution 17 and ss. (World Economic Forum, Geneva) (2016).

35 Viktor Mayer-Schönberger \& Kenneth Gukier, Big Data. La revolución de los DATOS Masivos (Turner publicaciones S.A., Madrid) (2013). 
DIKW ${ }^{36}$ model for knowledge management and the extraction of data value - material premium data - can only be optimized in a coherent data ecosystem that includes software companies, SMEs, data sectors (private and public), researchers, academic institutions and capital providers. This data ecosystem will support the intensification of cooperation among the various groups of stakeholders to work towards achieving mutually reinforcing objectives.

Data economics ${ }^{37}$ measures the overall impact of the data market; that is, the market in which digital data are exchanged as products or services derived from raw data, in the economy as a whole. For the European Union, this data economy involves the generation, collection, storage, processing, distribution, analysis, processing, delivery and exploitation of the data that make digital technologies possible. ${ }^{38}$

\section{Artificial Intelligence (AI)}

This is characterized by automatic learning based on data and automated decision-making. In broad terms, AI is a collective term to identify "computer systems that can sense their environment, think, learn and act in response to what they perceive and their objectives". ${ }^{39}$ According to the study prepared by $\mathrm{PWC},{ }^{40}$ in 2030 the global GDP will be $14 \%$ higher as a result of artificial intelligence, which is equivalent to 157000 million USD.

\section{Big Data}

If we consider that every day more than 2.5 exabytes (equivalent to $1,000,000$ terabytes $)^{41}$ are generated in the world, we must consider that, as a result of the digitization of everything, we live in a world of enormous amounts of data. The amount does not define Big Data as it is only an exponential of the amount of information that is generated daily. From a technological point of view, we can understand Big Data as the information or group of data that cannot be stored or visualized with traditional tools due

36 Data, Information, Knowledge and Wisdom.

37 If we consider that $70 \%$ of the information is generated by us as users of various electronic devices, the foregoing would be equivalent to the "commodification of the self".

38 European Commission, Smart 2013/0063-Study on a "European Data Market" and Related Services 10, (IDC) (2016), https://ec.europa.eu/digital-single-market/en/news/smart20130063-study-european-data-market-and-related-services.

39 Anahiby Becerril \& Samuel Ortigoza Limón, supra note 26.

40 PWC, Sizing the prize. What's the real value of AI for your business and how can you capitalise?, (PWC) (2017), https://wrwr.pwc.com/gx/en/issues/analytics/assets/pwc-ai-analysis-sizing-the-prizereport.pdf.

41 In terms of bytes: Gigabyte $=10^{9}=1,000,000,000$. 
to its high volume, diversity and complexity. ${ }^{42}$ Big Data ${ }^{43}$ has become a new frontier for innovation, competitiveness and productivity. However, we must consider that data by itself is not valid if it is not converted into information, translated into knowledge and generated into wisdom. ${ }^{44}$ Data should lead to the development of actions, processes or even public policies. Big Data is presented as a challenge, but also it provides new opportunities for companies.

\section{Internet of Things (IoT)}

With a market value estimated to exceed one billion euros by 2020, the European Commission ${ }^{45}$ identifies the IoT as the next step in the digitalization of society and economy in which people and objects will be interconnected through communication networks that inform on their status and environment. The IoT is made up of a set of sensors ${ }^{46}$ that capture information about what happens in their environment. Due to the ubiquitous nature of the objects connected to IoT, it is estimated that by 2020 about 26 billion devices will connect to the Internet. These devices are a source of data collection that grows exponentially and, consequently, can be processed by Big Data systems.

\section{Cloud Computing}

The "cloud", as it is called, is a model that allows ubiquitous access conveniently and on demand network to a set of configurable computing resources, which can be provided quickly with minimal management or interaction with

42 Javier Puyol Montero, Aproximación jurídica y económica al Big Data 10 (Valencia, Ed. Tirant lo Blanch) (2015).

43 Regarding the use of Big Data, it should be noted that the large volume of information does not teach computers or devices to "think" as humans do. What it does is apply specific mathematical algorithms to these huge amounts of data to then infer probabilities.

44 This follows the DIKW model.

45 European Commission, Definition of a Research and Innovation Policy Leveraging Cloud Computing and Iot Combination. Final Report 10 (European Union) (2014), https:// ec.europa.eu/digital-single-market/en/news/definition-research-and-innovation-policy-leveraging-cloud-computing-and-iot-combination.

46 Radio frequency or RFID identification system consists of a tag with a microchip. Each tag has a unique code called an EPG (electronic product code). It also contains a reader (consisting of an antenna and a demodulator), which converts analog information into digital information. The converted information is sent through the network to a data center to be captured and in this way to cross-reference the data in a central computer. The EPC connects to the Internet by means of an IP address and a domain name; see Susana Navas Navarro \& Sandra Camacho Clavijo, Digital Market. Legal Principles and Rules 33 (Tirant lo Blanch, Valencia) (2016). 
the service provider. This model promotes availability with five essential characteristics, three service models and four implementation models. ${ }^{47}$ It is a model of ICT services in an ecosystem of technological resources that offers scalable, shared and on demand services in different modalities to different users through the Internet.

\section{Materials Based on "Bio-" or "Nano-" Technology}

Biotechnology and nanotechnology are both enabling technologies that have led to innovations in many industrial sectors, helping to determine broad ranges of economic and social impact. In accordance with ISO / TS 80004-1: 2015, ${ }^{48}$ nanotechnology is the application of scientific knowledge to manipulate and control matter at nanoscale, "as well as to make use of size and structure - dependent properties and phenomena, as distinct from those associated with an individual atoms or molecules or with bulk materials". Meanwhile, biotechnology constitutes the "manipulation ${ }^{49}$ of living organisms or their components to produce useful, usually commercial, products". ${ }^{50}$

All these technologies constitute platforms of innovation that permeate all economic sectors. They are possible since they are cultivated and improved through the digitalization of everything. However, the Internet did not succeed because its infrastructure became more secure, but in spite of its inherent insecurity. For the OECD, the nature of the technical vulnerabilities of the information systems interconnected through the Internet have not fundamentally changed. What has changed is that "society and the economy now depend on this fundamentally insecure environment". ${ }^{51}$

As data driven technologies, the issues surrounding privacy, personal data protection, information availability and the security of all of them are some of the main concerns in their being adopted by organizations and companies. With the digitalization of everything enormous volumes of data are generated to constantly feed Big Data, which is stored in the cloud. ${ }^{52}$ Hence, this

47 National Institute of Standards and Technology (NIST), the Nist Definition of Cloud Computing. Recommendations of the National Institute of Standards and Technology 2 (2011), https://nolpubs.nist.gov/nistpubs/Legacy/SP/nistspecialpublication800-145.pdf.

48 International Organization for Standardization/International Electrotechnical Commission, ISO/TS 80004-1:2015, https://wwweiso.org/obp/ui/\#iso:std:iso:ts:80004:-1:ed-2:v1:en.

49 This can be done through genetic engineering.

50 See Merriam-Webster Dictionary, https://wwwemerriam-webster.com/dictionary/biotechnology.

51 OCDE, Cybersecurity Policy Making at a Turning Point: Analysing a New Generation of National Cybersecurity Strategies for the Internet Economy 28, 29 (OCDE) (2012).

52 The storage of information in the cloud does not exclude the responsibility of organizations to protect both their regulation and reputation. In general, it is often the responsibility of user organizations in the cloud to ensure that personal data are protected and only used in accordance with the law. 
is a potential gold mine for cyberattacks and cybercriminals. In addition to cybersecurity risks of attacks, companies, governments and institutions must be aware of the vulnerabilities associated with ignorance due to breaches of security policies or lawsuits related to data breaches. If you do not have adequate processes, training and technological innovation in cybersecurity in the company, country or institution, you can be plunged in several problems, in addition to the loss of information, financial losses, damage to the brand and reputation, non-compliance with the law (along with fines), as well as the loss of competitive edge and trust.

\section{From Cyberspace to Cybersecurity}

\section{Cyberspace}

Cyberspace is a space of flows, a virtual space that grows daily with the interactions that are made through ICT. Called the fifth domain with the earth, sea, air and space, cyberspace is a virtual environment in which we carry out most of our daily activities. But unlike the other four domains, it needs permanent attention and human collaboration for it to operate.

Cyberspace is an electronic world, a global common space where people unite to exchange ideas, services and even friendship. ${ }^{53}$ It is a kind of nervous system that controls countries and the critical infrastructure that sustains them. Its proper functioning is essential for the economy and national security. ${ }^{54}$ It is a worldwide digital environment consisting of computer networks and telecommunications by which people communicate, interact, and are allowed to exercise their rights and freedoms in the same way they do in the physical world. ${ }^{55}$ Technically, ISO points out, cyberspace is "a complex environment resulting from the interaction of people, software and services on the Internet through technological devices and networks connected to it, which does not exist in any physical form". The definition of cyberspace is very important to understand what is to be protected. Therefore, there is still no approved concept for it.

Regardless of its definition, cyberspace is the basis by which e-commerce is carried out, as well as the foundation of the digital economy. Consider the daily increase in the creation of services and products, in addition to the

53 Government of Canada, Canada's Cybersecurity Strategy. For a stronger and more prosperous Canada, (2010), https://wrere.publicsafety.gc.ca/cnt/rsrcs/pblctns/cbr-scrt-strtgy/index-en.aspx.

54 United States Government, Cyberspace Policy Review. Assuring a Trusted and Resilient Information and Communications Infrastructure, (2009), https://wrwre.dhs.gov/sites/default/files/publications/ Cyberspace_Policy_Review_final_o.pdf.

55 Gobierno de México, Estrategia Nacional de Ciberseguridad (2017), https://wrerw.gob.mx/cms/ uploads/attachment/file/271884/Estrategia_Nacional_Ciberse guridad.pdf. 
technologies that are developed in this space. Nowadays we add information of all kinds that we manage through this virtual flow and the services already connected to it (including critical infrastructure). This results in an increasing dependence on ICT. And to the extent that our dependence on new technologies increases, we become more vulnerable to them, ${ }^{56}$ for example we have smart devices, even clothes, and maybe we are not so much.

\section{Cybersecurity}

In May 2017, the WannaCry ransomware hit 150 countries and hundreds of thousands of systems, paralyzing healthcare, production facilities and telecommunications. In 2018, new hardware weaknesses were exposed, and massive data breaches were found: in India's Aadhaar. ${ }^{57}$ Considered the world's largest biometric identification system, it suffered breaches that compromised the data of 1,100 million registered citizens. Later that same year, in September, Facebook ${ }^{58}$ notified its users of the largest massive data breach it had ever suffered, which came to affect more than 50 million people. And we began 2019 with the "worst attack of computer hacking" Germany has experienced of documents, personal messages, mobile phone numbers, credit card information, addresses, and emails (among others), in this große Datenleck. Some of the victims are the German Chancellor and German President Frank-Walter Steinmeier, as well as political parties, journalists and celebrities, among others. Putting this into perspective, one might ask, why worry about the security of cyberspace? Why is it necessary to incorporate it into free trade agreements? In relation to the first question, if the digital economy, like electronic commerce and multiple activities of our daily lives, are currently based on the flow of data and information, we must consider the security of all the infrastructure that contains it. Our critical infrastructure is increasingly connected to the networks that make up said cyberspace. Our daily activities, from com-

56 Víctor Manuel Castrillón y Luna, \& Anahiby Becerril, infra 98.

57 Aadhaar is the database managed by the Unique Identification Authority of India (UIDAI). It provides the UIDAI with a random 12-digit number issued to the residents of India after their complying with the established verification process. In addition to personal and demographic data, it also contains biometric information (ten fingerprints, iris scan of both eyes and a facial photograph). According to the Government: "The Aadhaar identity platform is one of the key pillars of" digital India, "where every resident of the country has a unique identity. The Aadhaar program has already reached several milestones and is, by far, the largest biometric identification system in the world"; see Unique Identification Authority of India, "What is Aadhaar?", Government of India, https://uidai.gov.in/what-is-aadhaarhtml.

58 According to Facebook, the breach would have happened on the afternoon of September 25. The attackers exploited a feature in the Facebook code to gain access to user accounts and possibly take control of them; see Isaac Mike \& Frenkel, Sheera, "Facebook Security Breach Exposes accounts of 50 Million Users", The New York Times, September 28, 2018, https://wrwe.nytimes.com/2018/09/28/technology/facebook-hack-data-breach.html. 
munication to accessing information, work, health and education, are carried out at every moment in that cyberspace. In this way, the Internet and ICTs have become a critical resource in the development of electronic commerce and the digital economy, which has consequences for cybersecurity policies, one of the main ones of which is the adoption of strategies that address the issue of cybersecurity.

And what is cybersecurity? Cybersecurity will strive to deal with the security of this cyberspace. We can interpret the term according to the concepts given by the technical community and those established in national cybersecurity documents. However, we believe that the ITU's definition ${ }^{59}$ issued in Recommendation ITU-T X.1209 (12/2019) adequately explains the concept: "3.1.1 Cybersecurity [b-ITU-T X.1205]: Collection of tools, policies, security concepts, security safeguards, guidelines, risk management approaches, actions, training, best practices, assurance and technologies that can be used to protect the cyber environment ${ }^{60}$ and organization and user's assets".

Identifying as "assets" the "connected computing devices, the users, the services/applications, the communication systems, the multimedia communications, as well as all the information transmitted and/or stored in the cyberenvironment". ITU recognizes that cybersecurity ensures that the security properties of the organization's assets and users are achieved and maintained against the corresponding security risks in the cyber-environment. And refers to the following information properties: availability; integrity, which may include authenticity and non-repudiation; and confidentiality.

Due to its rapid growth in number and sophistication, cyber-attacks ${ }^{61}$ are positioned as a critical threat to national security and one of the greatest risk's nations face today. In its "Global Risks Report 2019", the WEF has recognized fraud or massive theft of data and cyber-attacks as two of the five main global risks that countries perceive. ${ }^{62}$ While in North America, the risk of

59 International Telecommunication Union (ITU), Rec. ITU-T X.1209 (12/2019), Capabilities and their context scenarios for cybersecurity information sharing and exchange, ITU-T X-Series Recommendations 1, (ITU) (2010).

60 ITU does not use the term cyberspace, but refers to the cyber environment to refer to "users, networks, devices, all software, processes, stored information circulating, applications, services and systems that are directly or indirectly connected to networks"; see International Telecommunication Union, ITU-T X.1205 https://wrereitu.int/rec/T-REC-X.1205200804-I/en.

61 Although there is no uniform term, we can understand cyber-attacks as: an attack that is perpetrated through cyberspace, aimed at the "use of a company, cyberspace, in order to interrupt, disable, destroy or control maliciously an information infrastructure or destroy the integrity of the data or steal controlled information"; see National Institute of Standards and Technology (NIST), Glossary of Key Information Security Terms (2013), https://nvlpubs.nist.gov/nistpubs/ir/2013/NIST.IR.7298r2.pdf.

62 In $4^{\text {th }}$ and $5^{\text {th }}$ place respectively, only preceded by 3 climate-related risks; see World Economic Forum, Global Risks Report 2019, http://www3.weforum.org/docs/WEF_GRR18_Report.pdf. 
cyber-attacks has surpassed terrorist attacks as the number one risk of greatest concern in doing business. ${ }^{63}$

As a consequence, governments in many countries have begun to develop strategies or laws and national cybersecurity policies to protect themselves against cyber threats, with a risk management vision that allows them to identify their vulnerabilities while trying to promote the benefits of a hyperconnected and cyber-enabled world. The development of national cybersecurity strategies has become a national policy priority in several countries. ${ }^{64}$ The NATO Cooperative Cyber Defense Center of Excellence has identified more than 50 countries that have published a cybersecurity strategy or national cybersecurity strategy where they define "what security means for their future national and economic security initiatives". 65

Cybersecurity strategies or national cybersecurity strategies (NCSS) involve action plans to facilitate the attainment of a national competitive advantage regarding cybersecurity. They constitute action plans designed to improve the security and resilience of national infrastructures and services. These documents articulate an approach to cybersecurity adapted to a specific national or legal context. In this sense, the implementation of the strategies must be accompanied by planning technological development, as well as generating skills and human capital to work for it.

Just as there is no single definition for cyberspace and cybersecurity, there is no single strategy that can be followed given the characteristics of each country. However, we can identify common themes, which in the end does not make us so different. These include cooperation (international and national), the protection of users' human rights and risk management.

\section{Cybersecurity in Free Trade Agreements}

Concerns about national security and trade policies are not new. However, given the electronic nature of international and national commercial transactions, the theme has acquired a new and urgent prominence, especially in more developed countries due to an increasingly growing link and dependence on ICT, its services and its infrastructure. Turning now to the specific context and considering the fact that most developed and developing economies have laws and regulations that restrict foreign direct investment (FDI) based on concerns related to national security or the loss of countries'

63 World Economic Forum, Global Risks Report 2018, http://www3.weforum.org/docs/WEF_ GRR18_Report.pdf.

64 Organización para la Cooperación y Desarrollo Económicos (OCDE), Cybersecurity Policy Making at a Turning Point. Analyzing a New Generation of National Cybersecurity Strategies for the Internet Economy 9 (OCDE) (2012).

65 See NATO Cooperative Cyber Defense Centre of Excellence, https://wrwre.ccdcoe.org/ cyber-security-strategy-documents.html. 
natural resources, what would be the equivalent for protection in cyberspace? Economic security deals with trade, production and finance. ${ }^{66}$ Although developed and developing countries ${ }^{67}$ have different points of view regarding economic security threats associated with cybersecurity, as mentioned above, there are common and global problems.

As technologies are being rapidly adopted by governments, individuals and organizations, ICTs are gaining importance in the national security equation. Allegations related to cybersecurity have given rise to various barriers to international trade and investment. Obstacles related to cybersecurity cover at least the following categories of concerns: political ${ }^{68}$ and economic ${ }^{69}$ espionage and information security of countries ${ }^{70}$ and citizens. ${ }^{71}$

In relation to e-commerce, a cybersecurity strategy should ensure that it does not become an obstacle or barrier to these electronic transactions. That is, just as there are trade barriers, which constitute restrictions imposed on the free flow of trade and investment, a cybersecurity-related barrier for international trade and investment is defined as "any problem related to real and perceived security risks in the cybernetic environment that directly or indirectly hinders the growth of international trade and investment". ${ }^{72}$

\section{Association of Southeast Asian Nations (ASEAN)}

In the case of the Association of Southeast Asian Nations, ${ }^{73}$ Chapter 1 of its Charter" establishes that one of its purposes is to "enhance peace, secu-

66 Mathias Albert, \& Barry Buzan, Securitization, sectors and functional differentiation. 42 SECURITy Dialogue 413, 425 (2011), http://journals.sagepub.com/doi/abs/10.1177/0967010611418710.

67 For Kshetri, the United States is concerned about the theft of IP and other problems associated with economic espionage. The BRICS states (Brazil, Russia, India, China and South Africa), on the other hand, have argued that developing countries' dependence on Western technologies is a threat to economic security; see Nir Kshetri, the QUest to Cyber SuPERIority. Cybersecurity Regulations, Frameworks and Strategies of Major Economies 13 (Springer) (2016).

68 While espionage practices between states are not new, ICT has made it easier, mass surveillance, between states, as well as between states and non-state actors towards citizens. Recall Edward Snowden's declarations on the practices of massive, illegal surveillance carried out by the U.S. government, a situation that even led to the UN Recommendation on "Privacy in the Digital Age".

69 One example is the theft of industrial secrets.

70 This focuses more on critical infrastructure and strategic information, national or public security, among others.

71 These include freedom of expression, access to information, privacy and protection of personal data, in addition to the exercise of other human rights on the Internet.

72 NIR KSHERI, supra note 5.

73 The ASEAN nations are Indonesia, Philippines, Malaysia, Singapore, Thailand, Vietnam, Brunei Darussalam, Cambodia, Laos and Myanmar. Papua New Guinea is an observer.

74 The Charter entered into force on December 15, 2008. The document codifies ASEAN 
rity and stability and further strengthen peace-oriented values of the region", through mutual cooperation. In 2013, ASEAN and Japan signed the "Joint Ministerial Declaration of the ASEAN and Japan Ministerial Policy Meeting on cooperation in cybersecurity", ${ }^{75}$ where in addition to recognizing the importance of a secure cyberspace as one of the "major drivers" of innovation, it is also essential in "promoting social and economic activities and strengthening ASEAN connectivity". ${ }^{76}$

\section{From TPP to CPTPP}

The Trans-Pacific Economic Cooperation Agreement, better known by its acronym TPP (Trans-Pacific Partnership), ${ }^{77}$ covered different aspects aimed at making trade more agile and simple, reducing costs and times for doing business, always under the protection of clear and precise rules for everyone. For Sigmond, the TPP incorporated commitments that did not exist in the previous Free Trade Agreements. For example, the author says, "the parties committed to have protection for consumers and stop unsolicited commercial messages. They also promoted the commitment to help small and medium-sized businesses". ${ }^{78}$

In January 2017, the U.S. Government decided to withdraw permanently as a signatory from the TPP negotiations in search of better conditions for its country. In response to this and in an effort to give effect to the treaty, on November 11,2017 , the trade representatives of the 11 remaining countries ${ }^{79}$ agreed on the Comprehensive and Progressive Agreement for Trans-Pacific Partnership (CPTPP). On January 23, 2018, the 11 countries participating in the CPTPP reached an agreement in Tokyo, Japan. This agreement incorporates some provisions contained in the TPP, while others were suspended. ${ }^{80}$

standards, laws and values, as well as creates a legal framework for the organization's institutions.

75 On that occasion, reference was made to the fact that the concept of "cybersecurity" would be understood according to the provisions of Recommendation ITU-T X.1205, which has been cited in this paper.

76 Asean-Japan, Foint Ministerial Statement of the Asean-Fapan Ministerial Policy Meeting on Cybersecurity Cooperation (2013), http://wrewasean.org/storage/images/Statement/final_joint_statement\%20 asean-japan\%20ministerial\%20policy\%20meeting.pdf.

77 The TPP was signed by 12 countries on February 4, 2016.

78 Karen Sigmond, El comercio electrónico en los tratados de libre comercio de México, Ius Revista del Instituto de Ciencias Jurídicas de Puebla, Jan-June 2018, 372.

79 These countries are Australia, Brunei Darussalam, Canada, Chile, Japan, Mexico, New Zealand, Malaysia, Peru, Singapore and Vietnam.

80 Gobierno de México, Tratado Integral y Progresista de Asociación Transpacifico, (2018), https:// wrere.gob.mx/tratado-de-asociacion-transpacifico\#que_es. 
The TPP contains a section on electronic commerce (Chapter 14), where, in addition to recognizing it as a driver for economic growth and opportunities, it recognizes the importance of frameworks that promote consumer confidence, as well as the need to avoid obstacles for its use and development (Article 14.2.1).81 This section was incorporated into the GPTPP.

Within its definitions, the Agreement identifies computer programs, texts, "image, sound recording or other product that is digitally encoded, produced for commercial sale or distribution and that can be transmitted electronically" as digital products. ${ }^{82}$ This definition, in accordance with the text of the Agreement, should not be understood to "reflect a Party's view on whether trade in digital products through electronic transmission should be categorized as trade in services or trade in goods". ${ }^{83}$

The Parties to the Agreement recognize the economic and social benefits derived from the protection of personal information ${ }^{84}$ of e-commerce users, which also improves consumer confidence (Article 14.8.1). To guarantee this protection, each Party undertakes to adopt or maintain a legal framework that encourages the protection of users' personal information, based on the principles and guidelines of the relevant organizations (Article 14.8.2). The purpose is to promote a secure framework that allows the cross-border transfer of information (including personal information) by electronic means when the business is carried out by a "covered person" (Article 14.11.2). It also refers to protection against unsolicited commercial electronic messages.

In addition the treaty establishes the duty of the Parties to maintain a legal framework that governs electronic transactions consistent with the principles of the Model Law of Electronic Commerce of UNCITRAL or with the United Nations Convention for the use of Electronic Communications in International Contracts (Article 14.5.1.).

Regarding the barriers to electronic commerce, the parties agreed to strive to: "a) avoid any unnecessary regulatory burden on electronic transactions; b) facilitate input by interested persons in the development of its legal framework for electronic transactions" (Article 14.5.2). The foregoing implies, on the one hand, not applying unnecessary barriers, and on the other, coopera-

81 The treaty refers to consumer safety and establishes the parties' obligation to adopt or, where appropriate, maintain laws that prohibit fraudulent and deceptive commercial practices that cause harm or potential harm to consumers who participate in the activities carried out online (Article 14.7.2).

82 Government of New Zealand, Comprehensive and Progressive Agreement for Trans-Pacific Partnership. Chapter 14 (2018), https://wrere.mfat.govt.nz/assets/Trans-Pacific-Partnership/Text/14.-Electronic-Commerce-Chapter.pdf.

83 Id.

84 For purposes of the CPTPP, personal information constitutes "any information, including, about an identified or identifiable natural person" (Article 14.1). 
tion among the multiple stakeholders in shaping the legal framework, which is in line with the multistakeholder model of Internet Governance.

Chapter 14 of the aforementioned CPTPP highlights a section on Cybersecurity, which is aimed at promoting cooperation between the contracting parties. In addition, the instrument refers to committing to the development of capacities of the national entities responsible for responding to computer security incidents, as well as to employ collaborative mechanisms for the identification and mitigation of malicious intrusions or the dissemination of malicious codes that affect the electronic networks of the Parties (Article 14.16).

Although it does not make a single reference to the concept of cybersecurity, the framework around the countries that make up this treaty is as follows.

\section{Table 1. Applicable Legislation on Gybersecurity by CPTPP Member Countries}

\begin{tabular}{|c|c|c|c|}
\hline & \multicolumn{2}{|c|}{ CPTPP countries with strategies or cybersecurity documents } & \multirow{2}{*}{$\begin{array}{c}\text { GCI Ranking } \\
\text { (global ranking/ } \\
\text { score) }\end{array}$} \\
\hline Country & Instruments & Cybersecurity Concept & \\
\hline Australia & $\begin{array}{l}\text { - National security and } \\
\text { defense strategy. } \\
\text { Strong and Secure: A Strate- } \\
\text { gy for Australia's National } \\
\text { Security (2013) } \\
\text { - } 2016 \text { Defense White } \\
\text { Paper. }\end{array}$ & $\begin{array}{l}\text { Measures relating to the } \\
\text { confidentiality, availability } \\
\text { and integrity of information } \\
\text { that is processed stored and } \\
\text { communicated by electronic } \\
\text { or similar means. }^{87}\end{array}$ & $10 / 0.890$ \\
\hline $\begin{array}{l}\text { Brunei } \\
\text { Darussalam }\end{array}$ & $\begin{array}{l}\text { Computer Misuse Act } \\
(2007)^{88}\end{array}$ & **89 & $64 / 0.624$ \\
\hline
\end{tabular}

85 The Global Cybersecurity Index (GCI) prepared by the International Telecommunication Union (ITU) within the framework of the Global Cybersecurity Agenda (GCA) measures the degree of each country's commitment to cybersecurity by using a series of individual indicators on legal, technical and organizational aspects, measures, capacity building and international cooperation efforts. The indicators are prepared on the basis of a survey that reviews laws, regulations, computer security incident response teams (CSIRT), national policies and strategies, standards, certifications, vocational training, awareness and alliances; see International Telecommunication Union (UIT), Global Cybersecurity Index 2018, https://wrere.itu.int/en/ ITU-D/Cybersecurity/Documents/draft-18-00706_Global-Cybersecurity-Index-EV5_print_2.pdf.

86 Government of Australia, Strong and Secure: A Strategy for Australia's National Security, 2013, https://wrew. files.ethz.ch/isn/167267/Australia\%20A\%20Strategy\%20for\%20National\%20Securit. $p d f$.

87 See Government of Australia, Cyber Security, https://www.staysmartonline.gov.au/glossary.

88 Computer Misuse Act, 2007, http://wrew.agc.gov.bn/AGC\%20Images/LOB/PDF/Computer\% 20Misuse.pdf.

89 It is still developing a framework for cybersecurity. 


\begin{tabular}{|c|c|c|c|}
\hline Canada & $\begin{array}{l}\text { - Canada's Cyber Security } \\
\text { Strategy: For a Stronger } \\
\text { and More Prosperous } \\
\text { Canada }(2010)^{90} \\
\text { - Action Plan 2010-2015 } \\
\text { for Canada's Cyber Secu- } \\
\text { rity Strategy (2013) } \\
\text { - Action Plan for Critical } \\
\text { Infrastructure 2014-2017 } \\
(2014)\end{array}$ & $\begin{array}{l}\text { Cyberspace is the electronic } \\
\text { world created by interconnec- } \\
\text { ted networks of information te- } \\
\text { chnology and the information } \\
\text { on those networks. It is a global } \\
\text { common where more than } \\
1.7 \text { billion people are linked } \\
\text { together to exchange ideas, } \\
\text { services and friendship } 91\end{array}$ & 9/0.892 \\
\hline Chile & $\begin{array}{l}\text { Política Nacional de Ci- } \\
\text { berseguridad }(2017)^{92}\end{array}$ & $\begin{array}{l}\text { Cybersecurity is a condition } \\
\text { characterized by a minimum } \\
\text { amount of risks to cyberspace, } \\
\text { understood as the set of physi- } \\
\text { cal, logical infrastructures and } \\
\text { human interactions that occur } \\
\text { there. }^{93}\end{array}$ & $88 / 0.438$ \\
\hline Japan & $\begin{array}{l}\text { National security and } \\
\text { defense strategies: } \\
\text { - Defense White Paper } \\
\text { Japan }(2015) \\
\text { - Cybersecurity Strategy- } \\
\text { Towards a World- } \\
\text { Leading, Resilient and } \\
\text { Vigorous Cyberspace } \\
(2013) \\
\text { - International Strategy } \\
\text { on Cybersecurity-j-Ini- } \\
\text { tiative for Cybersecurity } \\
(2013) \\
\text { - Cyber Security Strategy } \\
(2015)^{94}\end{array}$ & $\begin{array}{l}\text { Japan aims to construct a } \\
\text { "world-leading", "resilient" } \\
\text { and "vigorous" cyberspace, } \\
\text { and incorporate this cyberspa- } \\
\text { ce as a social system to realize } \\
\text { a "cybersecurity nation" as a } \\
\text { society that is strong against } \\
\text { cyber-attacks, full of innova- } \\
\text { tions and of which its people } \\
\text { will be proud. }\end{array}$ & $14 / 0.880$ \\
\hline
\end{tabular}

90 Government of Canada, Canada's Cyber Security Strategy. For a Stronger and More Prosperous Canada, 2010, https://wrerrepublicsafety.gc.ca/cnt/rsrcs/pblctns/cbr-scrt-strtgy/cbr-scrt-strtgy-eng.pdf.

91 In its strategy, reference is made to cyberspace.

92 See Government of Chile, Politica Nacional de Ciberseguridad (2017), http://ciberseguridad.inte rior.gob.cl/media/2017/05/PNCSS-CHILE-FEA.pdf.

93 "La ciberseguridad es una condición caracterizada por un mínimo de riesgos para el ciberespacio, entendido como el conjunto de infraestructuras físicas, lógicas y las interacciones humanas que allí ocurren". The concept states that, in accordance with international standards, the key attributes to be protected are "the confidentiality, integrity and availability of information", which in our opinion coincides with the definition of ITU on cybersecurity, $I d$.

94 Government of Japan, Cyber Security Strategy 2015, http://werwer.nisc.go.jp/active/kihon/pdf/ cs-senryaku.pdf.

95 See Compilation of Existing Cybersecurity and Information Security Related Definitions, Open Technology Institute New America-2013, https://werwenewamerica.org/cybersecurity-initiative/policypapers/compilation-of-existing-cybersecurity-and-information-security-related-definitions/. 


\begin{tabular}{|c|c|c|c|}
\hline Malaysia & $\begin{array}{l}\text { The National Cyber- } \\
\text { Security Policy (NCSP, } \\
\text { 2006) }\end{array}$ & $\begin{array}{l}\text { Vision: Malaysia's Critical Na- } \\
\text { tional Information Infrastruc- } \\
\text { tures will be secure, resilient } \\
\text { and self-reliant. Infused with a } \\
\text { culture of security, it will pro- } \\
\text { mote stability, social wellbeing } \\
\text { and wealth creation. }\end{array}$ & $8 / 0.893$ \\
\hline Mexico & $\begin{array}{l}\text { Estrategia Nacional de } \\
\text { Ciberseguridad (2017) }\end{array}$ & $\begin{array}{l}\text { Set of policies, controls, } \\
\text { procedures, risk management } \\
\text { methods and standards asso- } \\
\text { ciated with the protection of } \\
\text { society, government, economy } \\
\text { and national security in cybers- } \\
\text { pace and public telecommuni- } \\
\text { cation networks. }{ }^{97}\end{array}$ & $63 / 0.629^{98}$ \\
\hline New Zealand & $\begin{array}{l}\text { National security and } \\
\text { defense strategies: } \\
\text { - NewZealand's National } \\
\text { Security System (2011) } \\
\text { - Defense White Paper } \\
(2010) \\
\text { - New Zealand's } \\
\text { Cyber Security Strategy } 99 \\
(2015) \\
\text { - New Zealands } \\
\text { Cyber Security Strategy } \\
\text { Action Plan (2015) } \\
\text { - National Plan to Address } \\
\text { Cybercrime } \\
\text { (2015) }\end{array}$ & $\begin{array}{l}\text { The practice of making the } \\
\text { networks that constitute cyber } \\
\text { space as secure as possible } \\
\text { against intrusions, maintaining } \\
\text { confidentiality, availability } \\
\text { and integrity of information, } \\
\text { detecting intrusions and } \\
\text { incidents that do occur, and } \\
\text { responding to and recovering } \\
\text { from them. } 100\end{array}$ & $36 / 0.789^{101}$ \\
\hline
\end{tabular}

96 The National Cyber-Security Policy (NCSP), Malaysia, (2006), http://cnii.cybersecurity. my/main/ncsp/NCSP-Policy2.pdf.

97 "Conjunto de políticas, controles, procedimientos, métodos de gestión de riesgos y normas asociadas con la protección de la sociedad, gobierno, economía y seguridad nacional en el ciberespacio y las redes públicas de telecomunicación"; see Government of Mexico, Estrategia Nacional de Ciberseguridad 2017, https://wrwr.gob.mx/cms/uploads/attachment/file/271884/Estrate gia_Nacional_Ciberseguri dad.pdf.

98 In 2017, it ranked 38th (0.660).

99 New Zealand's Cyber Security Strategy 2015, https://wrww.dpmc.govt.nz/sites/default/files/201703/nz-cyber-security-strategy-december-2015.pdf.

100 See New Zealand's Cyber Security Strategy, 2011, https://wrere.dpmc.govt.nz/publications/ new-zealands-cyber-security-strategy-2011.

101 In 2018, New Zealand did not respond the Index questionnaire. However, in 2017 it was ranked 19th with a score of 0.718 . 


\begin{tabular}{|c|c|c|c|}
\hline Peru & $\begin{array}{l}\text {-Política de Seguridad } \\
\text { y Defensa Nacional } \\
(2017)^{102} \\
\text {-Decreto Supremo No } \\
\text { 066-2011-PCM. } \\
\text {-Agenda Digital Peruana } \\
2.0 \\
\text {-Decreto Legislativo 1141, } \\
\text { Decreto de Fortalecimien- } \\
\text { to y modernización del } \\
\text { Sistema-de Inteligencia } \\
\text { Nacional } \\
\text {-SINA y de la Dirección } \\
\text { Nacional de Inteligencia } \\
\text {-DINI }\end{array}$ & $\begin{array}{l}\text { Digital Security at the national } \\
\text { sphere is the level of confiden- } \\
\text { ce in the digital environment } \\
\text { resulting from managing and } \\
\text { implementing a set of proac- } \\
\text { tive and reactive measures } \\
\text { against risks that affect the se- } \\
\text { curity of individuals, economic } \\
\text { and social prosperity, national } \\
\text { security and national objectives } \\
\text { in that environment. It is based } \\
\text { on collaboration with actors } \\
\text { from the public sector, the } \\
\text { private sector and others who } \\
\text { support the implementation of } \\
\text { controls, actions and measu- } \\
\text { res. } 103\end{array}$ & $95 / 0.401$ \\
\hline Singapore & $\begin{array}{l}\text { - National Cyber Security } \\
\text { Masterplan } 2018 \text { (2013) } \\
\text { - Factsheet on National } \\
\text { Cyber Security Master- } \\
\text { plan } 2018 \\
\text { • Cyber security strategy } \\
(2016)^{104} \\
\text { - Cybersecurity Act (2017) }\end{array}$ & $\begin{array}{l}\text {...the security of a computer } \\
\text { or computer system against } \\
\text { unauthorized access or attack, } \\
\text { to preserve the availability } \\
\text { and integrity of the computer } \\
\text { or computer system, or the } \\
\text { confidentiality of information } \\
\text { stored or processed therein. }{ }^{105}\end{array}$ & $6 / 0.898^{106}$ \\
\hline
\end{tabular}

102 This document has a section called 4.2.14 Infrastructure to face attacks on information systems: Cybersecurity, where the commitment to the development of military and police skills stands out, with the purpose of "guaranteeing international peace and internal order"; through the integration of security-related systems to dissuade, confront, effectively combat and eliminate terrorist and drug trafficking organizations; see Presidencia de Perú, Decreto Supremo $\mathcal{N}^{\circ}$ 012-2017-DE. Decreto Supremo que aprueba la Política de Seguridad y Defensa Nacional, 2017, https://busquedas.elperuano.pe/normaslegales/decreto-supremo-que-aprueba-la-politica-de-seguridad-y-defen-decreto-supremo-n-012-2017-de-1600032-1/.

103 "La Seguridad Digital en el ámbito nacional es el estado de confianza en el entorno digital que resulta de la gestión y aplicación de un conjunto de medidas proactivas y reactivas frente a los riesgos que afectan la seguridad de las personas, la prosperidad económica y social, la seguridad nacional y los objetivos nacionales en dicho entorno. Se sustenta en la articulación con actores del sector público, sector privado y otros quienes apoyan en la implementación de controles, acciones y medidas"; see Presidencia de Perú, Decreto Supremo N No 050-2018-PCM por que se Aprueba la definición de Seguridad Digital en el Ámbito Nacional (2018), https://busquedas. elperuano.pe/download/url/aprueban-la-definicion-de-seguridad-digital-en-el-ambito-nac-decreto-supremon-050-2018-pcm-1647865-1.

104 Cyber security strategy, Singapore, (2016), https://wrerre.ccdcoe.org/sites/default/files/documents /SingaporeCybersecurity Strategy.pdf.

105 See Cybersecurity Bill 2017, Singapore, https://werere.csa.gov.sg/ /media/csa/cybersecurity_ bill/draft_cybersecurity_bill_2017.ashx? la=en.

106 In 2017, the IGC placed Singapore at number 1 with 0.925. 


\begin{tabular}{|l|l|l|l|}
\hline $\begin{array}{l}\text { Socialist } \\
\text { Republic of } \\
\text { Vietnam }\end{array}$ & $\begin{array}{l}\text { Law on Network Informa- } \\
\text { tion Security (2016) }\end{array}$ & $\begin{array}{l}\text { Network information secu- } \\
\text { rity means the protection of } \\
\text { network information and in- } \\
\text { formation systems against any } \\
\text { illegal access, use, disclosure, } \\
\text { interruption, amendment or } \\
\text { sabotage in order to ensure the } \\
\text { integrity, confidentiality and } \\
\text { availability of information. }\end{array}$ & $50 / 0.693$ \\
& & \\
\end{tabular}

SOURCE: Developed by the author.

\section{The North American Free Trade Agreement (NAFTA)}

For the purpose of establishing the basis for strong economic growth and greater prosperity for the countries that integrate it, in 1994 the North American Free Trade Agreement (NAFTA) entered into force between Canada, the United States ${ }^{109}$ and Mexico. In this way, one of the largest free trade zones in the world was created. On August 13, 2017, the rounds of NAFTA renegotiations began. Beyond the statements of the U.S. Government regarding the treaty, the 3 countries agreed that the treaty needed to be modernized.

The original NAFTA did not contain provisions on electronic commerce or cybersecurity. So, we are witnessing a new chapter in the commercial flow among the three nations, as well as new agreements about security, but this time, to safeguard cyberspace, which is common as well as global.

The USMCA has incorporated (among other provisions) Chapter 19 on Digital Trade, where several issues are addressed, including the principles on access and use of the Internet for digital commerce (Article 19.10), as well as the protection of personal data and the cross-border flow of information by electronic means (Article 19.11).

Regarding cybersecurity, which is addressed in the same chapter, the agreement focuses on international cooperation and capacity development among the 3 countries.

107 National Assembly of the Socialist Republic of Vietnam, Law on Network Information Security (2016), http://english.mic.gov.vn/Upload/VanBan/Law-on-Network-Information-Security-16-05-30. $p d f$.

$108 I d$.

109 In 2018, the CGI placed the United States (0.926) in 2nd place, below the United Kingdom (0.931). At the regional level, the index positions the United States as the $1^{\text {st }}$ with Canada in $2^{\text {nd }}$ place, followed by Uruguay $(0.681)$ and Mexico in 4th; see International Telecommunication Union (UIT), Global Cybersecurity Index 2018, https://wweritu.int/en/ITU-D/Cybersecurity/ Documents/draft-18-00706_Global-Cybersecurity-Index-EV5_print_2.pdf. 


\section{Table 2. Gomparison on Gybersecurity: GPTPP vs. NAFTA}

\begin{tabular}{|c|c|}
\hline \multicolumn{2}{|c|}{ Cybersecurity in Free Trade Agreements } \\
\hline СРТPP & US-Mexico-Canada Agreement \\
\hline $\begin{array}{l}\text { - It highlights a section on Cybersecurity ai- } \\
\text { med at promoting cooperation between the } \\
\text { contracting parties. } \\
\text { - In addition to committing to the develo- } \\
\text { pment of capacities of the national entities } \\
\text { responsible for responding to computer se- } \\
\text { curity incidents, as well as to employ colla- } \\
\text { borative mechanisms for the Identification } \\
\text { and mitigation of malicious intrusions or the } \\
\text { dissemination of malicious code that affect } \\
\text { the electronic networks of the Parties (Article } \\
\text { 14.16). }\end{array}$ & $\begin{array}{l}\text { - Cybersecurity (Article 19.15). The Parties } \\
\text { shall endeavor to: } \\
\text { a) build the capacities of their national en- } \\
\text { tities responsible for cybersecurity incident } \\
\text { response; and, } \\
\text { b) strengthen existing collaboration mecha- } \\
\text { nisms for cooperating to identify and miti- } \\
\text { gate malicious intrusions or dissemination } \\
\text { of malicious code that affect electronic net- } \\
\text { works, and use those mechanisms to swiftly } \\
\text { address cybersecurity incidents, as well as } \\
\text { for the sharing of information for awareness } \\
\text { and best practices. }\end{array}$ \\
\hline
\end{tabular}

SOURCE: Developed by the author

\section{Final Considerations}

Although some countries, like Mexico, have not adhered to or ratified international conventions on specific cybersecurity or cybercrime issues, like the Budapest Convention, it is through free trade agreements that cooperation, collaboration and international protection for the flow of information, products and services that circulate daily in cyberspace is being generated.

The threats and risks in cyberspace arise in a global common space. Networks are so interconnected ${ }^{110}$ that it can be difficult to limit the effects of an attack on a single part of the system without damaging others or interrupting it altogether. Our information assets flow together in cyberspace. Nowadays, sharing and safeguarding are critical to protecting public and private interests in the area of security, growth, human rights protection and economy.

In the physical world, there is no system that is $100 \%$ secure, and this also applies in cyberspace. We must consider that individuals, organizations, companies, governments and societies depend more on ICT every day. And although creating and implementing strategies or policies regarding cyberse-

110 This situation that has been a matter of concern in the UN General Assembly, which has recognized "that this growing technological interdependence is based on a complete network of essential information infrastructure components"; see Preamble Resolution A/ RES/58/199 dated January 30, 2004, https://wrew.itu.int/ITU-D/cyb/cybersecurity/docs/UN_ resolution_58_199.pdf. 
curity has an economic cost, the cost of inaction may be higher. In this sense, it pays to be prepared and resilient.

Regardless of its definition, cybersecurity must be implemented holistically, covering economic, social, educational, legal, police, technical, diplomatic, military and intelligence aspects. It must be based on risk management that respects human rights and is managed through a multistakeholder approach.

Concerns related to cybersecurity should strive not to give rise to barriers to electronic commerce and foreign investment. Although e-commerce requires a regulatory framework that guarantees legal certainty while protecting security of people who choose to use electronic means instead of conventional ones. These frameworks cannot impose barriers that prevent the development and economic growth that this kind of trade brings. For the OECD, national cybersecurity strategies must have two objectives: to promote economic and social prosperity, and to protect societies that depend on cyberspace against cyber threats. This must be done while preserving the openness of the Internet as a platform for innovation and new sources of growth.

The way in which cybersecurity is linked to national economic security has new forms and contexts. With the development of technologies that enable digital economy and encourage electronic commerce, the economic security associated with high technology is being recognized as a substantial source of national security.

Countries are increasingly dependent on the Internet to maintain their services, infrastructure and economies in cyberspace. Therefore, they should be the most concerned in keeping it safe. Thus, those responsible for drafting public policies face an immense task to follow the rapid pace of technological change in the midst of great uncertainty about what the future holes. ${ }^{11}$ In addition to considering issues like education and building digital skills, the labor market, science and innovation, competition, the development of technology, and commercial and industrial policy systems, countries should be responsible for the protection of their infrastructure (critic and strategic), which largely depends on national policies and priorities. But it must also be carried out with the cooperation of the various stakeholders, considering that most of the service providers are private companies. These issues are also of public interest since threats to cyberspace can affect countries and entire societies.

111 United Nations Conference on Trade and Development (UNCTAD), Informe sobre la economía de la información, 2017. Digitalización, comercio y desarrollo. Panorama general 6 (United Nations, New York/) (2017). 


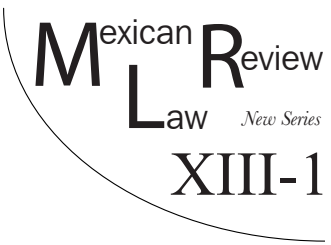

\title{
THE STATE OF EMERGENCY AS AN INSTRUMENT TO OVERCOME ORGANIZED CRIME AND VIGILANTES: A COMPARATIVE STUDY OF MICHOACÁN AND GUERRERO
}

\author{
Felipe Carlos Betancourt HigaredA* \\ Enrique Uribe ArZate**
}

\begin{abstract}
In the period of 2009-2014, organized crime subjected all kinds of political authorities and benefited from impunity throughout Mexico, especially in Michoacán and Guerrero. This circumstance provoked a grave constitutional crisis since these authorities were meaningfully overridden and were not able to properly enforce the rule of law in these regions. These phenomena brought about the rise of self-defense groups from local civil societies, as a desperate measure to protect their most fundamental rights from ruthless crime. However, this uprising deepened the constitutional crisis, already experienced in these regions due to the calamitous activities of criminal organisations, because it implied the complete absence of the Mexican state to restore legal order. The present article argues that a formal declaration of emergency by the Mexican President, with the official approval of the Mexican Congress, would have solved efficiently the constitutional crisis that Michoacan, Guerrero and other regions were going through in this period, and would have competently discouraged the expectations of the local people to relay on vigilantes as their last resort to guarantee their fundamental rights in the face of organized crime. This argument is based on archive research, testimonies of people uploaded in video documentaries, the Mexican Constitution, the International Human Rights Law, the doctrine of constitutional dictatorship of Clinton Rossiter, and the legal doctrine on balance and deliberation of Robert Alexy.
\end{abstract}

KEYwORDS: State of emergency, organized crime, vigilantes, Mexico, comparative study.

* Associate Professor at The Faculty of Law of Universidad Autónoma del Estado de México, Ciudad Universitaria S/N, Toluca, México, C.P. 50100. Email:fcbetancourt@uaemex.mx.

** Associate Professor at The Faculty of Law of Universidad Autónoma del Estado de México, Ciudad Universitaria S/N, Toluca, México, C.P. 50100. Email: euribea@uaemex.mx. 
RESUMEN: En el período de 2009 a 2014, el crimen organizado sometió a toda clase de autoridades políticas, y gozó de impunidad a lo largo y ancho de México, pero especialmente en Michoacán y Guerrero. Esta circunstancia ocasionó una seria crisis constitucional, ya que dichas autoridades habian sido sustancialmente anuladas y no podían hacer valer el Estado de Derecho en su respectivo ámbito de competencia. Esta realidad ocasionó el alzamiento de grupos de autodefensa ciudadana, a lo largo y ancho del país, ya que constituyó una medida desesperada de la sociedad civil para proteger sus derechos fundamentales, frente a la crueldad del crimen organizado. Sin embargo, este alzamiento agravó la crisis constitucional que ya estaban experimentando estas regiones geográficas, ya que evidenció la ausencia completa del Estado Mexicano para hacer valer el Estado de Derecho. El presente artículo argumenta que una declaración formal del Estado de Excepción, realizada por el presidente de la República y aprobada por el Congreso de la Unión, hubiera resuelto eficientemente la crisis constitucional que atravesaban estas regiones geográficas, y hubiera desalentado la formación de estos grupos de autodefensa ciudadana. Este argumento se fundamenta en una investigación con archivos y testimonios documentados en video, así como en la Constitución Política de los Estados Unidos Mexicanos, el Derecho Internacional de los Derechos Humanos, en la doctrina de Clinton Rossiter sobre la Dictadura Constitucional, en la de Evan F. Criddle y Evan Fox-Decent sobre el Estado Fiduciario, y en la doctrina de Robert Alexy sobre la ponderación de derechos fundamentales.

Palabras clave: Estado de excepción, crimen organizado, autodefensas, México, estudio comparado.

\section{Table of Contents}

I. INTRODUCTION

1. Legal Instruments that Control the State of Emergency in Mexico

2. The Doctrine on Constitutional Dictatorship and the State of Emergency.....

II. Research Methods ................................................................... 39

1. Empirical Dimension ........................................................ 39

2. Legal Dimension.................................................................. 41

III. The Gase of Michoacán ............................................................ 41

IV. The Gase of Guerrero........................................................... 49

V. Отнек Gases ............................................................................. 53

VI. Analysis of the Legal Feasibility of a Declaration of State of Emergency in Mexico 
VII. Proposing Typologies of Emergency and Vigilantes in Mexico.....

VIII. The Gurrent Debate on the State of Emergency in Michoacán, Guerrero and other Troubled Regions IN MeXico

IX. Final Gonsiderations.

\section{INTRODUCTION}

The academic literature on the state of emergency is vast, since this is an issue that has been researched by political theorists, political scientists and legal scholars alike, especially since the terrorist attacks on the Twin Towers in New York in 2001. ${ }^{1}$ Part of this academic literature deals with the conditions, imposed by the respective Constitutional Law and the International Human Rights Law (IHRL), which a declaration of state of emergency should formally fulfil in order to be considered valid. ${ }^{2}$

Conversely, other literature has focused on thoroughly understanding the principles that a declaration of state of emergency should respect in order to properly reconcile individual rights with community interests. ${ }^{3}$ On the other side, other authors have developed insightful theories on human rights in order to better explain the proper goals, scope and limits, which a state of emergency should hold, so that the relative state can guarantee effectively a 'secure and equal freedom' for the people. ${ }^{4}$

There are even other scholars who, based on comparative law, have proposed typologies of emergency powers classifying coherently the strategies in order to restore constitutional order, with the least human rights violations possible. ${ }^{5}$

Nevertheless, the common ground of the academic literature on the state of emergency is that scholarly works increasingly enrich the criteria to better distinguish an exceptional state of affairs from an ordinary one: No matter

1 Consider, for example, Bruce Ackerman's work: The Emergency Constitution, 121 YaLE L. REP., 1029, 1091 (2004).

2 See Clinton Rossiter, Constitutional Dictatorship, Crisis Government in the Modern Democracies (Routledge 2017) (1948). This scholar even advanced a systematized doctrine on the subject, which will be presented subsequently in this research article.

3 For example, Christop Schreur's work, Derogation of Human Rights in Situations of Public Emergency: The Experience of the European Convention of Human Rights, 9 YALE J. W. Pub. ORd. 113 (1982).

4 For example, Evan J. Criddle \& Evan Fox-Decent, Human Rights, Emergencies and the Rule of Law, 34 Hum. R. QuA. 39 (2012). Their conceptual framework will be described in more detail some pages ahead.

5 See John Ferejohn et al., The Law of Exception: A Typology of Emergency Powers, 2 (2) InT. Const. L. 210, 239 (2004). 
how serious this latter might seem, it must meet a specific benchmark to be deemed a public emergency. ${ }^{6}$

With this academic background, if we were based on the motto that a true state entails the satisfactory performance of all its institutions, as well as the substantive accomplishment of their aims, we would question whether these conditions were or not actually present in specific regions of Mexico, in the period of 2009-2014, and we would also doubt that the constitutional rule of law was indeed enforced then, throughout the Mexican territory.

This inquiry stems from the fact that, in this period, organized crime increasingly committed unlawful actions against the very same Mexican state, which were aimed at weakening it as much as possible to subdue it and prevent the constitutional enforcement of the rule of law, thus leading, step by step, specific regions of Mexico to a de facto state of emergency.

Still, how could we understand a state of emergency? It could be understood as that situation in which the (constitutional) rule of law is not appropriate, solid or powerful enough to solve a circumstance that threatens the viability of the state. This state of affairs could result from a natural disaster, state of war, internal revolt or any other circumstance that excels the standard power of the state to be solved through ordinary means. ${ }^{7}$

\section{Legal Instruments that Control the State of Emergency in Mexico}

At the national level in Mexico, the declaration of state of emergency is specifically regulated by the Article 29 of the Mexican Constitution, which establishes an explicit procedure for this declaration to be validly made. In this procedure, a plurality of authorities participate, ${ }^{8}$ with the goal of keeping in check this extraordinary power that is granted, in the first place, to the Mexican President. This declaration could include two kinds of actions to surmount the specific emergency: a) the suspension of constitutional guarantees, and b) the enactment of special laws to overcome it.

Nevertheless, this declaration could be challenged through a constitutional trial (Fuicio Constitucional), and the derived judicial review would permit the Supreme Court of Justice of the Nation (SCJN, Suprema Corte de Fusticia de la Nación) to reflect on both the procedural and the substantial aspects of the

6 For example, Stephen Humphreys, Legalizing Lawlessness: on Giorgio Agamben's State of Exception, 17 (3) Eur. J. INT. L. 677 (2006), develops and explains thoroughly the different schools of thought on this subject.

7 See David Dyzenhous, Schmitt vs. Dicey: Are States of Emergency Inside or Outside the Legal Order, 27 Card. L. Rev. 2005, 2007 (2005).

8 The President cannot declare the state of emergency without the explicit approval of the Mexican Congress or of the Permanent Commission of this Congress. Conversely, the Mexican Supreme Court of Justice (SCJN) authorizes the decrees enacted during the emergency period, once this Court reviews their conformity to the Mexican Constitution. 
suspension of constitutional guarantees, so that it fully adheres to what is commanded by the Mexican Constitution.

On the other hand, the International Covenant on Civil and Political Rights (ICCPR) has established several restrictions to any state that intends to suspend constitutional guarantees and enact emergency laws to overcome a distress situation. These restrictions are mainly aimed at protecting the human rights and at impeding the abuse of any state when dealing with an emergency. ${ }^{9}$

Additionally, the American Convention on Human Rights (ACHR) explicitly forbids that some constitutional guarantees could be suspended, no matter the seriousness of the emergency that a state confronts. ${ }^{10}$ Furthermore, the formal declaration of a state of emergency should comply with the following requirements to become valid: a) competent subject, ${ }^{11}$ b) valid cause, ${ }^{12}$ c) object, ${ }^{13} d$ ) proper notice, ${ }^{14}$ and $e$ ) conduct. ${ }^{15}$

9 See Claudio Grossman, A Framework for the Examination of States of Emergency under the American Convention on Human Rights, 43 Am. Univ. Int. L. Rev. 1, (1986).

10 The rights that cannot be suspended, in accordance with the ACHR, are the following: a) the right to a legal personality, $b$ ) the right to life, $c$ ) the right to personal integrity, $d$ ) the right of not being slave, $e$ ) the right to the legality and retroactivity of the Law applied, $f$ ) the right to freedom of conscience and religion, $g$ ) the right to a family, $h$ ) the right to a name, $i$ ) the right to nationality, $j$ ) the rights of children, and $k$ ) political rights.

11 See Claudio Grossman, A Framework for the Examination of States of Emergency under the American Convention on Human Rights, 43 Am. UnIv. InT. L. REv. 40, (1986): Competent subject means "the legal person or entity that possess the juridical capacity to declare the state of emergency," in the case of Mexico, only the President of the Republic with the approval of the Federal Congress, and the Supreme Court of Justice, can declare this state of emergency, partially or in the whole territory.

12 Valid cause is referred to those facts that "compel the subject to derogate temporarily from certain of its peace time human rights obligations". According to the ACHR, a valid cause for the declaration of emergency should meet three basic requirements: a) The cause should be based on a real or imminent event, b) The declared situation of emergency should be of exceptional gravity, c) the emergency should impact the continued viability of the organized community. Claudio Grossman, A Framework for the Examination of States of Emergency Under the American Convention on Human Rights, 43 Am. UnIV. InT. L. REv. 41, (1986).

13 Object means the "State's obligation to fully protect and promote each of the rights guaranteed by the Convention" in this case, the ACHR. Claudio Grossman, A Framework for the Examination of States of Emergency under the American Convention on Human Rights, 43 Am. UNIV. INT. L. REV. 41, (1986).

14 Proper notice signifies that the "emergency provisions must provide the country's inhabitants a reasonable guide for conduct... and be published in sufficient detail". This proper notice should also a) "explicitly designate those rights guaranteed by the Convention" that would be suspended, b) describe the "circumstances that require the suspension" of specific human rights, and $c$ ) establish "the exact date for the termination of such suspension". Claudio Grossman, A Framework for the Examination of States of Emergency under the American Convention on Human Rights, 43 Am. UnIV. InT. L. Rev. 47, 48, (1986).

15 This requirement implies that any state is necessarily limited in the suppression of hu- 
On top of these requirements, there are more derived from the ACHR, which control the suspension of human rights during an emergency: a) necessity, ${ }^{16}$ b) temporality, ${ }^{17}$ c) proportionality, ${ }^{18}$ d) non-discrimination, ${ }^{19}$ e) compatibility with other international obligations, ${ }^{20}$ and f) adherence to domestic law. ${ }^{21}$

As it was stated above, these restrictions established by different instruments of the International Human Rights Law are aimed mainly at preventing any state from misusing emergency powers. This goal could be understandable in the case of Mexico, since, given the current weakness of its rule of law, a suspension of human rights could be implemented to achieve other policy aims, instead of seeking to overcome the relative public emergency. ${ }^{22}$

On the other hand, these international legal instruments can enhance the "ex post" controls of a formal declaration of state of emergency in our coun-

man rights, and that it is obliged to prevent possible abuses, and guarantee investigation and punishment of authorities responsible for the violation of human rights, during the period of emergency. Claudio Grossman, A Framework for the Examination of States of Emergency under the American Convention on Human Rights, 43 Am. UnIv. Int. L. Rev. 48, 49, (1986).

16 Necessity involves that there must be a serious "assessment of the actual need for each individual derogation of rights", by the respective state, to overcome the emergency and restore the constitutional order. Claudio Grossman, A Framework for the Examination of States of Emergency under the American Convention on Human Rights, 43 Am. UnIv. InT. L. Rev. 51, (1986).

17 Temporality connotes that the suspension of human rights should take place "for the time strictly required by the exigencies of the situation." Claudio Grossman, A Framework for the Examination of States of Emergency under the American Convention on Human Rights, 43 AM. UNIV. INT. L. REv. 51 (1986).

18 Proportionality means that the suspension of human rights should be carried out "to the extent... strictly required" to overcome the emergency and restore the constitutional order. Claudio Grossman, A Framework for the Examination of States of Emergency under the American Convention on Human Rights, 43 Am. UnIv. InT. L. REv. 52 (1986).

19 Non-discrimination implies that the suspension of human rights should exclude "any form of discriminatory treatment based on race, religion, sex, ethnic group, political belief or other quality". Claudio Grossman, A Framework for the Examination of States of Emergency under the American Convention on Human Rights, 43 Am. UnIV. InT. L. Rev. 52 (1986).

20 Compatible with other international obligations signifies that any state should review if the suspension of specific human rights does not oppose previous international commitments undertaken by such state. Claudio Grossman, A Framework for the Examination of States of Emergency under the American Convention on Human Rights, 43 Am. Univ. Int. L. Rev. 52, 53 (1986).

21 Finally, adherence to domestic law indicates that the suspension of human rights should also be coherent with the Constitutional normativity enforced by the respective state. Claudio Grossman, A Framework for the Examination of States of Emergency under the American Convention on Human Rights, 43 Am. UnIv. Int. L. Rev. 53 (1986).

22 For example, Christop Schreur, Derogation of Human Rights in Situations of Public Emergency: The Experience of the European Convention of Human Rights, 9, Yale J. W. Pub. Ord. 113 (1982) argues that this is the most dangerous use that could be made of a formal declaration of state of emergency and derogation of non-peremptory human rights norms, by any constitutional state. 
try, so that the Mexican state might become more answerable to the international community of its right use or misuse. ${ }^{23}$

\section{The Doctrine on Constitutional Dictatorship and the State of Emergency}

Nonetheless, the doctrine on constitutional dictatorship advanced by Clinton Rossiter has established eleven necessary conditions so that a declaration of state of emergency fulfils its aim of preserving the constitutional order. ${ }^{24}$ These eleven conditions are also aimed at impeding the abuse of emergency powers, by any constitutional dictator, who may use them to boost a longterm authoritarian regime, by means of the very same distress that his own country could be enduring.

23 See Richard B. Lilich, The Paris Minimum Standards of Human Rights Norms in a State of Emergency, 79 (4), Am. J. Const. L. 1074 (1985). This legal scholar affirmed that "at the regional or international level, every declaration of emergency by a state party to a regional or international human rights treaty shall be subject to such judicial or other review as the terms of the particular may provide; while, at the national level, such power of review shall be exercised in terms of the constitution and legal tradition of the concerned".

24 These eleven conditions are the following:

a) "No general regime or particular institution of constituted dictatorship should be initiated unless it is necessary to the preservation of the state and its constitutional order.

b) The decision to institute a constitutional dictatorship should never be in the hands of the men who will constitute the dictator.

c) No government should initiate a constitutional dictatorship without making specific provisions for its termination.

d) All uses of emergency powers and all readjustments in the organization of the government should be effected in pursuit of constitutional or legal requirements.

e) No dictatorial institution should be adopted, no right invaded, no regular procedure altered any more than is absolutely necessary for the conquest of the particular crisis. Certain it is that normal institutions ought to be declared unsuited to crisis conditions unless the unsuitability be painfully evident.

f) The measures adopted in the prosecution of a constitutional dictatorship should never be permanent in character or effect. Emergency powers are strictly conditioned by the purpose and this purpose is the restoration of normal conditions. The actions directed to this end should therefore be provisional.

g) The dictatorship should be carried on by persons representative of every part of the citizenry interested in the defense of the existing constitutional order.

h) Ultimate responsibility should be maintained for every action taken under constitutional dictatorship.

i) The decision to terminate a constitutional dictatorship should never be in the hands of the men who constitute the dictator.

j) No constitutional dictatorship should extend beyond the termination of the crisis for which it was instituted.

k) The termination of the crisis must be followed by as complete a return as possible to the political and governmental conditions existing prior to the initiation of the constitutional dictatorship". Clinton Rossiter, Constitutional Dictatorship, Grisis Government in the Modern Democracies XII-XIV (Routledge 2017) (1948). 
Based on this conceptual framework, it is possible to argue that, at some point, in the period of 2009-2014, some constitutional guarantees could have been suspended, so that the Mexican state would have worked out more energetically the distress that different regions were suffering due to the calamitous activity of organized crime.

The reality was that the constitutional rule of law in Mexico had been debilitated by organized crime, to such a degree, that it had become incapable of preserving the human rights of millions of people. In fact, the infringements to fundamental rights, carried out by organized crime across this country and in this period, were far more serious than any damage that Germany, Italy and Japan had brought about to this sovereign state during the Second World War, when Mexico declared its first state of emergency after the Mexican Revolution.

Nevertheless, Clinton Rossiter's doctrine on Constitutional Dictatorship is not the only conceptual framework that can support the convenience of a derogation of non-peremptory human rights norms, in those regions of Mexico where organized crime has caused calamities.

Another relevant normative theory on this subject is the legal doctrine that regards the state as fiduciary of the duty of protecting its people's basic rights. Based on this established position, the main duty of a sovereign state is to preserve, on behalf of all its subjects, "secure and equal freedom for all", whatever the means might be necessary for this end goal. ${ }^{25}$

Consequently, in accordance with this conceptual framework, emergency powers should be esteemed as the last resort of a sovereign state in order to fulfill this mission, which entails not only the achievement of "secure and equal freedom for all", but also the guaranty of enjoyment of all human rights. ${ }^{26}$

Moreover, based on this insightful theoretical perspective, the formal suspension of non-peremptory human rights during a public emergency may not only be a legitimate faculty of a sovereign state, but also its grave duty so that the human security of all its citizens may be completely assured. ${ }^{27}$

25 See Evan J. Criddle \& Evan Fox-Decent, Human Rights, Emergencies and The Rule of Law, 34 Hum. R. QUART. 42 (2012). To reinforce this argument, both scholars affirm that "under the fiduciary model, states would be permitted to derogate from their human rights obligations where necessary to address regional instability that threatened the state's capacity to maintain legal order".

26 See Evan J. Criddle \& Evan Fox-Decent, Human Rights, Emergencies and The Rule of Law, 34 Hum. R. QuART. 54 (2012). Moreover, these authors argue that "all public powers are constrained and constituted by the state's fiduciary duty to respect, protect and fulfill human rights".

27 See Evan J. Criddle \& Evan Fox-Decent, Human Rights, Emergencies and The Rule of Law, 34 Hum. R. QuART. 60 (2012). One of the ways these scholars framed this argument was: "under the fiduciary theory, a state may not declare an emergency unless exigent circumstances frustrate the state's ability to provide secure and equal freedom through reliance on the laws, practices, or procedures that apply outside an emergency". 


\section{Research Methods}

Since the main argument of the present article is that from 2009 to 2014 Michoacán, Guerrero and other regions of Mexico went through such a constitutional crisis that a formal declaration of emergency would have been completely justified, we will proceed to describe its research methodology in order to test and prove this argument.

\section{Empirical Dimension}

The empirical dimension of this inquiry was researched mainly through qualitative methodology, i.e. case study research based on journalistic archives and testimonies uploaded in video documentaries. Conversely, official quantitative data were used to describe thoroughly the social and economic context of Michoacán and Guerrero, in the period of study.

Notwithstanding, the Mexican official legal concept of emergency was approached from a set theoretical point of view, ${ }^{28}$ which implied that each of its attributes constituted a sufficient condition for the acknowledgement of an emergency.

Based on the Article 29 of the Mexican Constitution, in this legal concept in the period of 2009 to 2014 three attributes (or sufficient conditions, from an established theoretical perspective) would have been necessary in Michoacán, Guerrero and other entities, for an emergency to have been validly recognized: a) serious detriment to public peace, b) pressing threat, and c) dangerous conflict. ${ }^{29}$

A serious detriment to public peace could be defined as that situation in which people cannot perform their ordinary activities, do not benefit from human development, and are constrained in their exercise of civil and political liberties due to social strife. ${ }^{30}$ Thus the main features of this condition could be summarized in the following terms: $a$ ) abnormality, $b$ ) deterioration of human development, and c) constraint in the practice of liberties.

On the other hand, a pressing threat (grave peligro), could be defined as that circumstance in which fundamental rights are constantly menaced by an extraordinary incident, and this threat can put in serious jeopardy these rights,

28 "This is because membership in the concept is determined not just by the choice of attributes and indicators, but also by the role defined for each attribute or indicator (necessary/sufficient)". John Gerring, Social Science Methodology. A Unified Framework 165 (Cambridge University Press 2014).

29 These terms were translated directly from the official text of the Article 29 of the Mexican Constitution: a) Perturbación grave de la paz pública, b) grave peligro and c) grave conflicto.

30 This, and the following definitions of the specific attributes of the legal concept of emergency in Mexico, are elaborated by the authors of this article, since their meaning has not been clarified completely by an official legal interpretation. 
in case of being too lengthy; thus the elements of this attribute could be summarized in the following terms: a) threat in strict sense, b) fundamental rights, and $c$ ) the unsustainability of the predicament.

Finally, a dangerous conflict (grave conflicto) could be defined as that context in which people are so polarized by their own interests that the law of violence prevails. Thus, the components of this sufficient condition could be summarized as follows: a) polarization, b) extreme individualism, and c) violence.

As it can be noticed, the methodological challenge in this article consisted in defining consistently each of the attributes contained in the legal concept of emergency, and find primary data that could operationalize them, so that one could be able to validly and reliably describe the degree of distress experienced in Michoacán, Guerrero, and other regions of Mexico, in the period of 2009 to 2014.

The main goal of the empirical inquiry of this article is to test a descriptive argument on the social context of Michoacán, Guerrero and other regions of Mexico, the primary data, chosen for this purpose, will, first and foremost, serve to describe with detail the situation that each case study underwent, and measure the distress that Michoacán, Guerrero and other regions in Mexico endured throughout the period studied.

Specially relevant in this research were the data that could inform us about two crucial manifestations of the constitutional crisis suffered in Michoacán, Guerrero and other regions, which had been caused by organized crime: a) the degree of subjection of authorities and common people to organized crime and $b$ ) the degree of replacement of the constitutional judicial system, by a "civic" one, in order to overcome this crime.

However, the empirical dimension of the present research was not exhausted with describing the emergency that Michoacán, Guerrero and other regions of Mexico faced throughout the period of 2009-2014, but it also included the task of describing the main features of their corresponding vigilante groups.

For this purpose, in the present research synthetic arguments will be used to classify self-defense groups in Michoacán, Guerrero and other regions, consistent with their observed peculiarities through primary data qualitatively analysed, and then a simple typology of these groups will be proposed based on their observed features.

Furthermore, to deeply understand the social and economic context of Michoacán and Guerrero in the period of study, this article correlates the presence of organized crime with other social variables in these states, such as their extent of social scarcities and their degree of schooling backwardness.

The population under study in this research was constituted by all the vigilante groups that appeared from 2009 to 2014 in Mexico, the sample was formed by the vigilante forces of Michoacán, Guerrero and other regions that rose in that period, and the units of analysis were the specific vigilante 
groups that displayed cohesive strategies in the specific regions of study. Finally, the observations on these vigilante groups were carried out through journalistic archives and testimonies uploaded in video documentaries.

Conversely, the journalistic articles and the testimonies uploaded in video documentaries were analysed qualitatively, through descriptive, magnitude, structural, values, evaluation, and versus coding. ${ }^{31}$ These types of coding procedures allowed the authors to possess a more objective system to interpret the degree of social distress endured in Michoacán, Guerrero and other regions of Mexico, in the period of 2009 to 2014.

First and foremost, descriptive coding granted us the opportunity to identify the types of serious crimes that common people reported having suffered from organized crime. Secondly, magnitude coding allowed us, by assigning an alphanumeric character to the descriptive code previously allocated, to recognize the intensity of these crimes.

On the other hand, structural coding was carried out to describe people's interpretation of the gravity of the situation they were suffering, through the response of the following questions: a) Do they think that it is important to replace the constitutional judicial system to promote and defend their fundamental rights? b) Do they think that there is no other way left for them than self-defense, to protect their fundamental rights from organized crime? c) Do they think that the Mexican constitutional rule of law does not preserve sufficiently their basic human rights?

On the other hand, through values coding it was possible to interpret the value system that vigilantes possessed when they rose against organized crime. Finally, versus coding permitted us to elucidate if people approached their own fight against organized crime as a ruthless war.

\section{Legal Dimension}

In terms of the legal methods applied, the authors basically intended to interpret its cases studies in accordance with the legal criteria established in Article 29 of the Mexican Constitution, in the legal doctrines on constitutional dictatorship, and balance and deliberation, and in the relevant instruments of the IHRL, in order to discern if a suspension of constitutional guarantees and the enactment of emergency laws could have been done validly in these cases.

\section{The Gase of Michoacán}

At the beginning of the period of 2009-2014, self-defense groups rose mainly in the region of Tierra Caliente, in the west and south west of this state, in the

31 See Johnny Saldaña, The Coding Manual for Qualitative Researchers 83, 122 (Sage 2013). 
municipalities that bordered the Pacific Ocean and the states of Jalisco and Guerrero (see Map 1). ${ }^{32}$

\section{Map 1. Municipalities of Michoacán with Self-Defense Groups (2014)}

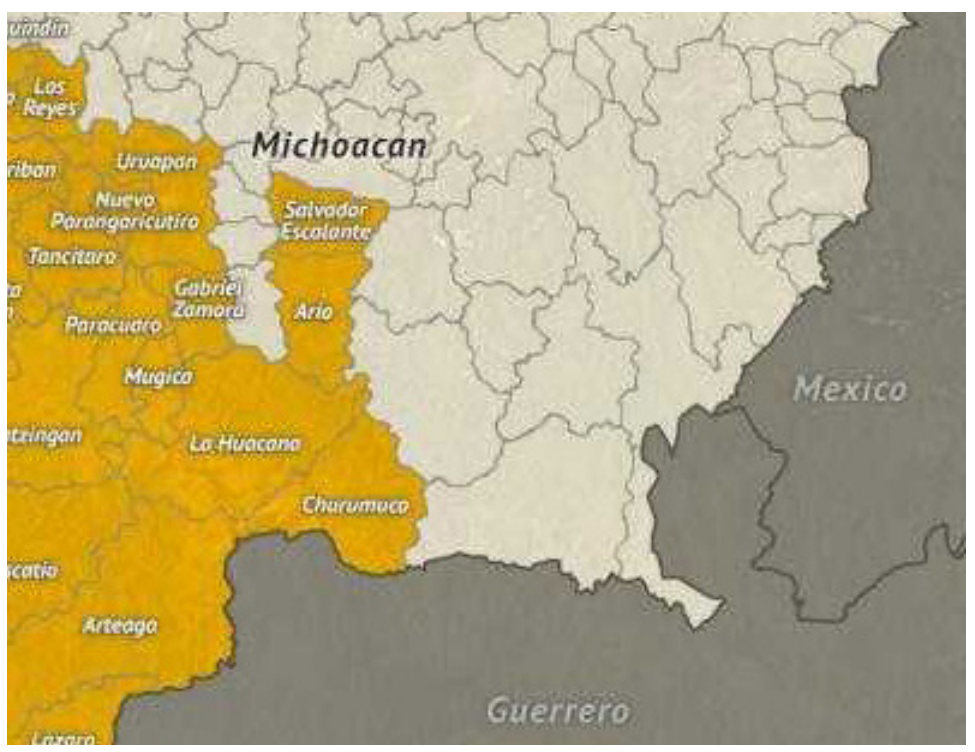

Source: Juan Velediaz. ${ }^{33}$

The main operating criminal organisation in Michoacán, at that time, was the Knights Templar (Caballeros Templarios), which had harassed local communities and seriously damaged the environment. ${ }^{34}$ Indeed, organized crime in the state of Michoacán posed a problem for the sustainable development of this region, since their members had carried out the irrational exploitation of natural resources. This destructive context triggered the formation of vigilante groups across the Tierra Caliente region of Michoacán.

32 These were the main municipalities that witnessed the rise of self-defense groups: Aquila, Coahuayana, Chinicuila, Coalcoman, Aguililla, Apatzingán, Tumbiscatio, Arteaga, Lázaro Cárdenas, La Huacana, Churumuco, Cherán, Tepalcatepec, Buenavista Tomatlán, Parácuaro, Múgica, Tancítaro, Perimba, Cotïa, Tinguindin, Los Reyes, Uruapán, Nuevo Parangaricutiro, Ario de Rosales, Salvador Escalante, Gabriel Zamora.

33 Juan Velediaz, El nuevo mapa de los Autodefensas, Estado Mayor.mx (April 21, 2014), http://wrwestadomayor.mx/41754.

34 See Alberto Torres, Pueblo Purépecha se levanta contra criminales en Cherán, El Universal, 4 May, 2011. People in Cherán were tired of murders, extortions, abductions, forced disappearances, and the deforestation of their land since 2008. 
As a premonition of the formation of these groups, local people started to build barricades to protect their communities from the Knights Templar. ${ }^{35}$ The devastating reality was that this drug-cartel had committed horrendous crimes against common people, ranging from cruel economic extortion to the rape and murder of wives and daughters of members of these vigilante groups. ${ }^{36}$

Unfortunately, the Knights Templar had subjected and paralyzed all kinds of public authorities (executive, judicial and legislative) in the state of Michoacán, by corruption or repression, clearing the path, in this way, to commit the worse possible crimes against common people: Extortions, abductions, rapes, property thefts, murders, psychological terrorism, and more. ${ }^{37}$

On the other hand, the constitutional judicial system could not guarantee a fair trial to the victims of this criminal organisation, because it was so corrupted that the enforcement of the law was manipulated against ordinary people and in favour of criminals. ${ }^{38}$

Furthermore, local people possessed evidence that many policemen and public authorities belonged to the workforce of this criminal organisation, so they could not benefit from any assurance or incentive, whatsoever, to collaborate with these authorities to prosecute and judge its members. ${ }^{39}$

The worst was that organized crime had replaced the Mexican state in taxing the chain of the economic activity of Michoacán and had threatened common people with execution, should they not agree to surrender to their extractive requests. ${ }^{40}$

35 At the beginning of April 2011, "local people in Cherán imposed martial law and closed streets with trunks, stones, bonfires and cars. The squads were formed by kids, women and men armed with sticks, stones, tubes and machetes" to protect their community from the intrusion of the Knights Templar. See Alberto Torres, Pueblo Purépecha se levanta contra criminales en Cherán, El Universal, 4 May, 2011.

36 In words of José Manuel Mireles Valverde, leader of vigilante groups in Michoacán, the kidnapping, rapes and murder of wives and daughters were the main factor that triggered the rise of these groups. See Me gusta leer México, Todos somos Autodefensas, de José Manuel Mireles en FIL Guadalajara 2017, Youtube (Dec. 5, 2017), https:/ / wrwereyoutube.com/watch? $=$ =thhHQ2MEPYA.

37 At the very beginning of their rise in Michoacán, vigilante groups used to surrender members of organized crime to prosecutorial authorities, but they eventually became disappointed, because they realised in time that the criminals they had surrendered to these authorities were released shortly afterwards. See Red Noticiero, Caballeros Templarios en Michoacán: Testimonio Autodefensa Ciudadana, Youtube (June 11, 2013), https://wrerc:youtube.com/watch?v $=7 R$ 6zUlX7Q1UG $t=682 s$.

38 See Id.

39 See Red Noticiero, Cártel Falisco Nueva Generación responde a "La Tuta" lider de los Caballeros Templarios, Youtube (May 30, 2013), https://wrerreyoutube.com/watch?v $=0 X U g K R F O 3 e$ Q. For example, in this documentary, the names of several policemen and prosecutorial authorities are mentioned as accomplices of the Knights Templar in Michoacán and Guerrero.

40 See Al Jazeera America, Mexico's Vigilante State-Fault Lines, Youtube (February 22, 2016), https://wrere:youtube.com/watch?v $=m m n M g D E p \_R 0 \Xi t=1011$ s. For example, in this documentary, 
Many people continued being disappeared without a subsequent criminal investigation, after they had refused to pay an extortion fee to the Knights Templar. ${ }^{41}$ Furthermore, there were many testimonies of people who had assured that the battle against this organisation was truly a matter of life or death, and that public authorities had been overwhelmed by this cartel and had not been able to fight it competently. ${ }^{42}$

Thus, clashes between vigilantes and political authorities unavoidably got under way, and they were exacerbated by the deep lack of trust local people had in the constitutional judicial system. Due to these unfortunate dynamics, people in Michoacán gradually took distance from the government, especially because they did not perceive that the Mexican state was doing enough to protect them against organized crime. ${ }^{43}$

On the contrary, federal and state authorities were more concerned on the rise of self-defense groups than on the causes of their emergence, so some news media focused on the official discourse that condemned their appearance more than on the civic discourse of these groups that had accused political authorities of being co-opted by and colluded with organized crime. ${ }^{44}$

Despite of claiming that their movement had been created against organized crime and not against the Mexican state, some print and broadcast news media started to approach vigilantes in Michoacán as dangerous outlaws, rather than a manifestation of the failure of the rule of law in Mexico. ${ }^{45}$

Nonetheless, some analysts approached the formation of these groups as a good opportunity to establish formal collaboration between civil society and state authorities with the aim to conquer organized crime, although the voices

there are personal stories that would normally correspond to a ruthless war between nations, for example, "they took away my ranches, shot my brother and killed eight of my workers".

41 See Jesús Lemus, Tierra sin Dios. Crónica del desgobierno y la guerra en MichoaCÁN 173 (Grijalbo 2015). This author even states that "Municipal authorities were subjected to the orders of the leaders of the «plaza»: If any of them liked a car or a house, or a woman, or a daughter, or the cattle, or the land or the property of any person, he just needed to send a squad to let the original owner know that it was now his property".

42 See, for example, Vanguardia Mx, Michoacán: Por qué surgen las autodefensas, Youtube (January 27, 2014), https://wrweyoutube.com/watch? $2=h C 9-s 2 H \_Z X s$.

43 See Redacción, Surgen 4 grupos de autodefensa en Michoacán, El UnIVERsal, March 10, 2013. Despite of their effort to rebuke the presence of vigilante groups in Michoacán, the official print news media in Mexico consistently reported the increasing rise of these groups in this state, due to the same cause: The harrying of the Knights Templar.

44 See Nurit Martínez Carballo, No hay justificación para autodefensa: CNDH, El UnIVERSAL, January 28, 2013. The Head of the GNDH, Raúl Plascencia, did not acknowledge self-defense against ruthless crime, as a basic human right that the state should preserve.

45 However, prestigious scholars, like Edgardo Buscaglia, sustained publicly that vigilante groups had emerged as consequence of the absence of the state and the weakness of the constitutional rule of law in México. See Doris Gómora, Advierte experto focos rojos por grupos paramilitares, El UnIVERsal, March 11, 2013. 
against the operation of these vigilantes increasingly opposed any form of collaboration with them. ${ }^{46}$

Unfortunately, the ruling party in Michoacán possessed a strong electoral interest in dismissing the presence of vigilante forces, and it spread in the public sphere, as a mechanism to protect its reputation, the view that this state truly lived under the rule of law. ${ }^{47}$ Therefore, not surprisingly, some news media highlighted the disarmament of self-defense groups, in Michoacán, as a great triumph of the Mexican state. ${ }^{48}$

Furthermore, the CNDH (Comisión Nacional de Derechos Humanos) and other Human Rights Organisations publicly refuted the human right to self-defense against organized crime, even when this opposition was leaving people vulnerable to serious violations of their human rights. ${ }^{49}$

The public denial that Michoacán was experiencing tax despotism, territorial control and paralegal order in the hands of the Knights Templar, made seem cruel any claim that this state was truly living under the rule of law, especially when this claim came from human rights activists or public authorities who had been aware of what organized crime had been doing in this state.

However, and despite the attempt to reduce the impact of vigilante groups on the reputation of the state government of Michoacán, the PRI faced a state electoral battle in 2015 that eventually resulted in it losing the government of the state. ${ }^{50}$

After generally describing the events that led to the formation of vigilante groups in Michoacán, and after getting to know, in more detail, the distress that they experienced due to the calamitous activities of organized crime in their state, we are in a better position to learn if the hypothesis set up in Article 29 of the Mexican Constitution to suspend constitutional guarantees and declare the state of emergency was actually fulfilled in the period of 2009 to 2014 in this state.

46 Specially the voices, that supported the regime of Peña Nieto, felt awkward by the spread of the news of the failure of the rule of law in these regions. See Marcos Muédano, Fustificar la autodefensa es riesgoso: Naranjo, EL Universal, September 12, 2013.

47 Specially the Governor of Michoacán, Fausto Vallejo, was indeed extremely reluctant to publicly acknowledge the legitimacy of vigilantes. See Mariana León, Considera Vallejo a autodefensa tema "mediático", El Universal, March 22, 2013.

48 See Alberto Morales \& Juan Arvizu, Autodefensas no deben sustituir al Estado: Hurtado, EL Universal, April 29, 2014. In this note, there is not an acknowledgement of the profound motive of the rise of vigilantes and of the replacement of the constitutional judicial system: The protection of the most basic human rights from organized crime.

49 See Silvia Otero, CNDH alerta de proliferación de autodefensas en más estados, EL UNIVERSAL, February 6, 2013.

50 Not surprisingly, Silvano Aureoles Conejo (PRD), was elected new governor of Michoacán in 2015, defeating overwhelmingly the PRI in the corresponding state elections. 
Concerning a serious detriment to public peace, we could observe that Michoacán lived through an abnormal situation: Organized crime was controlling more and more the economic activities of common people through extortion, tax fees, kidnapping, exploitation of natural resources, among others, and this escalating control damaged grievously the standards of living in this state. ${ }^{51}$

Regarding a serious threat, its elements were indeed present in Michoacán in the period of 2009 to 2014, because the threat in strict sense was of such a great magnitude, that not only the lives, properties and freedom of common people were at risk because of frightful crimes, but it also became so unbearable that local people got desperate and were forced to form vigilante groups. This desperation of local people could be judged as a clear sign of the insupportable suffering they endured in this period.

Concerning a serious conflict, the extractive activities of organized crime, in this state, triggered such a severe confrontation between local people and criminal organisations, that their differences could only be solved by extremely violent methods: Both, polarisation and violence, could be observed in this case.

On the other hand, the distress in Michoacán was extremely grave and, to a certain extent, uncontrollable, because it was handled with modest social capital and it fought against a very powerful and ruthless criminal organisation.

One distinctive feature of self-defense groups in Michoacán was that they gathered around a strong leader, José Manuel Mireles Valverde, and was not based on a large civic association spread all through the state, as was the case of Guerrero. Apparently, organized crime could recruit young people more readily in mestizo municipalities than in indigenous ones like Cherán. ${ }^{52}$

As a matter of fact, the emergency in Cherán encouraged the enactment of indigenous law to neutralize more capably organized crime and triggered the replacement of the constitutional judicial system by the local indigenous one. Furthermore, customary law has encouraged the self-organisation of people, it has developed social capital and trust, and it has boosted the community spirit and the spread of democratic practices in the decision-making processes of this municipality. ${ }^{53}$

One of the most important peculiarities of the customary law of Cherán is that its principles encourage democratic practices and deals more with the common good of the municipality than with pursuing an orthodox criminal procedure. Moreover, it possesses a different view on the main aims of the penal system, probably because its context requires a different approach to the purpose and meaning of this system so as to achieve order and peace. In

\footnotetext{
51 See Red Noticiero, Caballeros Templarios en Michoacán: Testimonio Autodefensa Ciudadana, 2013.

52 See Redacción, Cherán: 5 años sin crimen ni partidos políticos, MiLenio, September 13, 2016.

53 See Comenta YT, El Ejemplo del Municipio Mexicano de Cherán, Youtube, (August 30, 2018), https://wrere:youtube.com/watch?v $=d H w K a o d n I f U$.
} 
few words, the customary law of Cherán deems justice and fairness in a more substantive than procedural way. ${ }^{54}$

On the other hand, although organized crime is a widespread social phenomenon in Mexico, its presence in Michoacán is correlated with extent social scarcities, low schooling, and poor human development.

The following descriptive data obtained from the Coneval (Consejo Nacional de Evaluación de la Politica de Desarrollo Social) of Mexico, can provide us a better picture of the hard social and economic environment that the people in Michoacán lived through in the period of 2009-2014.

\section{Table 1. Social Scarcities in Michoacán (2010-2014)}

\begin{tabular}{|l|c|c|c|}
\hline \multicolumn{3}{|c|}{ Indicators } & \multicolumn{3}{c|}{ Percentage } \\
\hline & 2010 & 2012 & 2014 \\
\hline Proverty & & & \\
People in proverty & 54.7 & 54.4 & 59.2 \\
People in moderate poverty & 41.2 & 39.9 & 45.2 \\
People in extreme poverty & 13.5 & 14.4 & 14.0 \\
People vulnerable due to social scarcities & 28.6 & 30.7 & 25.0 \\
People vulnerable due to income & 4.3 & 3.5 & 4.1 \\
Non poor and non-vulnerable people & 12.3 & 11.5 & 11.7 \\
\hline Social Deprivation & & & \\
People with at least one social scarcity & 83.4 & 85.0 & 84.2 \\
People with at least three social scarcities & 40.3 & 36.6 & 35.1 \\
\hline Indicators of Social Scarcity & & & \\
Schooling backwardness & 30.6 & 26.1 & 27.6 \\
Scarcity of access to health services & 38.2 & 28.6 & 26.2 \\
Scarcity of access to social security & 72.2 & 71.6 & 71.3 \\
Scarcity of quality and spacious housing & 22.4 & 21.1 & 15.4 \\
Scarcity of access to basic housing services & 27.2 & 30.4 & 26.6 \\
Scarcity of access to quality diet & 28.8 & 32.2 & 34.7 \\
\hline Welfare & & & \\
People with lower income than threshold of minimum & 21.6 & 24.2 & 24.4 \\
welfare & 59.1 & 57.9 & 63.3 \\
People with lower income than threshold of welfare & & & \\
\hline
\end{tabular}

SOURCE: Coneval. ${ }^{55}$

54 See Susana María Aguilera, Security, Autonomy and Indigenous Justice: The Alternative Security Model of Cherán, Michoacán 108, 111 (2016) (unpublished MA dissertation, San Diego, University of California). Aguilera affirms that Cherán's legal system has adopted the re-education model for those convicted of crime. From her analysis, we can observe that this system is more focused on the reparation of the offence done to the victim and the community than on punishment for the sake of it. Punishment has a clear purpose: To repair and contribute to the good of the victim and the community as a whole.

55 Coneval, Porcentaje, Número de Personas y Carencias Promedio por Indicador de Pobreza. Michoacán, 2010-2016, 2017. 
To begin with, by the end of the period of $2009-201484.2 \%$ of the local population experienced a kind of social scarcity, 14\% of people lived in extreme poverty, $63.3 \%$ of them did not generate the necessary income to support the threshold of welfare set up by Coneval, among many other relevant descriptive data about the degree of poverty, the social shortfalls and the access to basic services in Michoacán. ${ }^{56}$

In fact, almost all the indicators that measured social shortfalls in Michoacán experienced a setback at the end of the period, for example, the schooling backwardness (rezago educativo) performed worse in 2014 than in 2010, ${ }^{57}$ the share of people in poverty augmented considerably in comparison with the beginning of the period, as well as the percentage of people vulnerable due to a social scarcity. ${ }^{58}$

On the other hand, the portion of people earning an income lower than the cost of the basic food basket grew, but not only in Michoacán but all through the country. ${ }^{59}$ Although it is not the aim of this article to explain the spread of organized crime in Michoacán by means of these descriptive data only, they certainly provide us with the big picture of the social and economic environment that facilitated the recruitment of young people for criminal organisations in Michoacán.

Of course, we must also take into account the decay of family and social values in Michoacán, because it also had an impact on the growth of organized crime in this state. In other words, these descriptive data could demonstrate that, in a context of social scarcities and of shortage of ethical values, criminal organisations tend to recruit many young people for their rank and file.

56 Coneval, Porcentaje, Número de Personas y Carencias Promedio por Indicador de Pobreza. Michoacán, 2010-2016, 2017. In this document, Coneval provides a comprehensive description of poverty and social scarcities in Michoacán. Several indicators were used to measure multiple aspects of poverty and access to basic economic and social goods, such as health and social care, housing, food or a threshold of well-being of people in this state, and they were presented comparatively from 2010 to 2016.

57 Coneval, Porcentaje, Número de Personas y Carencias Promedio por Indicador de Pobreza. Michoacán, 2010-2016, 2017. These data only demonstrate that the schooling level is steadily worsening in this state, which will further hinder its human development, and consequently the conquest of poverty and other social scarcities.

58 Coneval, Porcentaje, Número de Personas y Carencias Promedio por Indicador de Pobreza. Michoacán, 2010-2016, 2017. While in 2010 the share of people in poverty was $54.7 \%$, in 2014 the share rose to $59.2 \%$. Moreover, while in 2010 the share of people experiencing a social scarcity was $83.4 \%$, in 2014 the share rose to $84.2 \%$. These data show that, in spite of the official discourse, there has not been any substantial progress in the conquest of poverty in this state.

59 Coneval, Porcentaje, número de personas y carencias promedio por indicador de pobreza. Michoacán, 2010-2016, 2017. While in 2010 this share was $21.6 \%$, in 2014 the share rose to $24.4 \%$. 


\section{The Gase of Guerrero}

In the period of 2009 to 2014, the social and economic context of Guerrero was even worse than in Michoacán, for example, the percentage of people earning an income lower than the threshold of welfare set up by Coneval was higher in Guerrero than in Michoacán. ${ }^{60}$

Table 2. Social Scarcities in Guerrero (2010-2014)

\begin{tabular}{|c|c|c|c|}
\hline \multicolumn{4}{|c|}{ Percentage } \\
\hline & 2010 & 2012 & 2014 \\
\hline $\begin{array}{l}\text { Poverty } \\
\text { People in poverty } \\
\text { People in moderate poverty } \\
\text { People in extreme poverty } \\
\text { People vulnerable due to social scarcities } \\
\text { People vulnerable due to income } \\
\text { Non poor and non-vulnerable people }\end{array}$ & \begin{tabular}{|l}
67.6 \\
35.7 \\
31.8 \\
23.0 \\
2.0 \\
7.5 \\
\end{tabular} & $\begin{array}{l}69.7 \\
38.0 \\
31.7 \\
21.7 \\
2.3 \\
6.4 \\
\end{array}$ & $\begin{array}{l}65.2 \\
40.8 \\
24.5 \\
26.2 \\
2.6 \\
6.0 \\
\end{array}$ \\
\hline $\begin{array}{l}\text { Social Deprivation } \\
\text { People with at least one social scarcity } \\
\text { People with at least three social scarcities }\end{array}$ & $\begin{array}{l}90.5 \\
60.7 \\
\end{array}$ & $\begin{array}{l}91.4 \\
53.8\end{array}$ & $\begin{array}{l}91.4 \\
51.8\end{array}$ \\
\hline $\begin{array}{l}\text { Indicators of Social Scarcity } \\
\text { Schooling backwardness } \\
\text { Scarcity of access to health services } \\
\text { Scarcity of access to social security } \\
\text { Scarcity of quality and spacious housing } \\
\text { Scarcity of access to basic housing services } \\
\text { Scarcity of access to quality diet }\end{array}$ & \begin{tabular}{|l|}
28.4 \\
38.9 \\
78.5 \\
40.7 \\
56.6 \\
42.7 \\
\end{tabular} & $\begin{array}{l}26.8 \\
25.4 \\
78.5 \\
33.4 \\
59.0 \\
39.4 \\
\end{array}$ & $\begin{array}{l}26.8 \\
19.2 \\
78.1 \\
32.9 \\
58.0 \\
38.5 \\
\end{array}$ \\
\hline $\begin{array}{l}\text { Welfare } \\
\text { People with lower income than threshold of minimum } \\
\text { welfare } \\
\text { People with lower income than threshold of welfare }\end{array}$ & $\begin{array}{l}38.8 \\
69.5\end{array}$ & $\begin{array}{l}45.1 \\
71.9\end{array}$ & $\begin{array}{l}35.6 \\
67.9\end{array}$ \\
\hline
\end{tabular}

Source: Coneval. ${ }^{61}$

Overall, the indicators used by Coneval to measure social and economic scarcities throughout Mexico performed worse in Guerrero than in Michoacán. ${ }^{62}$ Furthermore, following a national tendency all the other indicators

60 Coneval, Índice de la tendencia laboral de la pobreza. Resultados nacionales y por entidad federativa, 2018. Just as an example, while the share of people earning this kind of income in Guerrero was $65.4 \%$, in the third quarter of 2018 , the share in Michoacán was $37.3 \%$ in the same period.

61 Coneval, Porcentaje, número de personas y carencias promedio por indicador de pobreza. Guerrero, 2010-2016, 2017.

$62 I d$. Just as examples, in 2010 the share of people in poverty in Guerrero was $67.6 \%$, while in Michoacán this share was $54.7 \%$, on the other hand, while the share of people in 
of economic and social scarcities suffered a grave reversal at the end of the period of 2010-2015, as can be seen in Table 2 .

According to Coneval, in 2014 the share of people who lived in poverty was $65.2 \%$ and those who lived in extreme poverty formed the $24.5 \%$ of the overall population. ${ }^{63}$ On the other hand, $26.2 \%$ of people in Guerrero were vulnerable due to at least one social scarcity, and $67.9 \%$ of people was earning an income lower than the necessary to buy a basic food basket (canasta básica alimentaria) ${ }^{64}$

However, to make matters worse, the portion of people vulnerable to social scarcities increased from $23.0 \%$ in 2010 to $26.2 \%$ in 2014, and the percentage of vulnerability due to income increased from $2.0 \%$ in 2010 to $2.6 \%$ in 2014, according to these official data. ${ }^{65}$

Finally, the performance of Guerrero regarding the threshold of welfare, was below national average, much worse than in Michoacán, and unfortunately, this threshold is worsening consistently every year. ${ }^{66}$ As it can be observed, there is a strong correlation between extensive social scarcities and the poor human development of Guerrero, with the spread of organized crime across this federative entity.

In addition, Tecoanapa and Ayutla de los Libres were probably the first municipalities where the formation of self-defense groups started in this period. These first vigilantes experienced a paradoxical context though, because while they enjoyed wide popular support, public authorities and some human rights activists condemned their actions from the start. ${ }^{67}$

extreme poverty was $13.5 \%$ in Michoacán, in Guerrero was 31.8\%. There are more examples: While the share of people experiencing scarcity of basic home services in 2010 in Michoacán, was $27.2 \%$, in Guerrero this share was $56.6 \%$. Also, while the share of people experiencing shortage of food in Guerrero in 2010 was $42.7 \%$, this share was 28.8\% in Michoacán.

63 Coneval, Porcentaje, Número de Personas y Carencias Promedio por Indicador de Pobreza. Guerrero, 2010-2016, 2017. The differences between 2010 and 2014 are small. Certainly the share of people living in extreme poverty improved from $31.8 \%$ to $24.5 \%$ in this period, but the share of people living in moderate poverty increased from $35.7 \%$ to $40.8 \%$, and the share of nonpoor and non-vulnerable people decreased $1.5 \%$, from $7.5 \%$ in 2010 to $6.0 \%$ in 2014 .

64 Coneval, Porcentaje, Número de Personas y Carencias Promedio por Indicador de Pobreza. Guerrero, 2010-2016, 2017. These data mean that 2 out of 3 persons cannot buy themselves a basic food supply. This context forces families to multiply their efforts to earn enough income as to sustain a dignifying standard of living, through sending wives and children to work.

65 Coneval, Porcentaje, Número de Personas y Carencias Promedio por Indicador de Pobreza. Guerrero, 2010-2016, 2017. The access to health care remained astonishingly low $(78.5 \%$ in 2010 to $78.1 \%$ in 2014), while the access to basic house services worsened $(56 \%$ in 2010 to $58 \%$ in 2014) in this period.

66 Coneval, Índice de la tendencia laboral de la pobreza. Resultados nacionales y por entidad federativa, 2018. While in Michoacán this share was of $37.3 \%$ in the third quarter of 2018, in Guerrero this share was of $65.4 \%$ in the same period.

67 See Nurit Martínez Carballo, No hay justificación para autodefensa: CNDH, EL Universal, January 28, 2013. 
Another distinctive peculiarity of self-defense forces in Guerrero was that they possessed a visibly stronger social capital than their counterparts in Michoacán. Indeed the UPOEG (Unión de Pueblos Organizados del Estado de Guerrero) coordinated tightly their actions across the state territory, and this civil organisation proved to be quite capable in neutralizing organized crime. ${ }^{68}$ These policías comunitarias detained several people suspected of criminal actions and submitted them to the authorities of the state of Guerrero. ${ }^{69}$

These groups constantly practiced rounds and checkpoints, although they did not have to fight a very powerful and widespread organisation, like the Knights Templar, in Michoacán, but different less powerful criminal gangs distributed across the state. However, local people suffered deeply from extortion practices and the inefficacy of the police and the judicial system against these bands. ${ }^{70}$

In contrast with Michoacán, in Guerrero vigilante groups created, installed and implemented Tribunales Populares to prosecute and judge local criminals, and these events demonstrated how low trust in legal and political institutions fell, within the respective municipalities.

It is obvious that these popular tribunals could not guarantee neither the due process of law nor the constitutional procedural rights of suspected criminal, in order to warrant a fair trial. However, due to the complete failure of the Mexican judicial system in both prosecuting and judging suspected criminals, local people preferred to create, install and put into effect their own popular tribunals. ${ }^{71}$

68 See Juan Cervantes Gómez, Autodefensa guerrerense sigue viva: UPOEG, EL UnIVERsal, February 20, 2013. Bruno Plácido Valerio, the leader of the UPOEG affirmed that their intention was that these self-defense groups would eventually become Policias Comunitarias. The UPOEG, however, held a bitter rivalry with the CRAC-PG (Coordinadora Regional de Autoridades Comunitarias-Policia), another civil association that also coordinated the struggle of other vigilante groups in the region. Despite this rivalry, Guerrero possessed more social capital than Michoacán in the organisation of their self-defense.

69 See Marcos Muédano \& Adriana Covarrubias, Fuerza civil de Ayutla presenta a detenidos, EL UnIVERsal, February 1, 2013. In January 2013, the UPOEG initiated a popular trial against 54 people captured by the "Policías Comunitarias" of Ayutla and Teconoapa, which was held at the main terrace of the town of El Mesón, within the municipality of Teconoapa. The community authorities even created a file folder for each of the suspected criminals to be judged by the people. Understandably, this event triggered the negative reaction of the $C N D H$ and national authorities against this trial: The Mexican state had been overridden. Eventually, the suspected criminals were submitted to constitutional authorities to be tried and judged properly.

70 See Javier Trujillo, Se disputan Guerrero 18 grupos criminales, Milenio, February 20, 2018. According to the then Secretary of Public Security of Guerrero, Pedro Almazán, out of the eighteen criminal organisations that operated in Guerrero, six worked across the nation and twelve only within the state, these last ones being just local gangs.

71 See Marcos Muédano, Inicia juicio de fuerzas civiles, El UnIVERsal, January 31, 2013. In 31 January 2013, local people in Ayutla de los Libres tried and judged suspected criminals who were accused of kidnapping, extortion, rape and robbery. 
Map 2. Municipalities of Guerrero with Self-Defense

Groups (2015)

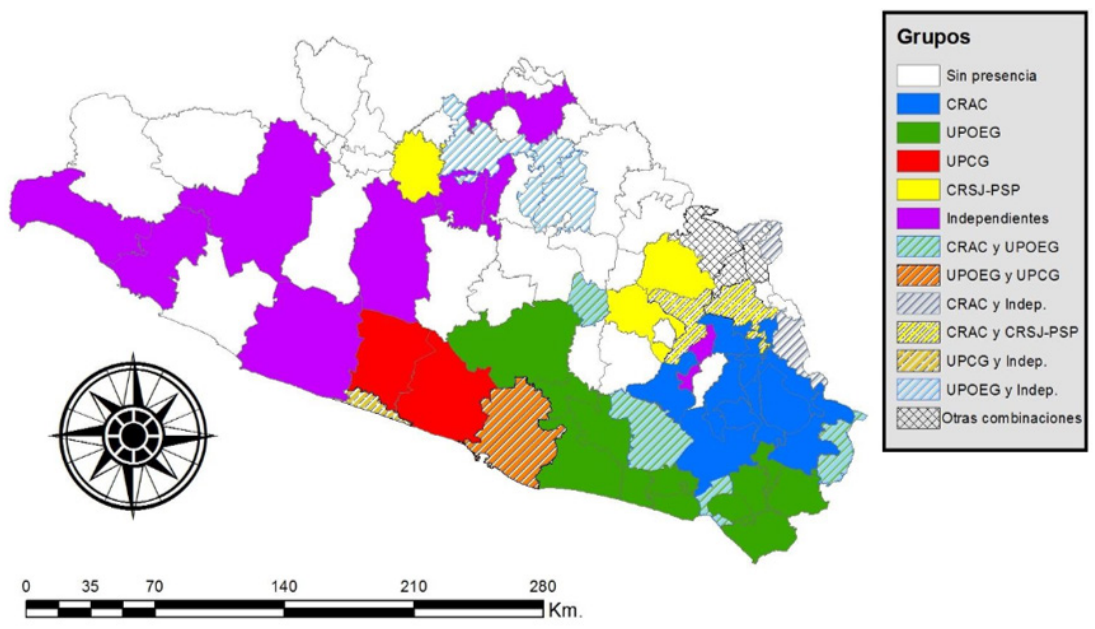

SOURCE: Víctor Manuel Sánchez Valdez. ${ }^{72}$

The implementation of these tribunals provoked the alarm of the CNDH, due to its justified fear that they could arbitrarily suppress fundamental human rights of suspected criminals, by not respecting the due process of law and the constitutional procedural rights of suspected criminals. ${ }^{73}$

Although slightly less severely than in Michoacán, people in Guerrero endured likewise an abnormal situation, as well as the constraint to carry out their ordinary lives, and a serious deterioration of their standards of living, precisely because of the harassment from organized crime. To sum up, attributes of a serious detriment to public peace could be observed.

With respect to a pressing threat, people in Guerrero did suffer threat strictly speaking, because organized crime practiced extortion, kidnapping, rape, murder, theft and other violent crimes, with increasing ruthlessness and cruelty.

Furthermore, their fundamental rights were at high risk due to this devastating activity of organized crime and, ultimately, with regard to the danger

72 In Building Resilient Communities in Mexico: Civic Responses to Crime and ViOLENCE 14 (Woodrow Wilson International Center for Scholars and The University of San Diego, 2015).

73 See Javier Cruz Angulo, Dictaduras Comunitarias, El Universal, January 31, 2013. In this article, the author recalled that there had been grievous precedents of abuse of human rights, by popular tribunals erected by self-defense groups in Guerrero. Angulo claimed that these groups had overridden the Mexican Constitution, and that they had acted above it, behaving arbitrarily (with demagoguery) at imposing sentences to suspected criminals, without sufficient evidences. 
of this risk, perhaps the best indicator of this circumstance was the exasperation of the people and their decision to try and judge, by themselves, suspected criminals through popular trials.

Finally, respecting a dangerous conflict, we can claim that the calamitous activity of organized crime and the absence of the Mexican state triggered a bitter violent conflict between criminals and the vigilantes, to the point of overriding the constitutional judicial system to settle their differences.

Certainly, organized crime in Guerrero was not so solidified across the state as in Michoacán, so although the distress was real, people in Guerrero could neutralize better their threat than their counterparts in Michoacán.

Finally, the most severe symptom of emergency in Guerrero was the de facto replacement of the constitutional judicial system by a customary one in several municipalities across the state. This replacement could have represented a syndrome more of exasperation than of desperation of the people. It could also have been a clear sign of the strength of social capital and of the power of civic organisations against criminal ones across the state. Thus, Guerrero might be considered a good example of how a strong social capital contributes decisively in the struggle against organized crime.

\section{Other CAases}

From Sonora to Yucatán ${ }^{74}$ civil society in Mexico has organized vigilante groups to protect their lives, freedoms, properties and their fundamental rights from crime. In all these cases, people have complaint of the absence of the state facing crime. ${ }^{75}$

By the end of 2013, there were versions that self-defense groups were present in eleven states of Mexico. ${ }^{76}$ However, this number has increased in recent years, and nowadays there are claims that these groups are also present in states that were considered relatively safe, such as Yucatán, Sonora, Quintana Roo or Mexico City. ${ }^{77}$

74 See Eduardo José Cabrera Ruiz, Nuevos Grupos de Autodefensa ... ahora en Tucatán, Excelsior, March 20, 2013. For example, in Yucatán, at the municipality of Kanasín, self-defense groups armed themselves with sticks and machetes to stop robberies and rapes in their neighbourhoods.

75 See Redacción, Ahora en Sonora irrumpe grupo de autodefensa; lo encabeza un ejidatario llamado Francisco Villa, Proceso, February 5, 2014. For example, both in Sonora and Sinaloa, some ejidatarios organized self-defense groups to protect their properties and homes from being burned and robbed, at the same time they accused state authorities of passivity in front of crime.

76 See Grillonautas2, Grupos de Autodefensa presentes en 11 estados del país, Youtube, December 21, 2013, https://wwre:youtube.com/watch? $v=$ EVhtdeGTwow. These states were: Michoacán, Guerrero, Oaxaca, Estado de México, Chiapas, Morelos, Veracruz, Puebla, Hidalgo, Tlaxcala and Chihuahua.

77 See Redacción, Empresarios de Quintana Roo crean grupo de autodefensas contra corrupción, ANIMaL Político, June 28, 2017. In Quintana Roo, businessmen unleashed in 2017 a new self-de- 
An interesting case, in the period of 2009 to 2014, was Chihuahua. In this state, people suffered desperation likewise, due to the violence and ruthlessness of organized crime, so they to self-defense, despite of the criticism of Human Rights activists and authorities alike. ${ }^{78}$ On the other hand, another state that has suffered immensely the violence of organized crime is Tamaulipas, to such an extent, that, during many years local people could not exercise civil liberties to associate and meet to plan their self-defense. ${ }^{79}$

Many municipalities in this state lived a de facto subjection to organized crime, which controlled all their ordinary activities and properties. ${ }^{80}$ People literally lived terrorized and with utmost fear, in such a way, that they could not speak publicly about the wrongdoings of organized crime and the sufferings its members were causing them, inasmuch as they were immediately eliminated should they intend to do so. ${ }^{81}$

Nevertheless, by early 2014, the first reports about vigilante groups in this state were published. These groups, like their counterparts in Michoacán, were facing very powerful criminal organisations that had destroyed trust and social capital in Tamaulipas, thus the capacity of people to capably organise their self-defense. That is why the task of overcoming drug cartels was enormously difficult for these new vigilante groups.

fense group against the very same governor of the state, Carlos Joaquín González, who they accused of leading a new drug cartel, which was extorting many businesses in that state. On the other hand, in 2013 there were rumours that the Counties of Tlalpan, Iztapalapa and Xochimilco, in Mexico City, had self-defense forces as well, although the government of Mexico City always denied this fact. See Ilich Valdez, No habrá autodefensas en la ciudad: Mancera, Milenio, November 25, 2013.

78 See Redacción, Advierten riesgos por milicias comunitarias, El UNIVERSAL, July 11, 2009. Due to high rates of violent crimes, the government of Chihuahua decided to arm and train civilians, at the community of "Le Baron", to perform police tasks, as a strategy to neutralize organized crime. The state authorities of Chihuahua openly proposed collaboration and coordination with civil society to conquer crime.

79 For example, Ciudad Mier, Tamaulipas, by 2010, became a ghost town, since almost all its population had to emigrate to neighbour towns or even to the United States of America, due to the ruthless death threats of organized crime. See Gustavo Castillo García, Amenazas de muerte de Zetas hacen de Mier, Tamaulipas, pueblo fantasma, La JornaDA, November 11, 2010; and see Axellmx1, Ejército ingresa a pueblos fantasma de Tamaulipas, YouTube, December 8, 2010, https:// wwre:youtube.com/watch? $?^{2}=$ FNpIFSR1bb4.

80 The main criminal organisation operating in this state was Los Zetas, perhaps the bloodiest and most ruthless that has ever existed in Mexico. There were other two which intended to defeat Los Zetas in this state, the Sinaloa Cartel and the Gulf Cartel. See Said Rahal, Narcos dejan pueblos fantasmas en Tamaulipas, Youtube, March 2, 2010, https://wrere.youtube.com/ watch? $v=g k X O u 4 K v X p 4$.

81 See Axellmx1, Ejército ingresa a pueblos fantasma de Tamaulipas, 2010. 


\section{Analysis of the Legal Feasibility of a Declaration of State of Emergency in Mexico}

The doctrine explained by Robert Alexy on balance and deliberation of the right to protection (of basic goods) and the right to defense (of liberties), can provide us with a proper criterion to discern the necessity, proportionality and adequacy, of a suspension of constitutional guarantees and of the enactment of emergency laws, so that the constitutional order may be restored completely in specific regions of Mexico.

In consonance with Robert Alexy, ${ }^{82}$ the right to protection (of basic goods) implies the duty of the state to perform a positive action aimed at safeguarding fundamental rights. However, sometimes the necessary action that could protect these basic rights interferes with or harms a particular right to defense (of a liberty). Alexy believes that the fair solution in this hypothetical collision of rights consists in balancing, in accordance with the principle of proportionality, both kinds of rights. ${ }^{83}$

Furthermore, the principle of proportionality is composed of three subprinciples: a) adequacy, b) necessity and c) proportionality in strict sense. Adequacy implies that a constitutional guarantee should not be violated unless its transgression pursues the enhancement of another constitutional right. ${ }^{84}$ In addition, necessity suggests that if the state must choose between two methods of protecting fundamental rights, the one that interferes the least with the right to defense (of liberties) should be chosen. ${ }^{85}$

Lastly, proportionality in strict sense proclaims the principal law of balance and deliberation: "As much as a principle may be harmed, so much important is to guarantee the other one". ${ }^{86}$ Robert Alexy expresses this principle through a mathematical formula:

$$
W_{i, j}=I_{i} / I_{j}
$$

Where $\left(\mathrm{W}_{\mathrm{i}, \mathrm{j}}\right)$ means the weight of principle $\left(\mathrm{P}_{1)}\right.$ in the particular study case, $\left(\mathbf{I}_{\mathrm{i}}\right)$ stands for the damage of $\left(\mathrm{P}_{1}\right)$ by a particular measure $(\mathbf{M})$, and $\left(\mathbf{I}_{\mathrm{j}}\right)$ implies the negative effects of the omission of $(\mathrm{M})$ (and of the omission of the damage to $\left.\left(\mathbf{P}_{1}\right)\right)$, to the principle $\left(\mathbf{P}_{2}\right)$.

In this formula, $\mathrm{P}_{1}$ symbolizes the constitutional right to protection (of basic goods), $\mathrm{P}_{2}$ speaks of the constitutional right to defense (of liberties). ${ }^{87}$

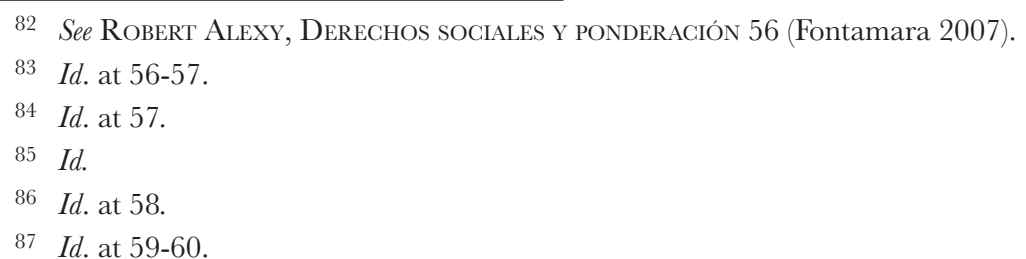


Thus, from the principle of proportionality and its sub-principles, we can draw two interesting conclusions:

A) If the harm to a right to defense (of liberties), caused by implementing a particular measure $(\mathbf{M})$, is greater than the harm to a right to protection (of basic goods), by not adopting this measure (-M), then this measure should not be implemented, for the sake of enhancing constitutional liberties.

B) But, if the harm to a right to protection (of basic goods), caused by not implementing a particular measure $(-\mathbf{M})$, is greater than the harm to a right to defense (of liberties), by adopting this measure (M), then this measure should be implemented, for the sake of preserving fundamental rights. ${ }^{88}$

The argument of this article is that the second conclusion was the case of Michoacán Guerrero and other states of Mexico, in the period of 2009 to 2014 , because the suspension of constitutional guarantees and the enactment of emergency laws, would have benefited enormously the right to protection (of lives, properties, physical integrity, fundamental freedoms, etc.) of common people, and would not have harmed intensely their right to defense (of specific civil liberties).

In few words, the rights that needed to be protected by the state (lives, properties, freedoms, physical integrity, etc.) were far more relevant than the rights that needed to be defended from the intrusion of the state (e.g. confidentiality of bank accounts, restriction of movement in certain hours, prohibition of public gatherings).

There must be a comparative value judgment between the enforcement of the rule of law $\left(\mathrm{P}_{1}\right)$ and specific constitutional guarantees of explicit people $\left(\mathrm{P}_{2}\right)$. The Mexican state has the responsibility of securing its viability, even at the cost of not respecting, momentarily, constitutional rights of particular people (e.g. the right to an orthodox criminal procedure or some rights to confidentiality in financial matters).

This means that whenever $\left(\mathrm{P}_{1}\right)$ (the rule of law) is in danger, $\left(\mathrm{P}_{2}\right)$ (orthodox criminal procedure) or $\left(\mathrm{P}_{3}\right)$ (specific civil liberties or particular rights of confidentiality) should be left aside, because $\left(\mathrm{P}_{1}\right)$ protects a far more relevant good for society than $\left(\mathbf{P}_{2}\right)$ or $\left(\mathbf{P}_{3}\right)$. In fact, crimes against the state $\left(\mathbf{P}_{1}\right)$ entail the destruction of all that could make people happy and enjoy their fundamental rights: life, freedoms, property, integrity, human development $\left(\mathrm{P}_{2}, \mathrm{P}_{3}\right.$, etc., etc., that is why the right to a functioning, healthy, capable and strong state $\left(\mathrm{P}_{1}\right)$ prevails over other constitutional rights $\left(\mathrm{P}_{2}, \mathrm{P}_{3}\right.$, etc. $)$, no matter how basic they appear to be.

88 Id. at 63-65. 
Nevertheless, if the state is not enduring a pressing threat to its viability or living through a grave distress, then $\mathrm{P}_{2}, \mathrm{P}_{3}$, etc. (constitutional guarantees) are worth more than any public policy that pretends to strengthen the rule of law $\left(\mathrm{P}_{1}\right)$, but damages at the same time these constitutional rights. This means that, in ordinary and peaceful circumstances, procedural rights of suspected criminals should always be respected. In this case, there would be no excuse to override these rights.

The first source of power of the state is its viability, and once it works, it makes the constitutional rule of law function as well. This implies that, in case of a hazardous threat, some constitutional rights should be overridden to guarantee the existence of the state and the rule of law.

To judge the case of Mexico fairly, based on the doctrine of balance and deliberation of Robert Alexy, it is important to answer the following questions: Would the suspension of constitutional guarantees in Michoacán, Guerrero and other regions, in the period of 2009-2014, have been a competent measure to address efficiently their distress?

Our argument is yes, it was a fitted action, because it would have been at the service of restoring the constitutional order in these regions, thus at the service of protecting fundamental rights of people living there.

The second question is would it have been necessary to suspend constitutional guarantees and enact emergency laws in Michoacán, Guerrero and other regions, in the period of 2009-2014, to capably oppose organized crime? Our answer is yes, it would have been necessary, but the options to subdue competently criminal organisations were wide, and the Mexican government was forced to choose one that would have been efficient and would have damaged as little as possible procedural, civil and political rights of people.

The final question is would the suspension of constitutional guarantees have been proportionated with the distress that Michoacán, Guerrero and other states suffered in the period of 2009 to 2014? Our answer is yes, it would have been proportionated. However, ideally it should have lasted a short period of time, because it would have been quite powerful in re-establishing the rule of law and guaranteeing the protection of human rights.

Conversely, the suspension of constitutional guarantees and the enactment of emergency laws could have helped competently in dismantling rapidly criminal organisations in these regions, and in enhancing the responsiveness of the Mexican state against drug-cartels.

Furthermore, these measures could have improved the intelligence of the Mexican state (strategic and tactical) in order to break down the financial support and supply of arms for drug cartels, through allowing direct access to confidential information from economic transactions related to these criminal activities. ${ }^{89}$

89 See John Bailey, Grimen e impunidad. Las trampas de la seguridad en México 214 , 219 (Random House Mondadori 2014). 
On the other hand, emergency laws could have powerfully worked to improve institutional coordination by avoiding duplicity of functions and unifying protocols to detain suspected criminals. Moreover, the formal declaration of emergency in these regions could have provided space-time for the quality improvement of institutions and physical infrastructure to capably enforce the rule of law. ${ }^{90}$

In addition, emergency laws could have contributed to improve mechanisms of control of authorities and society (judicial, assets, anti-corruption and social), in specific regions of Mexico or throughout the country. ${ }^{91}$ Finally, these laws could have also contributed to achieve a capable law enforcement system, as well as competent prosecutorial and judicial systems, to vigorously strike organized crime, and which could have continued, in substance, after the emergency would have formally ended. ${ }^{92}$

\section{Proposing Typologies of Emergency and Vigilantes in Mexico}

In terms of the severity of the emergency, it can be sustained that Guerrero bore a less intense distress than Michoacán. People in Guerrero could manage to make their suffering more tolerable, by implementing popular tribunals; and this replacement of the constitutional judicial system, by a customary (indigenous) one, plus the scattering of criminal organisations across the state, made people possess a better context to face up to organized crime.

Concerning the strength of self-defense groups, Guerrero's vigilantes could be rated as first class forces, since they had been strongly solidified through widespread civic organisations, whereas the vigilantes in Michoacán can be considered as second class forces, because they had not been unified through widespread social capital, but were only well coordinated around a strong personal leader (José Manuel Mireles Valverde) in order to stand up to the Knights Templar.

On top of that, it could be observed that the forces in Michoacán were more vulnerable to the infiltration of organized crime than in Guerrero. On the other hand, the forces in Guerrero were more cohesive and better coordinated.

The third-class forces, in terms of their strength, were those that had worked dispersedly, without coordination, thus being left with much more difficulties to conquer their common enemy. This could well be the case of self-defense groups in other federative entities, like Tamaulipas, Chihuahua, Sonora, Yucatán and Quintana Roo.

\footnotetext{
90 See Id. at 47, 48.

91 See Edgardo Buscaglia, Vacíos de poder en México. Cómo combatir la delincuenCIA ORGANIZADA 28, 29 (Random House Mondadori 2013).

92 Id. at 179, 200.
} 
Nonetheless, after the analysis of primary data, it is possible to argue that vigilantes in Guerrero put into effect more like a rebellious movement against organized crime, whereas vigilantes in Michoacán implemented more a kind of ruthless war, because their enemy was more difficult to defeat.

However, in both cases we could notice an acknowledgment that the rule of law was not capable of neutralizing solidly organized crime; that is why it was set aside in some municipalities, so that the indigenous customary law could instead rapidly restore peace and order.

\section{The Gurrent Debate on the State of Emergency in Michoacán, Guerrero and Other Troubled Regions in Mexico}

Some scholars have argued that there are different options to a formal declaration of state of emergency, which do not entail the restriction of nonperemptory human rights and could be equally effective in improving public, interior and national securities in Mexico, particularly in Michoacán and Guerrero. ${ }^{93}$ For example, the implementation of sensible measures of intelligence, strategy and technology in order to capture, subjugate and institute proceedings against members of organized crime. ${ }^{94}$

Nonetheless, Mexican authorities have attempted to implement policies other than a formal declaration of state of emergency, such as the sanction of the Law on Interior Security and the Law on National Security, whose enforcement, incidentally, has implied the acknowledgement of a de facto state of exception in some regions of Mexico, and has authorized military actions that can only be performed in the course of emergency periods. ${ }^{95}$

In contrast, a formal derogation of non-peremptory human rights norms, which is the logical output of a formal declaration of state of emergency, if properly implemented, would not standardize an abnormal situation. On the other hand, the enforcement of these laws could turn a factual state of emergency into an endless state of affairs, by way of authorizing the inter-

93 For example, Carlos Galindo López, et. al., Seguridad interior: elementos para el debate, 39, Tem. Estr. 33, 34 (2017), mention different policies that should be discussed, at the national level, to achieve this goal: a) judicial reform, b) police reform and professionalization, c) the autonomy of prosecutors, among others.

94 See John Bailey, Grimen e impunidad. Las trampas de la seguridad en México 192, 231 (Random House Mondadori 2014). This scholar provides thoughtful and comprehensive policy advices to the Mexican government in order to enhance citizen security and overcome organized crime throughout Mexico.

95 See, for example, Marcos Pablo Moloeznik, El proceso de militarización de la seguridad pública en México (2006-2010), 24 (48) FRON. N. 138, 139 (2012). This scholar argues that if the official judicial interpretation states that Mexico is living peaceful times, then Art. 129 of the Mexican Constitution should be fully enforced: The army should not go out from their proper stations. 
vention of military forces in the prosecution of organized crime in ordinary circumstances. ${ }^{96}$

Additionally, emergency powers can nurture the rapid, decisive and efficient response of Mexican authorities to reestablish public, interior and national securities in Mexico, and hastily restore the constitutional order across this country, once criminal organizations are effectively curbed through these powers. Furthermore, a formal declaration of a state of emergency would force the Mexican state to design and publish, as soon as possible, a detailed plan of action to reinstate effectively the constitutional order and enforce efficiently the rule of law across all those regions struck by organized crime. ${ }^{97}$

Additionally, this kind of declaration would imply the formal acknowledgement of a crisis, thus the need for the Mexican President to exercise extraordinary faculties in order to face such a situation and reestablish constitutional normality. On the other hand, the Law on Interior Security and the Law on National Security point the way to the standardization of the intervention of military forces in the prosecution of organized crime, which could increase the ordinary distress of Mexican society, because of the lack of a specific plan and dateline to bring back constitutional normality. ${ }^{98}$

Nevertheless, it is a reality that the Mexican state faces such serious security challenges that, a transitory derogation of non-peremptory human rights norms, through a formal declaration of state of emergency, may still seem as an insufficient mechanism to competently meet those challenges.

This circumstance could explain why the approval of these laws was so well regarded and welcomed by presidents Fox, Calderón and Peña Nieto, and their followers, in their respective administrations (sexenios), since these laws provided them with practical tools to manage the armed conflict with organized crime, without committing themselves to develop a thorough and detailed plan to restore the constitutional order within a specific dateline, as a formal declaration of state of emergency would have forced them to accomplish. ${ }^{99}$

Because of this situation, the authorization of these laws could have also meant that both the public emergency and the humanitarian crisis brought

96 See Antonio Barreto Rozo et. al, Los costos constitucionales de la guerra contra las drogas: dos estudios de caso de transformaciones de las comunidades políticas 43 ISON. 151, 193 (2015). These scholars claim that once the Law on National Security started to be effective (2005), there was no longer clarity about the specific functions that the army can perform in the fight against organized crime in Mexico.

97 John Ferejohn, et al, The Law of Exception: A Typology of Emergency Powers, 2 (2) InT. Const. L. 217, (2004). Moreover, these authors argue that "once the emergency subsides, there will be a return to ordinary legal and political processes".

98 Laura Medellín Mendoza, El resguardo de la soberanía del Estado constitucional en la lucha contra el crimen organizado en México, 12 (31) TraY. 126, 129 (2010).

99 See Laura Medellín Mendoza, El resguardo de la soberanía del Estado constitucional en la lucha contra el crimen organizado en México, 12 (31) TraY. 126, 129 (2010). 
about in some regions of Mexico by the destructive activities of organized crime, were much worse than initially thought, and they could have symbolized the recognition of the Mexican state of its incapacity to solve these crises through transitory emergency powers.

Moreover, the ugly truth is that, although unacknowledged, some regions of Mexico, like Michoacán and Guerrero, live in a quasi-state of war, since organized crime constantly carries out extremely ruthless strategies to permanently undermine the Mexican state's army, police forces, rule of law and ordinary institutional framework. ${ }^{100}$

Because of this state of affairs, the Mexican legal doctrine needs to update its interpretation of a public emergency, based on the most recent and relevant scholarly contributions, so that rising social hostilities executed by non-state agents and aimed at subjugating state authorities can be faced up properly and successfully, by the Mexican state, without the need to enact controversial laws.

On the other hand, some scholars have asserted that the Mexican state has not observed its constitutional principles at sanctioning the Law on Interior Security and the Law on National Security since, according to them, these laws were not properly based on the Mexican Constitution, and they openly contradicted its Art. 129.101

In contrast, a formal declaration of state of emergency and derogation of non-peremptory human rights norms would avoid this kind of criticism by being duly motivated and justified in Article 29 of this Constitution, since its aim would be to restore the constitutional order harmed by the calamitous activities of organized crime.

Furthermore, a formal state of emergency could stop the process of alteration (or reinterpretation) of the Mexican Constitution, which both the Law on Interior Security and the Law of National Security have prompted in order to justify the ordinary intervention of military forces in the prosecution of criminal organizations. ${ }^{102}$

Moreover, the Law on Interior Security and the Law on National Security might become counterproductive in the long term, because they address the armed conflict against organized crime as if it were an ordinary issue, in which constitutional principles could be entirely complied with. In contrast,

100 Precisely in the third week of October 2019, there were four serious attacks to police and military forces across Mexico: in Michoacán (14/10/2019), Guerrero (15/10/2019), Tamaulipas (16/10/2019), and Sinaloa (17/10/2019).

101 See, for example, Carlos Galindo López et al., Seguridad Interior: Elementos para el debate, 39, Tem. Estr. 12, 24 (2017).

102 See Laura Medellín Mendoza, El resguardo de la soberanía del Estado constitucional en la lucha contra el crimen organizado en México, 12 (31) TrAY., 108 (2010). This scholar has criticized that, in Mexico, the constitutional order has been interpreted in order to justify government decisions, based on certain official goals, but without considering the original intention of the constitution-maker. 
a formal state of emergency would openly acknowledge that these principles could not be fully respected in this commitment, since the institutional disturbance caused by criminal organizations in some regions of Mexico should be deemed as critical or exceptional in nature. ${ }^{103}$

Moreover, through the formal declaration of a state of emergency, in the course of dismantling criminal organizations the state could avoid the weariness of being constantly accused of non-peremptory human rights violations. However, in the long term, this formal declaration could better guarantee the definitive restoration of the rule of law in Mexico, hence the conclusive enforcement of all human rights across all those regions struck by organized crime. ${ }^{104}$

Finally, a formal declaration of state of emergency in Michoacán, Guerrero and other regions of Mexico might stop and repair some of the "constitutional costs" that military forces have produced to the Mexican state while guaranteeing public, interior and national securities across these regions. ${ }^{105}$

\section{Final Considerations}

The fact that the constitutional judicial system could not preserve human rights of victims of organized crime, the reality that fundamental rights were substantially overridden by this crime, and the truth that horrendous abominations were overwhelming in Michoacán, Guerrero and other states, constituted a solid ground for the acknowledgement of a constitutional crisis in these regions.

Furthermore, these circumstances prompted either a serious threat or a dangerous conflict or a grave detriment to public peace (each one being a sufficient condition for the valid suspension of constitutional guarantees) in the regions of study of the present research.

103 See Laura Medellín Mendoza, El resguardo de la soberanía del Estado constitucional en la lucha contra el crimen organizado en México, 12 (31) TRAY. 126, 129 (2010). Medellín regrets that, in practice, these laws pave the way for a de facto state of emergency in Mexico, which is actually a far worse situation than a de jure or formal declaration of state of emergency that the Mexican President could have made.

104 See Evan J. Criddle \& Evan Fox-Decent, Human Rights, Emergencies and The Rule of Law, 34 Hum. R. QUART. 41 (2012). In order to stress this end goal of a formal declaration of state of emergency, these scholars argue that "Non-peremptory human rights norms are subject to derogation in contexts where the strict observance of these norms would conflict with the state's overarching fiduciary obligation to guarantee subjects' secure and equal freedom."

105 See Antonio Barreto Rozo et al., Los costos constitucionales de la guerra contra las drogas: dos estudios de caso de transformaciones de las comunidades políticas, 43 Ison., 151, 193, (2015). These authors have classified the "constitutional costs" that Mexico has endured in its "war on drugs" since 2006: a) The restriction on fundamental rights, b) The centralization of a federalist system, and c) The confusion about the faculties of different public institutions in the fight against organized crime. 
If we consider that criminal organisations in Mexico use ruthless war tactics to subject people, that they are merciless, that they have no respect for innocent people, it is opportune to ask the following question: Is it judicious in this context to be concerned with protecting scrupulously all constitutional rights of members of criminal organisations?

Unfortunately, the normative response of the $\mathrm{CNDH}$ and other Human Rights Organisations to this question, instead of solving the grave crises in these regions, impeded the timely design of constructive policies that could have helped the Mexican state to competently defend the basic rights of common people in front of organized crime.

All the same, this normative reply has rendered ineffective the Mexican state to neutralize conclusively organized crime. Moreover, this outlook has led many regions of this country to live in a permanent state of subjection to drug cartels, by which human rights of common people are trampled upon ruthlessly. Thus, the lack of acknowledgement of the crisis suffered in these regions is unfair for the millions of people who live there.

A formal declaration of emergency would be an acknowledgement of the true reality that this people endure. Conversely, the refusal to acknowledge this fact would expand severe consequences against these people.

On the other hand, the Mexican Law has not advanced adequate criteria to esteem, in a context of absence of the state, the fairness of self-defense against ruthless crime. Consequently, this lack of fair criteria emboldens more and more criminal organisations, because they feel over protected, whereas ordinary people feel increasingly desperate on the grounds that they perceive that the Mexican state has leaned more to the side of criminals than to their side.

Furthermore, the distress lived through in Guerrero and Michoacán resulted in the revival of indigenous customary law, since people needed to recover their ancestral traditions and customs to conquer organized crime and achieve their own development.

Based on the two main cases studied in this research, we infered that, through a robust human development and the efficient encouragement of social capital, people in Mexico could be able to efficaciously fight criminal organisations throughout the country.

Finally, the suspension of constitutional guarantees and the enactment of emergency laws are part of the portfolio of powerful instruments to reconstruct the peace, order, security and respect of human rights in the Mexican state. Nonetheless, to produce the expected result, they need to be accompanied by upright policies that shall redesign, for ordinary times, the law enforcement, the prosecutorial and the judicial systems, so that they guarantee the appropriate punishment and reparation of criminal actions, as well as the control mechanisms (judicial, assets, anti-corruption and social) ${ }^{106}$ of the authorities and society to prevent the growth of organized crime in Mexico.

106 See Edgardo Buscaglia, Vacíos de poder en México. Cómo combatir la delincuenCIA ORGanizada 28, 29 (Random House Mondadori 2013). 


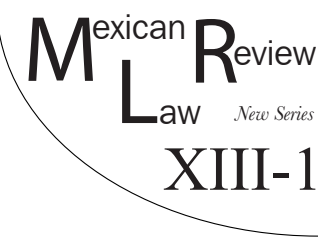

\title{
REVIEW OF THE INTERNATIONAL PATENT SYSTEM: FROM THE VENICE STATUTE TO FREE TRADE AGREEMENTS
}

\author{
Claudia Angélica Córdova GonzÁlez* \\ Mónica Guadalupe CHÁvez ElorzA**
}

\begin{abstract}
The current international patent system emerged within certain economic, political and social conditions in specific territories and periods. It has its historical roots in the Statute of Venice (1474), the Statute of Monopolies (1624), the United States Patent Law (1790), the French Patent Law (1791) and the Paris Convention (1883). Over time, these laws shaped a new model, which currently prevails. To strengthen the analysis of this article, the Agreement on Trade-Related Aspects of Intellectual Property Rights (1994), as well as free trade twentieth century agreements are integrated into the discussion. It is worth noting that each amendment stressed the economic relevance of the patent and its use to benefit certain economic elites through the creation of monopolies. Consequently, the debate on the purposes and nature of the international patent system has also been constant from its emergence to the present. This article provides basic elements for reflection about the origin, purposes and scope of national patent models implemented in Latin America within the global trend of scientific-technological innovation for development.
\end{abstract}

Keywords: Statute of Venice (1474), Statute of Monopolies (1624), United States Patent Law (1790), French Patent Law (1791), Paris Convention (1883).

RESUMEN: El sistema internacional de patentes vigente apareció a partir de ciertas condiciones económicas, políticas y sociales en territorios y periodos con-

* Candidate for a $\mathrm{PhD}$ in Development Studies from the Autonomous University of Zacatecas, and Master in Political Science from the same university.

** PhD in Public Policy from the School of Government and Public Policy from the Tecnológico de Monterrey, and Master in Applied Economics from the Colegio de la Frontera Norte.

This article is part of the research project A1-S-9013: "Evaluación de impacto de las politicas públicas en la productividad científica, tecnológica e innovadora en México", Convocatoria de Investigación Básica 2017-2018 SEP-CONACYT. 
cretos. Se destacan dentro de sus antecedentes históricos el Estatuto de Venecia (1474), el Estatuto de Monopolios (1624), la Ley de Patentes de Estados Unidos (1790), la Ley de Patentes de Francia (1791) y el Convenio de París (1883). Con el paso del tiempo estos fueron configurando un nuevo modelo que es el que impera actualmente. Para fortalecer el análisis del presente artículo se integra a la discusión el Acuerdo sobre los Aspectos de los Derechos de Propiedad Intelectual relacionados con el Comercio (1994), así como tratados de libre comercio del siglo XX. Cabe resaltar que con cada enmienda fue dominando la importancia económica de la patente y el uso de esta para beneficiar a ciertas élites económicas por medio de la creación de monopolios. Como consecuencia de lo anterior, el debate sobre los propósitos y naturaleza del sistema internacional de patentes ha sido también una constante desde su aparición hasta la actualidad. Este artículo da elementos básicos para la reflexión sobre el origen, los fines y los alcances de los modelos nacionales de patentes instituidos en Latinoamérica en la tendencia global de la innovación científica-tecnológica para el desarrollo.

Palabras clave: Estatuto de Venecia (1474), Estatuto de Monopolios (1624), Ley de Patentes de Estados Unidos (1790), Ley de Patentes de Francia (1791), Convenio de París (1883).

\section{TABle of Contents}

I. INTRODUCTION.

II. Origins of the Patent System ................................................ 68

1. Statute of Venice.................................................................... 68

2. Statute of Monopolies ......................................................... 71

3. French Patent Law .............................................................. 74

4. United States Patent Law..................................................... 77

III. International Patent System. Contrasts Between Laws and First Elements Towards Homogenization ................................ 80

IV. International Patent System. A New Turn................................ 87

1. Establishment of the Paris Convention..................................... 87

2. Formation of the Patent Cooperation Treaty …........................ 90

V. Intellectual Property and International Trade ....................... 92

1. Agreement on Trade-Related Aspects of Intellectual Property Rights (TRIPS) .................................................. 94

2. Free Trade Agreement ..................................................... 96

3. Regional Economic Integration in South America.................... 97

VI. Goncludsion n.................................................................... 99 


\section{INTRODUCTION}

The current international patent system emerged without a predetermined legal structure based on the fundamental principles of law, that is, it arose from certain economic, political and social conditions in specific territories and periods. At the beginning of the fifteenth century, some Italian city-states based their economic growth mainly on trade. Inventions, developed through the importation of foreign knowledge, played a central role in the merchants' guild, which promoted technological competitiveness. ${ }^{1}$ They saw the letters patent as a possibility of acquiring a monopoly for a certain time and sought to establish a regulatory system of inventions, which had changed over time and which currently has adapted to meet new global trends.

In some national and international reforms, they set out to establish precise parameters for the patentability of an invention, also to give greater certainty to the moral and economic rights of the inventors and/or owners of the patent, to broaden the territorial extension of the right to property, possession and/or exploitation of a patent, as well as the establishment of rules and penalties for the resolution of disputes, some of them derived from ius prohibendi. ${ }^{2}$ It should also be noted that with each amendment, the economic relevance of the patent and the proclivity to favor certain economic elites through the creation of monopolies were highlighted. As a result, the debate on the purposes and nature of the international patent system has also been a constant from its emergence to the present.

This article deals with three relevant topics to deepen the patent analysis. In the first place, a study of the relevant ordinances and conventions in the matter has been made starting with the 1474 Statute of Venice up to the current dominant system, in particular the 1883 Paris Convention, the 1994 Agreement on the Aspects of the Rights of Trade-related Intellectual Property (TRIPS), and the 1978 Patent Cooperation Treaty (PCT). Likewise, the institution created to manage TRIPS will be discussed; this will identify the particularities and contexts under which those ordinances and conventions were established.

Secondly, an analysis of the Free Trade Agreements (FTA) and TRIPS, which emerged in the 1990s and which influenced the adjustment of the local legislation in the signatory countries in accordance with the International Patent System, will be carried out taking as examples the cases of the Mexican and the Andean Communities.

Finally, some conclusions are presented regarding the elements analyzed on the origin and purposes of the International Patent System. Therefore, we

1 C. Allen Nard et al., Constitutionalizing Patents: From Venice to Philadelphia, Review of Law \& Economics, Vol. 2, No. 2 (2006).

2 This means the power of the owner of an industrial property right to prevent its use by third parties. See http://dej.rae.es/lema/ius-prohibendi. 
expect to identify the possible future scenarios for the system and its effects at a global level and especially in Latin America.

\section{Origins of the Patent System}

The first antecedent of the International System of Representatives is the Statute of Venice that emerged in the fifteenth century, in the city of Venice, in the context of a commercial boom and high regional competitiveness that sought to boost innovation.

Subsequently, in 1623, the Statute of Monopolies was established in England. It derived from the disputes between the Crown and the Parliament to eliminate its discretion in granting monopolies to certain people who affected the population negatively by rising merchandise prices and, at the same time obstructed the progress of certain industries. The Statute of Monopolies together with the Navigation Laws and the establishment of the Bank of England became substantial preindustrial legal elements for the consolidation of the Industrial Revolution in England. ${ }^{3}$ Both the Statute of Monopolies and the Navigation Laws sought to protect and promote local industry and commerce against international competition. On the other hand, the Bank of England served as the main source of public financing for industry and commerce. Other nations viewed the English experience and adapted it to their regions. Years later, the law emerged in the United States in 1790, in France in 1791, and in Germany in 1877.

In 1873, the International Exhibition of Inventions in Vienna was marked by the absence of inventors from other countries. They feared that their inventions would be stolen and marketed in other places since there was no international law that guaranteed property and exploitation right. It should be stressed that in that period the patents were validated only within the country where they were assigned and there was no penalty for the use of third parties globally. This event was a precursor of the 1883 Paris Convention.

\section{Statute of Venice}

In 1421, during the Renaissance, the first letters patent or privilege was granted in the Republic of Florence to Brunelleschi for the design of a ship, ${ }^{4}$

3 Silvana A. Figueroa Delgado, El Estado y el trabajo científico en el proceso de DESARROLLO (Universidad Autónoma de Zacatecas 2015).

4 The privilege was expressed through a letters patent. This public document set forth the privileges granted, this being the reason why a patent is currently named "patent" to an exclusive right of an invention. Lucila Díaz Rönner et al., Propiedad Intelectual y nociones de vida: relaciones, condiciones de posibilidady desafios, 12(35) Revista Iberoamericana de Ciencia, Tecnología y SOCIEDAD 14-15 (2017), http://wwrerevistacts.net/volumen-12-numero-35/328-articulos/785-propiedad-intelectual-y-nociones-de-vida-relaciones-condiciones-de-posibilidad-y-desafios. 
and the first Patent Statute was created to protect the guilds; that is, it gave them monopoly as a tool to hinder competition. ${ }^{5}$

However, the first antecedent of the International System of Representatives was the Statute of Venice in 1474, unlike the first, considered utility, novelty and non-obviousness within its patentability requirements; it should be practical, that is, used or operated within a certain time and it was considered quid pro quo of knowledge by monopoly. ${ }^{6}$ It is known that about one hundred privileges or letters patent were granted or requested for industrial inventions between 1475 and $1550 .^{7}$ This Statute is considered by many authors as the first patent law. ${ }^{8}$

It is important to highlight the differences in the political, social, and economic context between the city of Venice and Florence that allowed the Statute to emerge in the first place and not in the second. According to Allen and Morris ${ }^{9}$, the fifteenth-century Venetian society was structured in groups, those who benefited from trade were the well-off classes with the patricians on top, an oligarchy that occupied the high command of the government and remained in their positions for a short time, and represented 2 percent of the population. In this pyramid, the cittadini originari, who held the bureaucratic positions, remained in their positions for many years and were responsible for verifying compliance with the application requirements and the granting of the letters patent. They represented 5 percent of the population. Finally, there was the popolo, which was integrated by the associations or neighborhood groups and by guilds or unions of the arts and crafts that indirectly influenced the decisions of the patricians. As the unions did not have great power to implement letters patent through their organizations, they required the State to intervene; in addition, thanks to the structuring of society and its functions, acts of corruption were limited in the process of assigning privileges, leaving income to the State.

5 G. Allen Nard et al., Constitutionalizing Patents: From Venice to Philadelphia, Review of Law \& Economics, vol. 2, No. 2, (2006).

6 Bruce Bugbee, Genesis of American Patent and Copyright (Washington, DC: Publics Affairs Press, 1964) (1967), and Giulio Mandich, Venetian Patents, 30 Journal of Patent Office SOCIETY 176 (1948).

7 Edith Penrose, La economía del sistema internacional de patentes 6 (Siglo Veintiuno, 1951) (1974).

8 Lucila Díaz Rönner et al., Propiedad Intelectual y nociones de vida: relaciones, condiciones de posibilidad y desafios, 12(35) Revista Iberoamericana de Giencia, Tecnología y Sociedad (2017), http://wrere.revistacts.net/volumen-12-numero-35/328-articulos/785-propiedad-intelectual-y-nociones-devida-relaciones-condiciones-de-posibilidad-y-desafios; Edith Penrose, La ECONOMía DEL SISTEMA INTERnACiOnal DE PATENTEs (Siglo Veintiuno, 1951) (1974); Mariano Zukerfeld, Las regulaciones del acceso a los conocimientos en el período preindustrial. Introducción a una sociología histórica de la propiedad intelectual, 17(32) REDEs, 17, 37 (2011), http://wwre.redalyc.org/pdf/907/90722371001.pdf.

9 Id. at 240-242. 
Venice became a pole of attraction for inventors, who arrived from all over the world seeking to benefit from the letters patent. This resulted in the consolidation of the Statute further in time. The unions made sure that the inventors spread their knowledge with a group of apprentices under their charge. Thus, it can be seen that the inventor had the individual right, but his exercise was of a group nature. The logic of the privilege can be understood as the monopoly years in exchange for the training period of at least two generations of apprentices, as a way of ensuring the transfer of knowledge of the immigrant teacher. ${ }^{10}$

In Florence, the unions were much stronger to offer lasting opportunities. They were governed by private norms and could grant privileges, so they did not need the intervention of the State. This way of allocation of letters patent was less expensive without state interference. Also, within the Florentine guilds, there were fewer internal interest groups that sought to oppose the innovation of each other in order to protect their inventors. ${ }^{11}$ Lastly, it should be emphasized that in Florence the guilds were the direct beneficiaries of trade, while in Venice they were all: patricians, cittadini, popolo and inventors.

It should be stressed that the patent letter was conferred for both inventions and for what is known today as copyright. There are three relevant aspects related to the Statute: first, the duration of the privilege for ten years in an invention of new arts and machines (new knowledge or imported). ${ }^{12}$ Second, requirements were established to grant the privilege; from that moment on an ordinance would replace the process that was previously a personal request; and third, the rules through a mandatory registration, which after the expiration of the patent letter would allow the transmission of knowledge to the public in favor of the economic development of the territory. ${ }^{13}$ Finally, once the right was granted, it had to be exploited, otherwise the privilege of the inventor would be revoked. ${ }^{14}$

Penrose considers that the Statute somehow helped to activate the inventive capacity "in the 15 th century the systematic use or monopoly privilege

10 Mariano Zukerfeld, Las regulaciones del acceso a los conocimientos en el periodo preindustrial. Introducción a una sociología histórica de la propiedad intelectual, 17(32) REDES, 34 (2011), http://wrere.redalyc. org/pdf/907/90722371001.pdf.

11 Frank D. Prager, The Earthly Growth and Influence of Intellectual Property, 34 (2) JournaL of the Patent Office Society, 126-128 (1950), http://wrewe.compilerpress.ca/Library/Prager\%20 Early\%20Growth\%20E\%20Influence\%20o\%20IP\%207POS\%201950.htm.

12 Samuele Romanin, Storia Documentata Di Venezia, vol. 4, 485 (Giusto Fuga, ed., 1913).

13 Mariano Zukerfeld, Las regulaciones del acceso a los conocimientos en el período preindustrial. Introducción a una sociología histórica de la propiedad intelectual, 17(32) REDEs, 26-29 (2011), http://wrere. redalyc.org/pdf/907/90722371001.pdf.

14 Alejandro García Sandoval, Derecho de patentes sobre invenciones biotecnológiCAS 5 (Universidad de Cantabria 2018). 
granted to inventors emerged in Venice in order to stimulate the invention". ${ }^{15}$ However, for Zukerfeld this ordinance intended more to protect knowledge for economic benefit of Venice, than to stimulate innovation and novelty "it seems clear that it was not of interested to create new knowledge in the territory of arrival, as much as the exploitation and dissemination of that knowledge that had demonstrated its effectiveness in other times and spaces". ${ }^{16}$

We must not lose sight of the fact that one of the reasons for granting these privileges was to preserve endogenous knowledge and capture for themselves the knowledge coming from abroad to expand their capacities, a condition that would allow them to depend to a lesser extent on foreigners.

\section{Statute of Monopolies}

Fourteenth-century England was considered the starting point of capitalism in the world with the gradual implementation of monarchical measures aimed at strengthening and protecting the internal market. This resulted in the expansion of the productive structure, the increase in regional inventiveness and the final immigration of people from Germany, Belgium, France and Italy, who were experts in the development of goods, and whose knowledge and skills were used to train and employ residents in the manufacture of products that were previously imported. ${ }^{17}$

Lipson noted that in the mid-sixteenth century and up to the first half of the seventeenth century, a state tactic was to empower an individual or a group of individuals acting as a corporation. Queen Elizabeth I, in the hands of her advisors, structured the system to grant monopolies and concessions in a discretionary manner with the objective not only to make England economically independent but also to benefit certain groups such as the same crown. This procedure gave rise to the so-called monopoly patents. Initially, four types were identified, which were the antecedents to the Statute of Monopolies. ${ }^{18}$

The first category of patents is related to the ability to invent, the intelligence or the effort of an individual discovering something beneficial for his community, to which some technical process brought from abroad is added. The second category was configured as licenses that were executed by force

15 Edith Penrose, La economía del sistema internacional de patentes 6 (Siglo Veintiuno ed., 1951) (1974).

16 Mariano Zukerfeld, Las regulaciones del acceso a los conocimientos en el período preindustrial. Introducción a una sociología histórica de la propiedad intelectual, 17(32) REDES, 31 (2011), http://wrere.redalyc. org/pdf/907/90722371001.pdf.

17 Silvana A. Figueroa Delgado ET al., La ciencia y tegnología en el desarrollo: una VISIÓN DESDE AMÉRICA (Universidad Autónoma de Zacatecas 2009).

18 Ephraim Lipson, The Economic History Of England 352-361 (A. \& G. BLACK, LTD. 1943). 
of law and prevented the production of the merchandise by an unauthorized third party. The third category was granting an individual the power to supervise an industry or commerce; for example, the wine sales. Finally, the fourth category was the concession granted to one or more persons on an industry that was in operation. Sometimes a monopoly was given within the last category derived to the first, i.e. the monopoly invention and was extended to the manufacturing process.

The monopoly of an established industry (fourth category) generated a dispute between the Crown and Parliament, because it affected the interests of the society: the monopolists set the price, the volume and the manufacturer; mostly they produced basic consumer products, which generated discomfort in the population. The bad administration and the abuses in the granting of monopoly patents showed the scarce intentions to strengthen the industry, that is, the holders of the patents benefited economically and at the same time the established industries were dismantled.

It is worth underlining that both the Crown and the Parliament had the power to grant monopoly patents. The difference is that the Crown could do so in a discretionary manner, and Parliament had to rely on the protective legislation for unions and peoples, which derived from the common law. ${ }^{19}$ Therefore, the Crown could ignore the common law for the assignment of a monopoly patent, but upon the arrival of the Monopoly Statute, both the Crown and the Parliament had to abide by the rule.

As a result of the recurring disagreements, the general discontent with the monopoly system and the pronouncement of the House of Commons, Queen Elizabeth I decided not to contradict this collective feeling of nonconformity. It was taken as a preventive measure and, facing of the possibility of irreversible consequences to her reign, the Queen issued a proclamation in 1610 in which she argued the deception under which some monopoly patents were granted, considering intervention as necessary. ${ }^{20}$

As a result of this real notification, several monopoly patents were declared without effect because they were detrimental to the common welfare. In addition to this, the most significant was the right to go to court to demand compensation for the damage caused by the use of a monopoly. Years later, this proclamation received institutional strength in the Monopoly Statute of 1624 .

The Statute of Monopolies was aimed at motivating the creativity and talent of the kingdom because in the 16th century England was surpassed by other regions as to the development of knowledge of certain industries such as mining and the manufacture of glass, paper and clothing. Furthermore, its dependence on foreign countries entailed the exit in large quantities of

19 C. Allen Nard et al., Constitutionalizing Patents: From Venice to Philadelphia, Review of Law \& Economics, vol. 2, No. 2 (2006).

20 Ephraim Lipson, The Economic History Of England (A. \& C. BLACK, LTD. 1943). 
bullion for the payment of goods (cereals, oil, leather, gunpowder, among others) purchased abroad. In this way, the Statute was expected to reduce dependence with other regions.

As mentioned earlier, the Statute declared several monopolies illegal, mainly those related to the purchase, sale, manufacture, work or use of goods, leaving only the number one category of patents in effect, and making an exception to favor inventors.

That all monopolies and all commissions, subsidies and patent letters so far made or granted, or so far for doing or being granted to any person or persons, political or corporate bodies, of or for the sole purchase sale, manufacture, work, or the use of anything with this kingdom... are completely contrary to the laws of this kingdom, and in no way should they be used or executed. ${ }^{21}$

Also, this ordinance excluded corporate or political organizations or related to them in obtaining monopolies. "And also be promulgated by the aforementioned authority, any person and persons, political and corporate bodies, who are or are subsequently, will remain and will be prevented and unable to have, use, exercise or put into use any monopoly...". ${ }^{22}$

On the other hand, numeral VI of the Statute indicated the time lapse of 14 years or less for the validity of a monopoly or concession patent, a faculty that only the true and first inventor or inventors of acts that had never been performed locally would enjoy, or have brought new knowledge from abroad.

The Statute was the strategy to strengthen the kingdom of England by promoting the development and protection of the knowledge necessary to reduce its dependence on some imported products and accumulate wealth. Penrose would point it out this way: "It was only part of the Crown's conscious policy to foster industry at the national level, which in turn was part of the overall objective of unifying the nation under a central authority, of destroying local powers and of making the country economically independent". ${ }^{23}$

One of the local powers to which Penrose alludes is the unions, which caused the backlog of innovations since they regulated the trades and marked the terms to practice them. At the same time, this ordinance is known as the law that represents all rights of the inventor, through the powers established therein in favor of the inventor and his work; not because it initiated the protection of the inventor's patent, but because it was the first general law of a modern state that established the principle that only the "true and first" inventor of a new manufacturing should be granted a patent monopoly. ${ }^{24}$

21 William Hyde Price, The English Patents Of Monopoly 136 (Boston, New York, Houghton, Mifflin, and Company, vol. I, 1906).

22 Id.

23 Edith Penrose, La economía del sistema internacional de patentes 8 (Siglo Veintiuno, 1951) (1974).

24 Id. at 10. 
It is important to note that three events that established the basis for consolidating the industrial revolution in England emerged simultaneously: the first was the Statute of Monopoly that would be granted as long as it did not transgress the public good. The second, the 1651 Navigation Law, that prohibited the importation into England by sea of goods on non-English ships. And third, the Bank of England, which was established in 1694 as the one in charge of investing in commerce through public debt. ${ }^{25}$

Protecting, rewarding and limiting inventions by the State allowed to multiply inventions without violating the public good, taking care of the domestic market, limiting maritime imports and ensuring the consumption of national products made by locals. Finally, it is worth noting that the Statute of Monopolies is the origin of the British patent law and is the precedent of the United States patent law.

\section{French Patent Law}

It can be stated that, in the case of France, the same happened as in Venice and England before the corresponding statutes were implemented: bad handling was detected in the issuance of monopoly concessions granted by the arbitrary will of the king. This method persisted, despite the vicissitudes of origin until the French Revolution broke out in 1789.

Before, France was structured by political and economic groups subject to rules decreed by the monarchy. The same acts regulated the activities of the guilds of merchants and craftsmen called "communautés". These unions enjoyed privileges that increased their impact on local economic, industrial and commercial activity. Their rules established who could exercise a craft offering protection in the exercise of their industry. In the event that an individual was not a member of the communauté, he was relegated from the exploitation of the industrial branches, and in the event of non-compliance with any norm of the union, he was penalized with high fines, confiscation or destruction of merchandise, material, and tools used in illegal industrial activity. ${ }^{26}$

All of the above is confirmed in the preamble of the Turgot edict (February 1776), registered on March 12 of the same year in the Parliament, which refers to the actions of the communautés:

In almost every city in our kingdom, the exercise of arts and crafts is concentrated in the hands of a small number of master craftsmen, gathered in communities, who alone, with the exclusion of all other citizens, can make or sell objects individuals of commerce of which they have the exclusive privilege;

25 Silvana A. Figueroa Delgado, El Estado y el trabajo científico en el proceso de DESARROLLO 24-25 (Universidad Autónoma de Zacatecas 2015).

26 Augustin-Charles Renouard, Traté Des Brevets D’Invention 42-56 (Chez Guillaumin, Libraire, 1844). 
for those of our subjects who, for pleasure or need, are destined to the exercise of the arts and crafts, they can achieve this by acquiring the domain, to which they are received only after such long tests... The simplest work often does not. It can be carried out without resorting to several workers from various communities, without eliminating the slowness, infidelities, abuses and demands or pretensions promoted by their different communities, and the vagaries of their regime, arbitrary and interested... Therefore, these establishments are, relative to the State, an invaluable decrease in trade and labor... loss of wages and livelihoods... ${ }^{27}$

It is clear that in the face of such corporate intervention, the environment did not result in a larger amount of inventions since each finding would breach any established norm or law. This is not to imply that there was no granting of privileges for the monopoly or patent letters. In fact, there were no fixed rules established on its concession, in terms of time, motive, terms, conditions, etc.; for example, the manufacture of glass, the use of a mill, the elaboration of glasses, mirrors, canons, etc. ${ }^{28}$ Sometimes because of the context, which was not very profitable and limiting for inventors, migration to other countries was an alternative to develop and generate profits from their creations. $^{29}$

By means of a declaration in December 1762, the King established for the first time norms in the matter of granting patents and inventors right. These norms, effective until 1791, were a consequence of the deficient process of granting patents, since the inventors were not rewarded and assigned, in some cases, to people who did not require them for an unlimited time for real favoritism. In addition, the lack of use of some granted privileges obstructed the freedom of others to make use of them and impeded the development of local industry.

Some contributions of the declaration were (Declaration on the Granting of Patents and Inventor Rights, Dec. 24th , 1762, art. 1-7): ${ }^{30}$

a) The privileges would be granted to private persons, in their own name or in their name and the company's, under a fixed payment and would be executed according to form and content.

27 Anne-Robert Jacques Turgot, The Turgot Collection Writings, Speeches, And LetTers 274 (David Gordon, ed., Ludwing von Mises Institute, 2011).

28 Augustin-Charles Renouard, Traté Des Brevets D’Invention 77-81 (Chez Guillaumin, Libraire, 1844).

29 This was the case of Nicholas Briot, with his pendulum machine to mark coins, who migrated to England and created there one of the most beautiful coins in the time in Europe, as well as the creator of the paper and cylinder factory who emigrated to Holland, or the inventor of the looms, who emigrated to England and obtained great remunerations, among other cases (Id. at 82-84).

30 Id. at 85-87. 
b) The enjoyment of a privilege would be for 15 years with exceptions for extension at the discretion of the Crown or Parliament according to their relevance in the respective industry.

c) In the event that a holder died in the privilege course, his beneficiaries could not inherit it until an express confirmation of the authorities (Crown and/or Parliament) was issued, as long as some requirements were met, such as their ability to carry it out, verify the clauses that integrate it in a manner and substance, etc.

d) In case of not making use of the patent or using it and not succeed within one year, it would be revoked. Only under reasons or impediments legitimately verified by the holder would this not apply.

e) The publication of the privilege for public knowledge from the granting of the privilege.

Later, the impact of this statement would be strengthened with the edict of Turgot (1776), which was intended to abolish the guilds and their excesses of authority.

The Revolution of 1789 brought changes in the organization (background and form), forming new laws and freeing the industry and trade. In 1791 there was another important modification on the law regarding useful discoveries and means of securing ownership to authors, which took as reference the Statute of Monopolies of England of 1623. The reason for these changes in the law was the need to encourage industry and stop the migration of French inventors to other nations.

In summary, the following reforms stood out (Law of Useful Discoveries and Means of Securing Ownership to Authors, Jan. 7, 1791): ${ }^{31}$

a) The invention or new discovery became a property of the author. ${ }^{32}$ This way the law guarantees full enjoyment for a certain time (Art.1).

b) The invention is considered any unknown form that is added to any genre of the industry, that is, a new degree of perfection (Art. 2).

c) He who brings a new knowledge from abroad will be considered as an inventor and will enjoy the same privileges granted by law (Art. 3).

d) Present the invention to the corresponding authority, provide the exact description, drawings, designs, etc., so that at the time of receiving the title the information may be public (Art. 4).

e) To guarantee ownership to the inventor and temporary enjoyment, a patent or title will be granted (Art. 7).

31 Id. at 111-116.

32 In the Bouliers report presenting to the Assembly a decree project dated December 30, 1790 , it was pointed out that "If there is real property for a man, it is his thought... it is personal, independent, prior to all transactions... The invention, which is the source of the arts, remains that of property: it is primitive property; all others are just conventions...". Id. at 106. 
f) The validity of a patent will last five, ten or fifteen years, this at the request of the inventor, but will not be extended unless authorized by the legislative branch. This will apply to national inventions and to inventors with inventions brought from abroad (arts. 8 and 9).

g) The inventor has the right to keep the information of his registered invention secret under justifiable reasons before the legislative branch (Art. 11).

h) The inventor has the right to license ${ }^{33}$ his invention, i.e. someone else may obtain a benefit of the invention with the authorization of the owner (Art. 14).

i) Upon expiration of the patent, the invention or discovery will enter the public domain (Art. 15).

j) The inventor will be sanctioned with the revocation of the patent, in the following cases: using secret means not detailed in the description of his patent; failing to implement the patent for a period of two years from the date of the grant, without justification; obtaining a patent in France and applying for another one with the same purpose in another country. Likewise, the licensee will be under the same obligations as the inventor (Art. 16).

In sum, the French ordinance of 1791 was based on the precepts of the Statute of Monopolies, which was the antecedent not only in France but throughout the European continent. ${ }^{34}$ The non-truth would lie in the title deed that acquires the patents, the validity, the description, the intervention of the national government for the concession and the public domain of the knowledge of the invention, since previously there was only talk of rights and privilegi or monopoly of any industrial branch that was not mentioned for the invention and it was granted to certain favorite people of the king with the support of the communautés, promoting adverse conditions for the industrial and commercial development of the country.

\section{United States Patent Law}

The signing of the 1783 Treaty of Versailles led to two events that allowed the United States to begin its process of independence. On the one hand, the indirect participation in the Napoleonic Wars as a means to supply raw materials and their dependence and connection with England, which caused economic damage, mainly due to the decrease in exports of these resources to both European countries. On the other hand, the uneven local economic evolution between the north and the south promoted by the State unleashed

33 The license was considered by law as a personal property.

34 Edith Penrose, La economía del sistema internacional de patentes 13 (Siglo Veintiuno, 1951) (1974). 
strong disputes that affected the economy. The real condition of the State at that time was critical, since it was heavily indebted. The State implemented tariff rates and established a list of duty-free products, which included primary products. ${ }^{35}$

As for patents, few were issued in the English colonies in America, because they had as a priority agricultural activity and to provide England with raw materials. They were mainly responsible for the manufacture of products marketed in other countries and in their colonies themselves, as noted by Peskin: "the lucrative manufacturing function was denied to the colonists; however, they prospered as merchants within the British Empire and gained a lot of economic influence as the most important consumers of English goods". ${ }^{36}$ Nevertheless, it was not until the Independence process that patents acquired greater importance as a source of local industrial strengthening: "it was not until the Revolution [Independence] ...that patents began to be issued in large numbers for «industrial» or inventive purposes". ${ }^{37}$

In the 1787 constitution, the United States supported the advancement of science by granting exclusive rights to authors and inventors over their discoveries "To promote the Progress of Science and useful Arts, by securing for limited Times to Authors and Inventors the exclusive Right to their Writings and Discoveries...". ${ }^{38}$ Before its independence, it was subject to the rules established in England, whose main antecedent is found in the Statute of Monopolies. Despite its separation, it did not rule out the idea of promoting the invention.

The first federal patent law derived from the Constitution was the Patent Act approved on April 10, 1790, a few years after the country's independence. This ordinance pointed out to whom, on what and for how long a patent would be granted:

TRUN And stating that he, she or they have invented or discovered some useful technique, manufacturing, engine, machine or device, or any improvement not previously known or used, and praying for a patent to be granted, therefore, will be and It may be legal for and by said Secretary of State, the Secretary of the War Department and the Attorney General, or either, if they consider the invention or discovery useful and important enough to cause

35 Silvana A. Figueroa Delgado, El Estado y el trabajo científico en el proceso de DESARROLLO 43-53 (Universidad Autónoma de Zacatecas 2015).

36 Lawrence A. Peskin, Manufacturing Revolution (Johns Hopkins University Press, 2003) cited in C. Allen Nard et al., Constitutionalizing Patents: From Venice to Philadelphia, Review of LaW \& Economics, vol. 2, No. 2, 293 (2006).

37 It is worth mentioning that after independence patents were granted by each state, that is, they did not have a national validity. This point generated a debate on validity, coverage, etc. (Allen and Morris, 2004, 297). Edgar Burke Inlow, The Patent Grant 43 (Johns Hopkins Press, 1950).

38 Constitution of the United States [Const.], Constitution Article I, section 8, numeral 8, as amended, National Archives Catalog, September 17th 1787 (U.S.). 
patent letters... enumerating the statements and suggestions of this request, and describing such invention or discovery so clear, true and complete and, therefore grant it immediately to said petitioner or petitioners, his or her, administrators or assignees for any term other than over fourteen years. ${ }^{39}$

The person responsible for executing the Law of 1790 was the Patent Board composed of the Attorney General and the Secretaries of State and War, who would be responsible for examining the patent applications and deciding to grant it based on its usefulness and importance. Three points generated debate around the Law of 1790: a) Including invention and import patents in the law. The central point was to reward the person who imported technology and knowledge to the United States, granting her recognition as the local, unique and authentic inventor; $b$ ) The conditions under which the knowledge integrated within the patent will be disclosed; c) The desirability of establishing a system to examine and register patents. ${ }^{40}$

The first point was resolved by accepting import patents, thus granting a patent on new knowledge within the territory of the United States, which could be of foreign origin. "Any person...first to import to the United States from any foreign country, any art, machine, engine, device or invention, or any improvement in this regard, not before use or known in those States, [...] will benefit fully from this act, as if it were the original inventor or improver of these States". ${ }^{41}$ In the second, it was agreed that the description would have to be specific and detailed, so that it could be distinguished from a previous one in case a new one was presented, in addition to teaching someone else the technique so that at the end of the term the public could have access to that knowledge. Finally, the implementation of a national system that would verify the usefulness and importance of granting a patent was accepted.

At the end of the 19th century, the State resumed the protective and leading role of the country's production and trade, strengthened agriculture by encouraging research and development in the sector, and granted subsidies that placed the nation in a prominent place worldwide. On the other hand, the oil industry, the automotive industry, the metallurgical industry, among others, also improved as a result of scientific and technological advances.

When the First World War broke out, the United States had an economic expansion and it became one of the main suppliers of military weapons. Then the Great Depression emerged unexpectedly. The unexpected event was taken to counteract its effects; the architect was Franklin Roosevelt who made clear the importance of the State in the leadership of a nation, Figueroa

39 Patent Act (1790), section I, April 10th , 1790, the First United States Patent Statute, First Congress. Act to promote the progress of useful Arts, $\S$ I.

40 C. Allen Nard et al., Constitutionalizing Patents: From Venice to Philadelphia, Review of Law \& Economics, vol. 2, No. 2, 305 (2006).

41 Linda Grand de Pauw, ed., Documentary History of the First Federal Congress of the United States of America: House Representatives Journal 570 (The Johns Hopkins University Press 1977). 
Delgado adds: "The economic and social viability of these actions were then confirmed: it activated both demand and production, and the State proved to be the only agent capable, within the capitalist system, of reorganizing income. The fiscal deficit came in exchange for well-being". ${ }^{42}$

Years later, World War II detonated; the United States became a supplier of warlike instruments as it happened in the first confrontation. Thus, research and development institutions for defense were created. Consequently, the state intervened establishing a link with the universities to develop new useful knowledge for the productive sector and thus maintain commercial advantages globally.

At the beginning of the 18th century, two of the most important countries in the world, the United States and France, had firmly established their patent systems; although the laws were very recent, the practices on which they were founded were ancient. The previous system of privileges had given way to another system based on statutory law. The other countries began to follow that example by establishing their national patent laws.

\section{International Patent System. Contrasts Between Laws and First Elements Towards Homogenization}

As described above, from the fifteenth century the first privileges were given through a letters patent to grant an exclusive right to exploit knowledge. From that moment to the present, the parts of the knowledge that would be eligible for patent were defined.

It should be remembered that in the Statute of Venice the privilege was granted to different types of knowledge not only to inventions, but to literary works. In addition, there were no controversies for making use of knowledge found in other nations. Each law contributed to the evolution of what is now known as patent laws (see table 3.1), the most prominent being:

a) The name patent arises from the Venice patents letter, which granted the privilege of taking advantage of knowledge for a limited time for the economy, the generation of jobs and the independence of the foreigner, also the penalty for the lack of use of the privilege given.

b) The limitation of the Statute of Monopolies in the granting of patents to the unique and authentic inventors of the invention of national origin or brought from abroad for a limited time of fourteen years, as well as other requirements to obtain the patent letter.

c) French legislation grants ownership of industrial discoveries.

42 Silvana A. Figueroa Delgado, El Estado y el trabajo científico en el proceso de DESARrollo 63 (Universidad Autónoma de Zacatecas 2015). 
d) The territorial extension of the validity of the patent right and unfair competition are integrated as part of the Industrial Property rights in the Paris Convention.

On the other hand, the process for the registration of a patent at international level is expedited in the Patent Cooperation Treaty. Roffe mentions other changes in the evolution of patent law:

The evolution of the system teaches us that patents were initially intended to reward and motivate the individual inventor, in order to improve the competitiveness of the internal industry and the industrialization process. These were the foundations of the first patent laws, for example, in countries like the United States and France. From that original conception, there were important changes. Today the great technological advances are not necessarily the result of individual works. They are the result of experiences of work teams in companies or research institutes. ${ }^{43}$

It is important to study the history of the political, economic and social conditions for which it was necessary to establish ordinances to regulate inventive activity, since knowing them allows us to understand the evolution of the international patent system, and resort to past events to predict current conflicts in the matter; as Zukerfeld points out: "In the midst of the intense current debates about possible reforms to intellectual property systems, it is likely - although in no way certain - that some novelty comes, like so many other times, from scrutinizing in the dark corners of the past". ${ }^{4}$

By doing a brief historical review, the United States is in a similar condition to that found in Venice or England several centuries ago. It has a high percentage of patent applications, in its territory and outside it. Thus, just from 1980 to 2010, the United States went from 104329 to 490226 patent applications in the form of the Patent Cooperation Treaty (PCT) ${ }^{45}$. Likewise, during the period of 1996-2010, it registered 1237060 applications for PCT patents, representing 31 percent of applications made in member countries of the Organization for Economic Co-operation and Development (OECD) ${ }^{46}$

43 Pedro Roffe, Evolución e importancia del sistema de la propiedad intelectual, 37(12) COMERCIO EXTERIOR, 1045 (1987), http://revistas.bancomext.gob.mx/rce/magazines/205/5/RCE5.pdf.

44 Mariano Zukerfeld, Las regulaciones del acceso a los conocimientos en el período preindustrial. Introducción a una sociología histórica de la propiedad intelectual, 17(32) REDES, 36 (2011), http://wrere.redalyc. org/pdf/907/90722371001.pdf.

45 Patent Cooperation Treaty [PCT], done at Washington, June 19th, 1970, amended on September 28, modified on February 3, 1984, and on October 3, 2001.

46 Raúl Delgado Wise et al., La innovacióny la migración calificada en la encrucijada: reflexiones a partir de la experiencia mexicana, 47 Remhu-Revista InTERdisciplinar Da Mobilidade Humana (2016), http://wrwre.scielo.br/scielo.php?pid=S1980-85852016000200153Escript=sci_abstractËtlng=es. 
The United States has a well-articulated educational, productive and commercial system, so experts in a wide range of knowledge areas immigrate to exploit their knowledge. Many of them conduct research or have patented their inventions, because if they did so in their country of origin, they would not have the same benefit, a condition that is used by the United States to continue capturing markets. Between 2006 and 2010 there were 205,446 migrant inventors in the world; the United States captured 57.1 percent of these. Moreover, 117,244 inventors residing in the United States were born abroad. ${ }^{47}$

The differences and similarities between the main statutes and patent laws analyzed are presented in a comparative way (see table 3.1), to highlight the process of their evolution and the first document created in this regard in the Paris Convention.

\section{Table 1. Differences and Similarities Between the Main Statutes and Laws of National Patents}

\begin{tabular}{|c|c|c|c|c|}
\hline Descriptor & $\begin{array}{c}1474 \\
\text { Venice Statute }\end{array}$ & $\begin{array}{c}1623 \\
\text { England Monopoly } \\
\text { Statute }\end{array}$ & $\begin{array}{c}1790 \\
\text { United States } \\
\text { Patent Act }\end{array}$ & $\begin{array}{c}1791 \\
\text { French Patent Law }\end{array}$ \\
\hline $\begin{array}{l}\text { Subjects who } \\
\text { receive the } \\
\text { monopoly }\end{array}$ & $\begin{array}{l}\text { Pre-Statute: fa- } \\
\text { vorites of the king } \\
\text { and guilds } \\
\text { Post-Statute: in- } \\
\text { ventor and person } \\
\text { who imported } \\
\text { new knowledge, } \\
\text { technique, etc. }\end{array}$ & $\begin{array}{l}\text { Pre-Statute: fa- } \\
\text { vorites of the king } \\
\text { and guilds } \\
\text { Post-Statute: in- } \\
\text { ventor and person } \\
\text { who imported } \\
\text { new knowledge, } \\
\text { technique, etc. }\end{array}$ & $\begin{array}{l}\text { Pre-Law: favor- } \\
\text { ites of the king } \\
\text { and guilds } \\
\text { Post-Law: inven- } \\
\text { tor or inventors } \\
\text { and person or } \\
\text { persons who } \\
\text { imported new } \\
\text { knowledge, tech- } \\
\text { nique, etc. }\end{array}$ & $\begin{array}{l}\text { Pre-Law: favor- } \\
\text { ites of the king } \\
\text { and guilds } \\
\text { Post-Law: } \\
\text { inventor and } \\
\text { person who } \\
\text { imported new } \\
\text { knowledge, } \\
\text { technique, etc. } \\
\text { and licensee. }\end{array}$ \\
\hline $\begin{array}{l}\text { Regulation of } \\
\text { rights and/or } \\
\text { obligations }\end{array}$ & $\begin{array}{l}\text { Inventions and } \\
\text { copyrights. }\end{array}$ & $\begin{array}{l}\text { Invention or } \\
\text { processes and } \\
\text { products. }\end{array}$ & $\begin{array}{l}\text { Invention of } \\
\text { processes and } \\
\text { products. }\end{array}$ & Inventions. \\
\hline $\begin{array}{l}\text { The previous } \\
\text { monopoly } \\
\text { statute/law is } \\
\text { the result of } \\
\text { social conflicts }\end{array}$ & $\begin{array}{l}\text { Conflict of na- } \\
\text { tional and regional } \\
\text { classes (patricians, } \\
\text { cittadini, popolo, } \\
\text { guilds, and inven- } \\
\text { tors) }\end{array}$ & $\begin{array}{l}\text { Conflict of } \\
\text { national classes } \\
\text { (Crown, Parlia- } \\
\text { ment, society, } \\
\text { guilds, and inven- } \\
\text { tors) }\end{array}$ & $\begin{array}{l}\text { International } \\
\text { conflict (US } \\
\text { independence, } \\
\text { protection of the } \\
\text { national indus- } \\
\text { try, world }\end{array}$ & $\begin{array}{l}\text { National and } \\
\text { class conflicts } \\
\text { (Crown, guilds, } \\
\text { inventors and } \\
\text { society) focused } \\
\text { mainly on }\end{array}$ \\
\hline
\end{tabular}

47 Özgür Topkaya, Emigration of Innovative Workforce in the Light of Patent Data, 195 ProcediA Social And Behavioral Sciences, 46 (2015), https://wrere.sciencedirect.com/science/article/pii/S1 877042815036496 . 


\begin{tabular}{|c|c|c|c|c|}
\hline & & & $\begin{array}{l}\text { positioning as a } \\
\text { war supplier in } \\
\text { World Wars I } \\
\text { and II) } \\
\text { regional social } \\
\text { conflicts (north- } \\
\text { south). }\end{array}$ & $\begin{array}{l}\text { reducing the } \\
\text { emigration of } \\
\text { inventors. }\end{array}$ \\
\hline $\begin{array}{l}\text { Does the post } \\
\text { Statute/Law } \\
\text { monopoly } \\
\text { generate new } \\
\text { conflicts? }\end{array}$ & $\begin{array}{l}\text { It privileges inven- } \\
\text { tors, guilds and } \\
\text { the State. }\end{array}$ & $\begin{array}{l}\text { It privileges inven- } \\
\text { tors and the State. }\end{array}$ & State privilege. & $\begin{array}{l}\text { Privilege to lo- } \\
\text { cal inventors. }\end{array}$ \\
\hline $\begin{array}{l}\text { Differences } \\
\text { in the dura- } \\
\text { tion of the } \\
\text { monopoly, } \\
\text { its hereditary } \\
\text { extension, } \\
\text { and denomi- } \\
\text { nation }\end{array}$ & $\begin{array}{l}10 \text { years from } \\
\text { the grant of the } \\
\text { patent } \\
\text { Name: patents } \\
\text { letter }\end{array}$ & $\begin{array}{l}15 \text { years from } \\
\text { the grant of } \\
\text { the patent. The } \\
\text { extension of the } \\
\text { patent period, the } \\
\text { transfer of rights } \\
\text { and the hereditary } \\
\text { extension prior } \\
\text { approval of the } \\
\text { authorities. } \\
\text { Denomination: } \\
\text { monopoly letter. }\end{array}$ & $\begin{array}{l}14 \text { years from } \\
\text { the grant of the } \\
\text { patent. } \\
\text { Name: patents } \\
\text { letter. }\end{array}$ & $\begin{array}{l}5,10 \text { and } 15 \\
\text { years from the } \\
\text { grant of the } \\
\text { patent. The } \\
\text { extension of the } \\
\text { patent period, } \\
\text { the transfer } \\
\text { of rights and } \\
\text { the hereditary } \\
\text { extension prior } \\
\text { approval of the } \\
\text { authorities. } \\
\text { Name: patent } \\
\text { title. }\end{array}$ \\
\hline $\begin{array}{l}\text { Justification } \\
\text { for granting } \\
\text { the monopoly } \\
\text { (natural rights } \\
\text { of the inven- } \\
\text { tor, economic } \\
\text { benefit for the } \\
\text { inventor, for } \\
\text { the country, } \\
\text { etc.) }\end{array}$ & $\begin{array}{l}\text { Natural rights of } \\
\text { the inventor: com- } \\
\text { pensation for the } \\
\text { invested work } \\
\text { Incentive for } \\
\text { national industry } \\
\text { and economic } \\
\text { growth by promot- } \\
\text { ing the immigra- } \\
\text { tion of inventors. }\end{array}$ & $\begin{array}{l}\text { Natural rights of } \\
\text { the inventor: com- } \\
\text { pensation for the } \\
\text { work invested. } \\
\text { Incentive for } \\
\text { national industry } \\
\text { through inven- } \\
\text { tions. }\end{array}$ & $\begin{array}{l}\text { Natural rights } \\
\text { of the inventor: } \\
\text { compensation } \\
\text { for the invested } \\
\text { work. } \\
\text { Incentive for } \\
\text { national industry } \\
\text { and economic } \\
\text { growth. }\end{array}$ & $\begin{array}{l}\text { Natural rights } \\
\text { of the inventor: } \\
\text { compensation } \\
\text { for the invested } \\
\text { work. } \\
\text { Incentive for } \\
\text { national indus- } \\
\text { try and eco- } \\
\text { nomic growth, } \\
\text { avoiding the } \\
\text { emigration of } \\
\text { inventors. }\end{array}$ \\
\hline $\begin{array}{l}\text { De facto } \\
\text { or de jure } \\
\text { legislation }\end{array}$ & De facto. & De facto. & De jure. & De facto. \\
\hline
\end{tabular}

SOURCE: Elaboration by author based on Penrose, 1974; Lipson, 1943; Renouard, 1840; Zukerfeld, 2011.

It is important to explain some points that are indicated in Table 3.1. The first point has to do with the arbitrariness or discretion of the competent authorities in granting the rights of privilege, letters patent or monopoly, which resulted in conflicts between different groups, mainly among those who were 
favored such as consumers and the competitors who sought to produce, use or sell the good in question.

As a second element, it is relevant to note that the duration of the monopoly varied depending on the statute/law, i.e. there were different benefits for the inventors. And also, their migration to the territories that offered them better was promoted.

Related to the duration of the monopoly, it is worth emphasizing none of the laws/statutes included clauses aimed at controlling abuses from the created monopoly. That is, the monopoly was established under the belief that it would be beneficial to boost the national industry and to protect the local market.

From the previous brief description, it is emphasized that the current patent system began by granting the first inventor the exclusivity to benefit from its creation for a certain time. As Pérez points out: "It is important to consider that a monopoly privilege was chosen at a historical moment in which a large part of the incipient manufacturing production was carried out under the monopolistic supply system for the so-called guilds". ${ }^{48}$ That is, the patent was used to strengthen and economically promote a region, as well as recover the investment made by the creator in the development of the invention. Furthermore, the inventor was informed that in case he failed to exploit the exclusivity, this would be lost.

In England, the Statute of Monopolies was established to stop the abuse of the Crown in the granting of monopoly letters to its favorites, because the growth, development and general welfare of the population was limited. The public interest won against the Crown and private interests. To date, within the industrial property rules of that country, there are still traces of the Statute of Monopolies that follow the same line as the Statute of Venice, stimulating the industry through legal mechanisms to grow inside and compete in the foreign market.

From the 18th century Patent Law of France the character of property acquired by intangible assets such as copyright and patents stands out, as they were a movable or immovable property. This item, "industrial property", as well as the monopoly of patents, has been and continues to be a point of debate due to its legal and economic nature, as well as its benefits and consequences in national, regional and international market-trade development.

The current legal figure of the patent remains within the industrial property right, that is, it is still considered a property of an intangible asset. Unlike the granting by the State or the Crown, a patent is currently granted to that or those (speaking of a legal entity) that meet the requirements requested by the institutions, regardless of whether or not they are the single authentic

48 Rafael Pérez Miranda, Patentes, monopolio y competencias. El Caso de los productos farmacéuticos, PPropiedad intelectual y farmacéuticos; Hacia una política de Estado, Patentes, 180 (Instituto de Investigaciones Jurídicas, 2013). 
inventor. Likewise, it has an exclusive monopoly over a product or process for a certain time. And it is a case of monopoly because it limits exactly a third party to make use of the knowledge concentrated on a patent under the authorization and protection of the state.

Pérez Miranda ${ }^{49}$ mentions that precisely the monopoly represents one of the greatest problems of patents in our days due to the abuse it has generated. Consequently, agreements such as TRIPS, which are a reference for national laws on intellectual property for its signatories, establish the option of Compulsory License to curb exploitation excesses. However, the main industrialized countries, members of the World Trade Organization and also signatories of the TRIPS have not been flexible enough to the compulsory licensing system and have opted for internal antitrust laws, as is the case in the United States.

On the other hand, Pérez Miranda ${ }^{50}$ points out that we must be cautious with the interpretation of the term "abuse" as from a subjective perspective having a price of a patent drug higher than its average would be considered abuse even though the strictly legal vision would be to make valid a right of exploitation granted by the State.

Esplugas $^{51}$ makes a critique of intellectual property in its ethical-philosophical foundations and the utilitarian argument in its economic nature. Similarly, he points out that in the case of the patent and the copyright, they start from what in economics would be deemed very scarce, which limits or excludes the use by another subject or for another purpose. Both legal figures create an artificial shortage backed by the state through laws. Cole ${ }^{52}$ notes that the purpose of intellectual property is to generate scarcity through a legal monopoly. In the case of the patent, the law guarantees its holder a monopoly to obtain a profit.

The foregoing is contrary to the discourses that promote the creation of intellectual and industrial property laws that deal with guaranteeing the exclusivity of exploitation to inventors as compensation for effort, time, dedication, resources, among others. Likewise, some States, institutions, and international organizations argue that these legal tools encourage innovation, industrial strengthening, economic growth and the ability to compete in the global market.

49 Rafael Pérez Miranda, Tratado de derecho de la Propiedad industrial, 108 (Porrúa ed., 2011).

50 Rafael Perez Miranda, Patentes, monopolio y competencias. El Caso de los proDUCTOS FARMACÉUticos, PROPIEDAD INTELECTUAL Y FARMACÉUticos; HaCia UNA POLÍtica de EsTADO, PATENTES, 186 (Instituto de Investigaciones Jurídicas, 2013).

51 Albert Esplugas, El monopolio de las ideas. Procesos de Mercado, Revista Europea de Economía Política, volumen III, Número 1, primavera 60 (2006).

52 Julio H. Cole, Patents and Copyrights: Do the Benefits Exceed the Costs? Journal of LiBertarian Studies, 15 (4), 79-105 (2001) cited in Albert Esplugas, El monopolio de las ideas. Procesos de Mercado, Revista Europea de Economía Política, volumen III, Número 1, primavera 60 (2006). 
It should be noted that discussions about the ownership of intangible assets and the monopoly of patents have been a constant fact. This document only mentions some ideas or currents that address several elements that circulate around the international patent system, such as monopoly, property, quality, and nature.

Since national laws stipulated various guidelines, the Paris Convention sought to articulate general and common criteria. According to Perez Miranda ${ }^{53}$ and Penrose, ${ }^{54}$ these were the following:

a) The separation of the moral and economic law: moral law or public recognition as the inventor and economic or patent title.

b) Despite industrial and commercial differences, all countries will have equal treatment: "national treatment".

c) Duration of 20 years from the first patent application: right of priority.

d) The territorial validity of the patent is guaranteed in the member countries of the Union and in which it has been requested.

e) It covers patents, trademarks, industrial designs, industrial secrets, geographical indications and unfair competition.

f) The patent cannot be extended beyond the 20 years indicated.

g) Patents applicants can be both individuals and corporations.

h) The revocation of a patent will depend on each national law where the registration takes place.

i) International litigation is admitted for unfair competition; they can be carried out in a multilateral manner and the Union acts as an arbitrator.

j) It opens the possibility of migrating knowledge (as someone's property) and not a person; that is the importation of the owner or objects manufactured to other countries of the Union does not merit patent revocation.

$\mathrm{k}$ ) The principle of independence is established, that is the concession in one country does not require another to grant it. In addition, the denial of a patent in one country does not imply denying it in another.

l) The conditions of "abuse of the exercise of a patent" are established. Non-exploitation can only be sanctioned with compulsory non-exclusive license, it is requested after four years of the deposit of the application or three years after the granting of the right, whichever expires later, and only if the holder had not begun the exploitation two years after the first compulsory license was granted, can the expiration be decreed.

53 Rafael Pérez Miranda, Tratado de derecho de la Propiedad industrial (Porrúa ed., 2011).

54 Edith Penrose, La economía del sistema internacional de Patentes (Siglo Veintiuno, 1951) (1974). 
In the following section, the context in which the Paris Convention is established will be developed in greater depth and the most important changes will be explained in greater detail.

\section{International Patent System. A New Turn}

In the nineteenth century, the trend of the laws on industrial property legislation had spread. However, certain interest groups, traders, industrialists focused on exports, lawyers, etc., hoped to achieve territorial extension of rights exclusive of patents outside their borders, as well as the establishment of penalties for unfair competition, since it was thought that if they did not do so, they would be in a state of commercial disadvantage and the development of inventive ability would be hindered.

In 1884 the Convention of the Paris Union emerged for the protection of Industrial Property. It was formed by 79 countries and was known as the World Intellectual Property Organization (WIPO). ${ }^{55}$

\section{Establishment of the Paris Convention}

After 1815, the commercial and economic activity of the West increased exponentially. There were also advances in the arts and crafts; in industrial activity, trade ties between countries were similarly strengthened. Consequently, cooperation between nations regarding finance and the patent system was imperative. Nevertheless, two ways of thinking about these issues emerged. On the one hand, the highly active industry meant that creators demanded greater protection for their inventions. On the other hand, the consequences of adopting a repressive and monopolistic patent system for some less-developed nations, for example Latin American ones were argued by Penrose. ${ }^{56}$ Indeed, the discussion continued for a longer time, but in the end, the idea of implementing national and international patent laws prevailed.

In relation to national patent systems, by the nineteenth century several European countries, namely Russia, Prussia, Belgium, Holland, Spain, France, England, Germany, among others, had their own patent law. However, in 1873 the importance of the territorial scope of patents became evident, as a result of the Vienna Universal Exhibition. The United States was the first nation to express its opinion on the adverse effects that it would cause to appear in an international exhibition without protection of its inventions or products. Within the own nation, these were under its care, but outside, they were threatened by imitation and a probable commercial disadvantage. In

\footnotetext{
55 Id. at 54-57.

56 Id. at 16.
} 
addition, the country stressed that both national and international laws were necessary. As a result, subsequent meetings were held that culminated in an agreement in Paris in 1883 initially signed by thirteen nations, including four Latin American countries, of which only Brazil has remained constant from the beginning. ${ }^{57}$ The validity and stability of the Convention have allowed it to be the benchmark for the development of national patent laws, but all member nations have the freedom to articulate their laws under their own interests based on common principles.

The Paris Convention integrates several types of industrial property, as it refers to patents, trademarks, industrial designs, utility models, trade names, geographical indications and unfair competition. Furthermore, in general, the provisions contained herein are divided into four important areas: national treatment, right of priority, common rules and abuses in the exercise of the patent right.

National treatment refers to the equal rights and obligations that a foreign patent will obtain, such as a national patent, that is to say, a signatory country may register a patent in another nation and will receive the same treatment as its nationals. ${ }^{58}$ And in relation to countries not integrated into the Agreement, provided they have an industrial and commercial domicile in a member country the applicant must consider the requirements demanded by each national or regional office, in order to carry out its procedure, as are the cases of the United States Patent and Trademark Office (USPTO) and the Patent Office of Japan (JPO), those with differences in their processes, times and requirements.

Regarding the right of priority, any industrial property application submitted by a signatory country in the national institution may extend the request to other member countries according to their interests, taking as the date of application the first date of submission of this. This means that a Subsequent request will be a priority over other requests submitted by others interested likewise ${ }^{59}$ However, despite having the right of priority, it is of utmost importance to have extensive knowledge about the compliance of deadlines when to make it valid.

Finally, from the 1883 Paris Convention, some common rules are established which all the contracting states are obliged to respect and enforce. Some examples are: a) The granting, denial, cancellation, among others, of a patent will depend on each contracting country, which means that member nations are not obliged to submit to the decisions of another country; $b$ ) it is the right of the inventor to be named as such in the patent. In comparison with the Statute of Monopolies, it is not specified here that the patent will be

57 Pedro Roffe, Evolución e importancia del sistema de la propiedad intelectual, 37(12) COMERCIO EXTERIOR, 1041 (1987), http://revistas.bancomext.gob.mx/rce/magazines/205/5/RCE5.pdf.

58 Paris Convention for the Protection of Industrial Property, March 20, 1883.

59 Id. 
granted to the sole and authentic inventor, the granting of a patent as its legitimate right, since only the moral right but not the economic right over the patent is highlighted; c) if the sale of the product of a patent is limited by national legislation, this will not be grounds for responding negatively to a patent application or invalidating an existing one; and $d$ ) member countries have the right to establish in their legislation the granting of compulsory licenses. ${ }^{60}$ However, they will do so considering certain circumstances, for example:

The lack of industrial exploitation or insufficient exploitation of the patented invention, when the application has been submitted after three years from the grant of the patent or after four years from the date of filing of the patent application. In addition, the application must be rejected if the patent holder justifies its inaction on legitimate grounds. Moreover, the expiration of the patent cannot be foreseen except for the case in which the granting of a compulsory license would not have been enough to prevent abuse. ${ }^{61}$

This Convention adopted in 1883 had six subsequent revisions and suffered some final changes in the year 1979; the above allowed the territorial expansion of the exclusive right to an invention or other branches of industrial property, as well as the specifications on unfair competition. Currently, there are over one hundred member countries. The international body created to administer the Agreement among other Treaties is the World Intellectual Property Organization (WIPO).

The discussions that took place in the subsequent Conventions were related to I) the right of priority that implies that the inventor can register the patent in any member country of the Union as the sole inventor; II) the abuse of monopoly, specifically in relation to obligatory work and compulsory license; III) national treatment for foreign and national patents and IV) the independence of patents. ${ }^{62}$ It is necessary to clarify that the countries that signed the Convention may or may not at that time have national patent laws that would indicate such clauses; the United States had the most favorable national legislation for inventors, nationals or foreigners.

The obligatory work and compulsory license clauses generated major controversies. On the one hand, some people defended the protection and impulse to their national industries, while others proposed that the elimination of obligatory work would benefit even more the nascent industries.

...The work requirement may be indispensable for one nation, but unnecessary for another, and it is for this reason that there are so many differences of opin-

60 Compulsory licenses are those granted by a national institution, without considering the opinion of the patent owner. Somehow, it is expected to prevent the abuse of exclusive rights.

61 Paris Convention for the Protection of Industrial Property, March 20, 1883.

62 Edith Penrose, La economía del sistema internacional de patentes 85-86 (Siglo Veintiuno, 1951) (1974). 
ion regarding the usefulness of this type of patent system...in countries where the industrial activity is still in childhood, the requirement of compulsory labor is indispensable for the development of the national political economy and for the training of a professionally qualified workforce. ${ }^{63}$

In general, mandatory clauses have proven that they are inadequate to carry out the intention of legislators to promote national industrial activity. The long-standing experience of foreign countries indicates an extremely rickety use of compulsory exploitation... ${ }^{64}$

The tendency was in favor of eliminating obligatory work and for the benefit of the establishment of compulsory license. In addition, each nation established in its national laws whether or not the clauses that counter-monopoly abuses were approved. ${ }^{65}$

Finally, it is worth noting that this Agreement had several indications, which were established under a false principle of reciprocity since it operates on the equality of the parties. However, there are differences in economic capacity and technological development between the signatory countries and the possible applicants, implying that there is an immense application for patents from developed countries in underdeveloped countries, and in comparison to nationals. The exclusivity of excessively long exploitation discourages other researchers from searching on their own means the technology carried out by another researcher, since this effort is of no use. This also applies to fewer industrialized countries, which will stop conducting research in areas where more developed countries carry out research and development, given that their capabilities and level of development will allow them to obtain late successes. ${ }^{66}$

\section{Formation of the Patent Cooperation Treaty}

There is another important agreement in the International Patent System, the Patent Cooperation Treaty (PCT), signed by eighteen countries in June 1970 in Washington, D.C., and it entered into force eight years later. To date, there are 152 contracting countries. This treaty determines a system to

63 A. J. Michel, Introduction to the Principal Patent System of the World 10 (New York, 1936), mentioned in Edith Penrose, La economía del sistema internacional de patENTES 142 (Siglo Veintiuno, 1951) (1974).

64 Richard Reik, Compulsory licensing of patents, 36 (5) The American Economic Review, 815 (1946), mentioned in Edith Penrose, La economía del sistema internacional de patentes 149 (Siglo Veintiuno, 1951) (1974).

65 Edith Penrose, La economía del sistema internacional de patentes (Siglo Veintiuno, 1951) (1974).

66 Rafael Pérez Miranda, Tratado de derecho de la Propiedad industrial, 45-46 (Porrúa ed., 2011). 
submit applications in different PGT signatory nations, through a single application. ${ }^{67}$ As mentioned, at the end of the PCT process each country will determine whether the application and/or grant of the patent are appropriate, through its patent offices.

The International Office in charge of WIPO coordinates and administers the PCT system, and also feeds on user experiences to improve its performance.

The phases of the PCT procedure are as follows: ${ }^{68}$

\section{International phase}

1) Submission of the PCT application.

2) International search report and written opinion.

3) International publication.

4) Supplementary international search (optional).

5) International preliminary exam (optional).

\section{National phase}

The processing of PCT application before the national or regional patent offices.

The first stage of the international phase begins with the filing of a local application at a national or regional patent office, and then the PCT application is made. There is a limited time of 12 months to submit it, from the local application, at the same national or regional office or if it is preferred, the presentation can be made directly at the WIPO Office.

Sixteen months after submitting the local application, the applicant receives an international search report and a written opinion from the Administration to whom the task is entrusted. The report contains quotations of patent documents among other relevant information related to probable patentability; this is accompanied by a written opinion that is a preliminary evaluation of the invention.

The third stage consists of the publication of the PCT application after eighteen months from the priority date in the PATENTSCOPE database

67 Occasionally it is confused that this Agreement collaborates with the filing of an application in different signatory countries with the granting of an international patent. WIPO only collaborates in the application process, but does not grant a patent with global validity. The single PCT application reduces time, money and effort of applicants, inventors or national offices in the application of a patent in each of the countries in which there is an interest in patenting. It is an international simplified presentation.

Organización Mundial de la Propiedad Intelectual, Introducción al Tratado de Cooperación en Materia de Patentes (2018).

68 Patent Cooperation Treaty [PCT], done at Washington, June 19, 1970, amended on September 28, modified on February 3, 1984, and on October 3, 2001. 
managed by the International Bureau. ${ }^{69}$ The technical part of the invention is revealed and, as of this moment, the applicant usually begins negotiations for industrial production, marketing, etc.

The applicant has the power to request at any time, before twenty-two months from the priority date, an additional report by another Search Administration. If your right is valid, there must be a supplementary international search report, and the applicant has the power to request an additional report from another Administration. The report will be ready within a period not exceeding twenty-eight months from the priority date. Also, a preliminary examination can be managed under the same terms and conditions as the report. This will allow the applicant to be more certain of the patentability of the invention and may make modifications to the PCT application with information from the report and/or preliminary examination.

The Administration responsible for the international preliminary examination shall forward the report to the national or regional Patent Offices for them to conduct patentability evaluations of the invention. With this stage, the international phase of the PCT application procedure is terminated.

On the other hand, the applicants at the end of the international process will make an indication of the countries in which they intend to register a patent, thus initiating the national phase. With the report made by the responsible Administration, each national or regional Office will assess, based on its laws, regulations and practices, the granting of the patent.

Once the national patent has been granted, any interested party has the right to object, appeal or request the revocation of the patent. Or in the case of the patent holder, it can promote infractions to users for the improper use of a patented invention or it can grant licenses from its patent.

\section{Intellectual Property and International Trade}

The establishment of the international patent system was largely driven to protect and promote international trade in the first half of the twentieth century. A group of countries agreed that it was necessary to reduce tariffs and trade barriers, since it was intended to open the range of business opportunities for stakeholders. In 1941, the first test was carried out with the endorsement of the Atlantic Charter in which the free exchange of goods and equal treatment for the signatory members was agreed. Another effort was the Havana Charter created to restore the economy and commerce of countries affected by military conflicts, as well as the formation of an International Trade

69 Regarding dates, there are several examples, such as the priority date, which is the date taken from the request made at the national or regional office, the local request. In addition, the date of submission of PCT application for the process and its stages will always be considered the priority date, the date of the local application. Likewise, there is the date of denial or withdrawal and an expiration date. 
Organization. This was done within the framework of the World Conference on Trade and Employment, but the work was in vain since they did not reach concrete agreements. However, in 1947 the idea was resumed in Geneva, and this time the negotiations concluded with the signing by 23 nations of the General Agreement on Tariffs and Trade (GATT) ${ }^{70}$ which entered into force in January 1948 through a Provisional Application Protocol..$^{71}$

The GATT at that time lacked full action, as well as legal personality at an international level since it required an organizational structure. Over time and with periodic work meetings, ${ }^{72}$ results were achieved on the issue of tariffs. In the last round of Uruguay, 1986-1994, tariff issues, subsidies, anti-dumping codes were addressed, referring not only to products but also to services and the resolution of disputes between countries. It should be stressed that in this meeting the topic of intellectual property was approached for the first time from a commercial perspective. On the other hand, the World Trade Organization (WTO) was created within the resolutions of that meeting ${ }^{73}$ through the Marrakech Agreement of 1994.

Most of the Agreements administered by the WTO are based on basic principles: most favored nation (MFN), equal treatment for all members and national treatment, equal treatment for nations and foreigners. ${ }^{74}$

The relationship between WTO and WIPO is agreed in the Cooperation Agreement between WIPO and WTO in 1995. This agreement aims to enforce Conventions that validate Intellectual Property Rights; as well as intellectual property rights with commerce, for example, the TRIPS, ${ }^{75}$ Paris Convention, Berne Convention, Rome Convention and Intellectual Property Treaty regarding Integrated Circuits, among others.

On the other hand, the cooperation between WIPO and WTO includes notices of national laws, the application of international TRIPS precepts based on the sixth article of the Paris Convention.

70 The General Agreement that date contained 35 articles relating to tariff concessions.

71 Organización Mundial del Comercio, Los años del GATT: de la Habana a Marrakech, OMC (2019), https://wwwewto.org/spanish/thewto_s/whatis_s/tif_s/fact4_s.htm.

72 Work meetings were called rounds. In total, eight rounds were held: Geneva in 1947, Annecy in 1949, Torquay in 1951, Geneva in 1956, Dillon in 1960-61, Tokyo in 1973-1979, Uruguay in 1986-1994, see https://wwwewto.org/spanish/thewto_s/whatis_s/tif_s/fact4_s.htm\#rounds.

73 The Organization entered into force in January 1995. It is responsible for regulating commercial activity between countries and managing the diversity of trade agreements signed between nations, for example the General Agreement on Tariffs and Trade (GATT), the General Agreement on Trade in Services (GATS), the Agreement on Trade-Related Aspects of Intellectual Property Rights (TRIPS). Additionally, within the multiple tasks of the WTO is the trade policy review, consisting of, as the name implies, a study of the members' trade policies, for they must be promoted within the framework of transparency. This study estimates the importance of its application. It is the obligation of the members to undergo constant evaluation.

74 See https://wrww.wto.org/spanish/thewto_s/whatis_s/tif_s/fact2_s.htm.

75 Some of the treaties not covered by TRIPS are the WIPO Copyright Treaty, WIPO Treaty on the Interpretation and Execution of Phonograms, Brussels Convention. 


\section{Agreement on Trade-Related Aspects of Intellectual Property Rights (TRIPS)}

The Agreement is administered by the WTO, and it contains elementary rules that must be followed. It includes national laws on intellectual property of the member countries of the WTO-both copyrights contemplated in the Berne Convention ${ }^{76}$ and industrial property considered in the Paris Convention. The agreement increases the validity term for patents, expands their scopes of action and indicates the time of publication of inventions that required patent registration. Some of the main changes introduced by the TRIPS agreement are: the legal duration of patents should not be less than 20 years from the application; patents must cover all fields of technology (including drugs that were previously excluded in a series of countries). Patents must be published 18 months after the priority date. ${ }^{77}$ Finally, for the resolution of disputes, the signatory countries may resort to the WTO dispute settlement. ${ }^{78}$

Jorge separates in two groups the precepts contained in the TRIPS to carry out his study, specifically, in the matter of patents: a) the first group integrated the dispositions that have the determination to reinforce the right of the patent holder, and b) the second consisted of those that protect the consumer, in addition to promoting technology transfer. ${ }^{79}$

The first group refers to the duration of a patent (article 33), the susceptibility of an invention to patent (article 27), the rights granted (article 28) and national treatment (article 3). The second cites the mandatory conditions for patent applicants, exceptions to the rights granted, compulsory licensing modalities, as well as the transition periods, that is the time that countries have to incorporate these agreements into their national laws.

The exceptions to the patentability criteria of TRIPS 80 are found in articles 27, paragraph 2, subsection a and b, and article 30, which indicates the Bolar exception, ${ }^{81}$ allows researchers to use a patented invention in their

76 The Berne Convention was signed on September 9, 1886. It is administered by WIPO and by the members of TRIPS.

77 Organización para la Cooperación y el Desarrollo Económicos, Manual de Estadísticas de Patentes de la OCDE 53 (OCDE-Ministerio de Industria, Turismo y Comercio-Oficina Española de Patentes y Marcas 2009).

78 Rafael Pérez Miranda, Tratado de derecho de la Propiedad industrial (Porrúa ed., 2011).

79 María Fabiana Jorge, Generación y protección del Conocimiento: propiedad inTELEGTUAL, INNOVACIÓN Y DESARROLLO ECONÓMICO 201-209 (Comisión Económica para América Latina y el Caribe 2008).

80 Agreement on Trade-Related Aspects of Intellectual Property Rights, [TRIPS], April 15, 1994).

81 The Mexican government approved the exception of Article 30 of the Agreement, an action reflected in Article 25 of the Industrial Property Law and addition of Article 47bis to the Regulations of the Industrial Property Law, which is complemented by the Decree 
research to get to know it better (in the case of generic drugs that carry out studies or clinical trials) so that at the end of the exclusive time they can use that knowledge ${ }^{82}$ and take actions to counteract anti-competitive practices in Articles 8 and 40. Similarly, compulsory licensing consists of authorization given by the government for the manufacturing of a product or the use of a patent process with the permission of the holder of the patent, based on Article 31 of the Agreement in question. The Bolar provision seeks to protect the interests of less developed nations. However, it is the responsibility of each legislator at the national level to contemplate the mechanisms to access these benefits in their intellectual property laws.

It is possible to say that the Agreement decrees the correct application of the elementary principles of the system of commerce and international agreements in the matter of Intellectual property. The basic protection revolves around the following elements: to provide appropriate protection to those of intellectual property rights and the resolution of disputes among the members of the World Trade Organization in a multilateral manner.

On the other hand, it should be stressed that, within the negotiations, the integration of exclusivity periods of test data (or clinical trials) was discussed, to avoid making known the process of elaboration of some invention for a certain time. For example, this modality would help the pharmaceutical industry to retain information to avoid being reproduced by any generic pharmaceutical industry. Another point of controversy was the protection of pipeline patents. ${ }^{83}$ Both of the issues were dismissed. ${ }^{84}$

Within the Doha Declaration, specifically in the sixth paragraph, the TRIPS Council was ordered to find a prompt alternative to the public health problem. As a result, it was agreed to change some provisions of TRIPS to approve the export and import of medicines produced under a compulsory license. However, the compulsory license only applies in case of a national emergency. The country will have to specify what a national emergency is,

published in the Official Gazette of the 2003 Federation, for which Article 167 bis was added to the Health Supplies Regulation. See http://wwercwipo.int/export/sites/wrwro/scp/en/meetings/session_23/comments_received/mexico.pdf, also http://dof.gob.mx/nota_detalle.php?codigo $=690516$ Gfecha $=$ 09/19/2003, which is still valid to date, see http://wererc.ordenjuridico.gob.mx/Documentos/Federal/ pdf/wo88318.pdf.

82 This process can be carried out by the generic drug industries three years before the patent expires with the support of its national legislation, this without the authorization of the patent holder, with the aim to carry out the procedures for the future commercialization of its products, see https://werere.proceso.com.mx/357431/la-guerra-de-los-medicamentos-2.

83 Also called patent revalidation, which has a relationship with an original patent that expires in the country of origin, that is, if the patent has already expired in the country of origin, it cannot be applied for another 20 years in another PCT member country where the patent had not been requested.

${ }^{84}$ In the case of Mexico, the Industrial Property Law did not contemplate the non-revalidation of expired patents in other countries. This was mentioned with post-law reform in transitory number 12 of the Law. 
and only a domestic demand will be met and will have to pay the patent holder. All this has to be clearly specified in National laws, since if it is not; it could enter into some international controversy. This modification entered into force in 2017.85

Finally, it should be noted that the TRIPS Agreement sets the basic provision of the Intellectual Property of international observance. However, in the signing of a Free Trade Agreement, they can be further specified and limited.

\section{Free Trade Agreement}

The TRIPS Agreement is considered the first reference that integrates Intellectual Property with a commercial link. In addition, it is the reference to expand, create or modify national laws that agree with the international common agreements in the matter. Nevertheless, for the practical purposes of defending the interests of the industries that frequently use Intellectual Property (software, audiovisual and pharmaceutical industries), this Agreement is not sufficient, since it is general, flexible and dispute resolution, under multilateral consultations.

Through the Bolar exception in the TRIPS, any interested person can access clinical trials prior to the expiration of the patent. The above is useful mainly for the generic of the pharmaceutical industry since it allows them to enter the market at the end of the validity of a drug patent. The pharmaceutical companies that held the patent considered that this flexibility affected their interests and advocated the extension of protection of this information. ${ }^{86}$ The clinical studies meet the requirements of the country's sanitary regulations and have no direct relationship with the right of ownership of the patent itself, but it is necessary to comply with these standards for the manufacture, sale and distribution of medicines. ${ }^{87}$

Given this scenario, through the United States Office of Commerce, the software, audiovisual and pharmaceutical industries, were one of the main promoters of the establishment of bilateral free trade agreements that specify in greater detail trade, investments, intellectual property, among others, in order to ensure the interests of its representatives, the big industry.

Free trade agreements can define and specify, through articles or clauses, aspects related to commercial transactions, such as tariffs, participating industries, intellectual property, investments, and dispute resolutions. What

85 Ministerial de la Organización Mundial del Comercio [O.M.C.] (DOHA, 2001): Declaración Ministerial WT/MIN (01)/DEC/1, Nov. 20th, 2001, https://wrere.wto.org/spanish/ therwto_s/minist_s/min01_s/mindecl_s.htm.

86 Álvaro Díaz, América latina y El Caribe: la propiedad intelectual después de los TRATAdos de Libre COMERcio 75 (Comisión Económica para América Latina y el Caribe, 2008).

87 Rafael Pérez Miranda, Tratado de derecho de la propiedad industrial (Porrúa ed., 2011). 
makes these agreements a detailed legal tool that can be useful or harmful for the signatories is whether there are equal conditions between the signatory countries, or whether infrastructure, labor, primary resources or broad legal knowledge can have negative consequences such as deepening the technological dependence, which can prevent national industries from developing.

The Free Trade Agreement with North America (NAFTA) links for the first time foreign direct investment to intellectual property. It contains a chapter dealing exclusively with the issue of Intellectual Property, it states that intellectual property is integrated into investments explaining that "investment means: ...(g) real estate or other property, tangible or intangible, acquired or used for the purpose of obtaining an economic benefit or for other business purposes". ${ }^{88}$ In addition, within the Fifth Part called Investment, Service and Related Matters, of Chapter XI, article 1110, it indicates in general terms aspects that contravene the Compulsory License established in the TRIPS Agreement. That is, a contracting State may not use its rules to apply for such a license, nor may it make use of any type of expropriation and/or nationalization of any kind of intangible property by any investor (this includes patents).

The foregoing shows that beyond seeking to encourage the national invention for development through these mechanisms, what is intended is to ensure the investments of companies in intangible assets within the countries with which they establish these treaties, generating disadvantages for countries with low scientific, educational, industrial, commercial development.. In fact, Pérez Miranda mentions that intellectual property rights have evolved from encouraging inventions to be a stimulus for investment. ${ }^{89}$

Finally, it should be noted that another central point of the free trade agreement is the means of resolving disputes or disputes in matters of intellectual property. Given the above scenario, in addition to the hierarchical superiority acquired by these agreements over national laws, it is possible to incur in faults not only in intellectual property but also to attempt an investment, which would lead to two different processes before different authorities. It is worth mentioning that this is the case of several countries in Latin America. ${ }^{90}$

\section{Regional Economic Integration in South America}

The Cartagena Agreement (1969) is a juridical instrument signed by the Andean countries of Bolivia, Colombia, Chile, Ecuador, and Peru; in 1973 Venezuela joined the Agreement while in 1976, Chile retired from it. According to article 1 the agreement aims.

88 North American Free Trade Agreement [NAFTA], Chapter XVII, Chapter XVI, article 1139, as amended, Diario Oficial de la Federación [DOF], Dec. $20^{\text {th, }} 1993$ (Mex.).

89 Rafael Pérez Miranda, Tratado de derecho de la Propiedad industrial (Porrúa ed., 2011).

$90 \quad$ Id. at 68. 
...to promote a balanced and harmonic development of the member countries, through the integration and economic and social cooperation; accelerating its growth and the creation of employment; facilitating its participation in the process of regional integration, to gradually formed a common Latin American market.[It also seeks] to diminish external vulnerability and improve the position of the member countries in the international economic context. ${ }^{91}$

In 1997 this group of nations changed its structure and name to Comunidad Andina de Naciones (CAN) [Andean Community of Nations]. The CAN has a common law on intellectual property rights:

1. Common Regime of Industrial Property is established in the Decisión 486, which norms granting trademarks, designations of origin, invention patents, industrial designs; and also protects industrial secrets, test data, unfair competition linked to industrial property, among others. ${ }^{92}$

2. Common Regime on copyrights and Related Rights embodied in the Decision 351 that recognizes adequate protection for authors and other rights holders over works of inventiveness in the literary, artistic or scientific filed whatever the genre of form of expression and regardless of literary or artistic merit or destination. ${ }^{93}$

3. Common Protection Regime to Rights of Plant Variety Breeders set up in Decisión 345 that protects the new plant varieties obtained by plant breeders. In the Andean sub-region, people who have created or obtained a new plant variety through the application of scientific knowledge enjoy the exclusive right to produce and commercialize said plant for a period of twenty-five years. ${ }^{94}$

4. Common Regime on Access to Genetic Resources embodied in $D e^{-}$ cision 391 that regulates the obtaining and use of genetic resources for a more fair and equitable participation in its benefits. The community norm expressly recognizes the rights that indigenous, African-American and local communities have over their traditional knowledge, innovations, and practices associated with genetic resources and their derived products. ${ }^{95}$

It is worth to mention that Decision 486 replaced Decision 344 in the year 2000 and that its amends were oriented to incorporate significant aspects stipulated on the TRIPS, such as national treatment, the most favored na-

91 Acuerdo de Integración Subregional Andino (Acuerdo de Cartagena), May 26, 1969.

92 Decisión 486 Régimen Común sobre Propiedad Industrial, September 6, 2000.

93 Decisión 351 Régimen Común sobre Derecho de Autor y Derechos Conexos, December 17, 1993.

94 Régimen Común de Protección de los Derechos de los Obtentores de Variedades Vegetales, October 21, 1993.

95 Régimen Común sobre Acceso a los Recursos Genéticos, July 2, 1996. 
tion treatment, the scheme of layouts of integrated circuits - referred to the treatment of "microchips" - and the observance of border measures that will result in greater piracy control. It also changed towards a more agile and transparent procedures in registering and granting of trademarks and patents. This common regime is supplementary to current national law in the matter, that is, every country could have a national law on Intellectual Property Rights (IPRs).

Additionally, it is important to highlight that it went beyond the TRIPS, since it incorporated biologic and genetic heritage and the knowledge of indigenous, African American and local communities, as knowledge potentially patentable previous authorization of them using as reference the Biological Diversity Act (2002). ${ }^{96}$ Regarding this last aspect, there are some concerns about patenting traditional knowledge instead of regulating it by customary law, since in these countries there is a customary law at a national level that considers the active participation of indigenous peoples while it cannot be guaranteed at the regional level through the Decisión 486. ${ }^{97} \mathrm{Also}$, there are implications of the appropriability of this knowledge once a patent is granted in favor of great corporations and in detriment of the population in general and specifically of these indigenous peoples.

Of these Andean countries, in 2016, Ecuador issued a new law on IPRs, Código Orgánico de la Economía Social de los Conocimientos, Creatividad e Innovación (COES) that, among other things, does not allow to patent traditional knowledge nor genes and genetic material in general. ${ }^{98}$ However, these changes arose some concerns about their negative impact on fostering innovation. ${ }^{99}$

\section{Conclusion}

The evolution of patent legislation formally begins in the fifteenth century with the Venice Statute that arises in the context of commercial economic boom. Among its objectives was commercial independence from other regions in order to strengthen the local economy, integrating and developing skills

96 To Review Changes in Greater Detail, see Falconi Puig \& Abogados Régimen común sobre propiedad industrial. Análisis comparativo entre las decisiones 344 y 486 de la Comunidad Andina de Naciones. Ius Dictio. (vol2, núm. 4, 2000), https://doi.org/10.18272/iu.v2i4.554.

Biological Diversity Act, July 10, 2002.

97 De la Cruz I., Rodrigo Regional Study in the Andean Countries: "Customary Law in the protection of traditional knowledge" (November, 2006) https://wwrw.wipo.int/export/sites/wrww/tk/en/resources/ pdf/study_cruz.pdf.

98 Código Orgánico de la Economía Social de los Conocimientos, Creatividad e Innovación [Organic Code of Social Economy of Knowledge, Creativity and Innovation], as amended, Registro Oficial Órgano del Gobierno del Ecuador, 9 de diciembre de 2016 (Quito).

99 Sophia Espinosa Colona, Código Ingenios y el sistema de patentes: ¿una propuesta innovadora o la receta hacia un estancamiento tecnológico? IURIs Dictio, Vol. 15, No. 17 (2016), https://doi.org/10.18 272/iu.v15i17.737. 
and knowledge. This ordinance regulated internal inventions and inventions brought from abroad, in addition to locally originated literary works. It is also here that was established the name of patents to the privilege granted, since the so-called privilege was inscribed in the patent letter. It is not until the seventeenth century that the letters patent is granted only to local inventions and those brought from abroad. Furthermore, the inventor is given special recognition as the only one qualified to make the monopoly valid. The United States, having been part of England as a colony, assumes these ideas at the time of independence. Similarly, a few years later France opted for the same alternative.

By the 19th century, commercial conditions, international relations and the insistence of certain nations to expand territorially the validity of patents generated the conditions to establish an Agreement in Paris for the extension of rights to industrial property, as well as penalties for unfair competition. As a consequence, the promotion begins for countries to issue or modify their national patent laws so that they are consistent with the clauses established in the Conventions. Years later they agreed on a single simplified application to apply for a patent in different countries, within the framework of the Patent Cooperation Treaty.

The Second World War changed the economic course of several regions and countries, for example the United States. With the idea of helping lessfavored nations to get rid of the lag, several Trade Agreements of the multilateral type agreed on several countries in the 20th century. An agreement related to Intellectual Property and commercial activities was the TRIPS Agreement, which is the platform for future Trade Agreements. Before the TRIPS, the commercial activity was closed to certain items, after which the pharmaceutical industry was included, and the period of granting patents for product and process inventions was extended, regardless of the place of origin or the technological field, as long as the novelty and industrial application are fulfilled.

This account has always had the monopoly at the center of the discussion: who is considered as inventor; who is the owner; who has the right to monopoly. It also takes into consideration the duration, in what areas, with what requirements, what mechanisms for revocation or prevention of abuse (compulsory license and compulsory work), the publication of the invention for the public domain and the territorial extension of the monopoly.

The international trend is an increase in the degree of legal sophistication in the use and exercise of monopoly; monopoly benefits have been expanded and mechanisms to prevent abuse have been restricted. Intellectual property has even been equated as a form of investment and this implies that monopoly exclusivity mechanisms are extended. The resolution of disputes is favored not only in intellectual property but also in investment matters in favor of particular over social interests. 


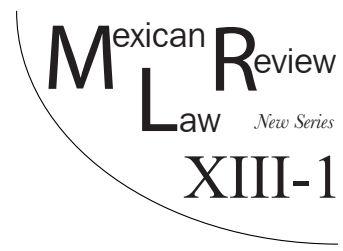

\title{
HOW DARE YOU! A GOMPARATIVE ANALYSIS OF GONSTITUTIONAL COURT DEGISIONS REGARDING INSULT LAWS IN MEXICO AND SOUTH KOREA
}

\author{
Yoomin WoN*
}

\begin{abstract}
Expressions that criticize the head of state, governmental institutions, or public officials are frequently sanctioned by criminal punishment for their use of derogatory and disrespectful language, referred to in the law as "insults". This article analyzes four judicial review decisions from the Supreme Court of Mexico and the Constitutional Court of Korea regarding insult laws from the perspective of both international human rights law and constitutional law. I argue that criminally punishing insulting expressions directed against public officials, symbols, or entities, violates the principle of freedom of expression. First, the "dignity of the nation" is not a legitimate interest warranting the restriction of insulting expressions directed at national flags or the Republic. Second, public officials should be required to tolerate a greater degree of insult than private individuals. Protection of a public function, or the honor of a public official, does not justify criminal punishment of insulting expressions. Third, the term "insult" itself is too vague, thus, its use breaches the principle of legality clarity. It also substantively restricts freedom of expression by prohibiting a wide range of utterances and activities. Based on this analysis, I argue that criminal punishment for expressions directed against national flags, public officials, and the nation, should be removed from the criminal codes. Neither the courts nor governmental authorities should criminally punish insulting expressions directed against public officials. Eliminating insult laws would not harm, but rather strengthen, democratic society in both Mexico and South Korea.
\end{abstract}

* Assistant Professor, Seoul National University School of Law,yoomin@snu.ac.kr.

This article was funded by the 2020 Research Fund of the Seoul National University AsiaPacific Law Institute, donated by the Seoul National University Law Foundation.

I would like to express my special gratitude to all the Mexican lawyers who helped me understand the Mexican legal system. This article resulted from my internship in the summer of 2016 at the Mexican Supreme Court. I thank Ministro José Ramón Cossío Díaz and the lawyers on his team for their warm welcome and hospitality. I also thank my dear friends Diana Esther Guzmán, Rolando Garcia Miron, and Franz Erwin Oberarzbacher Dávila who encouraged me and kindly helped me with this article. 
Keywords: Insult law, Supreme Court of Mexico, Constitutional Court of Korea, international human rights law.

RESUMEN: Las expresiones que critican al jefe de Estado, instituciones gubernamentales o funcionarios públicos suelen estar restringidas por normas penales que castigan los insultos y ultrajes en contra de quienes representan al Estado. Este artículo analiza cuatro sentencias judiciales de la Suprema Corte de Justicia de la Nación (México) y la Corte Constitucional de Corea sobre las denominadas leyes contra insultos ("insult laws") tanto desde la perspectiva del derecho internacional de los derechos humanos como del derecho constitucional. Sostengo que castigar penalmente los insultos contra funcionarios, simbolos o entidades públicos viola la libertad de expresión. Primero, la dignidad de la nación no es un interés legítimo para restringir las expresiones ofensivas contra las banderas nacionales o la República. Segundo, los funcionarios públicos deben tener mayor tolerancia a la crítica que los particulares. La protección de la función pública o el honor de un funcionario público no justifica el castigo penal de las expresiones verbales de insulto. Tercero, el término "insulto (ultraje)" es demasiado vago y por lo tanto viola el principio de legalidad (claridad). También viola sustancialmente la libertad de expresión al restringir una amplia gama de expresiones. Con base en este análisis, defiendo que los tipos penales que castigan las expresiones contra símbolos patrios, funcionarios públicos y la nación deben eliminarse de los códigos penales, y los funcionarios encargados de aplicarlos deben dejar de imponer castigos con base en ellos. Eliminar las leyes contra insultos fortalecería el debate democrático tanto en México como en Corea del Sur.

Palabras clave: Insulto, Suprema Corte de Justicia de la Nación (México), Corte Constitucional de Corea, derecho internacional de derechos humanos.

\section{TABle of Contents}

I. INTRODUCTION.

II. International Human Rights Law Regarding Insult Laws ...... 105

1. Universal System............................................................... 105

2. Inter-American System ...................................................... 108

III. Constitutional Protection for Freedom of Expression ......... 110

1. Political Constitution of the United Mexican States ............... 110

2. Constitution of the Republic of Korea................................ 113

IV. Decisions of the Supreme Court of Mexico Regarding

INSULT LaWs

1. Insult to the National Flag Case in 2005 (Amparo en Revisión 2676/2003, case no. 1)

2. The Insult to Authority Case in 2016 (Amparo Directo en Revisión 2255/2015, case no. 2) 
V. Decisions of the Constitutional Court of Korea on Insult LaWs

1. Insult as a Criminal Offense Case in 2013 (2012Hun-Ba37, case no. 3)

2. Insult to the Republic of Korea Case in 2015 (2013Hun-Ka20, case no. 4)

VI. Comparative Analysis of the Decisions

1. Is Protecting the Dignity of the Nation a Legitimate Purpose of Insult Laws?

2. Insult to Public Officials: More Tolerant or More Strict?.

3. Constitutional Standards: "Insult", Too Vague or Too Broad?

VII. Conclusions and Suggestions.

\section{INTRODUCTION}

The American singer, Miley Cyrus, enraged many Mexicans when a Mexican flag was used to spank false buttocks she was wearing during her concert in Monterrey, Mexico on Mexico's Independence Day, September 16, 2014. What was more problematic than the public outrage is that insulting the national flag in Mexico is illegal, and punishable by a fine of up to approximately $\$ 1,200$ and three days of jail in the state of Nuevo León where the concert took place. ${ }^{1}$ It is a criminal offense to use a Mexican flag in a disrespectful way - physically or verbally. A poet who once merely described himself using a Mexican flag as toilet paper in a poem was criminally punished. In that case, the Supreme Court of Mexico upheld the criminal punishment of the poet, declaring it to be constitutional despite the poet's argument that his freedom of expression had been violated. ${ }^{2}$

Freedom of expression is protected as a fundamental right in the constitutions of most democratic countries, ${ }^{3}$ as well as in international human rights documents. However, such freedom of expression is often restricted in order to achieve certain specifically defined purposes, such as protecting the honor or privacy of another person, or preserving public order. The varying scope of these restrictions often leads to the uncomfortable question as to whether opinions shared only by a minority of people are more legally constrained than other more popular opinions. In particular, expressions that criticize

1 Rafael Romo, Miley Cyrus' Mexican flag stunt drawes official condemnation, investigation, CNN (Sep. 22, 2014), https://werere.cnn.com/2014/09/18/showbiz/miley-cyrus-mexican-flag/index.html.

2 Primera Sala de la Suprema Corte de Justicia de la Nación [SCJN], Amparo en Revisión, $2676 / 2003$.

3 Elena Yanchukova, Criminal Defamation and Insult Laws: An Infringement on the Freedom of Expression in European and Post-Communist furisdictions, 41 Colum. J. TransnaT'L L. 861, 861 (2002). 
the head of state, governmental institutions, or public officials, are frequently subject to criminal punishment for their use of derogatory and disrespectful language, referred to in the law as "insults". 4

The constitutionality of insult laws is addressed in national constitutional courts. Four decisions of the Supreme Court of Mexico (La Suprema Corte de Fusticia de la Nación, hereinafter, "Mexican Court") and the Constitutional Court of Korea (hereinafter, "Korean Court") have considered various aspects of several different insult laws. In the first Mexican decision to be examined here, a law prohibiting insults directed at the national flag was declared constitutional by the First Chamber of the Supreme Court of Mexico in 2005. ${ }^{5}$ In the second Mexican decision, from 2016, the court declared unconstitutional a criminal provision prohibiting "insult to authority (ultraje a la autoridad)". ${ }^{6}$ The first decision from the South Korean court evaluated an insult law as a general criminal offense and determined it to be constitutional in $2013 .^{7}$ The second Korean decision, from 2015, held that a criminal provision against insults to the Republic violates freedom of expression. ${ }^{8}$ The Korean decisions were selected for their common component of "insult" warranting criminal punishment, which allows for a comparative analysis, and also highlights its importance in the Korean constitutional law jurisprudence.

These four decisions, when analyzed together, raise several questions about expressions that are alleged to be disrespectful to the authority or dignity of the state and its public officials. Is the dignity of the nation a sufficiently legitimate interest to justify restricting these expressions? Are there other legitimate interests sufficient to justify restrictions of such expressions against public entities, such as protecting the exercise of a public function or the honor of a public official? Is the term "insult" itself too vague or too broad to be criminalized? These decisions also raise the question as to which constitutional standard is appropriately applied in these cases, the principle of legality, or the substantive review of freedom of expression. In this article I will analyze these four decisions, bearing in mind the above questions.

4 Badala Tachilisa Balule, Insult laws: a challenge to media freedom in the SADC's fledgling democracies?, 41 Comparative and International Law Journal of Southern Africa 403, 405-406 (2009). Insult laws and criminal defamation in many countries excessively restricts the freedom of expression. See Patti McCracken, Insult Laws Insulting to Press Freedom. A Guide to Evolution of Insult Laws in 2010 (World Press Freedom Committee and Freedom House. 2012). Clooney and Webb analyze state practice on insult laws using categories of insulting rulers, insulting religion and insulting royalty. Amal Clooney \& Philippa Webb, The Right to Insult in International Law, 48 Colum. Hum. RTs. L. Rev. 1, 3-14 (2016).

5 Primera Sala de la Suprema Corte de Justicia de la Nación [SCJN], supra note 2.

6 Pleno de la Suprema Corte de Justicia de la Nación [SGJN], Amparo Directo en Revisión, 2255/2015.

7 Constitutional Court [Const. Ct.], 2012Hun-Ba37, Jun. 27, 2013 (2013 D.K.C.C. 1).

8 Constitutional Court [Const. Ct.], 2013Hun-Ka20, Oct. 21, 2015 (2015 D.K.C.C. 160). 
This article will examine specific issues related to freedom of expression with the following three limitations. First, regarding the content of an expression, the focus will be on freedom of expression directed against a public entity, which includes individual public officials, governmental institutions as well as symbols of the nation. This will exclude expressions that might harm the honor or privacy of a private person or expressions made by the media. While the third decision in this article is about an insult law that punished an insulting expression against a private person, I will explain how it was misused, in fact, to prohibit insults directed toward public officials.) This will also exclude "hate speech" designed to promote hatred on the basis of race, religion, ethnicity, national origin, etcetera. ${ }^{9}$ Second, I will restrict the analysis to insult laws that impose criminal punishment. Accordingly, insult laws that allow for civil liability will not be studied in this article. Third, I will focus only on laws that regulate "insulting" expressions. For example, the mere circulation of false facts or defamation will not be examined. This paper will examine insult laws that explicitly criminalize "insult" " ultraje" in Spanish, "모욕" in Korean) as a criminal offense. ${ }^{10}$

In this article, I will first analyze how international human rights law responds to national insult laws (Part I). I will then discuss the constitutional protection of freedom of expression in Mexico and South Korea (Part II). Next, I will examine the Mexican Court decisions in the cases regarding insult to the national flag and insult to authority (Part III). The following section will cover insult as a criminal offense and insult to the Republic, the two Korean Court cases under examination here (Part IV). In the last section, I will analyze and compare three key aspects of the insult law cases from these two countries: the dignity of the nation as a legimate governmental interest, insult to public officials, and the constitutional standards applied in the cases (Part V). Finally, I will conclude by outlining the reasons insult laws should be abolished, or in the alternative, subject to a more strict interpretation by the judiciary. My analysis focuses on Mexico and South Korea as representative of common legal practices on insult laws in many different countries. ${ }^{11}$

\section{International Human Rights Law Regarding Insult Laws}

\section{Universal System}

Freedom of expression is protected not only by domestic constitutions but also in international human rights documents. The Universal Declaration of

9 Michel Rosenfeld, Hate Speech in Constitutional Furisprudence: A Comparative Analysis, 24 CARDOzo L. Rev. 1523, 1523 (2002).

10 Clooney and Webb enumerate seven factors regarding context of an insult. Clooney \& Webb, supra note 4, at 24-37.

11 South Korea ranked no. 41 and Mexico ranked no. 144 out of 180 countries in the World Press Freedom Index 2019. Reporters Without Borders, 2019 World Press Freedom Index, available at https://rsf.org/en/ranking?\#. 
Human Rights, adopted in 1948, protects freedom of opinion and expression in Article 19. "Article 19 Everyone has the right to freedom of opinion and expression; this right includes freedom to hold opinions without interference and to seek, receive and impart information and ideas through any media and regardless of frontiers".

Freedom of expression is also protected by the International Covenant on Civil and Political Rights, adopted in 1966, which both Mexico and South Korea ratified in 1975 and 1990, respectively. ${ }^{12}$

Article 19

1. Everyone shall have the right to hold opinions without interference.

2. Everyone shall have the right to freedom of expression; this right shall include freedom to seek, receive and impart information and ideas of all kinds, regardless of frontiers, either orally, in writing or in print, in the form of art, or through any other media of his choice.

3. The exercise of the rights provided for in paragraph 2 of this article carries with it special duties and responsibilities. It may therefore be subject to certain restrictions, but these shall only be such as are provided by law and are necessary:

(a) For respect of the rights or reputations of others;

(b) For the protection of national security or of public order (ordre public), or of public health or morals. ${ }^{13}$

The Human Rights Committee, a treaty-body that interprets the above Covenant and monitors its implementation, highlighted the importance of freedom of expression emphasizing that it "constitutes one of the cornerstones of a democratic society" and that "the free communication of information and ideas about public and political issues between citizens, candidates and elected representatives are essential."14 The Committee clarified its position regarding limitations on freedom of expression in its General Comment No. 34 in 2011 stating that criminalization of an opinion is not compatible with Article 19 paragraph 1 of the Covenant ${ }^{15}$ which prohibits the harassment, intimidation or stigmatization of a person, including arrest, detention, trial or imprisonment for holding opinions. ${ }^{16}$

Moreover, the Human Rights Committee provides guidelines addressing laws designed to prohibit and punish expressions that insult public figures, ${ }^{17}$

12 For the draft history of Article $19 \& 20$ of the ICCPR and Article 4 of the International Convention on the Elimination of All Forms of Racial Discrimination, see Clooney \& Webb, supra note 4 , at 15-21.

13 Clooney and Webb posit that the terms of restrictions, such as "respect for the right of others" "protection of morals" are too vague. Clooney \& Webb, supra note 4, at 44.

14 Human Rights Comm., General Comment No. 34, U.N. Doc. GCPR/G/GG/34 (Sept. 12, 2011 ), para. 13, 20.

15 Clooney \& Webb, supra note 4, at 25-26, 28.

16 Human Rights Comm., supra note 14, para. 9.

17 Balule, supra note 4, 413-414. 
which is the focus of this article. All public figures are subject to criticism and political opposition. The mere fact that an expression insults a public figure does not justify imposition of criminal penalties. In this regard, the Committee expressed its concern about laws of "lese majesty, desacato, disrespect for authority, disrespect for flags and symbols, defamation of the head of state, and the protection of the honor of public officials". ${ }^{18}$

The Special Rapporteur on the promotion and protection of the right to freedom of opinion and expression, appointed by the UN Human Rights Council, addresses those types of laws. Concerning the countries of interest to the present discussion, Frank La Rue, the Special Rapporteur at that time, undertook an official mission to the Republic of Korea from May 6 through May 17 of 2010. He also visited Mexico with the Special Rapporteur for Freedom of Expression of the Inter-American Commission on Human Rights, Catalina Botero, from August 9 through August 24 of 2010. In his report on the South Korea mission, he recommended abolishing the criminal offense provisions of both defamation and insult, declaring they are "inherently harsh and have a disproportionate chilling effect on the right to freedom of expression." 19 He stressed that "public officials and bodies should refrain from filing defamation suits, since a public office entails public scrutiny as part of checks and balances in a democratic society". ${ }^{20}$ With respect to insult laws in Mexico, he acknowledged that the Mexican federal government and other federal states had decriminalized the crimes of libel, defamation, and slander, ${ }^{21}$ although other criminal punishments on the exercise of freedom of expression still remained. ${ }^{22}$ This was also reaffirmed in the Joint Report of the United Nations Special Rapporteur on the promotion and protection of the right to freedom of opinion and expression, David Kaye,

18 Human Rights Comm., supra note 14, para. 38.

19 Human Rights Council, Report of the Special Rapporteur on the promotion and protection of the right to freedom of opinion and expression, Frank La Rue, UN Doc. A/ HRC/17/27/Add.2, (Mar. 21, 2011), para. 27-28.

20 Human Rights Council, supra note 19, para.89. Park posits that international human rights standards about insult laws could be considered as interpretative tool in Korean courts. Kyung Sin Park, Special Feature: Current Issues in Constitutional Law; Freedom of Expression under International Law and Its Implications for Korean legal reform, 13 The LaW REASEARCH INSTITUTUTE OF HongIK UnIV. 87, 90-94 (2012) (in Korean).

21 Human Rights Council, Report of the Special Rapporteur on the promotion and protection of the right to freedom of opinion and expression, Frank La Rue, UN Doc. A/ HRC/17/27/Add.3, (May 19, 2011), para. 49. Article 350 to Article 355 of the Federal Criminal Code (of Mexico), which criminalized defamation and libel, were abolished on 13 April 2007.

22 Human Rights Council, supra note 21, para. 81. See Alma de los Ángeles Ríos Ruiz, El derecho de libertad de expresión en México a la luz del derecho comparado, 5 Revista In Jure Anáhuac МАYАв 84, 93-94 (2016). 
and the Special Rapporteur for Freedom of Expression of the IACHR, Edison Lanza, in their mission to Mexico in 2017.23

\section{Inter-American System}

I will now turn to the protection of freedom of expression as part of a regional human rights system, focusing only on the Inter-American System of Human Rights. Mexico has been a member state of the OAS (Organization of American States) since 1948, and the Inter-American Convention on Human Rights since 1981. As for Korea, there is no regional human rights system. Freedom of thought and expression is protected under Article 13 of the Inter-American Convention on Human Rights.

Article 13. Freedom of Thought and Expression

1. Everyone has the right to freedom of thought and expression. This right includes freedom to seek, receive, and impart information and ideas of all kinds, regardless of frontiers, either orally, in writing, in print, in the form of art, or through any other medium of one's choice.

2. The exercise of the right provided for in the foregoing paragraph shall not be subject to prior censorship but shall be subject to subsequent imposition of liability, which shall be expressly established by law to the extent necessary to ensure:

a. respect for the rights or reputations of others; or

b. the protection of national security, public order, or public health or morals.

3. The right of expression may not be restricted by indirect methods or means, such as the abuse of government or private controls over newsprint, radio broadcasting frequencies, or equipment used in the dissemination of information, or by any other means tending to impede the communication and circulation of ideas and opinions.

The Inter-American Court of Human Rights, in an advisory opinion, interpreted freedom of expression to be a cornerstone of democratic society and an indispensable element in the formation of public opinion. It added that it is "the means that enable the community, when exercising its options, to be sufficiently informed". ${ }^{24}$

23 Joint Report of the Special Rapporteur for Freedom of Expression of IACHR, Edison Lanza, and the United Nations Special Rapporteur on the promotion and protection of the right to freedom of opinion and expression, David Kaye, on their mission to Mexico, (Jun. 2018), para. 17, http://werere.oas.org/en/iachr/expression/docs/2018_06_18_CIDH-UN_FINAL_M X_report_ENG.pdf.

24 Compulsory Membership in an Association Prescribed by Law for the Practice of Journalism (Arts. 13 and 29 American Convention on Human Rights), Advisory Opinion OG5/85, Inter-Am. Ct. H.R. (ser. A), N. 5, para. 70. (of Nov. 13, 1985). 
With respect to insult laws specifically, expressions against public officials were first studied by the Inter-American Commission on Human Rights in its Annual Report in 1994. ${ }^{25}$ The Inter-American Commission included a chapter entitled "Report on the Compatibility of Desacato Laws with the American Convention on Human Rights". In this report, desacato laws are defined as "a class of legislation that criminalizes expression which offends, insults, or threatens a public functionary in the performance of his or her official duties". After a thorough study of this issue, the Inter-American Commission concluded that desacato laws are incompatible with Article 13 of the American Convention on Human Rights. Specifically, it announced that desacato laws are not legitimate restrictions of freedom of expression, nor are they necessary to ensure public order in a democratic society. ${ }^{26}$

This standard was reflected in subsequent documents, such as the Declaration of Principles on Freedom of Expression adopted by the Inter-American Commission on Human Rights in 2000. ${ }^{27}$ The Special Rapporteur on Freedom of Expression continued reporting about desacato laws in 1998, 2000, 2002, and 2004.28 Furthermore, the OAS Special Rapporteur adopted joint declarations with the UN Special Rapporteur on Freedom of Opinion and Expression, as well as the OSCE Representative on Freedom of the Media in 2000, declaring that defamation laws should reflect the importance of open debate about public concerns. ${ }^{29}$ In 2002, they reiterated that criminal defamation is not a justifiable restriction on freedom of expression and that all criminal defamation laws should be abolished and replaced with appropriate civil defamation laws. ${ }^{30}$ In 2010, the Tenth Anniversary Joint Declaration was adopted by the above Special Rapporteurs who identified ten key

25 Balule, supra note 4, at 412-413.

26 Inter-Am. Comm'n H.R., Annual Report of the Inter-American Commission on Human Rights 1994, http://cidh.oas.org/annualrep/94eng/chap.5.htm.

In 1994, the Inter-American Press Association held a conference on freedom of press at Chapultepec Castle in Mexico City, producing the Declaration of Chapultepec signed by the Heads of State of 21 of the regions. The Principle 10 states that "no news medium nor journalist may be punished for publishing the truth or criticizing or denouncing the government". Annual Report of the Office of the Special Rapporteur for Freedom of Expression of 2000, OEA/Ser./L/V/II.111. Doc. 20 rev. (Apr. 16, 2001), at 54, http://wrwre.oas.org/en/iachr/expression/docs/reports/annual/2000.pdf?DocumentID $=13$.

27 Declaration of Principles on Freedom of Expression, Principle 10 and Principle 11, http://wwre.oas.org/en/iachr/expression/showarticle.asp? artID =26 EIID $=1$.

28 Annual Report of the Office of the Special Rapporteur for Freedom of Expression of 1998, 2000, 2002, and 2004.

29 International Mechanisms for Promoting Freedom of Expression Joint Declaration 2000, http://www.oas.org/en/iachr/expression/showarticle.asp?artID=142 \&IID=1.

30 International Mechanisms for Promoting Freedom of Expression Joint Declaration 2002, http://wwre.oas.org/en/iachr/expression/showarticle.asp?artID=87 \&IID=1. 
challenges to freedom of expression for the following decade, declaring that criminal defamation represents an ongoing threat to freedom of expression. ${ }^{31}$

The Inter-American Court of Human Rights has also ruled on criminal defamation law cases. ${ }^{32}$ Since 2004, that Court has held that the right to freedom of expression was violated in prosecutions for criminal defamation against public officials or candidates and for contempt of authority (desacato) in Costa Rica, Paraguay, Chile, Argentina, and Venezuela. ${ }^{33}$

\section{Constitutional Protection for Freedom of Expression}

\section{Political Constitution of the United Mexican States}

Before analyzing the specific court decisions, it is necessary to examine how freedom of expression is protected by the constitutions of the two countries. First, in Mexico, Articles 6 and 7 of the Political Constitution of the United Mexican States guarantee freedom of expression as follows: ${ }^{34}$

Article 6. Expression of ideas shall not be subject to judicial or administrative inquiry, except for those cases when such expression of ideas goes against the moral, privacy or the rights of third parties, causes perpetration of a felony, or

31 Tenth Anniversary Joint Declaration: Ten Key Challenges to Freedom of Expression in the Next Decade 2010, http://www.oas.org/en/iachr/expression/showarticle.asp? artID=784 \&IID=1.

Insult law cases are also discussed in Europe. The European Court of Human Rights decided in 2013 that the French President should not be over-protected from satirical insult. Eon v. France, App. No. 26118/10, Eur. Ct. H.R., (Mar. 14, 2013). Before the 2013 decision, the European Court of Human Rights also decided in 2002 that punishing the publishing director and journalist of a French newspaper, Le Monde, for defamation of the King of Morocco violated freedom of expression by France. Colombani (Le Monde) v. France, App. No. 51279/99, (Jun 25, 2002).

32 Richard N Winfield \& Kristin Mendoza, The Abolition Movement: Decriminalizing Defamation and Insult Laws, 25 Comm. Law. 7, 8-9 (2007).

33 Herrera Ulloa v. Costa Rica, 2004 Inter-Am. Ct. H.R. (ser. C) No. 107 (Jul. 2, 2004); Canese v. Paraguay, 2004 Inter-Am. Ct. H.R. (ser. G) No. 111 (Aug. 31, 2004); Palamara Iribarne v. Chile, 2005 Inter-Am. Ct. H.R. (ser. G) No. 135, (Nov. 22, 2005); Kimel v. Argentina, 2008 Inter-Am. Ct. HR (Ser. G) No. 177 (May 2, 2008); Tristán Donoso Vs. Panamá, 2009 Inter-Am. Ct. HR (Ser. C) No. 193; Usón-Ramírez v. Venezuela, 2009 Inter-Am. Ct. HR (Ser. C) No. 207. Winfield and Mendoza also introduce recent decisions from the European Court of Human Rights on this issue. Winfield \& Mendoza, supra note 33, at 7-8.

The Declaration of Principles on Freedom of Expression in Africa recognizes that insult laws are subject to abuse. Balule, supra note 4, at 411.

34 For the meaning of the articles 6 and 7, see Francisca Pou Giménez, La libertad de expresión y sus limites, Derechos humanos en la Constitución. Jurisprudencia nacional e interamericana 901, 901-912 (2013). 
disturbs the public order. The right of reply shall be exercised according to law. The State shall guarantee the right to information. ${ }^{35}$

Article 7. Freedom of speech, opinion, ideas and information through any means shall not be abridged. Said right shall neither be abridged through any indirect means, such as abuse of official or private control over paper, radio electric frequencies or any other materials or devices used to deliver information, or through any other means or information and communication technologies aimed at impeding transmission or circulation of ideas and opinions.

No statute or authority shall establish prior restraints, nor shall it abridge freedom of speech, which shall be subject to no other limitation than those foreseen in the first paragraph of Article 6 of this Constitution. Under no circumstances shall the assets used for the transmission of information, opinions and ideas be subject to seizure on the grounds of being an instrumentality of a felony. ${ }^{36}$

The Supreme Court of Mexico has emphasized the importance of freedom of expression in a democracy as a means of communication. ${ }^{37}$ The Mexican Court stresses both the individual and public aspect of freedom of expression. On the one hand, the individual dimension of freedom of expression requires a high level of protection to ensure the fundamental value of individual autonomy. As a result, freedom of expression has been recognized as an indispensable condition for other forms of freedom. ${ }^{38}$ On the other hand, the political dimension of freedom of expression is a centerpiece of representative democracy. It emphasizes the importance of the free flow of ideas and opinions in debates on public issues. In this respect, freedom of expression is linked to political pluralism and the fundamental values of democratic states. ${ }^{39}$ It allows for a truly representative government in which citizens participate effectively in decisions involving the public interest. ${ }^{40}$

35 Article 6 of the Mexican Constitution establishes state's obligation not to interfere with the exercise of the freedom of expression and the limits for the exercise of this freedom. Ríos Ruiz, supra note 22, at 87.

36 Translation by María Fernanda Gómez Abán, available at https://archivos.juridicas.unam. $m x /$ werw/legislacion/federal/leyes/consting.pdf.

37 See also Libertad de Expresión. Dimensiones de su Contenido, Pleno de la Suprema Corte de Justicia de la Nación [SCJN], Semanario Judicial de la Federación y su Gaceta, Novena Época, tomo XXV, Mayo de 2007, Tesis P./J. 25/2007, Página 1520; José RamóN Cossío Díaz et al., La Libertad de Expresión en las Sentencias de la Suprema Corte de Justicia (2014), at 9.

38 Libertad de Expresión. Dimensión Individual de Este Derecho Fundamental, Primera Sala de la Suprema Corte de Justicia de la Nación [SCJN], Gaceta del Semanario Judicial de la Federación, Décima Época, Libro 13 Tomo I, Diciembre de 2014, Tesis Aislada, la. CDXX/2014 (10a.), Página 233.

39 Juan Antonio Cruz Parcero, De poemas, banderas, delitos y malas decisiones. La sentencia de la Suprema Corte sobre el caso Witz, 56 Revista de la Facultad de Derecho de MéXico 423, 432 (2006).

40 Libertad de Expresión. Dimensión Política de Este Derecho Fundamental, Primera 
Regarding expressions directed at public officials and public figures, the Mexican Court adopted "the dual protection system (sistema dual de protección)" from the 2008 Report of the Special Rapporteur for Freedom of Expression of the Inter-American Commission on Human Rights in its decision of Amparo Directo en Revisión 2044/2008. ${ }^{41}$ Expressions directed at public officials and public figures enjoy a higher degree of protection, and such persons should have a higher threshold of tolerance for criticism. ${ }^{42}$ As criticism is essential in a democratic system, the permissible limits are more broad when critics are referring to people who engage in public activities. ${ }^{43}$ The threshold for criminal or civil responsibility for expressions against public officials is higher than for expressions against private individuals. ${ }^{44}$

However, not all of these types of expressions are protected by the Mexican Constitution. The SJCN specifically announced that the Mexican Constitution does not recognize the right to insult. Although the Constitution does not prohibit expressions that are unusual, alternative, indecent, outrageous or contrary to majority beliefs, insults are not protected by the Constitution. As a result, the right to honor prevails in cases regarding the expression of insults. However, the Mexican Court has also held that the political or social

Sala de la Suprema Corte de Justicia de la Nación [SCJN], Gaceta del Semanario Judicial de la Federación, Décima Época, Libro 13 Tomo I, Diciembre de 2014, Tesis Aislada, la. CDXIX/2014 (10a.), Página 234.

41 Primera Sala de la Suprema Corte de Justicia de la Nación [SGJN], Amparo Directo en Revisión, 2044/2008.

42 Libertad de Expresión y Derecho a la Información. Concepto de interés público de LAS EXPRESIONES, INFORMACIONES, IDEAS Y OPINIONES SOBRE FUNCIONARIOS Y CANDIDATOS, Primera Sala de la Suprema Corte de Justicia de la Nación [SCJN], Gaceta del Semanario Judicial de la Federación, Décima Época, Libro 5 Tomo I, Abril de 2014, Tesis Aislada, 1a. CLII/2014 (10a.), Página 806; Cossío Díaz et al., supra note 38, at 11.

43 Libertad de Expresión y Derecho a la Información. Su protección es especialmente intensa en materia Política y asuntos de interés público, Primera Sala de la Suprema Corte de Justicia de la Nación [SCJN], Semanario Judicial de la Federación y su Gaceta, Novena Época, Tomo XXX, Diciembre de 2009, Tesis Aislada, la. CCXVII/2009, Página 287.

44 Libertad de Expresión y Derecho a la Información. La RESPONSABILIDAD POR INVASIONES AL HONOR DE FUNCIONARIOS U OTRAS PERSONAS CON RESPONSABILIDADES PÚBLICAS SÓLO PUEDE DARSE Bajo CiERTAS CONDiCiONES, MÁs ESTRICTAS QUE LAS QUE SE APLICAN EN EL CASO DE EXPRESiOnes o informaciones referidas a ciudadanos Particulares, Primera Sala de la Suprema Corte de Justicia de la Nación [SCJN], Semanario Judicial de la Federación y su Gaceta, Novena Época, Tomo XXX, Diciembre de 2009, Tesis Aislada, la. CCXXI/2009, Página 283.

One of the main consequences of dual protection system is the "actual malice", which imposes civil penalties only in cases where false information (in case of the right to information) or has been produced with "actual malice" (applicable to both the right to information as to freedom of expression). LiberTAD DE Expresión. Sus límites a LA LUZ DEL SISTEMA DE PROTECCión DUAL y Del estándar de malicia efectiva, Primera Sala de la Suprema Corte de Justicia de la Nación [SCJN], Semanario Judicial de la Federación y su Gaceta, Décima Época, Libro XIX Tomo 1, Abril de 2013, Tesis Jurisprudencial, 1a./J. 38/2013 (10a.), Página 538. 
situation of a State, and circumstances of the expression itself, may mitigate the offense and permit an increased degree of tolerance. ${ }^{45}$

As noted above, the Mexican federal government and other federal states did decriminalize the crimes of libel, defamation, and slander, ${ }^{46}$ although other laws that allow criminal punishment for the exercise of freedom of expression still remain. ${ }^{47}$

\section{Constitution of the Republic of Korea}

The Constitution in South Korea protects freedom of expression in Article 21, which provides as follows:

Article 21

(1) All citizens shall enjoy freedom of speech and the press, and freedom of assembly and association.

(2) Licensing or censorship of speech and the press, and licensing of assembly and association shall not be permitted.

(3) The standards of news service and broadcast facilities and matters necessary to ensure the functions of newspapers shall be determined by Act.

(4) Neither speech nor the press shall violate the honor or rights of other persons nor undermine public morals or social ethics. Should speech or the press violate the honor or rights of other persons, claims may be made for the damage resulting therefrom. ${ }^{48}$

Article 21 protects both freedom of speech and freedom of the press, that is, freedom of expression. Since shortly after its inauguration in 1988, the Constitutional Court of Korea ("Korean Court") has emphasized the importance of freedom of expression, holding it to be one of the most important fundamental rights in a democratic nation and essential to individual human dignity and the pursuit of happiness. ${ }^{49}$ The Korean Court has also underscored the dual constitutional aspect of freedom of expression: it is necessary not only for individual self-fulfillment, but for democracy itself.

The Korean Court has held that in a free and democratic system, where ruler and ruled are one, the public needs to know about the decisions and actions of political leaders. Freedom of expression is not only a means of

45 Libertad de Expresión. La Constitución no Reconoce el derecho al insulto. Primera Sala de la Suprema Corte de Justicia de la Nación [SCJN], Semanario Judicial de la Federación y su Gaceta, Décima Época, Libro XIX Tomo 1, Abril de 2013, Tesis Jurisprudencia, 1a./J. 31 /2013 (10a.), Página 537.

46 Human Rights Council, supra note 21, para. 49. McCracken, supra note 4, at 100-101.

47 Human Rights Council, supra note 21, para. 81. Ríos Ruiz, supra note 22, at 93.

48 Translation from the website of the Constitutional Court of Korea, wrwre.ccourt.go.kr.

49 Constitutional Court [Const. Ct.], 89Hun-Ka104, Feb. 25, 1992 (4 K.C.C.R. 64). 
promoting individual self-fulfillment and the pursuit of truth, it also allows individuals to participate in the development of political and social policy. Democratic societies do not subscribe to the belief in the infallibility of the government. The government, as well as individuals in governmental positions, may commit errors. Considering the historical evidence of errors committed by those in positions of power, a truly democratic system should promote the idea that government can minimize errors by subjecting itself to public criticism. Typically, freedom of expression has a superior constitutional claim to all other fundamental rights because it forms the basis on which a self-governing system functions, allowing the ruled to actively participate in the system by criticizing the those holding positions of political authority. ${ }^{50}$

The Korean Court applies a different standard when reviewing freedom of expression when it concerns public figures or the public interest. It has held that:

depending on the whether the victim of the defamatory statement is a public or a private figure and whether the statement is a matter of public concern or a matter in a purely private area, there should be a difference in the constitutional standard of review. Restrictions on defamatory statements against public figures concerning their public activities should be relatively more relaxed than those against private figures.

Even matters concerning a public official's personal life may fall within the scope of public concern in some cases. Nevertheless, the Korean Court does limit freedom of expression when it is directed against a public figure or involves a public concern. The Court has held that "An attack against an individual that is malicious or substantially lacks reasonableness, both based on a clearly false statement exceeding the acceptable level of exaggeration in the ordinary sense, may be subject to restriction". ${ }^{51}$

\section{Decisions of the Supreme Court of Mexico Regarding Insult Laws}

The first Mexican decision under examination here was rendered by the First Chamber of the Mexican Court on October 5, 2005 (Amparo en Revision 2676/2003). In that case, the Mexican Court upheld the constitutionality of Article 191 of the Federal Penal Code, which allows for imprisonment from six months to four years and/or a fine of 50 to 3,000 pesos for anyone who insults the coat of arms of the Republic or the national flag, either in word

\footnotetext{
50 Constitutional Court [Const. Ct.], 89Hun-Ka104, Feb. 25, 1992 (4 K.C.C.R. 64), at 94-95.

51 Constitutional Court [Const. Ct.], 2009Hun-Ma747, Dec. 26, 2013 (2013 D.K.C.C. 205), at 207-208.
} 
or action. The second Mexican decision to be examined here was reached by the Full Chamber of the Mexican Court on March 7, 2016 (Amparo Directo en Revisión 2255/2015). In that case, the Mexican Court declared Article 287 of the Penal Code for the Federal District to be unconstitutional in this particular case when applied to a crime committed against a public servant while in the performance of his or her lawful functions.

\section{Insult to the National Flag Case in 2005 (Amparo en Revision 2676/2003, case no. 1$)^{52}$}

We will begin with the insult to the national flag case, known as the "damned poet case" (caso del poeta maldito), or "the Sergio Witz case". ${ }^{53}$ Sergio Witz, a poet and university literature professor, published a poem entitled "Invitación (La patria entre mierda)". which means "Invitation (The Country Among Shit)", in a magazine called "Criterios" in April 2001. ${ }^{54}$ The problematic expression was contained in a section of the poem where the poet imagines himself using the Mexican flag as toilet paper. ${ }^{55} \mathrm{He}$ was charged under Article 191 of the Federal Penal Code, which allows for the imposition of either a fine, or up to 4 years of imprisonment, for anyone found guilty of insulting national symbols, including the national flag. ${ }^{56}$ This case reached the First Chamber (La Primera Sala) of the Mexican Court which addressed the constitutionality of the above provision. On October 5, 2005, a three justice majority opinion found against the poet, while two other justices dissented based on their belief that the poet was entitled to freedom of expression in this instance. ${ }^{57}$ As for his sentence, on May 7, 2008, a federal court found him guilty and ordered him to pay a fine of 50 Mexican pesos (approximately $2.28 \mathrm{US}$ dollars). ${ }^{58} \mathrm{Ar}-$

52 Primera Sala de la Suprema Corte de Justicia de la Nación [SCJN], supra note 2.

53 See Cossío DíAz et al., supra note 38, at 19-24.

54 Pou Gimenez explains that this case was an easy case because it was about the verbal insult rather than physical, content rather than format of the poem, with a message of political dimension, not targeting any specific individual. Pou Giménez, supra note 35, at 924; Francisca Pou, El precio de disentir. El debate interno en la Corte, Isonomía. Revista de TeOría y Filosofía deL Derecho 187, 187-188 (2006).

55 The opening lines of the poem are as following: "I / clean my urine / on the flag / of my country / That rag / that dogs lie on / and that represents nothing". Translation from http://wwrw.banderasnews.com/0805/edat-poetfined.htm.

56 Pou Giménez, supra note 35, at 922-925. For comparable cases of burning national flags and other symbols in the United States of America, see Smith v. Goguen, 415 U.S. 566 (1974); Johnson v Texas, 491 U.S. 397 (1989); U. S. v. Eichman, 496 U.S. 310 (1990); U. S. v. O’Brien, 391 US 367 (1968); R. V. A. v. City of St. Paul, 505 US 377 (1992).

57 Octavio Díaz Alderet, Conjeturas acerca de la limitación a la libertad de expresión, por respeto a los símbolos patrios (caso del poeta maldito), Cuestiones Constitucionales 369, 370 (2007).

58 Carlos Avilés Allende, Multan a poeta que escribió versos contra la bandera, El Universal (May. 
ticle 191 of the Federal Penal Code states: ${ }^{59}$ "Article 191 of the Federal Penal Code. ${ }^{60}$ One who insults the coat of arms of the Republic or the national flag, in word or action, shall be imprisoned from six months to four years and/or fined 50 to 3,000 pesos." 61

The majority opinion, written by Justice José de Jesús Gudiño Pelayo, found Article 191 of the Federal Penal Code to be constitutional and did not breach the freedom of expression described in Articles 6 and 7 of the Mexican Constitution. ${ }^{62}$ The majority opinion held that the purpose of this provision is the dignity of the nation. ${ }^{63}$ They interpreted national symbols to be constitutionally protected based on Articles 3, 73, and 130 of the Mexican Constitution. Article 3 provides that education shall induce love for the homeland, and that insults to national symbols are therefore in opposition to that Article. ${ }^{64}$ Article 130 Paragraph 2(e) states that religious ministers may not offend any national insignia, although it does not prohibit the imposition of the same limitation on others. ${ }^{65}$ Article 73 Section XXIX-B empowers Congress to enact legislation regarding the elements and use of the national flag, coat of arms, and anthem. Referring to the legislative history, the majority opinion interpreted Article 73 as protecting national symbols from disrespectful acts at the constitutional level by criminalizing them. ${ }^{66}$ The majority opinion concluded that the protection of national symbols is recognized under the Mexican Con-

7, 2008), http://archivo.eluniversal.com.mx/notas/505032.html (Exchange rate of $1 \mathrm{USD}=22.01$ MXN on Mar. 13, 2020).

5936 OSCE states have criminal laws prohibiting insult and/or desecration of state symbols. Scott Griffen, Defamation and Insult Laws in the OSCE Region: A Comparative Study 2017, at 20-21.

60 On 13 April 2007, the Mexican federal government published a judicial reform that decriminalized the crimes of libel, defamation, and slander in the Federal Penal Code. However, Article 191 remained valid despite this reform. Ríos Ruiz, supra note 22, at 93.

61 Translation by me. The fine is equivalent to 2.27 to 136.38 US Dollars (Exchange rate of $1 \mathrm{USD}=22.01 \mathrm{MXN}$ on March 13, 2020)

62 Primera Sala de la Suprema Corte de Justicia de la Nación [SCJN], supra note 2, at 94-96.

Carbonell argues that the majority opinion should have announced that the questioned provision violates the principle of proportionality. Miguel Carbonell, Silenciar al disidente. La Suprema Corte del México contra la libertad de expresión, Isonomía 1, 13-14 (2006), http://wrere.miguelcarbonell. com/artman/uploads/1/Ultrajando_a_la_Constituci_n.pdf(on file with author).

63 Primera Sala de la Suprema Corte de Justicia de la Nación [SCJN], supra note 2, at 93-97.

64 Primera Sala de la Suprema Corte de Justicia de la Nación [SCJN], supra note 2, at 97-98.

65 Primera Sala de la Suprema Corte de Justicia de la Nación [SCJN], supra note 2, at 98-99. López Salas explains that Article 130 is the only restriction on the state symbol in the Mexican constitution. Rafaela López Salas, El caso Sergio Witz: ‘un conflicto de derechos?, CuestioNES CONSTITUCiOnALES 435, 437 (2007).

66 Primera Sala de la Suprema Corte de Justicia de la Nación [SCJN], supra note 2, at 99- 
stitution, and that fact justifies restricting freedom of expression. One may express ideas against national symbols, but may not insult them. ${ }^{67}$ In other words, the state may adopt measures to protect national symbols, including criminal punishment. ${ }^{68}$

The majority opinion also mentioned that using the word "ultraje (insult)" in Article 191 of the Federal Penal Code to describe the prohibited conduct is not vague and would not be applied arbitrarily. It declared that Article 191 does not breach the principle of legal certainty. ${ }^{69}$ The majority opinion held that there can be no doubt about what the lawmakers intended when they used the word "ultraje (insult)": it does not penalize dissenting opinions about national symbols, only insulting ones. ${ }^{70}$ The majority opinion did not reach the question as to whether the criminal punishment (a fine or up to 4 years of imprisonment) was disproportionate because a definitive sentence had not yet been declared in that case. ${ }^{71}$

The dissenting opinion, on the other hand, by Justice José Ramón Cossío Díaz and Justice Juan N. Silva Meza, concluded that freedom of expression was breached. The dissent stressed the importance of freedom of expression in a democratic society. ${ }^{72}$ In their view, when the legislature limits freedom of expression, the restriction should be necessary, proportional, and compatible with the principles, values, and constitutional rights of Mexican society. ${ }^{73}$ Regarding Article 191, the dissent first argued that Article 191 cannot be justified by any exception provided in Article 6 in the Mexican Con-

125. Article 73 XXI empowers the Congress to establish the crime and misdemeanors against the Federation and determine the penalties.

67 Primera Sala de la Suprema Corte de Justicia de la Nación [SCJN], supra note 2, at 123.

68 Primera Sala de la Suprema Corte de Justicia de la Nación [SCJN], supra note 2, at $97-125$.

69 Carbonell criticizes the majority opinion that the phrase is vague and it enables authorities to apply arbitrarily. Carbonell, supra note 63, at 12.

70 Primera Sala de la Suprema Corte de Justicia de la Nación [SCJN], supra note 2, at 125-127.

71 Primera Sala de la Suprema Corte de Justicia de la Nación [SCJN], supra note 2, at 127. Morales Sánchez and Carbonell criticized that the Mexican Court did not consider international human rights treaties signed by Mexico. Julieta Morales Sánchez, El Case Witz Rodríguez a la Luz del Derecho Internacional de los Derechos Humanos: Ponderación Constitucional, Libertad de Expresión y Limites, 9 Revista do Instituto Brasileiro de Direitos Humanos 127, 129 (2009); Carbonell, supra note 63, at 5-7.

72 Primera Sala de la Suprema Corte de Justicia de la Nación [SCJN], supra note 2, Voto de Minoría, at 1-6. Gama Leyva explains that the free circulation of ideas is important in a democratic society, as in the marketplace of ideas. Leopoldo Gama Leyva, La criminalización de la conciencia disidente (Caso del Poeta Maldito), 1, 2-3, https://wrere.academia.edu/20084996/La criminalizaci\%C3\%B3n_de_la_conciencia_disidente_Caso_del_Poeta_Maldito_.

73 Primera Sala de la Suprema Corte de Justicia de la Nación [SCJN], supra note 2, Voto de Minoría, at 6. 
stitution, that is, attacking the morals or rights of others, provoking crime, or disturbing the public order. ${ }^{74}$ Thus, they did not agree with the majority opinion that Articles 3, 73, and 130 of the Mexican Constitution protect the national flag and coat of arms. ${ }^{75}$ The dissent declared that it is incompatible with the Mexican Constitution that national symbols are protected by the criminal punishment of individuals since this requires the sacrifice of fundamental individual rights. ${ }^{76}$ The two justices also highlighted the severity of the potential punishment, specifically, the fact that the author of the poem could have been punished with up to 4 years in prison demonstrated that the legislature did not properly balance the constitutional limits to freedom of expression. ${ }^{77}$ Furthermore, they regarded the concept of "ultraje (insult)" to be vague, and combined with the disproportionate punishment, had a particularly negative and chilling effect on freedom of expression. ${ }^{78}$ The dissenting opinion concluded that Article 191 of the Federal Penal Code violated freedom of expression and that this Article should not be applied in this specific case. ${ }^{79}$

\section{The Insult to Authority Case in 2016 (Amparo Directo en Revisión $2255 / 2015$, case no. 2) ${ }^{80}$}

The defendant in this case was criminally charged as a result of insulting police officers while they were performing an operation to remove street merchants in Mexico City on February 22, 2014. ${ }^{81}$ The criminal proceeding was

74 Primera Sala de la Suprema Corte de Justicia de la Nación [SCJN], supra note 2, Voto de Minoría, at 6-13.

75 Primera Sala de la Suprema Corte de Justicia de la Nación [SCJN], supra note 2, Voto de Minoría, at 13-16.

76 Primera Sala de la Suprema Corte de Justicia de la Nación [SCJN], supra note 2, Voto de Minoría, at 17.

77 Primera Sala de la Suprema Corte de Justicia de la Nación [SCJN], supra note 2, Voto de Minoría, at 17. Cruz Parcero also explains that the freedom to artistic creation also merits special protection. Cruz Parcero, supra note 40, at 434. Gama Leva posits that imposing criminal punishment on insulting certain value on state symbols violates the duty of neutrality of the state. Gama Leyva, supra note 73, at 7-8.

78 Primera Sala de la Suprema Corte de Justicia de la Nación [SCJN], supra note 2, Voto de Minoría, at 17-18.

79 Primera Sala de la Suprema Corte de Justicia de la Nación [SCJN], supra note 2, Voto de Minoría, at 19-20. Pou posits that the official opinion analyzed this article as an abstract norm while the dissenting opinion reviewed it in the light of concrete case. Pou, supra note 55, at 190191. Gama Leyva argues that article 191 of Federal Penal Code is a violation of the freedom of expression, freedom of conscience and the equality between citizens and their thoughts. Gama Leyva, supra note 73, at 9.

80 Pleno de la Suprema Corte de Justicia de la Nación [SCJN], supra note 6.

81 What she said to the police officers or the merchants in Spanish were as the following: 
initiated against her as a result of insulting a person in a position of authority under Article 287 of the Penal Code for Mexico City. She was sentenced to 10 months and 15 days of imprisonment and a fine of 2,691.60 Mexican pesos. She was granted imprisonment penalty substitution (sustitución de la pena de prisión). ${ }^{82}$ By a vote of 9 to 2, the Mexican Court held that Article 287 infringes upon Article 14 of the Mexican Constitution. That Article emphasizes the principle of legality, and when applied to the facts of this case, in the majority view, the word "ultraje (insult)" lacked certainty. Article 287 provides: "Article 287 of the Penal Code for Mexico City. Any person who insults an authority in the exercise of his/her functions, or with intent to do so, shall be imprisoned from six months to two years, and subject to a fine from 20 to 100 days of the minimum wage". ${ }^{83}$

The majority opinion, written by Justice José Fernando Franco González Salas, reviewed this provision under the principle of legality, which is enshrined in both Article 14 of the Mexican Constitution as well as Article 9 of the Inter-American Convention of Human Rights, both of which require criminal offenses be defined in a clear and precise manner. ${ }^{84}$ Among the elements that constitute the crime of insulting an authority, the behavior component of insulting (ultrajar) was carefully examined. ${ }^{85}$ The majority opinion held that the wording, even using a dictionary definition, covers a wide range of possible conduct. ${ }^{86}$ The majority opinion then interpreted that word in light of the entire provision and the context of the insulting expressions in the case. ${ }^{87}$ They concluded that even when considering the additional condition that the object of the insult must be an authority in the exercise of his functions did not sufficiently or reasonably limit the wide range of conduct that

"hijos de su pinche madre, yo me pongo porque me pongo, ustedes pinches gatos hambreados no van a impedir que mis comerciantes se instalen, no saben con quién se meten, yo conozco a los de la delegación y se van a quedar sin chamba." "ustedes pónganse, ustedes instálense, que estos pinches hambreados no nos van a impedir que nos pongamos." "pinche gato hambreado ni tú ni nadie nos va a quitar de aquí". Pleno de la Suprema Corte de Justicia de la Nación [SGJN], supra note 6, at 4.

82 Lennan introduces Coleman v. Power decision by the High Court of Australia that involves the use of insulting words against a police officer. Jo Lennan, Lawes Against Insult: History and Legitimacy in Coleman v Power, 10 Legal Hist. 239 (2006).

83 Translation by me. The number of days in fine refers daily minimum wage. In this case the fine is of 20 to 100 days of daily minimum wage.

16 OSCE states have criminal laws prohibiting defamation or insult of state institutions. One of three types is prohibiting insult to public officials in the exercise of public office. Griffen, supra note 60, at 21-22

84 Pleno de la Suprema Corte de Justicia de la Nación [SCJN], supra note 6, at 18-27.

85 Pleno de la Suprema Corte de Justicia de la Nación [SCJN], supra note 6, at 28.

86 Pleno de la Suprema Corte de Justicia de la Nación [SCJN], supra note 6, at 29-31.

87 Pleno de la Suprema Corte de Justicia de la Nación [SCJN], supra note 6, at 32-33. 
would be subject to criminal sanction by the state. ${ }^{88}$ For these reasons, the majority concluded that Article 287 violates the principle of legality. ${ }^{89}$

Jorge Mario Pardo Rebolledo's dissenting opinion argued that Article 287 does not breach the principle of legal certainty nor freedom of expression. ${ }^{90}$ The dissent claimed that the concept of "ultraje (insult)" clearly establishes the conduct to be sanctioned since it specifies serious offenses and aggression, either verbal or physical, directed at an authority in the exercise of his/ her functions. ${ }^{91}$ The opinion also made reference to the decision in the insult to the national flag case previously discussed above, Amparo en Revisión 2676/2003. ${ }^{92}$ The dissent further argued that the need to maintain public order is a legitimate objective justifying a limitation on freedom of expression. Article 287 protects public order and security by criminalizing conduct that interferes with a public service, and therefore has a legitimate purpose. ${ }^{93}$

The concurring opinion, written by Justice Alfredo Gutiérrez Ortiz Mena, agreed with the conclusion of the majority, but stressed that Article 287 also infringes upon freedom of expression. ${ }^{94}$ The broad terms of that Article do not meet agreed upon standards of human rights and unfairly restrict freedom of expression. ${ }^{95} \mathrm{He}$ concluded that the Article is unconstitutional since it is overly inclusive and therefore detrimental to freedom of expression. In his view, the Article also failed to satisfy the strict test of proportionality. ${ }^{96}$

This decision signaled a change in insult law cases in Mexico. Although the Mexican Court had previously decided criminal punishment for insulting the national flag was constitutional in 2005, it decided that criminal punishment for insulting an authority infringes upon freedom of expression just eleven years later. ${ }^{97}$ Similar issues were also being raised regarding freedom of expression on the other side of the world, in South Korea.

88 Pleno de la Suprema Corte de Justicia de la Nación [SCJN], supra note 6, at 33-34.

89 Pleno de la Suprema Corte de Justicia de la Nación [SCJN], supra note 6, at 35.

90 Pleno de la Suprema Corte de Justicia de la Nación [SCJN], supra note 6, Voto Particular, at 1 .

91 Pleno de la Suprema Corte de Justicia de la Nación [SCJN], supra note 6, Voto Particular, at 3-4.

92 Pleno de la Suprema Corte de Justicia de la Nación [SCJN], supra note 6, Voto Particular, at 4

93 Pleno de la Suprema Corte de Justicia de la Nación [SCJN], supra note 6, Voto Particular, at 7 .

94 Pleno de la Suprema Corte de Justicia de la Nación [SCJN], supra note 6, Voto Concurrente, at 1 .

95 Pleno de la Suprema Corte de Justicia de la Nación [SCJN], supra note 6, Voto Concurrente, at 1 .

96 Pleno de la Suprema Corte de Justicia de la Nación [SCJN], supra note 6, Voto Concurrente, at 1 .

97 The Mexican Court also held that terms in Article 362 of the Penal Code for Mexico City, such as "extreme violence" and "disturbance of the public peace", are not sufficiently 


\section{Decisions of the Gonstitutional Gourt of Korea on Insult Laws}

\section{Insult as a Criminal Offense Case in 2013 (2012Hun-Ba37, case no. 3)}

The first Korean decision is the case 2012Hun-Ba37 decided by the Korean Court on June 27, 2013, famously known as the "unheard-of nobody (듣보 잡, dutbojab)" case. ${ }^{98}$ This case arose out of a debate between two famous critics in South Korea, one being the progressive critic, Chin Joong-kwon, and the other, Byun Hee-Jae, a conservative critic. Chin had made online posts calling Byun an "unheard-of nobody (dutbojab)", which is a shortened form of "unheard-of and unseen nobody", a new online slang term that refers to a person or thing that is not well known. Chin was prosecuted on charges of insult for making posts insulting a person on his blog, as well as on the members' page of the New Progressive Party's website. He was also charged with defamation online. ${ }^{99}$ Chin was consequently sentenced to 3 million Korean won in fines by the trial court (approximately 2,457 US dollars) for charges of insult and other additional charges. ${ }^{100}$ Chin responded by filing a constitutional complaint to the Korean Court on January 25, 2012. The Korean Court decided by a vote of 5-3 that the insult law is constitutional and does not infringe upon any constitutional principles. The Article at issue provides as follows ${ }^{101}$ : "Article 311 (Insult) of the Criminal Act. A person who publicly insults another shall be punished by imprisonment or imprisonment without prison labor for not more than one year or by a fine not exceeding two million won". ${ }^{102}$

precise and Article 362, therefore, is not in conformity with the principle of legality. Primera Sala de la Suprema Corte de Justicia de la Nación [SCJN], Amparo Directo en Revisión, $4384 / 2013$.

98 Constitutional Court [Const. Ct.], supra note 7. This decision has a precedent over the same Article but the second decision triggered more debate in the Korean society. The first decision is case 2009Hun-Ba199 decided on 30 June 2011. Constitutional Court [Const. Ct.], 2009Hun-Ba199, Jun. 30, 2011 (23-1B K.C.C.R. 337).

99 He was also charged for defaming a person by publicly disclosing false information for purpose of libel on the New Progressive Party website.

100 Exchange rate 1 USD = 1,220.60 Korean won on March 13, 2020.

101 For an analysis on court decisions, see Sung Soo Pyo, A Study on the Problems of the Insult Crime in The Criminal Code and the Way How to Fix Them, 64 Lawyers Association Journal 5, 13-16 (2015) (in Korean).

102 Translation from website of the Legislative Translation Center, http://elaw.klri.re.kr/ kor_service/lawVieve.do?hseq $=28627$ Elang $=E N G$. The amount is equivalent to 1,638 US dollars. Exchange rate 1 USD $=1,220.60$ Korean won on March 13, 2020. Park explains that criminalization of insulting expressions involving prosecution by prosecutor's office as in South Korea is not commonly found in other countries. Park, supra note 20, at 114 (in Korean). 
The majority first announced their determination that the Article did not violate the principle of clarity, which is required under the principle of legality. 103 They defined the term "insult" to be "an abstract judgment or an expression of derogatory emotion, unaccompanied by factual statements, that can undermine one's social reputation". ${ }^{104}$ After a consideration of both the legal interests and the legislative purpose behind penalizing the crime of insult, the Court concluded that it is reasonable to expect that an ordinary citizen with common sense, and a conventional sense of the law, to foresee what kind of acts are prohibited. ${ }^{105}$ The majority also added that "there is no concern for arbitrary interpretation by law enforcement agencies". 106

The majority then held that Article 311 of the Criminal Act does not violate the freedom of expression protected by the Korean Constitution. ${ }^{107}$ Applying a balancing test, the majority assigned more weight to the right to personality and reputation than to the right of freedom of expression in a case of insulting words. ${ }^{108}$ The majority ruled that in a case where an expression insulting someone's character is made publicly, "the victim's social status will be degraded and the potential for his/her life and development as a member of society will inevitably be affected". ${ }^{109}$ As a result, according to the majority view, the act of defamation using insulting words needs to be prohibited. The majority also considered as mitigating factors the fact that insult is punishable only after a victim files a complaint and has a relatively low statutory maximum. ${ }^{110}$ The opinion also considered that courts generally seek an adequate balance between freedom of expression and the protection of reputation by applying Article 20 of the Criminal Act which outlines "justifiable acts". This Article precludes punishment when an act is done in accordance with other Acts and statutes, or in pursuance of generally accepted business or social practices ("customary social act"). ${ }^{111}$ For the foregoing reasons, the majority concluded that Article 311 is not unconstitutional.

103 Constitutional Court [Const. Ct.], supra note 7, at 8-9.

104 Constitutional Court [Const. Ct.], supra note 7, at 9.

105 Constitutional Court [Const. Ct.], supra note 7, at 9.

106 Constitutional Court [Const. Ct.], supra note 7, at 9.

107 Constitutional Court [Const. Ct.], supra note 7, at 10-13.

108 Constitutional Court [Const. Ct.], supra note 7, at 12.

109 Constitutional Court [Const. Ct.], supra note 7, at 1, 10.

110 Constitutional Court [Const. Ct.], supra note 7, at 1, 11.

11 Constitutional Court [Const. Ct.], supra note 7, at 11-12. Park and Kim argue that when applied in insult law cases, the concept of customary social act in Article 20, is too vague and violates "void-for-vagueness" doctrine. Kyung Sin Park \& Khayeun Kim, The Legislative Purpose of the Insult Law and a Constitutional Critique of its Application by Courts, 10 Journal OF MEdia Law, Ethics and Policy Research 441, 458-462 (2011) (in Korean). Lee posits that Article 20 of the Korean Criminal Act should be widely applied to insulting expressions against public 
The dissent, comprised of three Justices (Justice Park Han-Chul, Justice Kim Yi-Su, and Justice Kang Il-Won), strongly criticized the majority opinion, declaring that the insult law violates freedom of expression. First, the dissent argued that "the scope of «insult» as an element of a crime is excessively broad, and that all negative or derogatory expressions directed at a person may amount to insult as they are likely to undermine one's social reputation". ${ }^{112}$ As a result, the insult law reaches "not only hateful cursing of someone humiliating enough to tear down his/her character, but also satirical, humorous literary expressions that use ridicule to expose and criticize the world, the twisting of negative intentions into the form of polite expressions, and newly coined words on the internet that are somewhat coarse". 113 The dissent argued that even expressions protected by the Constitution could be punished by the provision under review. ${ }^{114}$

The dissent emphasized that the criminal punishment of insults creates a chilling effect on freedom of expression. It "limits the possibility of raising issues in social communities and addressing them constructively through free exchange of different views and criticism". 115 They added, "it will threaten political and academic statements and restrain open debate if certain negative or critical expressions on sensitive issues used in political and academic debates are branded as insult". ${ }^{116}$ Furthermore, the dissent suggested the exercise of state authority to punish such a crime should be limited to the minimum. ${ }^{117}$ They also contended that criminal punishment is excessive because a less restrictive alternative exists. They explained that "an abstract judgment or a derogatory expression can be regulated through the self-correcting mechanism of civil society or by imposing civil liability". ${ }^{118}$ Finally, the dissent noted that penalizing insults violates international human rights standards. ${ }^{119}$ Ultimately, based on the foregoing reasons, the dissent concluded that Article 311 represented an unwarranted restriction of freedom of expression. ${ }^{120}$

\footnotetext{
figures through flexible interpretation. Seong Ki Lee, A Review of Criminality on the Criminal Contempt against Police Officers, 25 Han YANG Law Review 419, 432 (2014).

112 Constitutional Court [Const. Ct.], supra note 7, at 14.

113 Constitutional Court [Const. Ct.], supra note 7, at 14.

114 Pyo agrees with the dissenting opinion of this decision in the sense that the scope of insult law is excessively broad. Pyo, supra note 103, at 18.

115 Constitutional Court [Const. Ct.], supra note 7, at 2, 15-16.

116 Constitutional Court [Const. Ct.], supra note 7, at 2, 15-16.

117 Constitutional Court [Const. Ct.], supra note 7, at 16.

118 Constitutional Court [Const. Ct.], supra note 7, at 2, 16.

119 Constitutional Court [Const. Ct.], supra note 7, at 2, 17-18.

120 Cho agrees with the dissenting opinion in this case after analyzing the decision. Kuk Cho, De-criminalization of Defamation and Insult against Public Officials and Figures Regarding Public Issues, 25 Korean Journal of Criminology 9, 32-35 (2013) (in Korean).
} 


\section{Insult to the Republic of Korea Case in 2015 (2013Hun-Ka20, case no. 4)}

The second Korean decision that will be studied in this article concerns Article 104-2 of the Criminal Act. ${ }^{121}$ This provision was inserted in 1975 under the Kushin Constitution during the dictatorship of former President of the Republic Park Jung Hee. Article 104-2 criminalizes the behavior of any Korean national who endangers the security, interests, or prestige of the Republic of Korea outside of the country by insulting the Republic of Korea or its governmental bodies. ${ }^{122}$ The article targeted communications abroad as well as communications with foreigners inside the country in order to protect the international reputation and prestige of the Republic. After the democratic movement and the new Constitution adopted in 1987, this provision was abolished in December 1988. ${ }^{123}$

The defendant in this case had written a long poem in December 1975. The poem suggested that the Republic of Korea was a country under a dictatorship, that Koreans did not enjoy even a minimal level of fundamental rights and suffered merciless repression, and that the Korean government had sent soldiers to their death in the Vietnam War for a few pennies through secret negotiations. The author shared this poem with both Japanese and American foreigners in April 1976 and April 1977. He also published a translated version of his poem in a Japanese magazine in June 1977. He was charged with insulting the Republic of Korea under Article 104-2 and Presidential Emergency Decree No. 9. He was sentenced to 3 years of imprisonment in December 1977. His appeals to higher courts, including the Supreme Court of Korea, were denied and his sentence became final in September 1978. After 34 years, he petitioned for a retrial regarding his sentence at the Seoul Central District Court in April 2013. During the retrial, he filed a motion requesting a constitutional review of Article 104-2 of the Criminal Act that had been applied in his original case. The Seoul Central District Court granted his motion and sent this case to the Constitutional Court. The Korean Court declared that the previously abolished Article 104-2 of the Criminal Act had, in fact, been unconstitutional. ${ }^{124}$ Article 104-2 read as follows: ${ }^{125}$

121 For detailed analysis on Article 104-2, see Ho Gyeong Nam Gung, Nonmoon: Kukgamodokjoee daehan gochal [Study on Insult to the Nation], 33 SEOul Law Journal 180 (1992).

122 For composing elements of Article 104-2 and decisions, see Si-Myun Koh, "Profanation to the Republic" from the Perspective of Presidential Studies; Article 104-2 of the Criminal Act - Abolished in 1988 - and Whether a Specific Article about the President by a Foreign Fournalist violates Article 70 of the Act on Promotion of Information and Communications Network Utilization and Information Protection, etc., Sabeophaengjung 2, 7 (2014).

123 Ruth Walden, Insult laws: An insult to Press freedom (World Press Freedom Committee Reston, VA. 2000), at 217.

124 Constitutional Court [Const. Ct.], supra note 8.

12519 OSCE states have criminal laws prohibiting insult of the state. Griffen, supra note 60 , at $19-20$. 
Article 104-2 (Profanation to the Republic, etc.) of the Criminal Act

(1) A Korean national who may or actually does undermine the safety, interest or dignity of the nation through insult, ${ }^{126}$ defamation, distortion, or dissemination of false facts of state institutions established by the government of the Republic of Korea or its Constitution, or through other means in a foreign territory shall be punished by imprisonment or imprisonment without prison labor for not more than seven years.

(2) A Korean national who commits acts specified in paragraph 1 by using aliens, foreign organizations, etc. in the territory of the Republic of Korea shall be punished as prescribed in paragraph 1 .

(3) The person who is guilty of acts as mentioned in paragraph 2 may also be deprived of his or her qualifications for not more than 10 years. ${ }^{127}$

The Korean Court, in a unanimous decision, held that the above article violated freedom of expression. The Court carefully reviewed whether the provision excessively restricted fundamental rights, using a four-pronged test based on the principle of proportionality: a) the restriction of a fundamental right should be have a legitimate purpose; b) the means employed should be appropriate to achieve the purpose; c) the restriction on fundamental rights should be the least restrictive; $d$ ) there should be a balance between the conflicting legal interests. ${ }^{128}$

The Korean Court first pointed out that although the purpose of Article 104-2 was to protect the security, interests, and prestige of the Republic, as stated in the legislative history, the Court questioned whether that was its genuine purpose. ${ }^{129}$ Second, the unanimous Court held that even if the claimed purpose of Article 104-2 had been genuine, criminal punishment is not an appropriate means of protecting the security, interests, and prestige of the Republic. ${ }^{130}$ In fact, Article 104-2 itself, by restricting freedom of expression, lessens the international reputation of the country and harms the interests and prestige of the Republic. ${ }^{131}$ Third, the Court pointed out that certain concepts contained in the provision, such as "any other means", "interests", or "prestige" of the Republic, are both ambiguous and excessively expansive. ${ }^{132}$ The Article also reached negative language and critical expressions

126 Although the text uses the word "profanes (모독 in Korean)", it is commonly interpreted as the same meaning as "insult (모욕 in Korean)". Nam Gung, supra note 123, at 181.

127 Translation from the decision.

128 Constitutional Court [Const. Ct.], supra note 8, at 161-163.

129 Constitutional Court [Const. Ct.], supra note 8, at 162. Nam Gung analyzed that the real purpose of this Article 104-2 intends to deter critiques against the then government. Nam Gung, supra note 123, at 183-185.

130 Constitutional Court [Const. Ct.], supra note 8, at 162.

131 Constitutional Court [Const. Ct.], 2013Hun-Ka20, Oct. 21, 2015 (27-2A K.C.C.R. 700), 705 .

132 Constitutional Court [Const. Ct.], supra note 8, at 162. Nam Gung argues that Article 
often used in political and academic debates, as well as satirical, humorous literary expressions that use ridicule to criticize the world. ${ }^{133}$ Additionally, the Court considered the following: that there are other laws that protect the security and independence of the Republic such as the Criminal Act, the National Security Act, and the Protection of Military Secret Act; that criminally punishing expressions that injure the prestige of the Republic is contrary to the spirit of democracy which both requires and guarantees the ability to freely criticize the government; and, that the Republic has sufficient resources and information available to adequately respond to false facts and malicious distortions without having to resort to criminally punishment. ${ }^{134}$ The Court also concluded that the Article breaches the rule of the least restrictive means. Lastly, the Court held that Article 104-2 does not meet the rule of balance between interests because the restriction of a fundamental right is excessive considering the importance of freedom of expression in a democratic society. ${ }^{135}$ For these reasons, the Court concluded that Article 104-2 violates freedom of expression.

As we have seen, the highest courts in both Mexico and South Korea have undertaken a focused examination of the issues surrounding the constitutionality of insult laws in their respective countries. It is now necessary to provide a comparative analysis of these decisions, focusing on the specific legal issues raised in each country's decisions.

\section{Comparative Analysis of the Decisions}

\section{Is Protecting the Dignity of the Nation a Legitimate Purpose of Insult Laws?}

In this section, I will examine the legitimacy of the various purposes offered in support of insult laws. Among the different purposes offered in the cases discussed previously in this article, I will focus here on the dignity of the nation. Is the dignity of the nation a valid constitutional interest requiring protection? If so, is it sufficient to justify the restriction the of an individual's fundamental rights? Is this, in fact, a legitimate purpose?

104-2 harms rather than promote the dignity of the nation because the harmful expressions against a nation should be responded by diplomatic and public and diplomatic relations of the government. Nam Gung, supra note 123, at 186.

133 Clooney and Webb posit that satirical expressions, as artistic expressions and social commentary, are given more protection than other expressions. Clooney \& Webb, supra note 4 , at 26 .

134 Constitutional Court [Const. Ct.], supra note 8, at 162-163.

135 Constitutional Court [Const. Ct.], supra note 8, at 163. 
The Mexican and Korean Courts have both tried to answer this question in cases arising as a result of provocative poems. The Mexican Court held that protecting the dignity of the nation was sufficient to justifiy criminal punishment for insulting the national flag (case no. 1). The prestige of the Republic of Korea was also the purpose used to justify criminalizing insults to the Republic (case no. 4).

Mexico, as a country, cherishes its national flag. In the insult to the national flag case from 2005 (case no. 1), the historical meaning of the national flag can be seen in the majority opinion's reference to the legislative discussions regarding Article 73 of the Mexican Constitution. The national flag of Mexico is generally considered to represent the tradition of fighting for justice and liberty. This purpose was not, however, unanimously accepted by the Court. The dissenting opinion argued that criminalization itself is against the very spirit of the Mexican flag. It held that a criminal norm that restricts the political meaning of the national flag goes far beyond any reasonable understanding of what is necessary to preserve public morals. ${ }^{136}$ Morales Sánchez emphasized that the Mexican Court's majority opinion did not provide a reason why the dignity of the nation justifies a limit of freedom of expression. ${ }^{137}$ And Lopéz Salas highlighted the fact that while the Mexican Constitution recognizes the honor of the nation, the official opinion of the Mexican Court did not distinguish between the honor and the dignity of the nation. ${ }^{138}$

While Mexico accepted that protecting or preserving the dignity of the nation was a legitimate purpose of insult law, the Korean Court questioned whether the dignity of the nation was the genuine purpose of their insult law in the case of insult to the Republic of Korea (case no. 4). It was clear in the motives of the draft bill that the purpose of this provision was to protect the dignity of the Republic of Korea, as well as the security and interests of the Republic. This official purpose was generally accepted by criminal law scholars at the time. ${ }^{139}$ However, in 2015, the Korean Court did not accept this official purpose as the genuine intent of this provision. In arriving at that decision, the Korean Court considered how this provision had not only been used to repress criticism and anti-governmental groups, but also the fact that it had been abolished in 1988 as part of the transition from dictatorship to democracy. Although the Korean Court did not offer further clarification, it could have announced that the actual intent of this provision was to oppress critics of both governmental policy and the President by blocking the free

136 Primera Sala de la Suprema Corte de Justicia de la Nación [SGJN], supra note 2, Voto de Minoría, at 8-9.

137 Morales Sánchez, supra note 72, at 128.

138 Salas posits that the principle of dignity exclusively protects the dignity of human beings. López Salas, supra note 66, at 443.

139 For detailed analysis about the purpose of Article 104-2, see Nam Gung, supra note 123, at 181-185. 
circulation of differing views, which had gone so far as to prevent communication with foreign media.

The historical and social context of the period when the law was effective, from 1975 to 1988 , should be considered in order to understand how the Korean Court came to discredit the alleged purpose of this provision. It was misused (or properly used if that was its real purpose) to silence critics of both governmental policies and the President. ${ }^{140}$ This offense was often called "profanation of the President" rather than "profanation of the Republic" due to the fact that it had been more widely applied to insults directed at the President. ${ }^{141}$ Although the wording of the provision purports to punish insulting expressions "outside of the country", it was interpreted by the Supreme Court of Korea to encompass the communication of insulting expressions with foreigners "inside the country", including communication with foreign journalists. ${ }^{142}$ Consequently, the elimination of this provision was proposed and debated immediately following the success of the democratic movement of 1987, which resulted in an amendment to the Constitution. This provision was finally deleted officially in December 1988 through the Special Committee for Democratic Development of the National Assembly.

Another factor to consider is that the unconstitutionality of the previously abolished insult law was not declared by the Korean Court until 2015, 40 years after the provision's initial adoption, and 27 years after having been abolished. Following the democratic movement, South Korea has developed into a vigorous democracy, ending decades of authoritarian regimes. There was no longer any external political pressure on the Korean Court to reaffirm the unconstitutionality of the restrictive clause. In fact, considering that the Korean Court, which was established by the last amendment of the Constitution, had gained the support of the public by eliminating the legacies of the past dictatorship regimes, it would be contrary to its own jurisprudencial independence if it had decided otherwise.

In my opinion, the dignity of the nation (or the Republic) is not a legitimate basis on which to restrict freedom of expression by criminal punishment. It does not belong to any category of justifiable restrictions of freedom of expression found in human rights charters or constitutions of other nations. As we have seen, generally accepted norms regarding human rights do permit restrictions on freedom of expression in cases where it conflicts with the rights (reputations) of others and the protection of national security, public order, or public morals. ${ }^{143}$ However, these do not include the dignity

140 Nam Gung points out that Article 104-2 could be applied to insulting expressions against the President as a private person not as a state authority. Nam Gung, supra note 123, at 191 .

141 Koh, supra note 124 , at 7.

142 Supreme Court of Korea [S. Ct.], 83Do515, Jun. 13, 1983.

143 Article 19 (3) of the ICCPR, Article 13 (2) of the ACHR, Article 6 of the Mexican Constitution, and Article 21 paragraph 4 of the Korean Constitution. 
of the nation. An expression insulting a nation does not harm the rights or reputation of any third person. Nor does it harm the security of a country or disturb the public order unless it involves violence. ${ }^{144}$ The meaning and extent of public morals may be different in each country depending on the social, philosophical and religious understanding of its citizens. ${ }^{145}$ In other words, whether the dignity of the nation is an element of public morals may be differently interpreted. There is sufficient room for discretion on the part of the jurists in each country on this issue. From my point of view, limitations based on public morals would be proper, for example, when regulating the level of obscenity with respect to publications directed at minors, but would not be proper with respect to regulating purely verbal expressions that in no way promote or lead to violence. Expressions insulting the dignity of the nation, in fact, do no harm. ${ }^{146}$

It is, in fact, the criminalization of "insulting" expressions directed at the national flag, national authorities, or the nation itself that does harm to the dignity and prestige of the country. ${ }^{147}$ Incorporating these types of criminal provisions into the penal code inevitably damages a country's reputation for guaranteeing freedom of expression. Indeed, when the insult to the national flag case was decided by the Mexican Court, the decision was criticized for not allowing sufficient space in the political discourse for a disrespectful poem. Criminalizing insult laws is widely regarded as being overly restrictive of freedom of expression since enforcement of these provions is often used to suppress only those opinions and views that are in opposition to the government. The Korean case of insult to the Republic is a good example of this. The criminal punishment of insulting expressions against the nation had been misused to the point that the purported official purpose, in that case protecting the dignity of the nation, was rejected by the Korean court.

Furthermore, these types of insult laws do not meet international human rights standards. The Human Rights Committee states that to lawfully restrict freedom of expression for any cause, "the precise nature of the threat, the necessity and proportionality of the specific action taken must be clearly demonstrated "in specific and individualized fashion". ${ }^{148}$ In the above cases, it would be difficult to establish that the poems caused a direct and immediate threat to the dignity of either Mexico or South Korea. Accordingly, the use of

144 Morales Sánchez posit that the poet in the national flag case did not harm any other person or moral, did not provoke any crime, and did not disturb public order or peace. Morales Sánchez, supra note 72, at 129.

145 Human Rights Comm., supra note 14, para 32.

146 Cruz Parcero posits that it is fallacious to argue that insulting national symbols harms the dignity of the nation because there is no damage to prove in this case. Cruz Parcero, supra note 40 , at 430 .

147 See also Nam Gung, supra note 123, at 186.

148 Human Rights Comm., supra note 14, para 35. 
criminal punishment, which should only be used as a last resort, is neither a necessary nor proportional means by which to regulate disrespectful expressions. ${ }^{149}$

In sum, I do not believe that the dignity of the nation is a legitimate cause to restrict insulting expressions. Nevertheless, we still live in a world, even in formally democratic societies, where political leaders and public officials are often tempted to keep people quiet and to avoid criticism. Often, they will use other insult laws, some intended for entirely different purposes, to block this criticism. I will analyze insult laws with other purposes in the next section.

\section{Insult to Public Officials: More Tolerant or More Strict?}

The dignity of the nation is not the only interest that insult laws attempt protect by criminalizing insulting expressions. In this section, I will review how other insult laws restrict expressions against public officials and how they conflict with the principle that guarantees the free circulation of ideas and expressions regarding public figures and public concerns.

In Mexican law, expressions against public officials are regulated in order to protect the exercise of a public function. Article 287 of the Penal Code for Mexico City in the insult to the authority case (case no. 2) is not the only law that regulates insults directed against public officials. Article 189 of the Federal Penal Code imposes one to six years' imprisonment in addition to that which corresponds to the crime committed. ${ }^{150}$ According to the Special Rapporteur, although Article 189 "does not refer specifically to crimes of disrespect, or desacato, against public officials, but rather to any crime against a public official, the effect is to make the penalties greater for criminal defamation, libel, and slander when these are committed against public officials than against private individuals". ${ }^{151}$ These provisions punish an offense against a public servant, agent, or authority in the exercise of his or her functions.

149 Clooney and Webb argue that proportionate civil penalties should be imposed instead of prison terms. Clooney \& Webb, supra note 4, at 40-41. The dissenting opinion of the National flag case is rooted in dominant concepts in international human rights jurisprudence. Pou, supra note 55, at 196. Salas argues that penal punishment is an excessive means to limit the freedom of expression in a plural and democratic society. López Salas, supra note 66, at 446.

150 Article 189 of the Federal Penal Code

Anyone committing an offense against a public servant of agent of authority in the act of lawfully carrying out his duties or by reason of them shall be subject to one to six years' imprisonment in addition to that which corresponds to the crime committed.

Translation from the report of the Special Rapporteur for freedom of expression on desacato laws (2000), at 65, http://werw.oas.org/en/iachr/expression/docs/reports/desacato/Desacato\%202000. $p d f$.

151 Special Rapporteur for freedom of expression on desacato laws, supra note 152, at 65, para. 22. 
Criminal punishment for insulting expressions against public officials purports to protect the exercise of some public function.

In Korean law, expressions directed against public officials are often punished because they infringe upon the honor of the public official as a private person. ${ }^{152}$ After the insult to the Republic provision was abolished in 1988, no subsequent law purported to officially punish insulting expressions directed against public officials in general. ${ }^{153}$ However, Article 311 of the Criminal Act does punish insulting expressions that violate the honor of another person, as in case no. 3. Although this provision aims to protect private persons, it has been increasingly used to protect public officials, especially police officers. ${ }^{154}$ According to the Annual Reports of the Prosecutor's Office about Crime Analysis from 2000 to 2016, the number of defamation and insult cases (crimes under Part II Chapter XXXIII, Crimes against Reputation) has increased over time, as shown in Figure 1 below. ${ }^{155}$ The increase is related to the fact that the police officers began to file cases as victims of insulting expressions after 2007. ${ }^{156}$ At that time, the Seoul Central District Police issued directives to file insulting expressions directed against police officers, and a drunken citizen was arrested for the first time for insulting a police officer in April 2007. ${ }^{157}$ Individuals who have been charged for insulting police officers and subsequently arrested on those charges are increasingly submitting petitions to the National Commission of Human Rights in Korea. ${ }^{158}$ The number of cases filed by public officials increased sharply beginning in 2007, but decreased again after 2015. ${ }^{159}$ One explanation for

152 Kim and Moon discuss about the status of police officers in insult law cases against them: as a private person and as a public officer. Min-Jung Kim and Jun-Young Moon, Reestablishment of review structure of insult law cases against police officers, 8 BUBHAKPYUNGRON 408, 437-440 (2018).

153 The exception to this would be the criminal punishment of insults in the National Assembly, courts or army in Korea. Jin-soo Chung et aL., A Study on the Korean Courts' Standards for Defamation and Insult : Focused on Defamation and Insult Decisions DURING THE Last Ten Years (2005-2015) (Korean Institute of Criminology. 2015), at 65-67 (in Korean).

154 Cho analyzed cases where Artcle 311 of the Criminal Act was applied to insulting expressions against public figures. Cho, supra note 122, at 29-35.

155 Kim and Moon show that insult cases drastically increased during past 10 years. Kim \& Moon, supra note 154, at 414-416.

156 For court decisions of insult law against police officers, Kim \& Moon, supra note 154, at 417-427.

157 Kang Ah-yeon, First Arrest for Insulting Police Officer, Seoul Shinmun (Apr. 23, 2007), http://wrere.seoul.co.kr/news/newsView.php?id=20070423007006. Constitutional Court [Const. Ct.], supra note 7 , at 17.

15890 petitions concerned those cases charged of insulting police officers from 2011 until 27 Aug 2014. Lee, supra note 113, at 420.

159 According to the 2012 Annual Report of the Prosecutor's Office, in 2000 the number of cases filed involving insult amounted to 1,858 and 532 individuals were indicted, and in 
this decrease could be the public debate that arose concerning the excessive use of arrest for insulting police officers. The National Commission of Human Rights also recommended the Commissioner-General of the Korean National Police Agency address problems with the relevant police procedures in December 2014. ${ }^{160}$

\section{Figure 1. Number of Crimes Against Reputation and the Number of Cases where Victims are Governmental Institutions or Public Officials ${ }^{161}$}

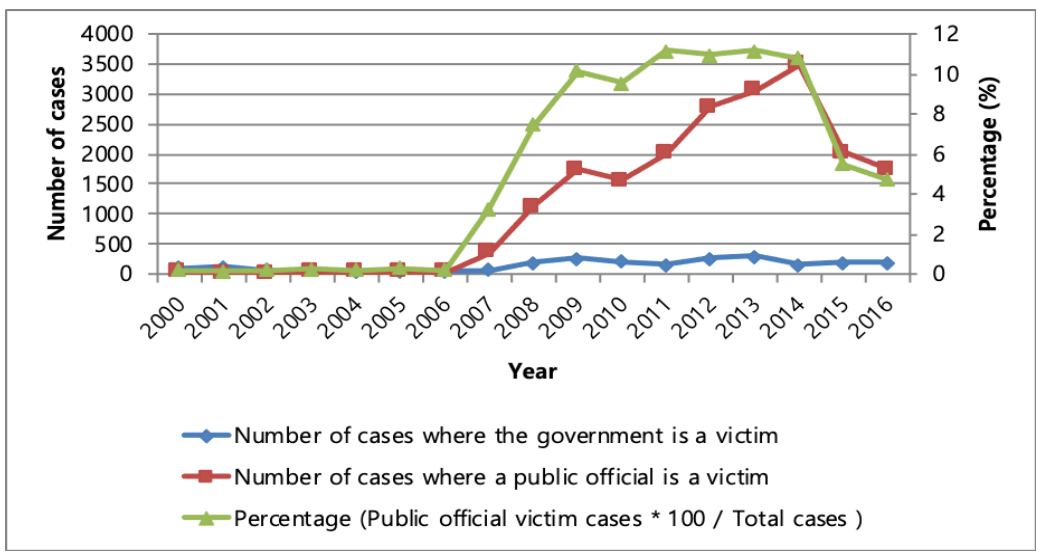

An example of the misuse of this law was the criminal punishment of a 29-year-old Army officer who criticized the then-President of the Republic of Korea, Lee Myung-Bak. He was charged for insulting a military superior by posting insulting expressions against the President of the Republic of Korea on his twitter account. The court considered the President of Republic as his military superior because the President is the supreme commander of the

2011 a total of 11,839 cases were filed and 6,260 were prosecuted. There could be many reasons for the 10 fold-increase in the number of prosecuted individuals within 11 years. Constitutional Court [Const. Ct.], 2013Hun-Ba1 11, Feb. 25, 2016 (233 K.C.C.G. 339)

160 Yonhap News Agency, Human Rights Commission of Korea, "Concerns about Human Rights Violations in cases of Arrests for Insulting Police Officers" (Dec. 9, 2014), http://werwre.yonhapnews.co.kr/ bulletin $/ 2014 / 12 / 09 / 0200000000 A K R 20141209088800004$. HTML?input $=1195 \mathrm{~m}$. For problems for prosecuting insults against police, see Lee, supra note 113, at 425.

1612001 Crime Analysis, at 246; 2002 Crime Analysis 246; 2003 Crime Analysis, at 246; 2004 Crime Analysis, at 256; 2005 Crime Analysis, at 286; 2006 Crime Analysis, at 286; 2007 Crime Analysis, at 288; 2008 Crime Analysis, at 288; 2009 Crime Analysis, at 314; 2010 Crime Analysis, at 372; 2011 Crime Analysis, at 372; 2012 Crime Analysis, at 372, 2013 Crime Analysis, at 372; 2014 Crime Analysis, at 372; 2015 Crime Analysis, at 580; 2016 Crime Analysis, at 584; 2017 Crime Analysis, at 584, available at the website of Prosecutors' Office (Korea), http://werere.spo.go.kr/site/spo/crimeAnalysis.do. 
armed forces. He was subsequently sentenced to 6 months in prison and a year of probation. In 2016, the Korean Court affirmed the constitutionality of Article 64 Paragraph 2 of the Military Criminal Act which punishes insults of a superior officer. ${ }^{162}$

Thus, expressions against public officials are still subject to criminal punishment by a separate legal provision, as in Mexico, or by extending the application of insult laws intended to protect private individuals to public officials, as in Korea. Do public officials merit more protection from insulting expressions, or should they be more tolerant of insults? If public officials are more protected from insulting expressions, is this not a breach of the principle of equality, namely, between public officials and private individuals? ${ }^{163}$

Different values may come into play regarding insult laws. There are two different perspectives that could either mitigate or aggravate the seriousness of insulting public officials when compared to insulting private individuals depending on which perspective is applied. On the one hand, the fact that the victims is a public official is a mitigating factor because it allows for free expression of criticism against them. ${ }^{164}$ The fact that the expression is about a public figures or a public concern may preclude culpability. ${ }^{165}$ For example, Article 310 of the Korean Criminal Act states that defaming expressions are not punishable when they are true and solely for the public interest. ${ }^{166} \mathrm{On}$ the other hand, the fact that a victim is a public official can be an aggravating factor because the insulting expressions not only harm the reputation of the victim, they also interfere with the exercise of a public function. The separate legal provisions that criminalize expressions against public officials allowing additional punishment, such as Article 189 of the Mexican Federal Penal Code, are based on this rationale. ${ }^{167}$

I argue that the rationale to protect a public function does not justify the criminal punishment of insulting expressions directed against public officials.

162 Constitutional Court [Const. Ct.], 2013Hun-Ba1 11, Feb. 25, 2016 (233 K.C.C.G. 339)

163 Public officials enjoy the resources to investigate and prosecute their complaints. Winfield \& Mendoza, supra note 33, at 7.

164 Yanchukova, supra note 3, at 866-868.

165 Cho argues that defamation against public figures should be decriminalized. Cho, supra note 122 , at 23-26.

166 Article 310 of the Criminal Act of Korea

If the facts alleged under Article 307 (1) are true and solely for the public interest, the act shall not be punishable.

Kim posits that the exception clause of Article 310 should be also applicable to insult law considering its defamation character. See Sang-Ho Kim, Insult and Slander in Criminal Law, JusTICE 52, 69 (2008) (in Korean). Cho argues that Article 310 should be applicable to insult law. Cho, supra note 122, 36-37.

1679 OSCE states have criminal laws that provide harsher criminal punishment to defamation or insult against a public official than those against a private person. Griffen, supra note 60, at 13 . 
It runs contrary to the principle that expressions concerning public figures and public concerns should enjoy broad constitutional protection given the importance of the free circulation of opinions and views in a democratic society. ${ }^{168}$ This principle is affirmed by the Mexican and Korean Constitutions as well as by both universal and Inter-American human rights standards.

The rationale that insulting expressions may disrupt a public function should not restrict expressions directed against public officials. Expressions that amount to "insults" are intrinsically merely an expression. When insult remains an expression such as a poem in a magazine, or a blog post on the internet, no public function is disturbed by the expression itself. If an expression involves violence that would actually and materially interrupt the exercise of a public function, other criminal provisions typically apply.

We can imagine that an assault on a police officer may be punished more severely than an assault on a private person, as it would actually disrupt the execution of the officer's official duties. However, the same logic cannot, and should not, be applied to mere expressions. Insulting words towards a police officer are not directed to him as a person but as an agent of the public entity. ${ }^{169}$ It does not harm his personal reputation. There is no damage, material or symbolic, to the public function from criticism that is merely unpleasant, disrespectful, or insulting. ${ }^{170}$

As a result, I argue that public officials should be required to tolerate a greater degree of insult than private individuals. The protection of public officials via the imposition of criminal punishment impedes societal aspirations for true freedom of expression necessary to a democratic society. The protection of a public function or the honor of a public official should not defeat the higher objective of permitting legitimate criticism of public officials and public concerns.

\section{Constitutional Standards: "Insult", Too Vague or Too Broad?}

I have examined why insulting expressions directed against public officials should be protected under national constitutions. I will now move on to the

168 "The rationale behind desacato laws reverses the principle that a properly functioning democracy is indeed the greatest guarantee of public order". Inter-Am. Comm'n H.R., supra note 26 .

169 Lee argues that whether expressions are against police officers as a private person or as public officer should be considered. Lee, supra note 113, at 426-428.

170 The Constitutional Court of Hungary declared unconstitutional Article 232 of the Penal Code that prohibited defamation and libel against public officials in the same way as those committed against private persons. The Court stated that the protection granted by criminal law to the honor of public authorities and officials is unconstitutional in that a greater degree of insult may be tolerated than in the case of private persons. Alkotmrinybir6sdg (AB) [Constitutional Court], Jun. 21, 1994, 36/1994(VI. 24.)AB (Hung.), https://hunconcourt.hu/uploads/ sites/3/2017/11/en_0036_1994.pdf. 
constitutional standards that were used in these four decisions, namely, the principle of legality (clarity) and freedom of expression.

The constitutional standards that were used by both the Mexican and Korean Courts are the principle of legality (clarity) and freedom of expression. However, the two constitutional courts applied these principles in different ways and reached different conclusions. In short, when the Mexican Court declared insults to authority to be unconstitutional, the Court based their reasoning on the principle of clarity, which is derived from the principle of legality. Meanwhile, when the Korean Court declared insults to the Republic to be unconstitutional, that Court based its reasoning on freedom of expression. A table of the conclusions of the two Courts related to each constitutional standard, the principle of clarity and freedom of expression, is shown as follows:

\section{Table 1. Conclusions of the Two Courts on Each Constitutional Standard}

\begin{tabular}{|c|c|c|c|c|}
\hline & \multicolumn{2}{|c|}{ Mexican Court } & \multicolumn{2}{|c|}{ Korean Court } \\
\hline & $\begin{array}{l}\text { Insult to the } \\
\text { national flag } \\
2005\end{array}$ & $\begin{array}{l}\text { Insult to the } \\
\text { authority } \\
2016\end{array}$ & $\begin{array}{c}\text { Insult as criminal } \\
\text { offense } 2013\end{array}$ & $\begin{array}{l}\text { Insult to the Republic } \\
\qquad 2015\end{array}$ \\
\hline $\begin{array}{l}\text { Principle of } \\
\text { clarity }\end{array}$ & $\begin{array}{l}\text { "insult" } \\
\text { Not vague }\end{array}$ & $\begin{array}{l}\text { "insult" } \\
\text { Vague } \\
\text { —violation of } \\
\text { the principle of } \\
\text { legality }\end{array}$ & $\begin{array}{l}\text { "insult" } \\
\text { Not vague }\end{array}$ & $\begin{array}{l}\text { "interests", "prestige" } \\
\text { Vague } \\
\text {-violation of free- } \\
\text { dom of expression }\end{array}$ \\
\hline $\begin{array}{l}\text { Freedom of } \\
\text { expression }\end{array}$ & $\begin{array}{l}\text { Legitimate } \\
\text { restriction }\end{array}$ & (no review) & $\begin{array}{l}\text { Not excessive } \\
\text { restriction }\end{array}$ & $\begin{array}{l}\text { Excessive restriction } \\
\text { - violation of free- } \\
\text { dom of expressions }\end{array}$ \\
\hline
\end{tabular}

Beginning with the principle of clarity, the provisions under review used the verb "insult" to describe the conduct which exposes a person to criminal liability. However, the two Courts reached their decisions differently in each case. In Mexico, the principle of clarity was more carefully discussed in the 2016 case of insult to authority (case no. 2) than in the 2005 case of insult to the national flag (case no. 1). In the insult to the national flag case (case no. 1), the First Chamber of the Mexican Court did not find "ultraje (insult)" to be a vague concept. ${ }^{171}$ However, in 2016 (case no. 2), the Full Chamber of the same Court expressed a completely different view of the same concept. The Mexican Court found the concept too vague and determined the questioned

171 Primera Sala de la Suprema Corte de Justicia de la Nación [SGJN], supra note 2, at 125127. Gama Leyva also argues that "insult (ultrajar)" in the national flag case is a vague concept. Gama Ley-va, supra note 73, at 10. 
provision to be unconstitutional. The semantic definition of the word covers a broad spectrum of conduct, and other phrases in the provision did not sufficiently or meaningfully limit its application. The Court concluded that this concept was so expansive that judicial and administrative authorities may apply the concept arbitrarily. ${ }^{172}$

The Korean Court, on the other hand, did not find "모욕 (insult)" to be a vague concept in the 2013 case of insult as a criminal offense. ${ }^{173}$ The Korean Court considered the dictionary definition as well as various academic interpretations by criminal law professors. The Korean Court held that conventional wisdom and sound common knowledge could determine whether a certain expression is an insult in any specific individual case. The Court also mentioned that there is no concern that a law enforcement agency will interpret insult law arbitrarily because the Supreme Court of Korea has provided an objective standard for interpreting the meaning of insult.

Regarding the principle of clarity, the standard applied by the Mexican Court appears to be more strict than that used by the Korean Court. The Mexican Court decided the word "insult" was too vague, while the Korean Court held that the same word is not vague and would not be applied arbitrarily by authorities. While both Courts mentioned that the common sense understanding of the public regarding insult would be considered by the authorities, the two Courts arrived at different conclusions. I do not believe this is because the word "insult" is more specific in Korean than in Spanish. Nor is the different conclusion explained by the fact that Korean authorities interpret and apply the questioned provisions more carefully than Mexican authorities. (We have seen that "unheard of nobody" is considered an insult in South Korea.) From my point of view, the word "insult" in Korean does, in fact, leave room for Korean authorities to interpret the term arbitrarily.

The different result of the Korean Court is better explained by the fact that the Korean Court tends to approach the same problem from the perspective of freedom of expression rather than the principle of clarity. When they decided the insult law was unconstitutional, the Korean Justices stated it was too broad rather than too unclear. The issue of vagueness in insult law is often considered a violation of freedom of expression, rather than a violation of the principle of clarity or legality. In the 2015 decision regarding insult to the Republic, the Korean Court considered that expressions such as "interests", "prestige," and "any other means" to be vague and, thus, too broad. ${ }^{174}$ The Court considered vagueness in terms of freedom of expression, rather than as a separate constitutional standard of the principle of legality. The Court decided that the norm breached the least restrictive means rule, which

172 Pleno de la Suprema Corte de Justicia de la Nación [SCJN], supra note 6, at 28-35.

173 For details about the meaning of "Insult", see Pyo, supra note 103, at 9-11.

174 The terms are widely used in Korean legal text. This would entail the Court to decide with more caution when deciding whether they are vague or not. 
is a consideration within freedom of expression jurisprudence. ${ }^{175} \mathrm{Also}$, in the insult as a criminal offense case in 2013, the dissenting opinion pointed out that the scope of "insult" as an element of a crime was excessively broad. The dissent argued that all negative or derogatory expressions could amount to insult as they are likely to undermine one's social reputation. As a result, the dissent warned that

...not only hateful cursing of someone humiliating enough to tear down his/ her character, but also satirical, humorous literary expressions that use ridicule to expose and criticize the world, or the twisting of negative intentions into the form of polite expressions, or newly coined words on the internet that are somewhat coarse, etc., are also punishable as a crime of insult. ${ }^{176}$

Another factor that affected the two Courts' differing approaches is the logical order of the two constitutional standards. In the Mexican Court's majority opinion in the 2016 insult to authority case (case no. 2), after finding the questioned provision unconstitutional based on the principle of clarity, that Court did not review the substantive issue of freedom of expression. It held that the petitioner had focused on the principle of legality and that this principle would have been examined first even if the freedom of expression principle had been argued. The Court referred to the fact that the InterAmerican Court had also analyzed the principle of legality first when a violation of freedom of expression was argued. ${ }^{177}$ In contrast, the Korean Court did not review the principle of clarity when it decided that the insult to the Republic law breached the principle of freedom of expression. In practice, the Korean Court also reviews the principle of legality prior to the consideration of substantive constitutional rights. However, when it declares a law unconstitutional, the Korean Court finds it sufficient to refer to the strongest reason; it is not obliged to review other principles and constitutional rights that may be raised in the case. Furthermore, from a practical standpoint, the Korean Court may prefer to review freedom of expression over the principle of clarity in order to restrict the impact of the decision on possible future cases. The Korean Court seems to consider that if it were to find a certain expression vague, it might then encounter the same constitutionality challenge

175 The dissenting opinion of the insult as criminal offense case mentioned that "insult" is too broad rather than too vague.

176 Constitutional Court [Const. Ct.], supra note 7, at 14. Satirical expressions are protected in other international human rights courts. The European Court of Human Rights held that the conviction for insulting the then French President Sarkozy by holding a placard written "Casse toi, pauv' con (Get lost, you sad prick)" is a violation of this person's freedom of speech. Eon v. France, App. No. 26118/10, (Eur. Ct. H.R. Mar. 14, 2013). Clooney \& Webb, supra note 4, at 26.

177 Pleno de la Suprema Corte de Justicia de la Nación [SCJN], supra note 6, at 35-41. 
arising from any law that contains the same word. ${ }^{178}$ If it declares "insult" to be too vague, then all laws that include the word "insult" could be considered too vague and thus unconstitutional. To avoid expanding claims of violations of the principle of legality, it may prefer to declare a specific law to be in breach of freedom of expression.

The broadness and vagueness of any law regulating expressions are, in fact, closely related. Both broad and vague terms in insult laws may violate the principle of clarity derived from the principle of legality. They may also breach substantive rights of freedom of expression at the same time. In my opinion, the latter perspective deals more closely with the core issue of these types of cases. The enhanced protection for expressions directed against public officials goes to the very essence of freedom of expression - namely, its significance in a democratic society. Herein lies the principal reason why public officials should tolerate a greater degree of insult.

Another point that should be discussed regarding freedom of expression is the "chilling effect" that such a restriction introduces. ${ }^{179}$ Specifically, criminally punishing insults chills freedom of expression. ${ }^{180}$ The possibility of arrest, indictment, and punishment deters individuals from freely expressing opinions that are not aligned with a governmental entity, whether it be a person, institution, or symbol. It restrains the open and free exchange of opinions and criticism because dissenting opinions often use negative, derogatory, and disrespectful expressions that could amount to insult. This harms the very spirit of democracy.

This impediment to open democratic debate is most certainly aggravated by the threat of criminal punishment. ${ }^{181}$ Criminal punishment is one of the state's strongest powers and should not only be used as a last resort, but should also be confined to a minimum. If there is any need to regulate a derogatory expression in order to protect either a private person's honor or the exercise a public function, it should be regulated through a self-correcting mechanism of civil society or the imposition of civil liability. These are more appropriate mechanisms for use in a democratic state which purports to guarantee freedom of expression as a fundamental goal in and of itself. When civil enforcement mechanisms are available, criminal punishment of insulting expressions

178 The Criminal Act of Korea has six other provisions that include the wording "insult". Also the Word "insult" is found in other criminal provisions in the Military Criminal Act and the Act on Testimony, Appriasal, etc. Before the National Assembly. Chung et al., supra note 155, at 65-67.

179 Winfield and Mendoza argue that criminal proceedings on insult against public officials produce chilling effect. Winfield \& Mendoza, supra note 33, at 7.

180 Yanchukova, supra note 3, at 893. Park and Kim also posit that insult law punished by Article 311 of the Criminal Act in South Korea seriously creates chilling effect on free expressions. Park \& Kim, supra note 113, at 458-462.

181 Yanchukova, supra note 3, at 893. 
is neither a necessary nor legitimately proportional restriction. Rather, it is an excessive restriction which violates the essence of freedom of expression.

\section{Conclusions and Suggestions}

In conclusion, criminally punishing insulting expressions against public officials violates freedom of expression. The dignity of the nation is not a legitimate interest upon which to base the restriction of insulting expressions. Nor do other purported interests, such as the protection of public function or the honor of a public official, justify this excessive restriction on freedom of expression. Public officials should be required to tolerate a greater degree of insult than private individuals. Thus, the criminal restriction of expressions directed against public officials is contrary to the the underlying principle of freedom of expression so important in a democratic society.

Based on the above conclusions, I argue that criminal punishment for expressions directed against public officials and entities should be removed from the criminal code. ${ }^{182}$ The insult law regulating expressions insulting to the national flag, such as Article 191 of the Federal Penal Code of Mexico, or Article 105 of the Criminal Act of Korea (Profanation of National Flag or National Emblem), should be abolished.

Furthermore, the provisions that criminalize insults to authority should be also removed. There are two ways this could be done. For example, Article 287 of the Penal Code for Mexico City punishes insults to public officials. This provision has been declared unconstitutional by the Mexican Court and was not applied in the case under examination, but it is still present in the Penal Code for Mexico City. A second instance is Article 189 of the Federal Penal Code of Mexico which imposes aggravated sentences of imprisonment when a crime is directed against a public official. Both of these provisions should be amended so that they do not apply to insult law (as well as libel and defamation).

If a certain act actually interferes with the exercise of a public function and there is a legitimate need to punish those acts, then they should be punished for that specific reason, not for insult to authority. For example, Article 136 of the Korean Criminal Act specifically provides criminal punishment for a person who uses violence or intimidation against a public official engaged in the performance of his duties. ${ }^{183}$ Article 311 of the Korean Criminal Act, a general provision defining insults against private persons as a criminal of-

182 Yanchukova, supra note 3, at 894.

183 Article 136 (Obstruction of Performance of Official Duties) of the Criminal Act of Korea:

(1) A person who uses violence or intimidation against a public official engaged in the performance of his duties shall be punished by imprisonment for not more than five years, or five not exceeding ten million won. 
fense, should not be applied to expressions against public officials. ${ }^{184}$ If a disturbance occurs, Article 136 of the Korean Criminal Act should apply instead of Article 311.185 The Korean authorities should not deviate from Article 136, a special law, by applying a general law, Article 311, which has less stringent requirements for criminal punishment. ${ }^{186}$

Legislative amendments to the criminal codes would be an unequivocal way to resolve these problems. If those changes are not possible in the near future, I argue that the judiciary and governmental authorities should not apply insult laws in criminal cases regarding expressions directed against public officials. Both countries have constitutional theories accepted by their highest courts which are designed to protect expressions against public officials. These theories should be applied to insult laws rather than criminally punishing expressions against public officials. ${ }^{187}$

Insulting a nation or a public official should not be criminalized. The legislative amendments and judicial interpretations that $\mathrm{i}$ suggest are neither impossible nor impractical. Mexico and South Korea are societies with open public forums that could adequately accommodate and respond to insulting expressions. Additionally, there are other legal mechanisms and social mechanisms better suited to regulate such expressions if there is a need. Eliminating insult laws would not harm, but rather strengthen, democratic society in both Mexico and South Korea.

The constitutions of Mexico and South Korea do protect freedom of expression. The high courts in the two countries interpret their respective constitutional provisions to acknowledge the importance of freedom of expression in a democracy. Nevertheless, there exist problematic laws that prohibit expressions that insult the state or public officials in both countries. The high courts have reached different conclusions in two cases in each country: one in favor of freedom of expression, the other in favor of other values, such as the dignity or proper functioning of the state. First of all, insult laws, especially insult laws that prohibit expressions directed against a state or its public

184 I believe that Article 311 of the Korean Criminal Act that criminalizes insult in general way should be abolished. As this paper restricts itself on the expressions against public officials, I argue that this provision, at least, should not be applied to public officials.

185 For analysis of the relationship between the two articles in Korean court practice, see Chung et al., supra note 155, at 79-80.

186 Lee posits that applying Article 311 to insulting expressions against public officials circumvents stricter requirements in Article 136 of the Korean Criminal Act that specifically provides criminal punishment for a person who uses violence or intimidation against a public official engaged in the performance of their duties. Lee, supra note 113, at 425.

Pyo argues that Article 311 should be abolished eventually. Pyo, supra note 103, at 37-39.

187 One way for South Korean courts is to apply Article 310, which provides exception for public interest, to insult law cases. Kim argues that the public interest in insult law cases against public figures, especially against elected public officials, should preclude criminality considering the right to know of general public. Kim, supra note 168, at 69. 
officials, should be abolished. If they are not abolished in their entirety, the high courts should at least allow for the fullest understanding of freedom of expression by protecting the freedom to insult the state, state symbols, and public officials. The high courts should declare insult laws, and the application of insult laws, to be unconstitutional. It is the role of the courts to make the letter of the law more closely reflect the values of a democratic society in practice.

Insult laws currently exist in other countries besides Mexico and South Korea. Journalists face imprisonment for insulting government officials and state institutions in more than 100 countries. ${ }^{188}$ In a 2017 study examining defamation and insult laws in the 57 participating States of the Organization for Security and Co-operation in Europe (OSCE), 36 OSCE states were found to have criminal laws prohibiting insult and/or desecration of state symbols, ${ }^{189} 9$ OSCE states have criminal laws that provide harsher criminal punishment for defamation or insult against a public official than against a private person, ${ }^{190}$ and 19 OSCE states have criminal laws prohibiting insult of the state. ${ }^{191}$ A report published in 2012 notes some progress in abolishing insult laws and criminal defamation in Africa, acknowledging, however, that there is much more room for improvement. ${ }^{192}$ In Latin America, desacato laws have been repeatedly identified as violating freedom of expressions in regional human rights law. ${ }^{193}$ In Asia, the Middle East, and Northern Africa, restrictions are routinely imposed on bloggers, journalists, and television stations for critical expressions. ${ }^{194}$ Additionally, the countries in the Southern African Development Community also continue to use insult laws against critics of public officials. ${ }^{195}$

While the cultural context of insult laws may vary from country to country, the basic value of freedom of expression in democratic societies is commonly shared. The challenges and successes of the various legal arguments raised in insult law cases give guidance to scholars, lawyers, and activists in their efforts to promote the free circulation of critical expressions and overcome the abusive use of insult laws in many countries. Insult laws should not be used as a means to silence critical expressions in any place in the world.

188 Ruth Walden, supra note 125, at 7. Winfield and Mendoza posit that the penalties against a journalist for insult are very severe including imprisonment and banishment from journalism. Winfield \& Mendoza, supra note 33, at 7.

189 Griffen, supra note 60, at 20-21.

190 Griffen, supra note 60, at 13.

191 Griffen, supra note 60, at 19-20; Yanchukova, supra note 3.

192 Raymond Louw, Introduction Furthering a Family Affair, in McCracken, supra note 4, at 2.

193 See the reports from the Inter-American System of Human Rights in I.(2) of this article.

194 McCracken, supra note 4, at 108, 142.

195 Balule, supra note 4. 


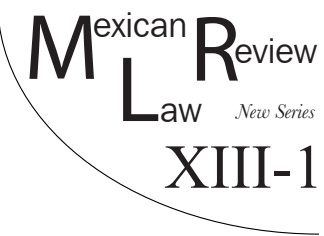

\title{
THE ARCHETYPAL MERCHANT IN THE 1889 MEXICAN GOMMERGIAL CODE*
}

\section{Raúl ITURRALDE GONZÁLEZ**}

\begin{abstract}
When creating laws, legislators bear in mind the subjects whose activities are to be regulated. This mental picture will affect the regulation of both, the subjects and their activities. Different perceived characteristics can be regulated in various ways. While the laws that regulated commerce in Mexico before 1889 were based on the concept of an honest merchant, the Commercial Code enacted by then President Diaz had a different archetypal merchant. Since 1889, commercial lawes in Mexico have been enacted based on the idea of an untrustworthy merchant, someone who needs to be regulated and controlled, which has created a regulatory system riddled with unnecessary costs. Through the study of cases decided shortly after the enactment of the 1889 Code, the change in the perception of merchants and commerce becomes apparent. These cases show the strict application of rules in lieu of commercial customs and practices, and the idea of protecting those who are not merchants in their dealings from those who are. However, these ideas should be eliminated from commercial laws. The laws that regulated commerce in Mexico before the 1889 Code offer an excellent starting point for the reform of commercial laws. Lawes that assume that merchants are honest and capable of regulating their own affairs will advance commerce in Mexico, which would in turn allow the country to become an innovator (as opposed to a follower) in commercial matters.
\end{abstract}

KEYwORDs: Archetype, commerce, merchant, customs and practices.

* This article is based on my thesis and part of my dissertation for the LLM and SJD programs at the University of Arizona James E. Rogers College of Law (2014-15, 2015-18). Part of the research was also used in a paper by Raul Iturralde Gonzalez entitled The Need to Remove the Civil Code from the Mexican Commercial Laws, The Case of Offers and Firm Promises, 10 Mex. L. Rev. 21 (2017).

** Doctor of Juridical Science from the University of Arizona. Professor at Escuela Nacional de Estudios Superiores Unidad Juriquilla (UNAM) (dr.rauliturralde@gmail.com). Former Visiting Fellow at City University of Hong Kong (Aug. 2018-June 2019). The author would like to thank the Kozolchyk National Law Center (http://natlaw.com) and its president and founder, Dr. Boris Kozolchyk (dissertation director), for their help in the research of this article. 
Resumen: Durante la creación legislativa, el legislador tendrá una idea mental de los sujetos cuyas actividades serán reguladas. Esta idea mental afectará la regulación de los recipientes y sus actividades. De esta forma, diferentes cualidades dadas a estos sujetos se regularán de manera diferente. Esto se observa en la regulación mercantil que existía en México antes de la aparición del Código de 1889. Antes de esa fecha, la idea que se tenía en la regulación mercantil era la de un comerciante honesto. Sin embargo, desde la promulgación del Código de 1889, la idea que se ha plasmado en la legislación mercantil es la de un comerciante no fidedigno, alguien que debe ser regulado y controlado. Esto ha conllevado a la creación de un sistema mercantil plagado de costos innecesarios. El estudio de decisiones judiciales dadas poco después de la promulgación del Código de 1889 hace aparente el cambio de actitud. Estos casos demuestran el intento por proteger a los no mercantes y la aplicación estricta de reglas en lugar del uso de prácticas y costumbres mercantiles. Sin embargo, estas actitudes deben ser removidas del derecho mercantil mexicano. Las leyes que regularon el comercio en México antes de 1889 ofrecen una buena base para la reforma mercantil. Leyes que se basan en la idea de un comerciante honesto capaz de autorregularse promueven el desarrollo comercial. Esto permitiría a México el convertirse en un innovador (en lugar de simplemente copiar a otros) en cuestiones comerciales.

Palabras Clave: Arquetipo, comercio, comerciante, costumbres y prácticas.

\section{TABle of Contents}

I. INTRODUCTION

II. ARCHETYPE.

III. The Merchant .

IV. Historical Background of the Mexican Commercial Code OF 1889

V. The Archetypal Merchant in Mexico before the Commercial Gode of 1889

1. The Archetypal Merchant in the Ordenanzas of Bilbao.....

2. Examples of Archetypical Merchants Used in Cases before the Enactment of the Commercial Code of 1889.

VI. The Archetypal Merchant in the Mexican Commercial

Code of 1889

1. The Influence of French Doctrine

2. The Archetypal Merchant in the Mexican Commercial Code of 1889

3. Examples of the Archetypal Merchant in Case Law

A. Successors of Bustamante J.A. v. Romano Pedro

B. Murguía v. La Mexicana, Compañía Anónima Nacional de Seguros de Vida 
C. Compañía del Ferrocarril Mexicano v. Luis Lack

\section{INTRODUCTION}

This article is a study of the merchant archetype used in the Mexican Commercial Code of $1889,{ }^{1}$ which is the Commercial Code (with many reforms) ${ }^{2}$ that currently governs commercial transactions in Mexico. The inclusion or exclusion of commercial archetypes, practices, and principles can affect the development of not only positive law, but also commerce within a country.

The work written by Dr. Boris Kozolchyk, Comparative Commercial Contracts, elaborates on this type of studies ${ }^{3}$ by examining the history and processes behind the enactment of important commercial texts, including the French Code de Commerce and the German civil and commercial codes. His study points to the possible effects of creating a positive law based on commercial principles, customs, and commercial archetypes on a country's or a region's economy. ${ }^{4}$

For example, as to the negative effects of an archetype based on a "bad man" or an "infamous witness", Dr. Kozolchyk indicates that:

Imagine, for example, the cost incurred by the holders of checks about to be deposited with their banks if the bank's presumption was that their check depositors were (a la Holmes) the "bad men of checks". Such a presumption assumes that check depositors had acquired them in bad faith and that it was their burden to prove that they did not steal, embezzle or fraudulently procure and endorse them. Aside from the high cost of such a negative proof, check depositors could no longer count on receiving provisional credits for their deposited checks as is normally received by check depositors under existing law and practice. ${ }^{5}$

1 Código de Comercio [Cod. Com.] [Commercial Code], as amended, Diario Oficial de la Federación [D.O.], October 7-December 13, 1889, Art. 2 (Mex.).

2 See Cámara de Diputados, Código de Comercio, LXII Legislatura, http://rerercediputados.gob. $m x /$ LeyesBiblio/ref/ccom.htm (last updated March 28, 2018).

3 Boris Kozolchyk, Comparative Commercial Contracts: Law, Gulture and EcoNomic Development 332-340 (2014).

4 " $[\mathrm{B}] \mathrm{y}$ archetypal behavior, I mean the representative behavior of average merchants, bankers or professionals as reflected in their standard practices as well as in the practices of highly respected and trusted merchants, bankers or professionals, to which I refer as their best practices". Id. at 39.

5 Id. at 41. Kozolchyk takes the example of an "infamous witness" from Andres Bello, and the "bad man" from Justice Oliver Wendell Holmes Jr. Id. at 40-41. 
Dr. Kozolchyk's ideas on archetypes and his comparative study of the treatment given to commercial law in different jurisdictions, like France, Germany, the United States, and Mexico, will be used as basis of study for this article.

The different treatment given to merchants and commerce in general can be seen when comparing the French Code de Commerce and the German codes. As will be explained later, ${ }^{6}$ the French code reflects the negative view, shared by Napoleon, that French society had regarding merchants and commerce in general. This negative view was so widespread that merchants who found fortune tended to pay their way into nobility as a way to eliminate the stigma of being of merchant origin. ${ }^{7}$

In contrast to the French experience, the attitude in Germany regarding commerce was the opposite, as seen in its approach to charging interests in commercial transactions. As Dr. Kozolchyk explains, post-reformation Germany was not burdened with concerns about sinful usury, ${ }^{8}$ and this had a tremendous effect on the development of commercial law in Germany.

Dr. Kozolchyk explains the differences in the development of negotiable instruments as means of payment between Germany and countries such as France and Spain. ${ }^{9}$ While negotiable instruments developed as contracts of exchange in legislations based on the French Code de Commerce, these mechanisms followed a distinct evolution thanks to the efforts of commercial law doctrinaires who used commercial practices as the core of their writings. ${ }^{10}$

According to Dr. Kozolchyk, the dissimilarity in the development of negotiable instruments arises from the attitudes that legislators had regarding merchants and commercial law. ${ }^{11}$ Those commercial laws that are free from negative attitudes towards commerce and are based on commercial principles, customs, and practices will further development. ${ }^{12}$ Unfortunately, that was not the way the Mexican Commercial Code was designed.

6 See infra "The Influence of French Doctrine".

7 See Kozolchyк, Comparative supra note 3 at 270-271.

8 " $[\mathrm{U}]$ nlike the concern for usury that prevailed in pre-codification France and Spain, commercial and consumer credit did not evoke the fear of prosecution in pre-codification Germany. Not surprisingly, toward the end of the eighteenth century it was neither illegal nor immoral in Germany and Italy to pay interest on periodic payments such as contracts of annuities that fluctuated between four and five percent per annum". Id. at 384 .

9 Id. at 385-391.

10 “[]n 1839 ... Dr. Karl Einert, a law professor and commercial court judge, provided the proper direction for Germany's (and many other nations') negotiable instruments law in his monograph, "The Law of Bills of Exchange and the Everyday Needs of the Bill of Exchange Business in the Nineteenth Century". In it, he attacked the theory of the Code de Commerce that bills of exchange were part of the contract of exchange...". Id. at 390.

11 See id. at 390-391.

12 "Commercial credit and access to investment capital became major engines of Germany's commercial and industrial growth during the middle of the nineteenth century. At the 
As I will explain in this article, the Commercial Code was designed as a response to the conditions of its time. ${ }^{13}$ Mexican legislators attempted to bring order to a country that had experienced almost a century of internal fighting and even invasions, ${ }^{14}$ and so, based the Commercial Code on (among others, but especially) the French Code de Commerce. ${ }^{15}$ Unfortunately, Mexican legislators dismissed the prevailing legislations that had been used up to that time.

These de facto legislations included some drafted by merchants themselves, which were based on commercial archetypes and practices that reflected the manner in which merchants conducted their business. These archetypes should be brought back to the core of modern commercial legislations.

\section{ARChETYPE}

Defining an appropriate archetype is important as it will be the basis of the whole system. Moreover, archetypes reflect the attitudes and values of a society or of the legislators. ${ }^{16}$ An archetype is defined by Black's Law Dictionary as "the original form from which a copy is made". ${ }^{17}$ While not usually given much importance when studying law, ${ }^{18}$ the truth is that archetypes have always been present in law; it is possible to find them all the way back to ancient Roman times.

Dr. Kozolchyk describes the use of an archetype used by Roman jurists when discussing contractual clauses, ${ }^{19}$ the "bonus vir", which is described as "an honorable man" who gives his opinion of a condition in a contract. ${ }^{20}$ For Dr. Kozolchyk, this was not the only archetype used in Roman law, as the Romans had an "archetypal pattern of transactional selfishness" that affected the development of commerce. ${ }^{21}$

\footnotetext{
same time, following the German French war, Germany emerged as an important financial center for what Braudel referred to as "high commerce" as well as for large industries and railroads". Id. at 391-392 (citations omitted).

13 See infra "Historical Background of the Mexican Commercial Code of 1889".

14 See infra "Historical Background of the Mexican Commercial Code of 1889". Also, infra note 71.

15 See infra "The Influence of French Doctrine". Also infra note 98.

16 Idea from Dr. Boris Kozolchyk. See Letter from Boris Kozolchyk to Raul Iturralde Gonzalez (Feb. 19, 2018) (on file with author).

17 Black's Law Dictionary 106 (6th ed. 1990).

18 Compare the definition given in the $6^{\text {th }}$ edition of the Black's Law Dictionary supra note 17 and accompanying text with the fact that the $8^{\text {th }}$ edition does not give a definition of "archetype”. Black's Law Dictionary 113 (8th ed. 2004).

19 Kozolchy, Comparative supra note 3 at 109.

20 Cuerpo del Derecho Civil Romano Primera Parte Instituta-Digesto 18.1.7 (D. Ildefonso L García del Corral trans., Jaime Molinas ed., 1889) in Kozolchyк, Comparative supra note 3 at 130 (translation by Kozolchyk).

21 KozolchyK, Comparative supra note 3 at 112.
} 
Therefore, defining an archetype is important as it will define the treatment given to subjects of the law, such as merchants. An example that illustrates the creation of archetypes is the famous 1960 Frigaliment case, ${ }^{22}$ in which Judge Friendly wonders how a merchant would act when presented with an ambiguous contract term.

In Frigaliment, after wrestling with different ways to define the contractual term "chicken," Judge Friendly indicates that the "[p]laintiff must have expected defendant to make some profit-certainly it could not have expected defendant deliberately to incur a loss" ${ }^{23}$ By questioning this, Judge Friendly was not asking what a regular person would expect from this transaction; rather, he was asking what a reasonable merchant would understand by the word "chicken" in a commercial contract. ${ }^{24}$

Accordingly, Judge Friendly had in mind an archetypal merchant, which is evidenced by his reminder that "when one of the parties [of the contract] is not a member of the trade or other circle, his acceptance of the standard must be made to appear by providing either that he had actual knowledge of the usage or that the usage is generally known in the community". ${ }^{25}$

Even though the Frigaliment case is a clear example of the use of archetypes, it is too general as it illustrates the minimal expectation of a regular merchant. ${ }^{26}$ For a more specific type of archetype, consider the cooperative banker that negotiates letters of credit. ${ }^{27}$ An analysis of this type of archetypical merchant goes beyond the scope of this article; nevertheless, a brief description would be that a banker negotiating letters of credit has to consider that, in later transactions, he may be in the opposite position and any conduct (either good or bad) can be reciprocated. ${ }^{28}$ These types of merchants

22 Frigaliment Importing Co. v. B.N.S. Int'l Sales Corp., 190 F. Supp. 116 (S.D.N.Y. 1960) [hereinafter Frigaliment].

23 Id. at 120. This analysis and the linkage with the concept of reasonableness was performed by Dr. Boris Kozolchyk, see Kozolchyк, Comparative supra note 3 at 18, 58, 59, 1027, 1030 .

24 "[T] sold poultry based not upon their «eye and hand» inspection, but upon the types of chicken described in catalogues or other printed descriptions of their key features." Kozolchyк, ComPARATIVE supra note 3 at p. 1030 (2014). For an in-depth analysis of this case see $i d$. at 1027-1031.

25 Figaliment, 190 F. Supp. at 119.

26 Idea from Dr. Kozolchyk, Letter supra note 16.

27 See "Negotiation means the giving of value for Draft(s) and/or document(s) by the bank authorised [sic] to negotiate. Mere examination of the documents without giving of value does not constitute a negotiation". Uniform Customs and Practices for Documentary Credits, ICC Publication No. 500 (1993), Art. 10(b)(ii).

28 Analysis carried out by Dr. Kozolchyk et al in the reforms of UCP 500. See Letter from Boris Kozolchyk to Salvatore Maccarone 7 (May 30, 1990) (Joint Position on First 20 UCP articles) (emphasis on original) (on file at Kozolchyk National Law Center, wwrenatlaw.com). See also "This interchangeability incorporates, organically so to speak, a marketplace standard of fairness as the governing standard of correspondent banks' transactions. The issuing banker 
should be considered archetypes and their practices incorporated into commercial legislation.

An example of these types of archetypes in the drafting of statutes is given in Article 8(2) of the United Nations Convention on Contracts for the International Sale of Goods. ${ }^{29}$ This article indicates that "statements made by and other conduct of a party are to be interpreted according to the understanding that a reasonable person of the same kind as the other party would have had in the same circumstances". ${ }^{30}$ This wording refers to an archetype by pointing to a hypothetical third person, which in this case is a reasonable hypothetical person operating under the same circumstances as the other party. ${ }^{31}$

By archetypal behavior, as it relates to merchants, Prof. Kozolchyk denotes "the representative behavior of average merchants ...as reflected in their standard practices as well as in the practices of highly respected and trusted [or fiduciary types of] merchants....".32 The commercial behavior of these hypothetical persons should be taken into account when enacting legislation or when compiling widely used usages of trade, as for example the Uniform Customs and Practices for Documentary Credits. ${ }^{33}$

It is important to determine the archetype legislators have in mind when enacting a statute, since the qualities ascribed to the archetype will establish the type and volume of regulation imposed on the activity. In other words, depending on the level of trust accorded to the regulated class (in this case, the merchant class), legislators will impose greater or lesser control (or supervision) over said class. ${ }^{34}$

who questions whether his confirming banker acted properly when paying or checking documents can obtain his answer by asking himself: What would I have done as an archetypal confirming bank?" KozolchyK, Comparative supra note 3 at 1051.

29 United Nations Convention on Contracts for the International Sale of Goods [CISG] Art. 8(2), Apr. 11, 1980, 1489 UNTS 3, 19 ILM 671, http://werere.uncitral.org/pdf/english/texts/ sales/cisg/V1056997-CISG-e-book.pdf. Dr. Kozolchyk had noted the use of archetypes in CISG as he had discussed the use of commercial reasonableness with the chief drafter of CISG, John Honnold. Kozolchyк, Comparative supra note 3 at 950, 977.

30 CISG $\S 8$ 8(2) (emphasis added). Kozolchyк, Comparatrve supra note 5 at p. 950, 977.

31 See Kozolchyк, Comparative supra note 3 at p. 950.

32 Id. at 39.

33 Uniform Customs and Practices for Documentary Credits, ICG Publication No. 500 (1993).

34 E.g. "[C] $]$ ommercial archetypes help the legislator or judge to establish the reasonableness of the terms and conditions of a commercial contract, including its prices." KоZOLCHYк, Comparative supra note 3 at 18. Also, "Once the lawmaker becomes aware of how such a business is conducted, he should assume the merchants' skill, decency, good faith, and willingness to emulate the behavior of respected peers...". As a commercial legislator or adjudicator, then, you need not spend much time writing detailed rules on how the good guys should conduct their business. You should spend your time as a legislator "roping off" the bad guys. These are the ones who act dishonestly and in bad faith, who take advantage of their clients' innocence 


\section{The MERCHANT}

An important distinction has to be made about the meaning of merchant. For a long time, there was a difference between people who took part in international trade and commerce in large quantities and those who sold their merchandise locally. As an example, Ruiz Guerra points out that not everybody could be a member of an officially recognized association of merchants such as Spain's Universidad de Comerciantes; 35 only those who "participated in 'high commerce" could be part of the Universidad, i.e., those who "transport and sell in large quantities, move merchandise between territories by sea and land, and do so on a consistent basis". 36

In explaining the privileges given to these merchants in Spanish legislation, Solórzano Pereyra says that:

[T] hose who from their homes and stores purchase and sell [merchandise] at the retail level, and who do not [therefore] expose themselves to shipping and other risks... should not nor do enjoy the above-mentioned privileges and protections, unlike those who transport and sell [merchandise] at a wholesale level and engage in trade between territories by land or sea... ${ }^{37}$

María del Refugio Gonzalez explains that the status of "mercader" was acquired only after being registered with the Consulates. ${ }^{38}$ This means that the treatment of merchants was based on the person's commercially licensed status - i.e. registered status - and not necessarily on the "acts of commerce" performed by said person.

or of their colleagues' mistakes or of the gaps or ambiguities in the law". Interview with Karl Llewellyn \& Soia Mentschikoff, in id. at 447.

35 See infra "Historical Background of the Mexican Commercial Code of 1889".

36 Ruben Ruiz Guerra, El Consulado de Comerciantes de la Ciudad de Mexico, in Memoria del III Congreso de Historía del Derecho Mexicano 620 (José Luis Soberanes Fernández Coord., Instituto de Investigaciones Jurídicas UNAM 1983) http://biblio.juridicas.unam.mx/ libros $/ 2 / 700 / 40 . p d f$.

37 " $[\mathrm{N}]$ o deben gozar, ni gozan de los privilegios e inmunidades referidas, los que estándose en sus casas y tiendas, sin exponerse a navegaciones y otros peligros, las compran y venden por menudo [las mercancias] ....sino los que cargan y venden por grueso y trafican para esto de unos Reynos a otros por mar o por tierra...”. Juan de Solórzano y Pereyra, Política Indiana Compuesta por el Señor Don..., in María del Refugio González Comercio y Comerciantes en la Legislación y la Doctrina Mexicanas del Siglo XIX, II Anu. Mex. Hist. Derecho 115, 119 (1990) http://wrere.juridicas.unam.mx/publica/rev/indice.htm? $r=$ hisder $\mathcal{E}_{n}=2$ (translation by author).

38 The Consulates will be explained later in this book. See infra Section "Historical BACKground of the Mexican Commercial Code of 1889". María del Refugio González, supra note 37 at 119-20 (citing Juan de Solórzano y Pereyra, who wrote in the 18th century). Moreover, María del Refugio González indicates that registry was of "capital importance" during the $16^{\text {th }}$ and $17^{\text {th }}$ centuries. $I d$. at 120. 
In an attempt to liberalize the practice of commerce, a scholarly and professional movement in Mexico proposed eliminating the subjective approach to commercial regulation and replacing it with an "objective" method based on the so-called "acts of commerce" performed by the individual and not on whether this individual was a member of a guild or a group. ${ }^{39}$ This evolving change in attitude is illustrated by the fact that the last code in Mexico that classified merchants subjectively was the 1854 "Lares" Code, which divided them into "major" and "minor" merchants. ${ }^{40}$ The Commercial Code of 1889 not only does not make this distinction, but also indicates that its provisions apply to persons who would not have been considered merchants under the old regime of commerce regulations. ${ }^{41}$

This differentiation is important as it seems that most of the resentment against merchants and their privileges was aimed at those who were members of the Consulates and not those who sold merchandise locally. ${ }^{42}$ It is important to bear in mind that the archetypes and regulatory ideas were sharply different in the two principal commercial enactments that have governed

39 See Jorge Barrera Graf, Evolución del Derecho Mercantil en México en el Siglo XIX, Hasta el Código de Comercio Vigente de 1890 in I Memoria del IV Congreso de Historia del Derecho Mexicano 111, 114 (Instituto de Investigaciones Jurídicas UNAM 1986) http://biblio.juridicas. unam.mx/libros/2/721/12.pdf.

40 The distinction was based on the amount that merchants lent or spent. This distinction was important as the code waived the need for being licensed for minor merchants. Id. at 138. See also infra "Historical Background of the Mexican Commercial Code of 1889". This was also the approach taken by the German Commercial Code. Kozolchyk, Comparative supra note 3 at p. 423.

41 Art. 4. "Those persons who incidentally, with or without a fixed establishment, perform any commercial transaction, even if they are not regarded as merchants by law, are, nonetheless, subject to the laws of commerce that govern said transaction. Therefore, laborers and manufacturers and generally all those who have established shops or stores in a population for selling the products of their farms, or the products made by their industry or craft, without undergoing any alteration upon the sale thereof, shall be regarded as merchants as far as their shops or stores are concerned". [Art. 4. "Las personas que accidentalmente, con ó sin establecimiento fijo, hagan alguna operación de comercio, aunque no son en derecho comerciantes, quedan, sin embargo, sujetas por ella á las leyes mercantiles. Por tanto, los labradores y fabricantes, y en general todos los que tienen planteados almacén ó tienda en alguna población para el expendio de los frutos de su finca, ó de los productos ya elaborados de su industria ó trabajo, sin hacerles alteración al expenderlos, serán considerados comerciantes en cuanto concierne á sus almacenes ó tiendas"].

Código de Comercio [Cod. Com. 1889] [Commercial Code 1889], Art. 4, Diario Oficial del Supremo Gobierno de los Estados Unidos Mexicanos [now Diario Oficial de la Federación], October 7-December 13, 1889 (Mex.) http://wrerw.diputados.gob.mx/LeyesBiblio/ref/ccom. htm (translation by author) (original code with no reforms).

42 "Despite the religious and social acceptability accorded to merchants devoted to «high commerce»..., Cato's ...view of the merchant as inferior in morality to the farmer-soldier was quite popular in Spain during medieval times and in the centuries that followed, almost to the present day". KozolchyK, Comparative supra note 3 at p. 145 (internal citations omitted). 
Mexican commerce. Furthermore, while these concepts, rules, and regulations were clearly designed for different types of merchants, they were nevertheless applied interchangeably to all of them.

\section{Historical Background of the Mexican Commercial Code of 1889}

An analysis of the history of the Commercial Code of 1889 reveals many of the changes needed to adjust the regulatory regime of a guild-based commerce law for it to become a governing mechanism for "acts of commerce", regardless of who performed them (guild members or not), and as intended by the French Code de Commerce of 1807. ${ }^{43}$ This analysis also shows the alterations the archetypal merchant sustained in the eyes of legislators and legal scholars.

Regardless of the fact that commerce in pre-independence Mexico was clearly a monopoly of the Spanish Crown and Spaniards, ${ }^{44}$ the discussion below will focus on the regulation of commerce by the Consulates, which ruled commerce in New Spain until some years after the Mexican independence. ${ }^{45}$ Nevertheless, their influence was still felt in the regulation of commerce until the enactment of the 1884 and 1889 Commercial Codes. ${ }^{46}$

The Consulates were the jurisdictional branch of merchant guilds in Spain and the Spanish colonies. ${ }^{47}$ Acting as guilds that enacted their own rules, called Ordenanzas, ${ }^{48}$ the merchants themselves regulated their trade. Thus, during a long period of Mexican history, custom played an important role in the regulation of commerce through the use of these Ordenanzas. ${ }^{49}$

By creating Consulates, merchants wanted "to promote the creation of a court where all controversies and disputes between merchants of these provinces could be decided according to merchant rules and practices, thereby avoiding litigation and delays" ${ }^{50}$ Consulates decided on all matters that af-

43 The subjective system was, however, not eliminated completely. See María del Refugio González, supra note 37 at 149.

44 See Barrera Graf, supra note 39 at 114-116.

45 Id. at 128.

46 Id. at $120-121$.

47 See Ruiz Guerra, supra note 36 at 619.

48 See id. at 619.

49 Ruiz Guerra explains that "[i]t is true that the sole activity regulated by the Ordenanzas was judicial. However, the rest was allotted to the guild by convenience, custom, and contracts entered into with the [Spanish] Crown". ["Es cierto, la única actividad regulada por las Ordenanzas era la judicial. Pero el resto fue impuesto al gremio por la conveniencia, por la costumbre y por los contratos establecidos con la Corona"]. Id. at 619 (emphasis in original) (translation by author).

50 “[F] avorecer la creación de un tribunal en que se determinen según estilo de mercaderes, sin dar lugar a pleitos y dilaciones, todas las diferencias y debates entre los mercaderes 
fected merchants and the persons who dealt with them. ${ }^{51}$ Nevertheless, Consulates had no jurisdiction over disputes that were unrelated to shipped or stored merchandise. ${ }^{52}$

The Spanish Ordenanzas always played an important role in Mexico. ${ }^{53}$ The Ordenanzas of Seville and Burgos were the basis for the Ordenanzas of the Consulate of Mexico, ${ }^{54}$ and the Ordenanzas of Bilbao regulated commerce in Mexico until the enactment of the Commercial Code of 1884. ${ }^{55}$ Moreover, the manner in which Ordenanzas were enacted illustrates the influence that merchants had over the legal drafting process.

In contrast to the Ordenanzas of Burgos and Seville, the document that established the Consulate in Mexico had no provisions concerning the creation of its own Ordenanzas. ${ }^{56}$ Merchants in Mexico City requested that the monarch grant them the authority to write their own Ordenanzas. ${ }^{57}$ In 1594, King Felipe III authorized the Universidad to create Ordenanzas for Mexico and to use the Ordenanzas from Seville for two years while the Mexican ones were being drafted. ${ }^{58}$

Nonetheless, it seems that the Ordenanzas of Mexico were not as influential as those from Seville, Burgos and Bilbao. ${ }^{59}$ Barrera Graf indicates that the Ordenanzas from Burgos were applied as secondary law in the Americas while those from Seville "became Book IX of the Leyes de Indias, which were applied as the principal law" in the Americas. ${ }^{60}$ Nonetheless, the most influential ones were the Ordenanzas from Bilbao, which governed Mexican commercial transactions until the enactment of the Commercial Code of $1884{ }^{61}$

de estas provincias". Ruiz Guerra supra note 36 at 623 (quoting other author) (translation by author). Nevertheless, the Spanish Crown had to approve the creation of Ordenanzas and to also determine the jurisdiction of the Consulates. See Ana María Barrero García, Las Ordenanzas de los Consulados Castellanos e Indianos (Siglos XVI-XVII), Su Estudio Comparativo, 14 Revista ChiLEna DE Historia Del Derecho, 1991, at 53, 53-58 http://www.historiadelderecho.uchile.cl/index.php/ RCHD/article/view/24794.

51 The Viceroy decided jurisdictional conflicts between merchants and non-merchants. Ruiz Guerra supra note 36 at 624.

52 Id. Consulates worked as more than mere tribunals. They also regulated commercial factors, organized merchant activities (such as parties, masses, etc.), ran merchant meetings to solve important issues in emergency situations, and coordinated the recovery of sunken ships and the subsequent division of the spoils among members of the guild. $I d$. at 624,625 .

53 See Barrero García, supra note 50.

54 See id. at 61, 62.

55 Barrera Graf, supra note 39 at 120-121.

56 Barrero García, supra note 50 at 58.

57 Id. at 58 .

58 Id. The Mexican Ordenanzas were enacted on October 20, 1604. Id.

59 See Barrera Graf, supra note 39 at 119-121.

60 "Se convirtieron en el libro IX de las Leyes de Indias, las cuales sí se aplicaron como derecho principal en América." Id. at 120 (translation by author) (quoting another source).

61 Id. at 120-121. 
As with the Ordenanzas of Seville, Burgos, and Mexico, the Ordenanzas of Bilbao were the creation of the merchants themselves. ${ }^{62}$ In September 1735 the General Commerce Committee of Bilbao decided to name "six people among the merchants of the town, the smartest and most pragmatic, and with the best reputation". ${ }^{63}$

Professor Gorordo ${ }^{64}$ explains that the merchants of Bilbao had always ruled commercial law in their geographical area. ${ }^{65}$ At first, they used the Ordenanzas from Seville, but decided to request permission to create their own due to "the changes of the times, and new cases" 66 that required more precise and clearer orders. ${ }^{67}$ The Ordenanzas of Bilbao were enacted in $1737.68 \mathrm{Al}$ though enacted in Spain, due to the chaotic situation experienced by Mexico during the 19th century, merchants in Mexico relied on the Ordenanzas of Bilbao, among other laws, to regulate their affairs. ${ }^{69}$

62 José María Gorordo, Las Ordenanzas de Bilbao de 1737, la Real Compañía Guipuzcoana de Caracas, Ejemplos de "Derechos Históricos", ni Amparados ni Respetados, BLOG DE José María Gorordo (Apr. 28, 2010), https://josemarigorordo.wordpress.com/2010/04/28/las-ordenanzas-de-bilbao-de-1737-ejemplo-de-derechos-historicos-ni-amparados-ni-respetados/. See also Barrero García, supra note 50 at 53-58.

63 “[S] eis personas de los Comerciantes de la Villa, los más prácticos e inteligentes y los de mejor concepto". Gorordo, Las Ordenanzas de Bilbao de 1737, supra note 62 (quoting another source) (translation by author) (emphasis added). More about the history of the Ordenanzas, see Las Ordenanzas del Consulado de Bilbao, Tres Conferencias con motivo del CentenaRio de su Derogación (Academia de Derecho y Ciencias Sociales de Bilbao, eds., 1931).

64 Spanish author, Doctor in Law from the University of the Basque Country. José María Gorordo, Acerca del Autor, Blog DE José María Gorordo, https://josemarigorordo.wordpress.com/ about/.

65 Gorordo, Las Ordenanzas de Bilbao de 1737, supra note 62.

66 "La mutación de los tiempos y nueva ocurrencia de casos" id. (quoting another source) (translation by author).

67 Id.

68 Id. See also Ordenanzas de la Ilustre Universidad y Casa de Contratación de la M.N. y M.L. Villa de Bilbao [Ordenanzas of Bilbao] (1737 and 1814), as amended in 1818 (Spain).

69 See "The political struggle to decide the course and characteristics of the young country, with the constant change of governments of contrary ideology and policy, made the survival of Spanish commercial laws possible. Thus, the Partidas, the Ordenanzas of Bilbao and even the Spanish Commercial Code of 1829 continued to be applied instead of national laws, which were only in force for a few years". ["La contienda política por decidir el rumbo y las características que había de tener el joven país, con la consecuente alternancia de gobiernos de signo y políticas contrarios, hizo posible la supervivencia de los ordenamientos españoles en la aplicación del derecho mercantil. Así, frente a los ordenamientos nacionales, los cuales sólo estaban vigentes por pocos años, se siguieron aplicando las Partidas, las Ordenanzas de Bilbao e incluso el Código de Comercio español de 1829”]. María del Refugio González supra note 37 at 133 (internal citations omitted) (translation by author).

In the $19^{\text {th }}$ century Mexico had internal conflicts and wars against France and the U.S., among others. See Miguel Ángel Segundo Guzmán, México en el Siglo XIX, de Centenarios y Bicentenarios, PaCarina del Sur, Nov. 14, 2014, http://wrwre.pacarinadelsur.com/home/huellas-yvoces/156-mexico-en-el-siglo-xix-de-centenarios-y-bicentenarios. 
After the war of Independence, Consulates were abolished by a decree order on October 16, 1824, and jurisdiction over commercial matters was given to city mayors and judges. ${ }^{70}$ Spanish law, including the Spanish Commercial Code of 1829, was applied as secondary law. ${ }^{71}$

On November 15, 1841, Mexican president General Antonio Lopez de Santa Anna issued a decree regarding the organization of commerce courts. ${ }^{72}$ Barrera Graf regards this as the first real Mexican Commercial Code. ${ }^{73}$ The decree mentioned merchants - both individuals and business associationsand required licensing in order to partake in commerce. However, it also included a list of "businesses" that were deemed commercial. ${ }^{74}$ In addition, the decree ordered that the Ordenanzas of Bilbao were to be used while a new Commercial Code was drafted. ${ }^{75}$

Mexico's first Commercial Code was enacted in May 1854. ${ }^{76}$ This Code is also known as the "Lares Code", in honor of one of Mexico's most renowned commercial law scholars who drafted it. ${ }^{77}$ This code covered a large number of commercial contracts, promises and obligations; ${ }^{78}$ it was based on the French Code de Commerce of 1807 and the Spanish Commercial Code of 1829, while including a list of "businesses" that were regarded as commercial in nature. ${ }^{79}$ The applicability of this code was not clear, however, and as with many other laws and regulations of the time, its application depended on who wielded enough political and military power to enforce it. ${ }^{80}$

An 1855 decree granted jurisdiction to lay, or non-merchant, civil judges to adjudicate commercial cases. ${ }^{81}$ In April 1884, a Commercial Code was enacted $^{82}$ to regulate "acts of commerce" ("actos de comercio") as opposed to the previous "businesses". It also oversaw business organizations and intellectual property. ${ }^{83}$

\footnotetext{
70 Barrera Graf, supra note 39 at 128.

71 Id. at 130 .

$72 I d$. at 133.

$73 I d$. at 133

74 Barrera Graf indicates that the French Code of 1807 influenced this decree. Id. at 133.

75 Id. at 133-134.

76 The code was enacted in the last year of Santa Anna's government. Id. at 137-138.

77 The legal scholar's name was Teodoro Lares. Id. at 138.

78 That is, commerce on land, commerce on sea, bankruptcies, and commercial procedures. Id. at 138 .

79 "[C] ontenía una lista de negocios que la ley reputaba como mercantiles..." [It had a list of businesses that the law regarded as commercial in nature.] $I d$. (translation by author).

80 See id. at 139. Also supra note 69.

81 Interim president Juan Alvarez, who defeated Santa Anna, enacted this decree. Barrera Graf, supra note 39 at 139.

82 Id. at 141 .

83 Id. at 141-142.
} 
It should be mentioned that a Constitutional reform was required for the enactment of this code because the then in force Constitution of 1857 gave no power to the Mexican Congress to enact a Commercial Code. ${ }^{84}$ Article $72(\mathrm{X})$ of the Constitution of 1857 only indicated that, "Congress has the power... [t] o establish the general basis of commercial legislation". ${ }^{85}$ In December 1883, the article was reformed in order to authorize Congress to enact "mandatory Codes for Mining and Commerce throughout the Republic...". 86

The fact of this Constitutional reform is not as important as the reasons given for it. The original version of Article $72(\mathrm{X})$ could be read as granting Congress the power of creating general rules that would be complemented with commerce customs, similar to the system in force with the Ordenanzas of Bilbao. ${ }^{87}$ Nonetheless, it seems that legislators interpreted said article differently.

In his study of the history of Mexican commercial law, Enrique Orozco ${ }^{88}$ transcribes a document from the commission charged with drafting a commercial code in $1870 .{ }^{89}$ In it, the commission explains that during the creation of the French Code de Commerce of 1807, Napoleon opposed the creation of generic commercial rules and instead proposed enacting "general principles", 90 allowing the possibility for them to be implemented later by passing specific rules. This proposal was later discarded as the idea of breaking up commercial law into several parts — rather than having a single Code - was seen as

84 See Enrique Orozco, La Evolución de la Legislación Mercantil en la República desde la Proclamación de la Independencia Nacional hasta Nuestros Días, in Diario de Jurisprudencia del Distrito y Territorios Federales, tomo XXIII, 104, 111 (Victoriano Pimentel ed., May, June, July and Aug. 1911) (the first part of the study appears on Tomo XXII). See also Raul Iturralde Gonzalez, The Need to Remove the Civil Code from the Mexican Commercial Lawes, The Case of Offers and Firm Promises, 10 Mex. L. Rev. 21, 26-27 (2017).

85 "El Congreso tiene la Facultad ...X. Para establecer las bases generales de la legislación mercantil" Constitución Política de la República Mexicana sobre la indestructible base de su legítima independencia, proclamada el 16 de septiembre de 1810, y consumada el 27 de septiembre de 1821 [G.P. 1857], Art. 72(X), http://wrew.juridicas.unam.mx/infjur/leg/conshist/ $p d f / 1857 . p d f$ (translation by author).

86 Orozco supra note 84 at 111.

87 See infra "The archetypal merchant in the Ordenanzas of Bilbao". Analysis by Orozco supra note 84 at 96.

88 Enrique Orozco was commissioned by the Academia Central Mexicana de furisprudencia y Legislación to write a research paper on the history of Mexican commerce law from independence to 1911. Diario de Jurisprudencia del Distrito y Territorios Federales, Tomo XXII, 645 (Victoriano Pimentel ed., Jan., Feb., March and Apr. 1911), see also supra note 84.

89 Orozco, supra note 84 at 102-103.

90 “[P] roponiendo al cuerpo legislativo principios generales, á reserva de desarrollarlos después por vía de reglamento...", letter [Exposición de Motivos] from the Drafting Commission to the Minister of Justice (Jan. 4, 1870) in id. at 102 (translation by author). 
too difficult. ${ }^{91}$ The importance of the history of the French Code de Commerce will be apparent later.

Nonetheless, it is important to note that the commercial code drafters had reservations about the creation of a commercial code that established general principles that would later be complemented either by legislation (only federal or a combination of federal and state law) or by custom. As evidence of the issues arising from not having a comprehensive and detailed uniform commerce law, the drafters provided the following quote from Juan Antonio de la Fuente ${ }^{92}$ on the enactment of a law regulating commercial agents:

Treaties had established only the foundations [for a law regulating commercial agents] and some of their powers and prerogatives [or privileges]; whereas our laws... increasingly became an object of doubt and confusion. True, our customs and the authoritative judgments of our courts could have filled such a void; however, more than time, what we lacked was peace, in whose shadow our customary law would have been created and taken hold. Even what was written, limited as it was, has not been faithfully upheld, and only the revolutions that have shaken the country can explain how this essentially practical matter [customary law], which has been much discussed and so fruitful in obtaining far-reaching results, has been... abandoned to chance by an uncertain and unusual law. ${ }^{93}$

The 1870 drafting commission then continues with arguments against allowing states to regulate commerce. ${ }^{94}$ Orozco's work illustrates some of the

$91 \quad I d$.

92 Orozco does not give much information regarding Juan Antonio de la Fuente. It appears that Orozco is referring to Juan Antonio de la Fuente, a former Secretary of State. See Jorge Pedraza Salinas, Bicentenario de Juan Antonio de la Fuente, REGIO.COM (June 19, 2014), http://elregio.com/editoriales/cuestion-de-tiempo/93849-bicentenario-de-juan-antonio-de-la-fuente.html.

93 "Los tratados habían establecido solamente sus bases, y alguna de sus atribuciones y prerrogativas; mientras que nuestras leyes... venían a ser un elemento más de dudas y confusión. Verdaderamente nuestras costumbres y las autorizadas sentencias de nuestros tribunales hubieran podido llenar semejante vacío; pero más que el tiempo, nos ha hecho falta la paz, a cuya sombra hubiera nacido y cobrado vigor nuestro derecho consuetudinario. Aún el escrito, tan limitado como era, no ha sido fielmente guardado, y solamente las revoluciones que han agitado el país pueden explicar cómo esta materia, esencialmente práctica, tan debatida y fecunda en resultados trascendentales, ha sido... abandonada a la ventura, por un derecho incierto e inusitado". Letter from Juan Antonio de la Fuente to the Governors of the States (1858) in Orozco supra note 84 at 103 (translated by Mina Goldberg).

94 "It is easy to understand that, for its development, commerce needs a law that is consistent throughout the Republic". ["Fácil es comprender que el comercio necesita, para su desarrollo, una ley que sea uniforme en toda la República"]. letter [Exposición de Motivos] from the Drafting Commission to the Minister of Justice (Jan. 4, 1870) in Orozco supra note 84 at 104 (translated by author) (I assume that this was part of the letter, nevertheless, due to the manner in which the study is presented, it is difficult to determine whether this was, instead, written by Enrique Orozco.) 
motivations driving the Commercial Code drafters. ${ }^{95}$ While prompted by a distrust of any form of independent creation of commerce laws, they were also strongly influenced by the French Code de Commerce and French legal doctrine. ${ }^{96}$

A brief clarification is needed here as to the reasons behind the enactment of two commercial codes in such brief period of time. Quoting other authors, Prof. Astudillo Ursua presents some reasons underlying the sudden reform as the difficulties that the 1884 code created for regulating banks and business organizations, particularly the Sociedad Anónima. ${ }^{97}$ Even though there were attempts to save the 1884 code with the enactment of regulatory laws and possible reforms, a new code was passed instead. ${ }^{98}$

As will be seen later, the archetypal merchants in the Ordenanzas and in the Commercial Code of 1889 are completely different. This change can be explained, in part, as the result of legislators' wariness in leaving the law governing commerce to be established by anyone other than the federal government (a situation that would include mistrust of the use of custom as a tool to create the law). The change can also be seen as a reaction against the guild system and the use of merchant courts promoted by the Ordenanzas of Bilbao. ${ }^{99}$

\section{The Archetypal Merchant in Mexico Before the Commercial Code of 1889}

\section{The Archetypal Merchant in the Ordenanzas of Bilbao}

As indicated above, the Ordenanzas of Bilbao were the de facto commercial legislation in Mexico until the appearance of the Commercial Code of 1884. ${ }^{100}$

95 See Iturralde supra note 84 at 26-27.

96 See supra notes 89-91 and accompanying text (the commission tasked with drafting a commercial code in 1870 reviewed the history of the French Code de Commerce). Also, the French Code de Commerce of 1807 and the Italian Commercial Code of 1882 were used as models for the Mexican Commercial Code. Barrera Graf, supra note 39 at 111 . See also Jorge Barrera Graf, Derecho Mercantil 7-8 (UNAM 1991), http://biblio.juridicas.unam.mx/libros/libro.htm?l=276.

97 Pedro Astudillo Ursua, Hace cien años el Código de Comercio de 1989, commemorative number 1991 Revista de la Facultad de Derecho de México [RFDM] 151, 154-156 (Prof. Astudillo quotes Jacinto Pallares, Felipe de J. Tena, and the Ministerio de Justicia e Instrucción Pública), http://historico.juridicas.unam.mx/publica/rev/indice.htm ${ }^{2} r=$ facdermx $\mathcal{E}^{2} n=175.5$. See also one of the quoted texts appears on the study by Enrique Orozco. Orozco supra note 84 at 111-112.

98 See Astudillo, supra note 97 at 154-156.

99 See supra notes 48-52 and accompanying text.

100 See supra notes 55, 69 and 82 and accompanying text. At various points in time, the Ordenanzas of Bilbao were the official law of Mexico. For an example of a court using the Ordenanzas of Bilbao, see "[t] he same Ordenanzas [of Bilbao], applicable as per the Judicial Notice of September 29, 1856...". ["Las mismas Ordenanzas, que son las aplicables segun la circular 
It will become clear that the archetypal merchant of the Ordenanzas was completely different from the archetypal merchant used in the current Commercial Code.

As a form of self-regulation, merchants are expected to craft an archetype on the basis of how a good merchant is expected to behave. One sound means of determining how legislators regarded the archetypal regulated individual is to see how much trust they put on them by determining how they demonstrated their "good faith". ${ }^{101}$

The Ordenanzas mention the use of "good faith" to solve commercial disputes at least ten times. ${ }^{102}$ They start by indicating that Consulates have to resolve commercial matters in a brief and expeditious manner by relying, on the basis of merchant customs, on the truth that is brought to light and the good faith of the parties involved. ${ }^{103}$ The next article repeats this by indicating which disputes heard by the Consulates are to be decided in a brief and timely manner using the truth known and the good faith of the parties involved. ${ }^{104}$ Note the willingness of this provision to allow merchants to testify on their own behalf and according to their own rules, something that $19^{\text {th }}$ century commercial procedure codes only allowed when subject to formal "confessional" procedures. ${ }^{105}$

de Justicia de 29 de Setiembre de 1856..."] Benecke v. Zubieta, in Anuario de legislación y Jurisprudencia, año I, Sección de Casación, Collección Completa de las Ejecutorias Pronunciadas por la Primera Sala del Tribunal Superior de Justicia del Distrito Federal, 1884, page 35 (Pablo Macedo \& Miguel S. Macedo eds.) (translation by author). See also infra Section 2 Examples of archetypal merchants...

101 Dr. Kozolchyk explains the importance of good faith: "[T] he overarching principles of honesty, reasonableness and fair dealing... are the «nuclear» components of good faith. At times they are found in statutory law, at times in case law and doctrinal writings, but most frequently they are imbedded in standard and best practices". KozolchyK, Comparative supra note 3 at 951. See also supra note 34 and accompanying text.

102 Ordenanzas de la Ilustre Universidad y Casa de Contratación de la M.N. y M.L. Villa de Bilbao [Ordenanzas of Bilbao] Ch. 1, Arts. 6, 7, 16, Ch. 5, Art. 12, Ch. 10, Arts. 2, 3, Ch. 13, Art. 21, Ch. 17, Art. 4, 54, Ch. 19, Art. 1 (1737 and 1814), as amended in 1818 (Spain).

103 "Por cuanto en dicho Consulado deben determinarse los pleitos y diferencias de entre las partes breve y sumariamente, la verdad sabida y la buena fe guardada por estilo de mercaderes". [Lawsuits and disputes have to be resolved expeditiously and summarily in said Consulate with the truth known and good faith according to merchant customs.] Ordenanzas of Bilbao at Ch. 1, art. 6 (translation by author).

104 "Atendiendo a los fines arriba expresados, de que en los pleitos y diferencias se haga justicia breve y sumariamente, y solo sabida la verdad, y guardada la buena fe". [In light of the objectives mentioned above, lawsuits and disputes must be resolved expeditiously and summarily relying only the truth known and good faith.] Ordenanzas of Bilbao at Ch. 1, art. 7 (translation by author). Good faith is considered not only in the first instance, but also in appeals. Ordenanzas of Bilbao at Ch. 1, Art. 16.

105 Kozolchyк, Comparative supra note 3 at 171-174. 
The principle of good faith is again used when the Ordenanzas regulate the creation and operation of business organizations. ${ }^{106}$ The Ordenanzas direct merchants to act in good faith in their interaction with other members of any type of business organization. ${ }^{107}$ Good faith is required not only from merchants who are members of business associations, but also in the payment of bills of exchange. ${ }^{108}$ The article regarding bills of exchange indicates that "...it is in accordance with good faith in commerce that the payment of bills of exchange must be done efficiently and promptly". ${ }^{109}$ This in itself is indicative of a different archetypal merchant: he did not seem to be suspected, as was his French counterpart, of the sin of usury by using a bill of exchange to hide or mask the payment of interest as a "commission for the sale of exchange" (cambium). ${ }^{110}$

The good faith and trustworthiness of the merchant are also considered in cases of bankruptcies, which are regulated in Chapter 17. This chapter begins by stating that not all merchants that fail to pay their debts should be treated in the same way, as some are delinquent due to force majeure and others due to malice. ${ }^{111}$ Therefore, the Ordenanzas divide bankrupt merchants into three categories:

1) Those who are delinquent on their payments due to oversight; ${ }^{112}$

106 Ordenanzas of Bilbao at Ch. 10.

107 "En cualesquiera géneros de compañías deberán proceder de buena fe los comerciantes en la parte que se obligaren hacia los demás compañeros...”. Ordenanzas of Bilbao at Ch. 10, Art. 2.

108 Ordenanzas de la Ilustre Universidad y Casa de Contratación de la M.N. y M.L. Villa de Bilbao [Ordenanzas of Bilbao] Ch. 13, Art. 21 (1737 and 1814), as amended in 1818 (Spain).

109 “...conviene á la buena fe del comercio la eficacia y puntualidad con que deben hacerse las pagas de las letras de cambios". Ordenanzas of Bilbao at Ch. 13, Art. 21 (emphasis added) (translation by Mina Goldberg).

"It should be noted that more than two centuries later, Mexico's article 139 of its securities law still requires the holder of a bill of exchange to formally «protest» its lack of acceptance or payment except when the drawer or endorser waives such a procedure". Letter from Boris Kozolchyk to Raul Iturralde Gonzalez (Dec. 11, 2017) (on file with author). Ley General de Títulos y Operaciones de Crédito [L.G.T.O.G.] [General Law of Negotiable Instruments and Credit Operations] as amended, Art. 139, Diario Oficial de la Federación [D.O.] August 27, 1932 (Mex.).

110 See the analysis made by Dr. Kozolchyk on the rejection of Napoleon Bonaparte on laymen getting involved in credit transactions. Kozolchyк, Comparative supra note 3 at 328-29. Also see his analysis on the sin of usury. Id. at 150-151.

111 "Respecto de que por la desgracia de los tiempos y [sic] infelicidad a malicia de algunos negociantes se experimentan muchas veces atrasos, falencias a quiebras ..." [Due to the misfortune of the times and the malice of some merchants there are sometimes delays, fraud or bankruptcies...] Ordenanzas of Bilbao at Ch. 17, Art. 1 (translation by author).

112 Ordenanzas of Bilbao at Ch. 17, Art. 2. 
2) Those who are delinquent due to force majeure; ${ }^{113}$ and

3) Those who fail to pay their debts due to fraud. ${ }^{114}$

The Ordenanzas state that merchants who are delinquent due to oversight will preserve their good credit, good name and reputation as long as they have enough assets to cover their debts. ${ }^{115}$ Those who have had to deal with

113 Ordenanzas de la Ilustre Universidad y Casa de Contratación de la M.N. y M.L. Villa de Bilbao [Ordenanzas of Bilbao] Ch. 17, Art. 3 (1737 and 1814), as amended in 1818 (Spain).

114 Ordenanzas of Bilbao at Ch. 17, Art. 4. Contrast this with the treatment of bankruptcy in the Napoleonic Code de Comerce:

"Bankruptcy (faillite) was defined as the state of having stopped payments (cessation de paiements), but the procedure was started only by a judgment stating that a person or a company (sociétê) was in that situation... The bankrupt was supposed to be jailed, and the judge to name a trustee (syndic) responsible for the management of the [assets and liabilities and the overall] procedure in the interests of the creditors; this supposed either finding a composition (concordat), an agreement with the creditors allowing the perpetuation of the firm (which usually included a reduction and a new schedule for the debts), or organizing the complete liquidation of the debtor's estate (union)". Pierre-Cyrille Hautcoeur \& Nadine Levratto, Legal versus Economic Explanations on the Rise in Bankruptcies in $19^{\text {th }}$ Century France 4 (Paris School of Economics, Working Paper No. 47, 2007) http://werere.parisschoolofeconomics.eu/docs/hautcoeur-pierre-cyrille/wp200747. pdf in Kozolchyк, Comparative supra note 3 at 330.

Also "Established under an authoritarian government aiming at stabilizing a society much affected by the revolutionary years, and especially at re-establishing traditional authorities and property based wealth at the top of society, the 1807 code was considered as excessively severe and inefficient by many contemporaries and the courts themselves, and has been considered so by the historiography. It had an excessive recourse to jail, made difficult reaching a concordat, and the procedure was excessively slow and costly. It was probably efficient in making bankruptcy a threat to all traders, but not in protecting the interests of the creditors, and even less so in allowing unlucky traders having a fresh start, since, except under a concordat, all assets they could accumulate later could always be seized under their bankruptcy case, and they remained marked with the infamous seal of bankruptcy (and deprived of all political and some civil rights) until a very unlikely rehabilitation which supposed a complete reimbursement of all debts with interest. Then, debtors facing payment difficulties tried to avoid the courts by settling their case privately with their creditors, something which frequently led to inequalities among creditors or even fraud, sometime also to belated recourses to the courts with chaotic consequences". Hautcoeur \& Levratto, supra at 4-5 (original citation omitted) (emphasis added, cursives in original).

115 "La primera clase ó genero de comerciantes que no pagan lo que deben á su debido tiempo, se deberá reputar por atraso, teniendo aquel ó aquellos á quienes suceda bastantes bienes para pagar enteramente á sus acreedores, y si se justificare que por accidente no se halla en disposición de poderlo hacer con puntualidad, haciéndolo después con espera de breve tiempo, ya sea con intereses ó sin ellos, según convenio de sus acreedores. A semejantes se les ha de guardar el honor de su crédito, buena opinión y fama". [The first class or type of merchants who do not pay their debts on time must be regarded as merely in arrears, as long as they have enough assets to pay their creditors, and if their inability to pay on time is justified by force majeure, they must pay shortly thereafter (either with or without interest as per agreement with their creditors). These merchants may retain their good credit, good name and reputation]. Ordenanzas of Bilbao at Ch. 17, Art. 2 (translation by author). 
incidents of force majeure like a shipwreck or a robbery while transporting their merchandise by land shall be considered bankrupt without fault as long as they have reached an agreement with their creditors to reduce their debt. However, they would not have a voice in the Consulate until they paid such debts. ${ }^{116}$

As we can see, the Ordenanzas showed leniency towards merchants' inability to pay their debts. While Articles 2 and 3 deal with situations wherein merchants have acted without malice and their ability to pay their debts in a timely manner has been negatively impacted either by inadvertent oversight or force majeure, Article 4 of Chapter 17 provides that merchants who act with fraudulent intent shall be "regarded as vile public thieves, robbers of the assets of others, and shall be persecuted until [Consulate officers] capture them...". 117 Once captured, the Ordenanzas stipulate that these fraudulent merchants shall be delivered to civil authorities so they may be tried in criminal court, ${ }^{118}$ as Consulates had exclusive jurisdiction over commercial matters, but not over criminal cases. ${ }^{119}$

Regarding the issue of jurisdiction and procedure, it is important to remember that merchants drafted their laws and regulated their courts (the Consulates). ${ }^{120}$ The Ordenanzas stipulate that judicial procedure has to be followed orally and without many formalities, ${ }^{121}$ while making clear that disputes should be resolved without the need for "lawyers' writings." 122

Further, it is evident that the Ordenanzas took the exclusive jurisdiction of the Consulates seriously, as is apparent in a set of orders issued by the Spanish monarch prohibiting civil courts from hearing disputes that fall within the exclusive jurisdiction of the Consulates. ${ }^{123}$

Hence, it is apparent that the image of the merchant archetype in the Ordenanzas is that of a trustworthy merchant. The Ordenanzas rely on the good faith of the merchants and presume that they act in good faith, such as in bankruptcy cases. Although, this is expected from a "code" drafted by the same merchants whose actions it regulates.

116 Ordenanzas of Bilbao at Ch. 17, Art. 3.

117 "[S]e les ha de tener y estimar como infames ladrones públicos, robadores de hacienda agena, y se les perseguirá hasta tanto que el Prior y Cónsules puedan haber sus personas..." Ordenanzas of Bilbao at Ch. 17, Art. 4 (translation by author).

118 Ordenanzas of Bilbao at Ch. 17, Art. 4.

119 Ordenanzas de la Ilustre Universidad y Casa de Contratación de la M.N. y M.L. Villa de Bilbao [Ordenanzas of Bilbao] Ch. 1, Art. 2 (1737 and 1814), as amended in 1818 (Spain).

120 See supra notes 47 and 48 and accompanying text.

121 Ordenanzas of Bilbao Ch. 1, Arts. 6, and 7.

122 "In the Consulates, issues and disputes have to be resolved... without delay, legal writings or lawyers' writings...". Ordenanzas of Bilbao at Ch. 1, Art. 6 (translation by author).

123 Royal decree, Oct. 1, 1816 (Archive of Bilbao's Consulate) in Ordenanzas of Bilbao supra note 102 at 348-349. 


\section{Examples of Archetypical Merchants Used in Cases before the Enactment of the Commercial Code of 1889}

The influence of the Ordenanzas of Bilbao and the principles expressed therein can be appreciated in the reports of some decisions handed down in Mexico even after the appearance of the Commercial Code of $1884 .{ }^{124}$ One example is the decision in the case of García Torrez v. Bocker $E^{2}$ Co., ${ }^{125}$ which was decided by the Cassation Chamber of the Superior Justice Court of the Federal District. ${ }^{126}$

The Public Ministry argued: ${ }^{127}$

It is the judgment of the undersigned that it cannot be said that the judicial decision presently being appealed is contrary to the letter or the spirit of [Article 830 of the Commercial Code of 1884], since the judge in his decision presents it as just one example of commerce law accepting the commercial custom of good faith as a basis for commercial transactions, indispensable for expediting transactions, while not undermining the advantages that this principle offers. ${ }^{128}$

The case of Garcia Torres v. Bocker $\mathcal{E}^{2}$ Co. mentioned above referred to a bill of exchange that was given to Mr. García Torres by an endorser of the bill. ${ }^{129}$ The convoluted description of the facts explains that the bill was originally

124 The cases presented here belong to the reported cases of the Cassation Chamber of the Superior Justice Court of the Federal District from 1884 to 1897, http://catalog.hathitrust.org/ Record $/ 010428106$ ?type $\% 5 B \% 5 D=$ subject Elookfor $\% 5 B \% 5 D=\% 22 \% 20$ Law $\% 2$ reports $\% 2 C \% 20$ digests $\% 2 C \% 20$ etc. $\% 20$ Mexico. $\% 22$ Eft $=$.

125 García Torres v. Becker E̊ Co., in Anuario de legislación y Jurisprudencia [Anuario (1888)], año V, Sección de Casación, Collección Completa de las Ejecutorias Pronunciadas por la Primera Sala del Tribunal Superior de Justicia del Distrito Federal, 98 (Mex.) (Pablo Macedo \& Miguel S. Macedo eds., 1888). See also Iturralde supra note 84 at 24-25.

126 Cassation was an appeal based on irregularities in the application of the law. Julio Bustillos, Surgimiento y Decadencia de la Casación en México, 3 Reforma Judicial, Revista Mexicana de Justicia January-June 2004, at 141, 147, http://biblio.juridicas.unam.mx/revista/ Reformafudicial/indice.htm? $n=3$. For more information on the history of cassation in Mexico and its replacement by the amparo procedure see id.

127 The transcripts of the decisions in the Anuarios include the transcript of the arguments presented by the parties. In this case, the arguments presented are those of the Public Ministry and the defendant.

128 "A juicio del suscrito no puede decirse que la decisión judicial materia de este recurso, haya sido contraria á la letra ó espíritu de [el art. 830 del Código de Comercio de 1884], pues el juez en su sentencia lo presenta solamente como un ejemplo de que la ley ha sancionado la costumbre mercantil de prestar como base á las operaciones de comercio la buena fe, indispensable para la rapidez de las transacciones, y de no destruir las ventajas que trae este principio". García Torres vs. Bocker E Co., in Anuario (1888) supra note 125 at 100 (emphasis added) (translation by author). See also Iturralde supra note 84 at 24-25.

129 García Torres vs. Bocker \& Co., in Anuario (1888) supra note 125 at 99. 
paid the same day that it was endorsed to Mr. García Torres. ${ }^{130}$ Mr. García Torres later attempted to collect payment for his bill of exchange, which was actually a duplicate. ${ }^{131}$ It seems that the confusion and the basis of the claim rests on the fact that the bill was paid to a dependent of Mr. García Torres, who had received payments in lieu of Mr. García Torres before and who appeared with the bill sealed and signed by Mr. García Torres. ${ }^{132}$ From the pleadings by the Public Ministry, it is possible to deduce that the dependent cashed the bill of exchange without notifying Mr. García Torres, after which the dependent disappeared with the money. ${ }^{133}$ The appealed decision found that the payment was valid and that Bocker \& Co. was not liable. ${ }^{134}$

The Court of Cassation decided against the appellant. ${ }^{135}$ In reviewing the case, the court interprets the Commercial Code strictly, without mentioning anything about the application of good faith or commercial customs which the Public Ministry argued in favor of doing.

Another example of the use of good faith and the principles found in the Ordenanzas can be seen in the decision of In re Successors of Agustin Meeser, which was a review of a decision issued in a bankruptcy case. ${ }^{136}$ The trustee in bankruptcy brought the appeal before the court of Cassation. ${ }^{137}$ The issues in the case related to the trustee's power to file an appeal and define the order in which creditors should be paid. ${ }^{138}$

Putting aside the main issues of the case, it is important for the purposes of this article to note that the Public Ministry argued the following:

Much has been said during the debates about how unheard of it is to suppress the privilege given to credits that appear in a simple deed; nonetheless, what is certain is that, given the nature of the business of commerce, which is based on good faith and pure equity rather than on formal requirements, there is nothing surprising regarding said suppression, which existed in ancient laws. ${ }^{139}$

\footnotetext{
130 García Torres vs. Bocker $\mathbb{S}^{2}$ Co., in $i d$. at 104.

131 García Torres vs. Bocker $\mathcal{E}^{2}$ Co., in id.

132 García Torres vs. Bocker $\mathcal{E}^{2}$ Co., in id. at 99.

133 García Torres vs. Bocker E Co., in id. at 99.

134 García Torres vs. Bocker E Co., in id. at 99-100.

135 García Torres vs. Bocker $\mathcal{F}^{\circ}$ Co., in id. at 112.

136 In re Successors of Agustín Meeser, in Anuario (1888) supra note 125 at 476. See also Iturralde supra note 84 at 25-26.

137 In re Successors of Agustin Meeser, in Anuario (1888) supra note 125 at 476-477.

138 In re Successors of Agustín Meeser, in $i d$. at 495-496.

139 "Mucho se ha dicho durante los debates acerca de lo inaudito de la supresión del privilegio en favor de los créditos escriturados simples; pero lo cierto es, que dada la naturaleza de los negocios mercantiles, fundados más que en requisitos de forma, en la buena fe y la más pura equidad, nada tiene de sorprendente esa supresión, la cual, por otra parte existió en las leyes antiguas". In re Successors of Agustín Meeser, in id. at 487 (emphasis added) (citing another source) (translation by author).
} 
The court issued its decision declaring that the cassation appeal was legally submitted and that the credit in dispute had to be paid pro rata. ${ }^{140}$ As with the previous decision, the court decided on the basis of a strict interpretation of the Commercial Code. The court did not discuss the issue of good faith the Public Ministry raised in its argument.

These cases provide a window through which to view commerce law during the transition from the use of the Ordenanzas, and their trustworthy archetypal merchant, to the use of the Commercial Code, which did not share such a view, as will be seen later. These cases show that the litigants still saw the use of good faith and customs as tools to resolve commercial disputes, while judges had begun to rely on a strict interpretation and application of the Commercial Code. ${ }^{141}$

\section{The Archetypal Merchant in the Mexican Commercial Code of 1889}

\section{The Influence of French Doctrine}

It would seem strange to start talking about French legal doctrine in a discussion that has centered on the Mexican Commercial Code and the Ordenanzas of Bilbao. Nonetheless, the fact is that French commercial law doctrine and the French Code de Commerce of 1807 heavily influenced the Commercial Code. ${ }^{142}$ The French Code de Commerce promoted an objective approach to commercial regulation ${ }^{143}$ which the Commercial Code of 1889 adopted. ${ }^{144}$

140 In re Successors of Agustín Meeser, in Anuario, supra note 125 at 501.

141 The view of judges regarding this strict application of the commercial code is not clear from the case law and it goes beyond the scope of this article.

142 See supra note 96 and accompanying text. Also see the adoption of the objective approach to commercial regulation that appeared in the French Code de Commerce of 1807, which influenced the development of commercial legislation in Mexico. María del Refugio González, supra note 37 at 134, 147. Also compare Código de Comercio [CoD. Com. 1889] [Commercial Code 1889], 75, Diario Oficial del Supremo Gobierno de los Estados Unidos Mexicanos [now Diario Oficial de la Federación], October 7-December 13, 1889 (Mex.), http://wrwr.diputados. gob.mx/LeyesBiblio/ref/ccom.htm (original code with no reforms) with CODE DE COMMERCE arts. 632-33 (Fr.) in KozolchyK, Comparative supra note 3 at 334 (the list of acts that will be considered as commercial by the Commercial Code was inspired by the list in the French Code de Commerce). Also analysis comparing the French and Mexican codes KozolchyK, Comparative supra note 3 at 342-350.

143 "Among the most influential features of the [French] Code de Commerce were the rules on its scope, or on the transactions that it would govern. Numerous commercial codes throughout the civil law world adopted its so-called «objective» approach...". Kozolchyк, Comparative supra note 3 at 332 .

144 See id. at 332-34, 342-47. Also see the comparison noted in supra note142. 
It is therefore important to have at least an idea of the archetypal merchant Napoleon used as a model in his code. ${ }^{145}$

The first issue found with the Code de Commerce is that Napoleon did not seem to have as much interest in its drafting as he had for the Code Civil. ${ }^{146}$ While a committee was created to draft a new commercial code in 1801, the result was apparently submitted to the wrong section of the Council of State and was left archived for years. ${ }^{147}$ The project was revived due to a case of fraudulent bankruptcy. ${ }^{148}$ Napoleon was moved more by the need to create a more stringent bankruptcy law than by the need for a commercial code. ${ }^{149}$

In addition to the emperor's lack of interest, there was also the fact that Napoleon did not have a good image of merchants or commerce. ${ }^{150}$ Both Prof. Kozolchyk and "The Cambridge Modern History" describe Napoleon's perception as one of "hatred of speculation and of the free transfer of land", 151 while indicating that Napoleon had two main concerns when reviewing the progress in the drafting of the Code, particularly in relation to the issue of jurisdiction over promissory notes and bankruptcies. ${ }^{152}$

The first point was Napoleon's distrust of promissory notes. "The Cambridge History" mentions the concern Napoleon had regarding commercial courts resolving issues where one of the parties had declared the intention of being bound by the laws of commerce. ${ }^{153}$ "Napoleon argued strenuously that no one, save a merchant, should be liable to imprisonment for failing to meet an obligation contracted by a promissory note". ${ }^{154}$ As a result of Napoleon's arguments, "[u]ncommercial persons and uncommercial transactions were exempted from the severe penalties by which the commercial Courts were empowered to enforce the payment of negotiable instruments". ${ }^{155}$

The second issue also reflects Napoleon's disdain of the merchant class. The original proposals for bankruptcy regulation were not severe enough for the emperor. ${ }^{156}$ “Bankruptcies... take away men's fortunes without destroy-

145 For a more in-depth discussion of the archetypal merchant in the French Code de Commerce, see Kozolchyк, Comparative supra note 3 at Chapter 10.

146 See Kozolchy, Comparative supra note 3 at 327-328.

147 The Cambridge Modern History, IX 177 (A. W. Ward, G. W. Prothero, \& Stanley Leathes eds., 1907) [Hereinafter Cambridge History].

148 Id.

149 See Id. Also Kozolchyк, Comparative supra note 3 at 328.

150 See Kozolchyk, Comparative supra note 3 at 328-329.

151 Cambridge History supra note 147 at 177. Analysis performed by Prof. Kozolchyk. KozolchyK, Comparative supra note 3 at 329.

152 Cambridge History supra note 147 at 177-178. See also analysis by Kozolchyk, ComPARATIVE supra note 3 at 328-329.

153 Id.

154 Id.

155 Id.

156 Id. 
ing their honour; and that is what it is important to destroy". ${ }^{157}$ While the regulation of bankruptcy ended up not as severe as Napoleon wanted, ${ }^{158}$ this quote shows the real concerns the emperor had over the regulation of commerce.

An important distinction should be made here. While the Cambridge History quote mentions Napoleon's disdain for promissory notes, ${ }^{159}$ it later reveals that Napoleon "was unwilling to see bills of exchange or other negotiable instruments used by those that were not in business". ${ }^{160}$ Bills of exchange were particularly troublesome as these were the main instruments used to avoid the accusation of usury. ${ }^{161}$

Dr. Kozolchyk explains that the French Code de Commerce was not enacted as a way to bring certainty and fair and equitable adjudication in favor of merchants, but as a way to "protect non-merchants, and especially the bourgeois, from tricky consequences associated with commercial instruments". ${ }^{162}$ This derogatory view of commerce was not exclusive to the emperor, as it was common throughout Europe at that time. ${ }^{163}$ These facts help understand why "Pardessus has complained that the [Napoleonic] Code of Commerce was more carelessly drafted than any of the other Codes...". 164

The archetypal merchant one encounters in the French Code de Commerce is, therefore, the opposite of the one found in the Ordenanzas. The merchant in the Code de Commerce is not someone to be trusted, but rather someone to be

157 A quote attributed to Napoleon in "The Cambridge History." Cambridge History supra note 147 at 178. See also KozolchyK, Comparative supra note 3 at 328-29.

158 Cambridge History supra note 147 at 178. See also KozolchyK, Comparative supra note 3 at $329-332$.

159 Id.

160 Cambridge History supra note 147 at 177.

"His was not a concern for providing the legal world with a definitive listing of commercial acts for the benefit of merchants in search of commercial code certainty and informal, quick and fair or equitable adjudication; it was to protect non-merchants, and especially the bourgeois, from tricky consequences associated with commercial instruments". KozOLCHYK, Comparative supra note 3 at 329.

161 "[A]n as the reader will recall from the discussion of the "Red Ink" case... the reason why the "courtesan" (as Napoleon referred to her) had inserted the distantia loci clause in her bill of exchange was to prevent its nullity as a face-to-face or inter praesentes usurious loan". Kozolchyк, Comparative supra note 3 at 388.

162 Kozolchyк, Comparative supra note 3 at 329.

163 "In the early-modern world, and especially in Catholic France, the age-old Christian belief that the pursuit of profit is sinful continued to exert significant force, and commerce was therefore viewed by many with suspicion and distaste. The evils of usury, for example, were vociferously decried throughout the eighteenth-century". Amalia D. Kessler, Enforcing Virtue: Social Norms and Self-Interest in an Eighteenth-Century Merchant Court, 22 Law \& Hist. Rev. 71, 74 (2004). First seen in Kozolchyк, Comparative supra note 3 at 308 n65.

164 Cambridge History, supra note 147 at 178. See also Kozolchyk, Comparative supra note 3 at 330 . 
feared and heavily regulated. It is thus to be expected that those commercial codes based on the French Code de Commerce will have a similar treatment of merchants.

\section{The Archetypal Merchant in the Mexican Commercial Code of 1889}

The first article of the Commercial Code of 1889 indicates that it shall only apply to acts of commerce. ${ }^{165}$ The following article indicates that " $[1]$ acking provisions in this code, acts of commerce shall be regulated by the provisions of ordinary law". 166 This is clearly different from the Ordenanzas of Bilbao, which allowed commercial disputes to be settled with "the truth known and good faith according to the customs of merchants". ${ }^{167}$ In addition, the Ordenanzas required disputes to be resolved orally and without recourse to the "writings of lawyers". 168

The 1889 Commercial Code removes the possibility of using commercial customs or good faith as the basis for commercial decisions. ${ }^{169}$ This removal previously appeared in the Commercial Code of 1884 as seen in the case of In re Successors of Agustin Meeser. ${ }^{170}$ Article 2 of the Commercial Code still uses

165 Código de Comercio [Cod. Com. 1889] [Commercial Code 1889], 1, Diario Oficial del Supremo Gobierno de los Estados Unidos Mexicanos [now Diario Oficial de la Federación], October 7-December 13, 1889 (Mex.) http://wrewdiputados.gob.mx/LeyesBiblio/ref/ccom. $\mathrm{htm}$ (original code with no reforms).

166 "A falta de disposiciones de este Código, serán aplicables á los actos de comercio las del derecho común". COD. Com. 1889 art. 2 (translation by author). Whether the phrase "common law" in Art. 2 of the Commercial Code 1889 refers to the Civil Code was resolved when the Commercial Code was amended in 1996 to read "Lacking regulations in this Code and other commercial laws, commercial acts shall be regulated with the ordinary law established in the Civil Code for federal issues". ["A falta de disposiciones de este ordenamiento y las demás leyes mercantiles, serán aplicables a los actos de comercio las del derecho común contenidas en el Código Civil aplicable en materia federal"']. A new problem appeared that year, as there was no Civil Code for federal issues back then. Thus, the Civil Code for the Federal District was used. Miguel Acosta Romero, Comentarios a las Reformas al Código de Comercio, in: XV Congreso Mexicano de Derecho Procesal 693, 695 (UNAM e Instituto Mexicano de Derecho Procesal 1998), http://biblio.juridicas.unam.mx/libros/2/745/34.pdf (translated by author).

167 Ordenanzas de la Ilustre Universidad y Casa de Contratación de la M.N. y M.L. Villa de Bilbao [Ordenanzas of Bilbao] Ch. 1, Art. 6. (1737 and 1814), as amended in 1818 (Spain). See supra note 102 and accompanying text.

168 Ordenanzas of Bilbao Ch. 1 Arts. 6 and 7. See also supra note 121 and accompanying text.

169 Except for Art. 333, which refers to commercial customs to resolve issues regarding a contract of deposit (but only after applying the text of the contract). CoD. Com. 1889 Art. 333.

170 “[G]onforme a la prevención del art. 4 del [Código de Comercio de 1884], éste tiene por base el Civil cuyos preceptos modifica sólo en la parte estrictamente necesaria para fijar la naturaleza de los negocios mercantiles y determinar los derechos y obligaciones que de ellos se derivan..." [[A] ccording to Art. 4 of the [Commercial Code of 1884], the Commercial Code is based on 
the Civil Code (in this case the Federal Civil Code) as a supplement when the Commercial Code lacks appropriate regulation on an issue. ${ }^{171}$ Commercial custom has reappeared in the Commercial Code, but with very limited applicability. ${ }^{172}$

As in the case of customs, in 1889 legislators removed the support given to the use of good faith that was characteristic of the Ordenanzas of Bilbao. ${ }^{173}$ While the Ordenanzas mentioned the use of good faith at least 10 times, ${ }^{174}$ the Commercial Code 1889 only included the use of "good faith" three times. Furthermore, the mention of good faith differed from that in the Ordenanzas as it was not used as a basis for issuing judicial decisions.

The first mention of "good faith" appears in Article 393 of the Commercial Code 1889 indicating that:

Art. 393. Any insurance contract shall be void:

Due to the proven bad faith of any of the parties at the time of entering into the agreement;

Due to the inaccurate declaration of the insured, even if made in good faith, as long as it affects the calculation of risk... ${ }^{175}$ [emphasis added]

As seen, good faith (and in this case bad faith) is only used as a method to void a contract. This is not the same type of good faith used in the Ordenanzas, which placed confidence in merchants' actions. In the case of the second

the Civil Code, whose stipulations the Commercial Code amends only when absolutely necessary in order to establish the nature of commercial business practices and to determine the rights and obligations derived thereof...] In re Successors of Agustín Meeser, in Anuario (1888) supra note 125 at 496 (emphasis in original) (translation by author).

171 Código de Comercio [Cod. Com.] [Commercial Code], as amended, Art. 2, D.O.F. October 7-December 13, 1889 (Mex.). See also Acosta Romero, supra note 166 at 695.

172 On January 2005, Article 6 bis was added to the amended Commercial Code. Art. 6 bis orders merchants to act according to their customs (called "usos honestos en materia industrial o comercial"). In July 1993, the Commercial Code was amended in order to regulate commercial arbitration. Art. 1445 now indicates that an arbitration tribunal has to take into account commercial customs in its decisions (“...el tribunal arbitral decidirá con arreglo a las estipulaciones del convenio y tendrá en cuenta los usos mercantiles aplicables al caso"). CoD. Com. as amended Arts. 6 bis., 1445.

173 See supra Section "The archetypal merchant in the Ordenanzas of Bilbao".

174 See supra note 102 and accompanying text.

175 “Art. 393. Será nulo todo contrato de seguro:

I. Por mala fe probada de alguna de las partes al tiempo de celebrarse el contrato;

II. Por la inexacta declaración del asegurado, aun hecha de buena fe, siempre que pueda influir en la estimación de los riesgos...”.

Código de Comercio [Cod. Com. 1889] [Commercial Code 1889], Art. 393, Diario Oficial del Supremo Gobierno de los Estados Unidos Mexicanos [now Diario Oficial de la Federación], October 7-December 13, 1889 (Mex.) http://wrerr.diputados.gob.mx/LeyesBiblio/ref/ccom. htm (translation by author) (original code with no reforms). 
subsection, mistrust of good faith is evident, as even proving the existence of good faith will not prevent voiding the contract (as long as the mistake of the insured affected the cost of the insurance).

This shift in how merchants are regarded is evident when comparing the Ordenanzas of Bilbao treatment of bankruptcies with how they are dealt with in the Commercial Code. It bears remembering that the Ordenanzas divided bankrupt merchants into three categories, and that only the last category had the element of malice. ${ }^{176}$ The Ordenanzas were also very lenient with regard to bankrupt merchants. ${ }^{177}$ Merchants retained their rights (except perhaps for the right to have a voice in the Universidad) unless there was fraud with respect to the bankruptcy. ${ }^{178}$

It is also important to recall that the Commercial Code was heavily influenced by the French Code de Commerce of 1807, and that Napoleon did not have a very favorable opinion of merchants. ${ }^{179}$ It is therefore no surprise to find a poor image of merchants in the Commercial Code. The first issue is that any person declared bankrupt is forbidden from practicing commerce until they have been rehabilitated. ${ }^{180}$ Also, the classification of bankruptcies may look similar to that of the Ordenanzas, but the resemblance is only superficial.

The Commercial Code of 1889 also divides bankruptcies into three categories. ${ }^{181}$ Nevertheless, compared to the Ordenanzas, the Commercial Code is not as lenient with bankrupt merchants. The categories in the Commercial Code are "fortuitous [incidental]," "blameworthy", and "fraudulent [malicious]". ${ }^{182}$ One should be careful not to be confused by the nomenclature, as the "fortuitous" category is not the same as bankruptcy due to shipwrecks mentioned above. ${ }^{183}$

Article 954 stipulates that a bankruptcy is regarded fortuitous when it does not fall under the other two categories. ${ }^{184}$ This is an issue, as the other cat-

176 See supra notes 111-117 and accompanying text.

177 See supra notes 112, 113, 115, 116 and accompanying text.

178 See supra notes 112, 113, 115, 116, 119 and accompanying text.

179 See supra notes 96, 142, 150, 151 and accompanying text.

180 "Art. 12. [The following] are forbidden from practicing commerce... II. Bankrupt merchants that have not been rehabilitated". ["Art. 12. No puede ejercer el comercio... II. Los quebrados que no hayan sido rehabilitados"]. Código de Comercio [Cod. Com 1889] [Commercial Code 1889], Art. 12, Diario Oficial del Supremo Gobierno de los Estados Unidos Mexicanos [now Diario Oficial de la Federación], October 7-December 13, 1889 (Mex.) http://wrere.diputados.gob.mx/LeyesBiblio/ref/ccom.htm (translation by author) (original code with no reforms).

181 Cod. Com. 1889 Art. 953.

182 “Art. 953. La quiebra es fortuita, culpable o fraudulenta". CoD. Com. 1889 Art. 953 (translation by author).

183 See supra note 113 and accompanying text.

184 "Art. 954. A bankruptcy will be regarded as fortuitous if, after being examined, it does 
egories include 11 and 21 circumstances, respectively, ${ }^{185}$ which along with the broad scope of some of them, make it difficult to be classified as fortuitous.

Moreover, as opposed to the Ordenanzas, which had a list of actions that may be considered malicious but also left the question open as to whether malice or fraud could be found, ${ }^{186}$ the Commercial Code has a list of 21 situations considered fraudulent regardless of whether the actions may be customary among merchants doing business at that place and time or whether the merchant had malicious intent. ${ }^{187}$

These examples indicate that the archetype that appears in the Commercial Code is not the trustworthy merchant implicit in the Ordenanzas. The archetypal merchant in the Commercial Code is closer to the view Napoleon had of merchants, ${ }^{188}$ that is, an untrustworthy individual who must be regulated in order to prevent them from abusing other individuals. This control is exerted by establishing clear rules for their actions in the Code while not allowing for the independent evolution of commercial law, which is usually achieved through the application of customary law.

\section{Examples of the Archetypal Merchant in Case Law}

The Commercial Code's limitations on the use of customs or good faith as bases for issuing decisions also restricted the use of an archetypal merchant in case law. Instead, judges limited themselves to a strict application of the Commercial and Civil Codes. ${ }^{189}$

not fall under any of the situations described in the next two articles". ["Art. 954. La quiebra es fortuita si al hacer su calificación no se encontrará comprendida en ninguno de los casos previstos en los dos artículos siguientes"]. CoD. Com. 1889 Art. 954 (translation by author).

185 Código de Comercio [Cod. Com. 1889] [Commercial Code 1889], arts. 955, 956, Diario Oficial del Supremo Gobierno de los Estados Unidos Mexicanos [now Diario Oficial de la Federación], October 7-December 13, 1889 (Mex.) http://wrerc.diputados.gob.mx/LeyesBiblio/ref/ ccom.htm (original code with no reforms).

186 The list starts by saying that merchants, despite being aware of the poor state of their businesses "...risk the wealth of others with malice and fraud...", [“...conociendo su mal estado, no obstante él, arriesgan los caudales ágenos con dolo y fraude...”], Ordenanzas de la Ilustre Universidad y Casa de Contratación de la M.N. y M.L. Villa de Bilbao [Ordenanzas of Bilbao] Ch. 17, Art. 4 (1737 and 1814), as amended in 1818 (Spain) (translation by author).

187 Some examples are: not keeping books or keeping them in a manner inconsistent with that established by the CóD. Com. 1889 (subsection I); buying goods not in his own name, but for a third party or selling goods without receiving the money either before or after the bankruptcy is declared (subsection VI); and not keeping inventories as prescribed in the Commercial Code, the company statutes or a contract (subsection XIX). CoD. Com. 1889 Art. 956.

188 See supra "The influence of French doctrine".

189 The cases studied in this section are limited to the cases that appeared in the Diario de Jurisprudencia del Distrito y Territorios Federales [hereinafter Diario] from 1904 to 1914. These were studied due to their proximity to the creation of the Commercial Code and be- 
A. Successors of Bustamante 7.A. v. Romano Pedro ${ }^{190}$

Successors of Bustamante 7.A. v. Romano Pedro is a very interesting case for several reasons. First, it illustrates how a Mexican appellate court applies the Spanish Commercial Code to a Mexican-Spanish continuing-type of transaction. Second, while it was a case between merchants and the court therefore did not have to take into account non-commercial behavior, it had to assume that the practice in question was lawful in both countries. Third, the case referred to the use of bills of exchange, which Napoleon viscerally distrusted as usurious and tricky. ${ }^{191}$ Finally, the facts of the case indicate the creation of customary practices between the parties. Of equal importance, is that the customary behavior involved in this case is the contracting parties' "course of dealing" in previous transactions and not a statutorily or judicially approved custom or usage of trade. The resolution of this case is a good indicator of how Mexican courts dealt with customary practices back then.

The facts of the case were as follows: Romano sent bills of exchange in Pounds Sterling to Bustamante, who was in Santander, Spain, so that Bustamante could negotiate the bills in Spain. ${ }^{192}$ The agreement between Romano and Bustamante was that Bustamante would negotiate the bills as soon as he received them; however, they started to develop the custom of waiting a couple of days in hopes of a better trade price. ${ }^{193}$ The system worked until 1898, when Bustamante died. ${ }^{194}$

After Bustamante's death, his successors decided to continue the commercial relationship with Romano, ${ }^{195}$ who accepted the succession and continued sending bills of exchange to be negotiated. ${ }^{196}$ The Bustamante's successors continued the custom of holding the bills in hopes of better deals, ${ }^{197}$ even though the instructions given by Romano were still to sell as soon as they received the bills of exchange. ${ }^{198}$ The issue that brought the case before the Mexican court was that at some point between 1898 and 1899, after Ro-

cause they were issued by the government that existed before the appearance of the Mexican Constitution of 1917. All the volumes are available at $h$ ttp://catalog.hathitrust.org/Record/010428 147?type $\% 5 B \% 5 D=$ subjectElookfor $\% 5 B \% 5 D=\% 22 \% 20$ Law $\% 2$ reports $\% 2 C \% 20$ digests $\% 2 C \% 20$ etc. $\% 20$ Mexico. $\% 22 \Theta f t=$.

190 Successors of Bustamante F.A. v. Romano Pedro, in Diario de Jurisprudencia del Distrito y Territorios Federales [Diario II], Tomo II, May, June, July and August 1904, page 642 (Victoriano Pimentel, ed.) (Tribunal Superior del Distrito, Segunda Sala. May 26, 1904).

191 See supra notes 152-155 and accompanying text.

192 Successors of Bustamante F.A. v. Romano Pedro, in Diario II supra note 190 at 643.

193 Successors of Bustamante F.A. v. Romano Pedro, id.

194 Successors of Bustamante 7.A. v. Romano Pedro, id.

195 Successors of Bustamante F.A. v. Romano Pedro, id.

196 Successors of Bustamante F.A. v. Romano Pedro, id.

197 Successors of Bustamante F.A. v. Romano Pedro, id.

198 Successors of Bustamante F.A. v. Romano Pedro, id. at 645. 
mano sent bills to Bustamante's successors, they held on to the bills for several months due to fluctuations in the exchange rate of pounds sterling. ${ }^{199}$

The Bustamante's successors could not find an appropriate moment to sell the bills until they finally did so in $1900 .{ }^{200}$ The real issue in the case was that in the end, the Bustamante's successors sought payment from Romano for their services. ${ }^{201}$ Bustamante's successors claimed a debt of $\$ 24,600.90$ pesetas, while Romano claimed that he only owed $\$ 2,545.08$ pesetas. ${ }^{202}$ The difference in the amount of the debt stems from the issue of when the bills, which represented $\mathcal{E} 1,400$ pounds, should have been negotiated; that is, whether they should have been negotiated when the successors of Bustamante received them (resulting in the amount claimed by Romano) or when they were finally negotiated according to the usage created by the parties (resulting in the amount claimed by Bustamante's successors).

The Second Chamber of the Superior Court of the Federal District was an appellate court. It applied the Spanish Commercial Code, but not before comparing it with the Mexican Commercial Code and deciding that the applicable rules were similar. ${ }^{203}$ The bases for the Second Chamber's decision were Articles 68 of the (Mexican) Commercial Code and 57 of the Spanish Commercial Code that established "the legal principle that anything agreed and consented to by the parties is the supreme law of contracts, giving preference to the will of the parties, expressed in good faith and with full clarity, over requirements and formalities that do not affect the essential conditions of any convention". ${ }^{204}$

The Second Chamber interpreted these articles in a strict manner, indicating that Romano had ordered Bustamante and his successors to negotiate the bills as soon as they received them. ${ }^{205}$ The Second Chamber did this even though it acknowledged that "Romano was satisfied and even grateful that [Bustamante's successors] had delayed the sale in certain operations...".206

199 Successors of Bustamante 7.A. v. Romano Pedro, id. at 644.

200 There were several letters between Romano and Bustamante's successors, as well as several transactions between them during this time. Nevertheless, it is not necessary to elaborate further on the facts for the purposes of this article. Successors of Bustamante F.A. v. Romano Pedro, id. at 650 .

201 Successors of Bustamante 7.A. v. Romano Pedro, id. at 649.

202 Successors of Bustamante F.A. v. Romano Pedro, id.

203 Successors of Bustamante 7.A. v. Romano Pedro, id. at 650, 653, 659.

204 "[E]l principio jurídico de que lo pactado y convenido es la suprema ley de los contratos, prefiriéndose en todo caso la voluntad de las partes, manifestada de buena fe y con toda claridad, á requisitos y formalismos que no afectan las condiciones esenciales de toda convención". Successors of Bustamante F.A. v. Romano Pedro, id. at 650 (translation by author).

205 This was proven with several letters sent by Romano to Bustamante and his successors. Successors of Bustamante 7.A. v. Romano Pedro, id. at 654-655.

206 “[E]l señor Romano estuvo conforme y aun les agredeció en ciertas operaciones, que hubieran demorado la venta...". Successors of Bustamante F.A. v. Romano Pedro, id. at 654 (translation by author). 
This had no effect according to the reading that the Second Chamber made of the mentioned articles:

Regarding the fact that Romano sometimes tolerated and even approved of the delay in the negotiation of the Pounds Sterling, it must be noted that those declarations referred to operations that were already concluded and to his benefit. It is only natural to expect that he would be grateful for the interest and profit obtained. Nevertheless, this does not and cannot rescind the instructions previously communicated, which are, as we have just seen, the nature and essence of the contract of the commission. ${ }^{207}$

The Second Chamber did not believe that the course of dealing and usage established by the parties with the customary manner in which they engaged in their transactions had any weight. Moreover, the Second Chamber did not ask what a reasonable merchant in a similar situation would have done; in other words, what the custom was among merchants dealing in these types of transactions. The Second Chamber imposed a strict application of the Code, which resulted in a decision that benefited Romano.

The Second Chamber decided to grant payment to the successors of Bustamante for the sum of $\$ 6,429.71$ pesetas, which although more than the amount claimed by Romano, was markedly lower than the $\$ 24,600.90$ pesetas claimed by the successors of Bustamante. ${ }^{208}$

\section{B. Murguía v. La Mexicana, Compañia Anónima Nacional de Seguros de Vida209}

The case of Murguía deals with a contractual relationship between a merchant and a non-merchant. In its ruling, the court creates an archetype of the

207 "Por lo que hace a que el señor Romano algunas veces tolerara y aun diera su aprobación la demora en realizar las libras esterlinas, es necesario fijarse en que esas manifestaciones se referían a operaciones ya consumadas y en su provecho; de modo que naturalmente, no había otra cosa que hacer, sino agradecer el interés manifestado y el lucro obtenido; pero esto no destruye ni podía destruir las instrucciones antes comunicadas, porque éstas, como lo acabamos de ver, son de la naturaleza y esencia del contrato de comisión”. Successors of Bustamante 7.A. v. Romano Pedro, id. at 655 (translation by author) (emphasis added).

208 The Second Chamber reached this amount after deciding that the bills should have been negotiated in July 1898, which was around the time the successors of Bustamante received several bills of exchange from Romano. Successors of Bustamante 7.A. v. Romano Pedro, id. at 645,658 .

209 Murguía v. La Mexicana, Compañía Anónima Nacional de Seguros de Vida [hereinafter Murguía], in Diario de Jurisprudencia del Distrito y Territorios Federales [Diario XXVIII], Tomo XXVIII, January, February, March and April 1913, page 513 (Victoriano Pimentel, ed.) (although the name of the party appears as "Murguía" in the heading of the report, the name that appears in the body is "Murguía") (Juzgado Segundo de lo Civil, June 12, 1912). 
model behavior expected from a non-merchant. The case is also interesting as it deals with an insurance contract, which is one of the few contracts that the Commercial Code stipulates should be performed and interpreted in good faith. ${ }^{210}$

Murguía was a case decided by the Second Civil Court, which was a trial court. ${ }^{211}$ The case involved a life insurance policy between Manuel Inorosa and "La Mexicana" insurance company. ${ }^{212}$ The company sent the insurance policy to a banker, instructing Inorosa to make the first payment and to collect the policy. ${ }^{213}$ Murguía, who was Inorosa's spouse and later widow and estate trustee, paid by bank deposit, but failed to collect the policy, obtaining instead a receipt of payment. ${ }^{214}$

The Diario indicates that the main issue in the case was whether the person who brought the claim against the insurance company had standing. ${ }^{215}$ Nonetheless, since that person had power of attorney from Murguía and she was the beneficiary of the insurance policy as well as the estate trustee, the claim was declared to be correctly filed. ${ }^{216}$ However, the court spent considerable time determining whether the form of payment contemplated in the policy allowed the insurance to be enforced, which was part of the argument raised by the insurance company's defense. ${ }^{217}$

While the court decided to grant Murguía the payment of the insurance premium, ${ }^{218}$ it is clear that the court treats the commercial and non-commercial parties differently. The court expressed the following about Murguía:

[The fact] that the banker himself retained the [insurance] policy [instead of delivering it to Murguía] did not give her a reason for distrust... as she had faith in the respectability of the insurance company, and believed it impossible that the retention of the policy and the delivery of a receipt in exchange for payment was a ploy against her naïveté as a woman, who had little knowledge about business matters... ${ }^{219}$

210 See supra note 175 and accompanying text.

211 The Diario later indicates that the court was located in Mexico City. The Diario mentions that the Third Chamber confirmed the judgment in 1912. Murguía, in Diario XXVIII supra note 209 at 517, 523.

212 Murguía, in id. at 514.

213 Murguía, in id.

214 Murguía, in id. at 515.

215 The court also mentions an issue regarding court's powers. Murguía, in id. at 517.

216 Murguía, in $i d$. at 517.

217 Murguía, in id. at 519, 521.

218 Murguía, in id. at 523.

219 “[E]l mismo banquero retuvo la referida póliza, sin que esta circunstancia fuese motivo de desconfianza para la persona que llevó la primera exhibición, porque tenía fe en la respetabilidad de la compañía aseguradora, y creía imposible que la retención de la póliza y la entrega de un recibo distinto de ella, en cambio de dicha exhibición, fuese un ardid tendido a 
The court is also reluctant to find malice in Inorosa's actions of, who died one day after the initial payment, ${ }^{220}$ even though Inorosa did not reveal he was seriously ill at the moment of signing his life insurance policy as 1) the bank did not explicitly request this information at that time;221 2) Inorosa honestly answered all the questions asked;222 and 3) Inorosa's economic and family situation did not suggest he would cause his own death in order to collect the insurance money. 223

Moreover, the court decided that neither the fact the complainant failed to collect the insurance policy nor the manner in which the payment was made invalidated the insurance contract. ${ }^{224}$ The court reached this decision based not on a strict application of the Commercial Code but on an interpretation of the documentary evidence presented. ${ }^{225}$ The court also supported its decision by referring to another decision issued by the Court of Cassation of Amiens, France. ${ }^{226}$

Murguía is a good illustration of the importance of judicial assumptions of archetypal commercial versus non-commercial behavior when applying the Commercial Code to commercial and non-commercial parties. As apparent in this court decision, the court assumes an attitude on behalf of the insurer that is purely selfish, non-altruistic and profit-seeking at any cost, while assuming honesty and trusting behavior of a non-merchant:

To try to give another reading to the records of the proceedings... would be to distort the often-referred to life insurance contract, doing away with its altruistic and beneficial tendencies while alienating the insured from the insurer, whose risks and losses (when dealing with corporations) are insignificant, and ignoring the purely commercial nature of said insurer, who pursues no other purpose than profit. ${ }^{227}$

su sencillez de mujer, poco entendida en achaques de negocios...". Murguía, in id. at 515 (emphasis added) (translation by author).

220 Murguía, in id. at 515.

221 Murguía, in id. at 519.

222 This included a question pertaining to previous diseases. Inorosa answered that he had been sick with pneumonia (he died of a pulmonary infection) four years before. The court held that pneumonia is a completely curable disease and that Inorosa could not have caused it on purpose. Murguía, in id. at 522.

223 Murguía, in $i d$.

224 Murguía, in $i d$. at 521.

225 "Pretender dar otra inteligencia a las constancias de autos... sería desnaturalizar el tantas veces expresado contrato de seguros (sic) sobre la vida, quitándole sus tendencias altruistas y bienhechoras y alejando al asegurado del asegurador cuyos riesgos y pérdidas consiguientes (tratándose de sociedades anónimas) son insignificantes y dejando al referido asegurador su carácter netamente de comerciante, que no persigue otro fin que el del lucro". Murguía, in id. at 521 (emphasis added) (translation by author).

226 Murguía, in id. at 522.

227 Supra note 225. 
Thus, this decision eloquently illustrates that while the court was willing to apply its interpretation of commercial law in a non-strict and equitable manner when dealing with non-merchant consumers, who were seen as naive individuals who need to be protected from merchants, the opposite archetypal assumption prevailed with respect to merchants. ${ }^{228}$ It also presents yet more evidence of the French influence on the Commercial Code and the interpretation of commercial law in Mexico.

\section{Compañia del Ferrocarril Mexicano v. Luis Lack229}

The Ferrocarril case involved a trade law dispute and exemplifies the usage that courts sometimes gave to Article 1276 of the Civil Code then in force. ${ }^{230}$ As seen above, the Commercial Code did not allow for the use of good faith or custom to resolve cases. ${ }^{231}$ Since the Civil Code was utilized to supplement the shortcomings of the Commercial Code, ${ }^{232}$ courts often used Article 1276 of the Civil Code, which indicated that contracts legally entered into compelled the parties to accept the consequences characterized by good faith, customs and law. 233

228 It is important to mention that the fact that Murguía was a woman may also have affected the decision of the court, as women did not have an equal status in the Commercial Code 1889 before it was reformed. See Código de Comercio [CoD. Com. 1889] [Commercial Code 1889], Arts. 8, 11, Diario Oficial del Supremo Gobierno de los Estados Unidos Mexicanos [now Diario Oficial de la Federación], October 7-December 13, 1889 (Mex.) http://wrwre. diputados.gob. $\mathrm{mx} /$ LeyesBiblio/ref/ccom.htm (original code with no reforms) (These articles provided that married women needed their husband's authorization to practice commerce even if they had practiced it before getting married).

229 Compañía del Ferrocarril Mexicano, v. Luis Lack [hereinafter Ferrocarril], in Diario de Jurisprudencia del Distrito y Territorios Federales [Diario III], Tomo III, September, October, November and December 1904, page 605 (Victoriano Pimentel, ed.) (Juzgado Segundo de lo Civil. Sep. 1, 1904).

230 "Contracts legally entered into compel [the parties to accept] what was expressed therein as well as their consequences, which according to their nature reflect good faith, custom or law”. In Compañía Ganadera, Sociedad Cooperativa Limitada v. Rafael Pliego [hereinafter Compañía Ganadera], in Diario de Jurisprudencia del Distrito y Territorios Federales [Diario VI], Tomo VI, September, October, November and December 1905, pages 291, 294 (Victoriano Pimentel, ed.).

231 See supra Section 2.

232 "Lacking stipulations in this code, commercial acts shall be regulated with the stipulations of common law". Código de Comercio [Cod. Com. 1889] [Commercial Code 1889], Art. 2, Diario Oficial del Supremo Gobierno de los Estados Unidos Mexicanos [now Diario Oficial de la Federación], October 7-December 13, 1889 (Mex.) http://wrewediputados.gob.mx/ LeyesBiblio/ref/ccom.htm (original code with no reforms) (translation by author). See supra notes 165, 166 and accompanying text.

233 See supra note 230. 
There are a couple of issues with this approach. First, since the article used to supplement the Commercial Code came from the Civil Code, it was using a different archetype, i.e., the archetypal citizen found in the Civil Code. Second, while the application of this article could have encouraged the development of case law similar to that promoted by the Ordenanzas, the truth is that courts applied Article 1276 only with a very limited approach.

In Ferrocarril, a shipment was received by the customs office in Veracruz and sent by train to Mexico City. ${ }^{234}$ A Mr. Luis Lack received the shipment upon its arrival. ${ }^{235}$ The train company charged Lack an amount of money that covered, among other things, the tariffs applied to the shipment. ${ }^{236}$ It was later discovered that the train company had made amistake and that it had paid more to the customs office in Veracruz than what it had charged Lack. ${ }^{237}$ The train company sued Lack for the difference but he refused to pay. ${ }^{238}$

Ferrocarril was a decision of the Second Civil Court of the Federal District, which was a trial court, meaning this decision was not given at the appeal level. ${ }^{239}$ In deciding that Lack had to pay the difference to the train company, the court stated:

From all of this it follows, in a word, that Ferrocarril Mexicano charged Mr. Lack, before paying for him, less than what he actually had to pay. This situation was nothing more than a mistake that can be rectified in accordance with the express provision of the law and in accordance with the principles of good faith that must be observed in all contracts (Articles [1296] and [1276] of the Givil Code). ${ }^{240}$

The court could have asked what a reasonable merchant in that situation would have done. ${ }^{241}$ The court could also have inquired as to what the custom was among merchants in similar situations. Instead, the court applied Article 1276 to decide the case using a limited version of the commercial meaning of good faith.

234 Ferrocarril, in Diario III supra note 229 at 605-06.

235 Ferrocarril, in $i d$. at 606.

236 Ferrocarril, in $i d$.

237 Ferrocarril, in $i d$.

238 Ferrocarril, in $i d$.

239 Ferrocarril, in id. at 605, 607.

240 "De todo esto resulta, en una palabra, que el Ferrocarril Mexicano cobró al señor Lack, antes de pagar por él, una cantidad menor de la que con posterioridad tuvo en realidad que pagar, lo que no envuelve sino un error subsanable, según disposición expresa de la ley y según los principios de la buena fe que debe observarse en todos los contratos (artículos [1296] y [1276] del Código Civil.)". Ferrocarril, in id. at 607 (translation by author).

241 Such a question would have been similar to what Judge Friendly asked in the Frigaliment case. See supra notes 22-25 and accompanying text. 


\section{Compañia Ganadera, Sociedad Cooperativa Limitada v. Pliego Rafael242}

The case of Compañia Ganadera also deals with the limited use that courts gave to article 1276 of the Civil Code. Compañia Ganadera referred to a contract for the sale of a butcher's shop between the defendant, Rafael Pliego, and a cattle company, the plaintiff. Pliego refused to pay and argued, inter alia, that the plaintiff's company did not exist and therefore lacked standing. ${ }^{243}$

The Second Chamber of the Superior Court of the Federal District decided this case, indicating that it was an appeal. ${ }^{244}$ The court found in favor of the cattle company and rejected all the arguments Pliego made. ${ }^{245}$ Regarding the alleged lack of standing the court found that:

Having acknowledged the existence of the company and its representatives when he agreed to the sale of the butcher's shop and the purchase of the meat, Mr. Pliego cannot now deny its existence since in accordance with Article [1276] of the Civil Code, which amends the [Commercial Code]... it would be contrary to good faith for Mr. Pliego, after having enjoyed the benefits of entering into a contract with a company whose existence he had acknowledged, to then disclaim it in order to no longer meet the obligations he had acquired in compensation for the benefits obtained. ${ }^{246}$

The court uses the concept of good faith in this case as a means to invalidate Pliego's hyper-technical, formalistic arguments. While similar to the application of good faith in the Ordenanzas, ${ }^{247}$ this situation is different in that it involves a negative application of the principle of good faith. In other words, the court determined that signing a contract and then denying the existence of one of the parties who entered into it would represent the opposite of good faith. In that sense, the court uses good faith only as a way to validate the contract and not as a vehicle of jurisprudence.

242 Compañia Ganadera, in Diario VI supra note 230. (Tribunal Superior del Distrito, July 11 , 1905).

243 Compañia Ganadera, in Diario VI supra note 230 at 294.

244 Compañia Ganadera, in id. at 295.

245 Compañia Ganadera, in id.

246 " $[\mathrm{H}]$ abiendo reconocido el señor Pliego la existencia de la sociedad y su representación al contratar con ella la venta de la carnicería y la compra de la carne, no la puede hoy negar, pues conforme al artículo [1276] del Código Civil, supletorio del [Código de Comercio] ...y sería contrario á la buena fe, que después de haberse aprovechado el señor Pliego del contrato celebrado con una persona moral, cuya existencia había reconocido, la desconozca para dejar de cumplir las prestaciones á que se había obligado, en compensación del lucro obtenido". Compañia Ganadera, in id. at 294 (translation by author).

247 See supra Section 1 The archetypal merchant in the Ordenanzas of Bilbao. 


\section{Conclusion}

In this article, I have presented the idea that the cautious approach taken by the Commercial Code legislators regarding the prospect of allowing anyone but the federal government to establish commercial law, coupled with the influence of French legal doctrine, gave Mexico a Commercial Code with a very different - and less commercial - archetype from that found in the Ordenanzas of Bilbao. While the Ordenanzas were based on the idea of a trustworthy merchant, the Commercial Code was drafted on the basis of an untrustworthy individual whose activities had to be regulated in order to protect others when dealing with them, especially ordinary non-merchant citizens.

Regarding a possible reform of Mexican commercial laws, a first step would be to remove the use of the Civil Code to fill the gaps in the commercial legislation. I have touched upon this issue previously in my paper "The Need to Remove the Civil Code from the Mexican Commercial Laws, The Case of Offers and Firm Promises". 248 The removal of the Civil Code to fill gaps in commercial law would open the possibility to employ commercial good faith and commercial customs and practices to advance commercial law. Moreover, this would also mean that commercial law would have its own doctrines, such as a general doctrine of contracts. ${ }^{249}$

As to the best form in which to create a new Commercial Code, I would suggest following the example given in instruments such as the "Uniform Customs and Practice for Documentary Credits (UCP)", a quasi-legislative instrument used by practitioners of letters of credit around the world. ${ }^{250}$ This instrument was created by bankers and merchants who have been enacting and reforming these rules for the regulation of international documentary credit transactions for decades. ${ }^{251}$

248 Iturralde, supra note 84.

249 See Usos y costumbres mercantiles. Validez de su empleo en la interpretación de contratos mercantiles, Cuarto Tribunal Colegiado en Materia Civil del Primer Circuito [T.C.C.] [Fourth Civil Court of the First District], Semanario Judicial de la Federación y su Gaceta, Novena Época, Tomo XXXI, enero de 2010, Tesis I.4o.C.254 C, Page 2267 (Mex.). Iturralde, supra note 84 at 28.

250 See ICG Uniform Customs and Practice for Documentary Credits-UCP 600, International Chamber of Commerce, http://store.iccwbo.org/icc-uniform-customs-and-practice-for-documentary-credits.

251 See Dan Taylor, The Complete UCP, Texts, Rules and History 1920-2007. Also Boris Kozolchyk, Commercial Letters of Credit in the Americas, A Comparative Study of Contemporary Commercial Transactions 83-85 (1966). Also Raul Iturralde Gonzalez, Commercial Archetypes, Practices and Principles: Tools for a Market Sensitive, 21 st Century Commercial Law (2017) (unpublished SJD dissertation, University of Arizona) (on file with author). 
Another instrument that can be used as basis for a commercial law based on commercial practice is the "TransLex" list. ${ }^{252}$ The TransLex list was compiled by Prof. Klaus Peter Berger, who has been working on collecting principles of transnational commercial law. ${ }^{253}$ The TransLex list has 143 principles, including the principles of good faith and reasonableness, ${ }^{254}$ as well as principles for issues such as contracts, or damages. ${ }^{255}$ Since every principle mentioned on the TransLex list is supported by legal doctrine, arbitral decisions, and examples of contract clauses ${ }^{256}$ the list touches upon commercial practice (although, more input from merchants is, in my opinion, desirable).

The idea of an untrustworthy merchant needs to be eliminated from commercial laws in Mexico. Following historical and contemporary examples, it is necessary to include those involved in commercial activities, i.e. merchants, bankers, carriers, etc., in the creation and development of commercial laws. This is not a call for the legislature to relinquish power, as was feared by previous code drafters, but a call to base commercial laws on an archetype more in line with the experience and needs of Mexican merchants.

252 Trans-Lex, Center for Transnational Law (University of Cologne) http://wrwre.trans-lex. org/principles.

253 Id.

254 Id.

255 Id.

256 Id. 


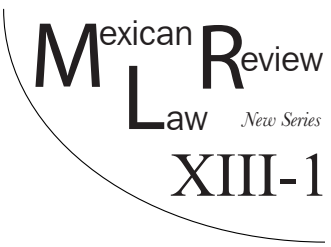

\title{
CHALLENGES OF COMPENSATION AND REPARATION FOR LOSS AND DAMAGE RELATED TO THE ADVERSE EFFEGTS OF CLIMATE CHANGE
}

\author{
Jorge Gabriel Arévalo García*
}

\begin{abstract}
Anthropogenic climate change has and will have unavoidable adverse effects despite mitigation and adaptation policies. Therefore, the financial burden of the costs of loss and damage must be distributed fairly and proportionally. This implies that those responsible for climate change must take responsibility and compensate those who suffer losses and, if possible, repair the damages related to this phenomenon. However, climate justice has been limited by the lack of a causal link between a specific climate change effect and specific damages or losses. Accordingly, this article discusses the compensation and reparation of losses and damages related to the adverse effects of climate change, as a stream applicable after mitigation and adaptation policies. In addition, this article reviewes the implications of the relevant findings that established the existence and development of climate change as a problem that affects the enjoyment of human rights, to argue how the theory of human rights can contribute to the current legal model for reparation and compensation for losses and damages associated with climate change. Also, due to the impossibility of obtaining a legally binding agreement as a structure for integration, and to adequately address the problem of causes, consequences, benefits and burdens, vulnerable groups ought to be the most affected.
\end{abstract}

KEYWORDS: Loss and damage, reparation, compensation, attribution, causal nexus, Human Rights.

Resumen: El cambio climático antropogénico tiene y tendrá efectos adversos inevitables a pesar de las políticas de mitigación y adaptación. Esto implica que la carga financiera de los costos de pérdidas y daños debe distribuirse de manera justa y proporcional. Los responsables del cambio climático deben asumir la responsabilidad y compensar a quienes sufren pérdidas y, si es posible, reparar los daños relacionados con este fenómeno. Sin embargo, la justicia climática se ha visto limitada por la falta de un vínculo causal entre un evento

* Visiting Researcher at the Walther Schücking Institute for International Law of Christian-Albrechts-Universität Zu Kiel. Email: arevalo.garcia.jg@gmail.com. 
específico de cambio climático y daños o pérdidas especificas. Este artículo aborda la compensación y reparación de pérdidas y daños relacionados con los efectos adversos del cambio climático, como una corriente aplicable después de las políticas de mitigación y adaptación. Asimismo, este artículo revisa las implicaciones de hallazgos relevantes que establecieron la existencia y el desarrollo del cambio climático como un problema que tiene implicaciones negativas para el disfrute de los derechos humanos, para argumentar cómo la teoría de los derechos humanos puede contribuir al modelo legal actual de reparación y compensación por daños y perjuicios ambientales. Además, debido a la imposibilidad de obtener un acuerdo legalmente vinculante como una estructura para la integración y para abordar adecuadamente el problema de las causas, consecuencias, beneficios y cargas, los grupos vulnerables serán los más afectados.

Palabras clave: Pérdidas y daños, reparación, compensación, atribución, nexo causal y derechos humanos.

\section{Table of Contents}

I. INTRODUCTION

II. Summary of the Science of Climate Change....

III. Compensation for Loss and Damage Related to the Adverse Effects of Glimate Ghange

1. The Third Aspect of Climate Change Applicable After the Mitigation and Adaptation Policies.

2. The Attribution and the Causal Link of Climate Change

IV. The theory of Human Rights and Compensation for

Damages and Losses Related to Climate Ghange.

V. Conclusions

\section{INTRODUCTION}

The vulnerability of humans and ecosystems to the impacts of climate change has increased the debate on the efficiency and effectiveness of national and international responses to mitigate and adapt to this global issue. For many countries located in the Intertropical Convergence Zone (ITCZ), the climatic threats refer to the changes in the volume of precipitation and the rise of temperature. ${ }^{1}$ With these observed trends, the intensity and frequency of hydrometeorological hazards are expected to increase, such as droughts, heat waves, hurricanes, tropical storms, floods, among others. These disturbances

1 Michael P. Byrne et al., Response of the Intertropical Convergence Zone to Climate Change: Location, Width, and Strength, 4 Current Climate Change Reports 355, 370 (2018). 
are affecting the resilience of many ecosystems, which is likely to be overcome. $^{2}$

Some of the negative climate effects on environmental and human systems have an impact on biodiversity, marine and coastal systems, forests, hydrology and water resources, the volume's decrease of groundwater storage, the generation of electricity, agriculture, soils, food, safety and human health. ${ }^{3}$ Therefore, the availability of free water will be reduced, affecting the human right to water. Also, the increase in droughts will shrink food production, affecting the human right to food. ${ }^{4}$ The rise of temperature alters the habitats and reproductive cycles, as well as species mobility, resulting in more poverty and human migration. Moreover, these environmental impacts will have consequences on the local economy, because it will change the location and behavior of species of commercial importance for local communities. The rights to life and health are being violated by the rise of temperatures, as well as changes in precipitation patterns and humidity, which consequently increase the transmission of vector diseases. ${ }^{5}$

The climatic impacts mentioned in the previous paragraphs result in losses and damages in economies, society, and natural resources, which must be compensated and repaired. In these circumstances, legal issues have emerged to demand compensation and reparation: "States shall develop national law regarding liability and compensation for the victims of pollution and other environmental damage. States shall also co-operate in an expeditious and more determined manner to develop further international law regarding liability and compensation for adverse effects of environmental damage caused by activities within their jurisdiction or control to areas beyond their jurisdiction". ${ }^{6}$ However, most attempts to develop an international or national law have been limited by the lack of a causal link between the causes and effects of climate change. Therefore, this article discusses how the causal link, the theory of attribution, and the theory of human rights, have a connection to demand binding obligations to repair and compensate the losses and damages of the adverse effects of climate change.

2 Andreas Fischlin et al., Ecosystems, their Properties, Goods, and Services, in Impacts, AdaPtation and Vulnerability. Contribution of Working Group II to the Fourth Assessment Report of the Intergovernmental Panel on Climate Change 21 1, 272 (Cambridge University Press) (2007).

3 Id.

4 Ulisses Confalonieri et al., Human Health, in Climate Change 2007: Impacts, Adaptation and Vulnerability. Contribution of Working Group II to the Fourth Assessment Report of the Intergovernmental Panel on Climate Change 391, 431 (Cambridge University Press) (2007).

5 Id.

6 U. N. The Rio Declaration on Environment and Development principle 13 (1992). 


\section{Summary of the Science of Glimate Ghange}

The lack of recognition to the existence of climate change, used to be a limitation for creating a national and international regulatory framework to address this global problem. Furthermore, scientific uncertainty has been used as an argument to reject or not acquire specific commitments assigning responsibilities to pay the costs that result from climate change. Additionally, natural climate variability over long periods of time has been used to deny that current climate change results from human activities. It was during, and after the industrial revolution that climate changes occur suddenly. With the record of an increase of greenhouse gases (GHGs) in the atmosphere, it was possible to establish that climate change is real, and a result of human activities carried out in developed countries. ${ }^{7}$ However, establishing that the Earth's climate system is changing abruptly was not always determined using computers and satellites. Therefore, it is important to analyze, to a certain extent, the path taken by the climate sciences to explain how, through the efforts of several scientists, it has been demonstrated that human activities have an effect on the climate system and, consequently, they are transforming ecosystems and the enjoyment of human rights.

The oldest records, that can be found in mythologies and legends, of climatic fluctuations date from approximately 3,000 years before Christ (BC). As catastrophic examples we can find the annual floods of the Nile; droughts with effects on food; long snowy winters that affected biodiversity, among others. Being part of ancestral legends, it is difficult to establish with certainty that these were climatic catastrophes, but they are fragments of the history of the world and are relevant when this problem is addressed. ${ }^{8}$ In particular, it was Aristotle in Greece who introduced the term Meteorology and made the first treatise dedicated exclusively to the atmosphere, consisting of four books known as Meteorology, and written around the year 340 BC. Moreover, the diary of Claudius Ptolemaeus, written around the year 120 after Christ $(\mathrm{AC})$ in Alexandria, is of great value because it recorded observations made for 171 days. Also, W. Haller kept weather records from 1546 to 1576, published later in 1872, and analyzed in $1949 .{ }^{9}$ That kind of research has

7 "Since the beginning of the industrial revolution, when people began burning fossil fuels, atmospheric concentrations of carbon dioxide (CO2) - the principal green-house gas (GHG) - have risen from about 280 parts per million (ppm) to more than $400 \mathrm{ppm}$, higher than at any time in the last 800,000 years" Daniel Bodansky eT Al., International Climate Change Law 1 (Oxford University Press) (2017).

8 Hubert Horace Lamb, Climate, Present, Past and Future. Volume 2, Climatic HisTORY AND THE Future 1, 2 (Methuen and Co. Ltd.) (1977). An Indian mythology tells of a period in which it rained for 12 years.

9 Thomas Gale Moore, Climate of Fear why we Shouldn't Worry about Global Warming 46 (Cato Institute Washington, D.C.) (1998). 
shown, that warmer climate is accompanied by more rainfall due to greater evaporation. ${ }^{10}$

The period where meteorological observations began to be measured using instruments emerged with the creation of the thermometer by Galileo Galilei in 1597, in connection with the invention of the barometer by Torricelli in 1643, and the anemometer created by Leon Battista Alberti and others. From 1654 to 1670 the Accademia del Cimento (Academy of Experiment) was created in Florence to make meteorological observations. Shortly after, in 1723 a Scheme for the collection of standardized weather reports was organized by James Jurin, under the auspices of the Royal Society, which was responsible for taking the daily records of meteorological observations to develop a timeline. Furthermore, another major source of data was provided by the Societas Meteorologica Palatina, founded at Mannheim in $1780 .{ }^{11}$

The first daily weather maps were drawn by H. W. Brandes in 1820 from the observations made at the Mannheim network for the year 1783. With the invention of the electric telegraph in 1850, it was possible to track the movement of storms and warn people about them. ${ }^{12}$ In several countries, the printing of maps of daily weather reports continued by 1873. Meanwhile, in New York, W. G. Redfield developed the first hurricane maps. As for the measurements of sea surface temperature, it is presumed that ships began to measure it around 1780. During the last years of the nineteenth century, observations and records of the climate were made systematically around the planet. ${ }^{13}$

During the year 1872 in Leipzig, Germany, a group of 52 meteorologists analyzed the possibility of creating an international cooperation mechanism in meteorology. The Professor Buys Ballot, then director of the Royal Netherlands Meteorological Institute, proposed in his essay "Suggestions on a uniform system of meteorological observations" an agreement for a uniform standardization of methods and meteorological observation units, as well as, a proposal to facilitate the exchange of weather information at the international level. ${ }^{14}$

The First International Meteorological Congress was held at Vienna in 1873, which resulted in a Permanent Meteorological Committee, composed of seven prestigious meteorologists, the President was the Professor Buys Bellot. The principal task of this committee was to draft the rules and statutes of an international meteorological organization. In 1879, the International

10 Stuart Houston et al., Eighteenth-Century Naturalists of Hudson Bay 114 (McGill-Queen's University Press) (2003).

11 J. A. Kington, The Societas Meteorologica Palatina: An Eighteenth-Century Meteorological Society, 20 (11) WEATHER 416, 426 (1974).

12 H. H. Lamb, Glimate, History and Modern World 318 (Routledge 1995) (1982).

13 Hubert Horace Lamb, Climate, Present, Past and Future. Volume 2, Climatic HisTORY AND THE Future, supra note 8 at 23, 27.

14 World Meteorological Organization, History OF IMO, https://public.wmo.int/en/aboutus/who-we-are/history-IMO. 
Meteorological Organization (IMO) was created during the International Meteorological Congress held at Rome, it remained working until 1950, the year in which the IMO officially became the World Meteorological Organization (WMO). ${ }^{15}$

In this context, in 1824, Joseph Fourier argued that the temperature of the Earth can increase by the interposition of the atmosphere. Years after, in 1836, Pouillet explained that the atmospheric stratum absorbs more the terrestrial rays than solar radiation, although it was not known which component of the atmosphere was responsible for that phenomenon. ${ }^{16}$ In 1859, John Tyndall identified that an increase in the radioactive components of the atmosphere could produce changes in the climate system. From 1873 to 1881 , Köppen proposed that the examination of the annual average temperature of different latitudes was an adequate technique to obtain a global temperature. ${ }^{17} \mathrm{Al}$ so, Svante Arrehnius identified an interaction between the heat retention effects of carbon dioxide $(\mathrm{CO} 2)$ and water steam. ${ }^{18}$

In 1938 Guy Stewart Callendar, using information provided by World Weather Records, produced a series of global temperatures which helped to realize what the influence of carbon dioxide on temperature is. ${ }^{19}$ Callendar solved a set of equations that linked greenhouse gases and climate change, establishing that by doubling the atmospheric CO2 the global average temperature would increase by $20 \mathrm{C}$, with greater warming at the poles. He linked this phenomenon with the burning of fossil fuels and its impact on the natural greenhouse effect. Moreover, Callendar said that the composition of the atmosphere is changing at an exceptional speed in geological time scales. ${ }^{20}$

The measurements of $\mathrm{CO} 2$ concentrations in the atmosphere were initiated by Charles David Keeling in 1958, the results were well-documented changes in the composition of the atmosphere, information considered iconic in the science of climate change. Therefore, an increase of CO2 in the atmosphere due to the burning of fossil fuels was taken as evidence to show the effects of human activities on the overall composition of the atmosphere. ${ }^{21}$

Nevertheless, the idea that $\mathrm{CO} 2$ is important to determine global changes in temperature, and that human activities have been responsible for changes in $\mathrm{CO} 2$ levels in the atmosphere, arose under the skepticism of many sci-

15 Id.

16 Hervé Le Treut et al., Historical Overview of Climate Change Science, in Contribution of Working Group I to the Fourth Assessment Report of the Intergovernmental Panel on Cimate Change 93, 127 (Cambridge University Press) (2007).

17 Id.

18 Hanna Knox, Thinking Like a Climate, 16 Issue 1: Political Materials: Rethinking Environment, Remaking Theory, Distiktion; Journal of Social Theory 91, 109 (2015).

19 In 1923 the World Weather Records was created, it gathered data about temperature, precipitation and pressure from hundreds of stations around the world.

20 Hervé Le Treut et al., Historical Overview of Climate Change Science, supra note 16 at 100-102.

21 Id. 
entists. $^{22}$ It was with the invention of the radiosonde in the decade of 1930 to 1940 , and with the invention of computer models, that meteorological science advanced in the analysis of great climate changes. The discovery of components such as Carbon 14 also helped, as well as the possibility to make precise observations in the atmosphere with pressure, temperature and humidity measurement. Finally, the analysis of great climate changes was reinforced describing the behavior of the atmospheric circulation in the hemispheres, alongside the operation of the laws that govern the development and direction of cyclones. ${ }^{23}$ Around 1970, other gases such as CH4, N2O and CFC, were recognized as important greenhouse gases. In 1990, greenhouse gases found in the atmosphere were higher than at any other time during the last half million years. Finally, with the development of satellites at the end of the 1950 s, the networks of planetary observations became a reality. ${ }^{24}$

Therefore, works and discoveries were oriented to the detection of climatic changes, to the attribution of the causes to the changes, and to predict what the effects of the changes in the climate would be. As for detection "... it is the process of demonstrating that the climate has changed in some definite statistical sense, without providing a reason for that change. The attribution of the causes of climate change is the process of establishing the most probable causes of the detected change with a defined level of confidence". ${ }^{25}$

Finally, as already mentioned, there were several attempts to organize meteorological observations to explain how and why the climate system is suddenly changing. However, these findings were considered important as a confirmation that sudden changes in the climate system have a negative impact on ecosystems and human beings. Furthermore, the development of climate change knowledge is crucial to determine who is responsible for paying the costs of the current global warming.

\section{Compensation for Loss and Damage Related to the Adverse Effects of Glimate Change}

\section{The Third Aspect of Climate Change Applicable After the Mitigation and Adaptation Policies}

The first international debates to recognize climate change as a global environmental problem, emphasized in taking measures and promote policies for climate change mitigation, mainly to reduce the emissions of Greenhouse

22 Hanna Knox, Thinking Like a Climate, supra note 18.

23 Hubert Horace Lamb, Glimate, Present, Past and Future. Volume 2, Glimatic HisTORY AND THE FUTURE, supra note 8 at 23, 27.

24 Id.

$25 I d$. 
Gases, and advocate towards climate change adaptation, adjusting infrastructure and public institutions to reduce the causes that result in climate change, providing for that purpose the conditions to resist the adverse effects. Such policies were established in the United Nations Framework Convention on Climate Change in 1992.

However, recognizing that anthropogenic climate change has and will have unavoidable adverse effects despite mitigation and adaptation policies, implies that the financial burden of the costs of losses and damages must be distributed fairly and proportionally. Those responsible for climate change should take responsibility compensating those who suffer the losses and, if possible, repair the damages related to this phenomenon. In this context, it has been suggested to address compensation and reparation for losses and damages related to the adverse effects of climate change, despite of mitigation and adaptation policies. ${ }^{26}$

The proposal of this third aspect of climate change has been developed considering the contributions of countries such as the Alliance of Small Island States (OASIS), with the recognition of principles of equity, international cooperation, as well as the identification of common but differentiated responsibilities, and respective capabilities. These actions encouraged the international community to adopt the Bali Action Plan (BAP) in 2007 and the Cancun Adaptation Framework (CAF) in 2010. In the BAP, the Conference of the Parties (COP) came to an agreement could, as a part of "enhanced action on adaptation", to consider addressing the losses and damages associated with the impacts of change climate change in developing countries, mostly those particularly vulnerable to the adverse effects of climate change. ${ }^{27}$ As a result, in 2013, the Warsaw International Mechanism for the losses and damages associated with the impacts of climate change was adopted.

To establish the Warsaw International Mechanism for Loss and Damage associated with Climate Change Impacts (Loss and Damage Mechanism), it was important to recognize that the adverse effects of climate change taken into consideration, included those that cannot be reduced through adaptation and mitigation policies. ${ }^{28}$ The three major functions of the mechanism are: a) Enhancing knowledge and understanding of comprehensive risk management approaches to address loss and damage associated with the adverse effects of climate change, including slow onset impacts. b) Strengthening dialogue, coordination, coherence and synergies among relevant stakeholders. $c$ ) Enhancing action and support, including finance, technology and capacitybuilding, to address loss and damage associated with the adverse effects of

26 Edward A Page \& Clare Heyward, Compensating for Climate Change Loss and Damage, 65 (2) Political Studies 356, 372 (2016).

27 Benoit Mayer, The International Law on Climate Change 184 (Cambridge University Press) (2018).

28 Id. 
climate change, which enable countries to undertake actions pursuant to decision 3/CP.18, paragraph $6 .^{29}$

Also, article 8 of the Paris Agreement mentions the importance of dealing with losses and damages related to the adverse effects of climate change through the Loss and Damage Mechanism. ${ }^{30}$ The problem with the Paris Agreement and the Damage Mechanism is that they have gaps to establish specific rules, for example, on establishing why, how, when and who is obliged to bear the financial burden of losses and damages related to the adverse effects of climate change. This problem results from two major aspects: A) To quantify and value the losses and damages to determine the total amount of compensation or reparation. B) To establish the causal links (cause-effect relationship) to decide who is responsible for bearing the financial burden. Nevertheless, as Page and Heyward mentioned, the Loss and Damage Mechanism has yet to specify how assistance will be provided or how the international finance will be transferred. Also, the Paris Agreement advocated for the Loss and Damage Mechanism do not establish who should finance it. ${ }^{31}$

In terms of losses and damages related to climate change, it ought to be considered as a plausible definition what was stated by the 2012 Framework Convention on Climate Change: "the actual and/or potential manifestation of impacts associated with climate change in developing countries that negatively affect human and natural systems". ${ }^{32}$ Specifically, losses are defined as "negative impacts in relation to which reparation or restoration is impossible, such as loss of freshwater resources",33 and damage as "negative impacts in relation to which reparation or restoration is possible, such as windstorm damage to the roof of a building, or damage to a coastal mangrove forest as a result of coastal surges". ${ }^{34}$ In the United Nations Framework Convention on Climate Change, loss and damage are equivalent to the adverse effects of climate change defined as: "means changes in the physical environment or biota resulting from climate change which have significant deleterious effects on the composition, resilience or productivity of natural and managed ecosystems or on the operation of socio-economic systems or on human health and welfare" ${ }^{35}$ Furthermore, the inequalities of climate change are the result of determining who causes climate change (emitters of greenhouse gases), who

29 C.P. De. 2/CP. 19, 6 Doc. FGCG/CP/2013/10/Add.1 (Jan. 31, 2014).

30 The Paris Agreement art. 8, Dec. 12, 2015, U.N.F.G.G.C/CP.

31 Edward A Page \& Clare Heyward, Compensating for Climate Change Loss and Damage, supra note 26 .

32 Framework Convention on Climate Change, Subsidiary Body for Implementation, 37, A literature review on the topics in the context of thematic area 2 of the work programme on loss and damage: a range of approaches to address loss and damage associated with the adverse effects of climate change, U.N. Doc. FGCG/SBI/2012/INF. 14 (Nov. 15, 2012).

$33 \mathrm{Id}$.

$34 \quad I d$.

35 United Nations Framework Convention on Climate Change art. 1, Jun. 4, 1992, U.N. 
receives the benefits, and who suffers the negative consequences. ${ }^{36}$ Thus, the problems are legal, philosophical, ethical, political and economic. Developing countries emit less greenhouse gases, however, they do not adapt to climate change and receive less benefits. One way to solve these problems is through compensation or reparation to restore the conditions or wealth to what it was before the interruption or the harm occurred. ${ }^{37}$

Regarding climate compensation methods, Page and Heyward quoting Goodin R., mention two methods: a) means-based compensation, b) endsbased compensation. ${ }^{38}$ According to Pages and Heyward, the compensation based on the means has the objective of leaving the agents in the same conditions they had before suffering the damages and the losses, restoring partially or totally the affected goods. Through this method we seek to repair, restore or replace an affected medium, which could be possible through the financial funds allocated for this purpose. Page and Heyward give the following case: "compensation is a financial award from an international compensatory fund or commission to an individual farmer for the purpose of replacing livestock or equipment after a climate change-related storm surge seriously damages their farm". ${ }^{39}$ In some cases it is impossible to make a compensation or repair. In this cases, Page and Heyward mention that it convenient to use "Satisfaction" measures. Within these measures are "Public apologies and commemoration, as well as reconciliation initiatives". ${ }^{40}$

In summary, climate compensatory approaches respond to losses and damages related to the adverse effects of climate change, making those affected able to integrate or recover the conditions, means and ends, in an equal or comparable state they had before adverse effects occur. These methods have obstacles that we can find in the characteristics that are generally used to describe climate change: global, progressive, unequal, urgent, etc.

\section{The Attribution and the Causal Link of Climate Change}

The compensatory models described above have been rejected by many policy makers, arguing that although it has been demonstrated with a high level of certainty that the current climate change is anthropogenic, it is not possible to demonstrate that climate change is the only cause of specific losses and damages. As catastrophic events often occur as a result of natural climat-

36 Bridget Lewis, Environmental Human Rights and Guimate Ghange. Gurrent StaTus and Future Prospects, Springer 151 (Queensland University of Technology) (2018).

37 Edward A Page \& Clare Heyward, Compensating for Climate Change Loss and Damage, supra note 26 .

38 Id.

39 Id.

40 Id. 
ic variability, the problem of attribution and causality emerges, on whether it is a result of human activities or from nature.

In these circumstances, the traditional legal processes to demand redress and compensation require attribution, and the latter requires causality. At the international level, a country shall demonstrate that an adverse effect associated with climate change is the result of excess greenhouse gas emissions from another country causing losses and damages in its jurisdiction. In the absence of conclusive evidence, the scientific answer is reduced to probabilistic causation. This problem represents the characteristic of climate change and its adverse effects, which cannot be verified, at least at this moment, the causal link that demonstrates the connection of the damage occurred in one place with the emission of greenhouse gases in another. Furthermore, the effects are not uniformly distributed worldwide, the most affected are the groups of scarce financial and technological resources in the developing countries. ${ }^{41}$ On this view, Pages and Heyward remark that the compensatory models are vulnerable to the objection that despite the fact that human activity have caused current climate change, it is not possible to prove that anthropogenic climate change was uniquely responsible for any particular loss or damage. ${ }^{42}$ Those who must receive compensation must prove that the losses and damages would not have occurred had it not been for the actions of the compensation providers. ${ }^{43}$

In these conditions, attributing damage responsibility to climate change faces two major difficulties: First, how does a physical event such as a flood needs to be attributed to climate change. Second, how are the consequences of these physical events on individuals, societies and ecosystems to be attributed. The difficulty of characterizing injuries and causal connections excludes the existence of reparation and compensation obligations. ${ }^{44}$ In a defensive manner, a compensation claim is more likely to be successful in establishing liability according to the amount of emissions a country has made, this means that states contribute to climate change in different proportions, according to the emissions made. ${ }^{45}$ From a theoretical perspective, countries that emit most of the greenhouse gases should compensate victims of their past and present activities which resulted in climate modification. Simultane-

41 Letcher Trevor M., Climate Change, Observed Impacts on Planet Earth 4 (Elsevier) (2009).

42 Edward A Page \& Clare Heyward, Compensating for Climate Change Loss and Damage, supra note 26 .

43 Barbara Saxler et al., International Liability for Transboundary Damage Arising from Stratospheric Aerosol Injections, 7 Law, Innovation and Technology 112, 147 (2015).

44 Benoit Mayer, The International Law on Climate Change, supra note 27.

45 John Knox, Linking Human Rights and Climate Change at the United Nations, 33 HarvarD Environmental Law Review 477, 498 (2009). John H. Knox, Climate Change and Human Rights Law, 50 Virginia Journal of International LaW 164, 218 (2009). 
ously, these countries should reduce and stop activities that transform the climate system. ${ }^{46}$

Furthermore, the causes and climate effects materialize in a transboundary environment, they are not limited to specific places. Actions that are carried out in one country could have negative repercussions in others as well. In this respect, Bridget Lewis says that the causes and effects of climate change generally operate internationally. ${ }^{47}$ As was previously mentioned, this represents the challenge of proving that the activities carried out in the jurisdiction, and under the control of one country has crossed its borders and affected human rights as well as the environment of other countries as well. The objective is to demonstrate that countries have violated the general principles of law where "States have the responsibility to ensure that activities within their jurisdiction or control do not cause damage to the environment of other States or of areas beyond the limits of national jurisdiction". ${ }^{48}$ Therefore, public international law must offer an efficient regulatory framework to address these issues, especially to regulate climatic impacts that are reflected in different times and places, exacerbating the problems that already existed (pre-existing challenges). ${ }^{49}$

Considering that States have more control of emissions in their jurisdictions,${ }^{50}$ some climate disputes are more likely to succeed than others. For instance, trials to reduce emissions, as Urgenda vs Netherlands, are more likely to thrive where the government (Dutch) was forced to reduce its emissions. However, countries do not have control of the consequences of their emissions inside or outside their territories. Therefore, trials to demand the compensation of human rights violation or ecosystems damage related to climate change are less likely to succeed. ${ }^{51}$ As in the case of the Inuit petition before the Inter-American Commission on Human Rights, where it was alleged that the emissions of the United States of America caused changes in the environmental conditions of the Inuit regions, such as the alteration of ice and snow patterns, which affected the ecosystems and human rights of Inuit people. At the same time, it has already been demonstrated that approximately from 1751 onwards, corporations such as Chevron, ExxonMobil, Saudi Aramco, BP and Gazprom head the list of the main industrial emitters of

46 Ian W. H. Parry, Fiscal Interactions and the Case for Carbon Taxes over Grandfathered Carbon Permits, 19:3 Oxford Review of Economic Policy 385, 399 (2003).

47 Id.

48 U. N. The Rio Declaration on Environment and Development principle 2 (1992). U. N. Convention on Biological Diversity article 3 (1992).

49 Benoit Mayer, The International Law on Climate Change, supra note 27.

50 Bridget Lewis, Environmental Human Rights and Climate Change. Current StaTus AND Future Prospects, supra note 36 at 185.

51 Id. at 152. 
CO2 and other elements such as methane, ${ }^{52}$ therefore, it is convenient to answer the following question: Are these these companies obliged to repair damages and losses related to climate change? The answer to this question is linked to market failures of certain economic activities that emit greenhouse gases, as well as activities of economic actors who add a financial burden to society by not paying the costs of these negative externalities. ${ }^{53}$

One way of including costs of loss and damage related to greenhouse gas emissions is through government regulations to internalize externalities. According to Spyridon Stavropoulos et al., regulations to internalize the externalities of economic activities can be grouped into two categories: commandand-control instruments and market-based instruments. ${ }^{54}$ The first category are regulations to control pollution, in which governments can impose sanctions or rewards to those who comply or breach the law. The second category is directed towards polluters, to pay the social and environmental costs of their activities. These regulations can be applied ex post or ex ante. ${ }^{55}$

In conclusion, the questions about which are the most adequate mechanisms of compensation for damages and climatic losses, are subject to the problem of attribution and causality, as a result from the characteristics of how these damages and losses are manifested in time and space. It is also taken in consideration the way in which they have been caused through diffuse pollution. Therefore, the costs that polluters must pay are lower than those society has to pay.

\section{The Theory of Human Rights and Compensation for Damages and Losses Related to Glimate Change}

This section will discuss the advantage and difficulties of addressing damage and climate loss through the perspective of the human rights theory, which has the purpose of supporting people who suffer the impacts of climate change. Also, it will be analyzed how States must comply with their obligations to protect human rights from the adverse effects of climate change. Considering that if human rights affected by climate change are guaranteed under international human rights law, and by many constitutions, then a claim on climate issues could be based on the objective of fulfilling, protecting or guaranteeing these rights from the adverse effects related to climate change. ${ }^{56}$

52 Säde Hormio, Can Corporations Have (Moral) Responsibility Regarding Climate Change Mitigation?, 20 Ethics, Policy \& Environment 314, 332 (2017).

53 Id.

54 Spyridon Stavropoulos et al., Environmental Regulations and Industrial Competitiveness: Evidence from China, 50 Applied Economics 1,378, 1,394 (2018).

55 Jonathan Baert Wiener, Global Environmental Regulation: Instrument Choice in Legal Context, 108 The Yale Law Journal 677, 800 (1999).

56 Bridget Lewis, Environmental Human Rights and Climate Change. Current StaTus and Future Prospects, supra note 36 at 152. 
The effects of climate change violate human rights, such as the right to health, food, water, housing, physical security, freedom of movement, selfdetermination, and even the right to life, all of them affected through environmental changes as a consequence of climate change. Remarkably, most human rights are guaranteed under important human rights treaties, with universal memberships, and by the constitutions of many countries (rights held by groups or by individuals, with different type of duties for States). Therefore, human rights theory offers a good opportunity to focus the international debate on climate change based on the priority of these rights, and to add pressure on the responsible parties. However, to prove injuries to human rights due to climate change does not determine who are responsible, and it is not a guarantee for an adequate compensation.

Regarding the incorporation of human rights principles in international treaties of climate change, Bridget Lewis argues that during the negotiations of the Paris Agreement in 2015, many States and non-governmental organizations proposed a strong reference of human rights in the text of the Agreement. ${ }^{57}$ However, under the influence of the powerful developed countries, this proposal gradually lost strength, and the final text of the Agreement only includes a provision for States "... action to address climate change, respect, promote and consider their respective obligations on human rights, the right to health, the rights of indigenous peoples, local communities, migrants, children, persons with disabilities and people in vulnerable situations and the right to development, as well as gender equality, empowerment of women and intergenerational equity". ${ }^{58}$ As Lewis argues, this appears in the preamble of the agreement and not in the operative part of the text, so the contribution of the Agreement to human rights and climate change is minimal. ${ }^{59}$ Theodor Rathgeber says that to integrate the climate with the human rights regime to protect vulnerable groups it is important to consider several dimensions, of which the author mentions:

1) The potential impact dimension: involves assessing the consequences of climate change, especially among members of vulnerable population groups.

2) The dimension of the mechanisms and instruments with which the consequences of climate change can be accurately identified in living conditions, and through which a litigation resolution process can be induced.

3) The dimension of adequate prioritization: it refers to both the urgency and the existential threat, in view of the irreversibility of certain meteorological processes that hinder access to resources, not guaranteeing

\footnotetext{
57 Id.

58 The Paris Agreement art. 8, Dec. 12, 2015, U.N.F.C.C.G/CP.

59 Bridget Lewis, Environmental Human Rights and Gumate Ghange. Gurrent StaTus AND Future Prospects, supra note 36 at 154.
} 
the subsistence and way of life of vulnerable groups facing the adverse effects associated with climate change. ${ }^{60}$

Furthermore, States have responsibilities over their citizens or those under their jurisdiction, without being accountable for those outside their jurisdiction. In this aspect, John Knox says that regardless of whether or not a State contributed or not to climate change, it does not exempt it from the responsibility for taking adaptation and mitigation measures. A State even has an obligation to reduce emission levels. ${ }^{61}$

However, this does not mean that the strongest obligation to reduce emissions is to those countries with less pollution.

The arguments mentioned in the previous paragraph, are in accordance with the distribution of the costs of managing the effects of climate change that developed countries must pay for their continuous and cumulative emissions. Edward A. Page mentioned three sub-principles to consider for supporting people affected by climate change; 1) Countries must compensate identifiable victims. 2) Countries should reduce the activities that transform the climate system. 3) Countries should fund measures to reduce the human costs of climate impacts that can no longer be avoided. ${ }^{62}$

Regarding the assessment of contributions to the problem of the costs of climate change effects, the polluter pays principle (PPP) is an economic-legal instrument that contributes to global responsibility towards the effects of climate change. Furthermore, this principle has a different perspective compared to that established in Article 3.1 of the United Nations Framework Convention on Climate Change, in relation to "common but differentiated responsibility based on respective capabilities". ${ }^{63}$ Therefore, from an economic perspective, the polluter pays principle that is applied through a variety of economic instruments, contributes to internalize the costs of environmental damages and losses, and it is important to protect and provide human rights affected by the effects of advertising related to climate change. ${ }^{64}$

In addition, the polluter pays principle improves current adaptation efforts, which fall into the category of what are called incremental adaptations: "Incremental adaptation represents familiar strategies of small changes to existing practices so as to sustain the functioning of existing socio-ecological

60 Theodor Rathgeber, Los Derechos Humanos ¿Guía en la lucha contra el cambio climático?, 23 Policy Paper Friedrich Ebert Stiftung, Fes-Ildis 1, 34 (2012).

61 Bridget Lewis, Environmental Human Rights and Climate Change. Current StaTus AND Future Prospects, supra note 36 at 178.

62 Edward A. Page, Distributing the Burdens of Climate Change, 17 Environmental Politics 556, 575 (2008).

63 United Nations Framework Convention on Climate Change art. 3.1, Jun. 4, 1992, U.N.

64 Mizan R. Khan, Polluters-Pays-Principle: The Cardinal Instrument for Addressing Climate Change, 4 (3)Journal Laws 638, 653 (2015) 
systems under climate change". ${ }^{65}$ However, these adaptation policies are, in some circumstances, insufficient to address transformational changes, which require new innovative strategies and government intervention, such as addressing the losses and harms of climate change as a third applicable aspect following the policies of mitigation and adaptation.

Lastly, some human rights can be interpreted as a cover of climate change consequences. For instance, the right to life in the case of an escalation of extreme weather events; the rights of indigenous people, the right to peace and security; the right to health (relevant when diseases increase); as many others. In the context of litigation, the approach of human rights could provide or found jurisdiction to determine what is the applicable law. Correspondingly, it is necessary to apply changes in the law or enactment news incorporating specific obligations, beyond international cooperation, for compensation and repair for damage and climate loss. ${ }^{66}$ It is important to bear in mind that the result of increased emissions of greenhouse gases of developed countries is only explained to society through the research from different sciences. ${ }^{67}$ Therefore, the possibility of addressing the challenge of climate change from an environmental and human rights perspective will be more likely to succeed incorporating scientific knowledge into the law.

\section{Conclusions}

International and national law must have a harmonious vision of climate change to develop a multisectoral approach to face challenges such as migration, food security, and humanitarian crises, all exacerbated due to global warming, extreme weather events, water stress, among others. In this sense, and aware that the current climate change is human-induced, it is possible to mention some climate responsibilities: the responsibility to limit or reduce the emission of greenhouse gases, the responsibility to maintain the decline of greenhouse gases, the responsibility to prevent climate damage, and the responsibility to invest for adaptation actions. However, these responsibilities are insufficient to pay the adverse effects of climate change. Therefore, it is also necessary to determine roles and responsibilities in compensation.

Attribution and causality in the context of climate change provide arguments to indicate critical points to prioritize financial support for damage and

65 Catrien J. A. M. Termeer et al., Transformational Change: Governance Interventions for Climate Change Adaptations from a Continuous Change Perspective, 60 (4) Journal of Environmental PlanNING AND MANAGEMENT 558, 576 (2017).

66 Richard Lord et al., Climate Change Liability 38, 40 (Cambridge University Press) (2011).

67 Jon Naustdalslid, Climate Change-The Challenge of Translating Scientific Knowledge into Action, 18 (3) International Journal of Sustainable Development \& World Ecology 243, 252 (2011). 
climate loss. Additionally, countries have a specific responsibility according to the amount of historical and current emissions (climate debt). Regarding the advantage of the human rights approach in the context of climate change, it should be interpreted as a protection towards the adverse effects of climate change as human rights violations.

Climate change issue of loss and damage is complex in its historical, generational, economic, ethical, philosophical, moral, and legal dimensions. Therefore, it is important to be aware of climate science history. Two important facts have been established by the climate sciences:

1) The atmosphere regulates the climate system and protects our planet, and it has negative consequences for ecosystems and humans when the greenhouse effect is altered.

2) Greenhouse gases have decomposed the chemical composition of the atmosphere, especially because of the burning of fossil fuels that increases the atmospheric Carbon Dioxide. These findings support the attribution and causal link theory of loss and damage related to climate change.

Finally, there is a challenge towards strengthening sufficient capitalization of international climate financial mechanisms. Due to the threats of certain developed countries to withdraw from important international treaties such as the Paris Agreement, a variety of financing institutions in the field of climate finance governance are losing billions of US dollars. 
Esta revista forma parte del acervo de la Biblioteca Jurídica Virtual del Instituto de Investigaciones Jurídicas de la UNAM juhttp://www.juridicas.unam.mx/ 


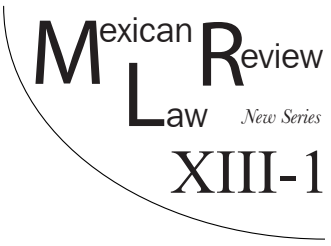

\title{
DRAFTING A CONSTITUTION IS NOT DRAFTING A STATUTE: AN ANALYSIS OF THE MEXICAN CONSTITUTION AND HYPER-AMENDING PATHOLOGIES FROM THE LEGISLATIVE DRAFTING PERSPEGTIVE
}

\author{
Jesús Manuel Orozco Pulido*
}

\begin{abstract}
This note critically examines the way the Mexican Constitution has changed since it was originally written, due to a large number of amendments. Through 239 decrees of constitutional reforms, which represent 732 modifications to constitutional articles, the current constitutional text is not the same document that arose from the Mexican Revolution. This vertiginous change is analyzed from the perspective of theoretical and practical notions of legislative drafting in common law countries. A huge number of reforms demonstrates a constitution's volatility, and the way reforms are written has a direct impact on whether or not it is observed. In fact, a proper process of redaction in legislative drafting can provide ideas for improving the quality of legislation. Reforming the constitution, as has been done by Mexican constituent powers, can overload the fundamental text with specific rules, rather than principles. An excessive use of words, an arbitrary use of subdivisions and an excessive number of transitory norms are common elements of constitutional amendments. Some specific traits of those amendments are analyzed in order to propose ways to improve the efficacy of the constitution through a better legislative drafting process for reforms. All of this in order to reach a better level of comprehension of the normative purpose of amendments by their final recipients: citizens and institutions.
\end{abstract}

Keywords: Mexican Constitution, legislative drafting, constitutional reform, legal efficacy.

RESUMEN: Esta nota critica la forma en que la constitución mexicana ha cambiado desde su texto original debido a un enorme número de reformas. A través de 239 decretos de reforma, que representan 732 modificaciones a sus artículos, la constitución actual no es el mismo texto que emanó de la revolución

* Attorney at law (University of Guadalajara) and Master in Parliamentary Procedures and Legislative Drafting (LUISS Guido Carli). Email: orozco.jesusmanuel@gmail.com. 
mexicana. Este cambio vertiginoso es analizado mediante herramientas teóricas y prácticas de la redacción normativa que tienen bastante difusión en países del common law. Un gran número de reformas muestra la volatilidad de la constitución, y la forma en que tales reformas se redactan incide en la observancia. Por ello, la redacción normativa tiende a dar ideas para mejorar la calidad de la legislación a través de una adecuada escritura. La reforma de la constitución, como se ha hecho en México, versa en sobrecargar el texto fundamental de reglas, en lugar de principios. También es común observar una utilización excesiva de palabras, el uso arbitrario de subdivisiones y un número desorbitante de articulos transitorios. Algunas características en especifico son analizadas a fin de proponer ideas que mejoren la eficacia de la constitución por la vía de una mejor redacción normativa de sus reformas. El fondo de la cuestión es lograr una mejor comprensión del mensaje normativo por los destinatarios finales de la reforma: los ciudadanos y las instituciones.

PALABRAS ClaVE: Constitución mexicana, redacción normativa, reforma constitucional, eficacia del Derecho.

Table of Contents

I. INTRODUCTION.

II. Hyper-Amending Pathologies and the Mexican

Constitution.

III. Is the Mexican Constitution a Well Drafted Document? ..... 209

IV. Examples of Constitutional Profuseness................................. 212

V. Future Scenarios .................................................................. 215

VI. Conclusions........................................................................ 216

\section{INTRODUCTION}

A constitution is the cornerstone of a legal system: it is the origin of the state; it determines the validity of the rest of the norms of a legal system; it proclaims the fundamental rights to which citizens are entitled; and it provides a framework for the exercise and control of power. ${ }^{1}$ Scholars have studied constitutions from theoretical and practical viewpoints, using legal, political and sociological criteria. However, specialized literature has rarely analyzed constitutions as texts, particularly ignored is the way they are drafted.

The Mexican Constitution dates from 1917, it was an outcome of the Mexican Revolution. ${ }^{2}$ It is recognized worldwide for being one of the first

1 Eduardo García de Enterría, La Constitución como nORMa y el tribunal constituCiOnal 49 (Civitas, Madrid, 1983).

2 Constitución Política de los Estados Unidos Mexicanos [Const.], as amended, Diario Oficial de la Federación [D.O.], 5 de febrero de 1917 (Mex.). 
constitutions that proclaimed social rights. However, the current constitutional text is not that similar to the original version, as a huge number of amendments have practically created a brand-new document. The main task of this note is to examine the way said amendments have an impact on the observance of the fundamental text.

In common law countries, the process of legislative drafting seeks to provide citizens with statutes that express normative purposes in the proper manner. Thus, the Mexican Constitution is examined here via the theoretical and practical tools proposed for legislative drafting. A crucial element of this analysis is connected to how the frequency of constitutional reforms and the particular way these reforms are drafted impact the observance of the magna carta.

\section{Hyper-Amending Pathologies and the Mexican Constitution}

The Mexican Constitution is one of the oldest constitutions in Latin America. No matter that this centenarian document is formally a rigid text - because the requirements for amending it are stricter than those for any other kind of legislation - in practice its rigidity has been banalized. Since its promulgation in 1917, the constitution has been amended by 239 decrees. The last reform considered in this note is the one published on August 9, 2019, regarding juridical recognition for Afro-Mexican communities. ${ }^{3}$ The huge number of amendments is an eloquent manner of showing the volatility of the constitutional text. The original text that emerged from the Mexican Revolution had just 21,000 words, whereas the current document has nearly three times as many. 4

The 239 decrees of reform can imply more than one amendment to a particular Article of the constitution, as one decree usually involves more than one article. If the counting of amendments is focused on the number of Articles that have been modified, the quantity is shocking: the Mexican Constitution has been modified 732 times. Only 22 Articles remain as they were, without any amendments from the original text. ${ }^{5}$ A decree modifies a certain topic in the constitution, and the normative articulation of the reform implies a mix of additions, derogations and rephrasings.

3 Data obtained from Mexican Chamber of Deputies, where Mexican constitution is published with all its reforms, http://wrere.diputados.gob.mx/LeyesBiblio/index.htm. Also, it is considered the counting made in Héctor Fix Fierro et al., Constitución Política de los Estados Unidos Mexicanos. Texto reordenado y consolidado 2 (UNAM, México) (2016).

4 Idem.

5 Mauro Rivera, Understanding Constitutional Amendments in Mexico: Perpetuum Mobile Constitution, IX Mexican Law Review, 3, 27, vol. IX (2017). 
The reform of the juridical regime of Mexico City, published on January 29, 2016, is a curious example. It modified 52 Articles of the constitution, which in numerical terms is equivalent to a third of the magna carta. The decree published on August 27, 2018, amended a transitory article of a previous constitutional amendment on February 10, 2014, in order to incorporate the new denomination of the Attorney's General Office to a previous electoral reform. The fact that constitutional reforms are passed in order to clarify a previous reform shows that there is little care to preserving the fundamental text.

Considering the huge number of times that Mexican Constitution has been amended - 239 decrees that contain 732 modifications to constitutional Articles - it is easy to see how the fundamental text is a normative product that easily adapts to the specific goals of the political class. Thus, the constitution adopts the shape that constituent powers want to give it according to particular circumstances. The ways and frequency with which it has been drafted over the last 100 years confirms this idea.

It is important to open a debate about how amendments to the constitution jeopardize compliance. In particular, it is necessary to consider that the way legislation is finally written - considering that a constitution is a legislative product that is also drafted - is related to the efficacy of norms, or in other words, their observance. Legislative drafting theories and practices shed more light on this issue.

Theoretical perspectives on legislative drafting enable a proper usage of normative documents. However, this is not an easy task. As Bowman stated, five different drafters will come up with five different bills, from this he concludes that legislative drafting is an art rather than a science. ${ }^{6}$ Indeed, a drafter has to be creative in order to translate in written, normative terms what exactly policy makers seek to achieve. When drafting such a crucial document the level of complexity increases, so writing a constitutional reform is not an easy task at all.

In order to facilitate drafting process, techniques have been developed, for example around plain language. Plain language permits norms to be written with precision, clarity and without ambiguity. ${ }^{7}$ For this purpose, there are golden rules to be considered, such as writing in the active voice, in the present tense, preferring shorter sentences rather than longer ones, careful wording, and using positive statements instead of negative ones. ${ }^{8}$ More specific tools, like flow charts, tables, indexes or explanatory notes, help to provide users of legislation with proper context so that they can appreciate the significance of what they read. ${ }^{9}$

6 Geoffrey Bowman, The art of legislative drafting, 7 European Journal of Law REForm, 3, 18 (2005).

7 Ruth Sullivan, The Promise of Plain Language Drafting, 47 MaGill Law Journal, 102, 103 (2001).

8 Geoffrey Bowman, The art of legislative drafting, op. cit.

9 Ruth Sullivan, The Promise of Plain Language Drafting, op. cit. 
The goal of legislative drafting is to make it easier to comply with the law. Some of those techniques should be applied to Mexican Constitution, which lacks efficacy. Its extended wording leads to miscomprehension and the excessive frequency of reforms does not allow for the cultivation of proper knowledge or application.

A constitution seeks to set guidelines for institutions as well as establish fundamental rights. It is important to write such key content in terms that are intelligible to all people. Regardless, the Mexican Constitution lacks a structure that allows for an easy identification of its basic traits, due to a hyperamending pathology. Regrettably, constitutional reforms have been written using a specific, thorough wording, that blurs the political principles set out in the magna carta. With its extended text and confusing terms, the Mexican Constitution runs contrary to the idea that a constitution is the recipient of essential principles that lead a nation.

Clarity in legislation facilitates the understanding of the message of the law. Nevertheless, when a legal clause involves refinements, conditions, exclusions and so forth, the application of law diminishes. ${ }^{10}$ In this sense, the Mexican Constitution lacks clarity, because its chapters are disorganized and its long, sprawling contents have become unintelligible due to the huge number of issues that are regulated with specificity, rather than regulated in a more general fashion.

The first chapter of the Mexican Constitution has a title referring to human rights and guarantees. However, within this chapter there are specific regulations about nine autonomous organizations that carry out activities outside of the umbrella of human rights, including: public universities, evaluation of education, governmental transparency and data protection, official statistics, social development, agrarian courts, national banking, economic competence, and telecommunications. In addition, other fundamental rights are contained outside this first chapter, such as labor rights established in Article 123. Moreover, guarantees for human rights are not even mentioned in the first chapter, much less regulated, contrary to the title. These guarantees - procedures on electoral jurisdiction, writ of amparo, constitutional controversies and actions of unconstitutionality - are regulated on Articles 99, 103, 105 and 107.

Sullivan identified a common problem with legislation, as it is drafted in long, convoluted sentences and relies on obscure jargon. ${ }^{11} \mathrm{~A}$ crucial task of a democratic state is to make the constitution an effective document. The work of the drafters is to improve the quality of legislation. These approaches should be mixed in order to enhance the quality, and therefore the efficacy, of the fundamental text.

The manner of writing a legal document is an urgent task for common law countries, which are pioneering the creation of academic programs that

10 Francis Bennion, The Readership of Legal Texts, 27 Clarity, 18 (1993).

11 Ruth Sullivan, The Promise of Plain Language Drafting, cit. 100. 
train professional drafters, ${ }^{12}$ establishing specific units of government lawyers specialized in drafting, ${ }^{13}$ or launching specialized literature on the issue.

However, the drafting of legislation in civil law countries is just beginning to take its first steps. In Mexico, constitutional studies are usually conducted for prescriptive or commemorative purposes, rather than for practical analysis. ${ }^{14}$ It is necessary to regard the constitution as a pragmatic document in order that it should have sufficient quality.

Real political change is camouflaged behind the hyper-amending pathology of the Mexican Constitution. In order to create the perception that the increase of constitutional clauses is just a reform and not a brand-new document, the number of articles remains the same, which is 136 . However, the specific content of those constitutional articles has vertiginously changed, as it is shown by its 239 amendment decrees, which contain 732 amendments to constitutional articles.

For instance, a decree published on January 29, 2016 gave birth to Mexico City as a geopolitical subnational entity, derogating its status as a Federal District. This reform modified 52 constitutional articles, mostly changing the words referring to the Federal District.

In fact, approximately 84 per cent of the original version of 1917 Constitution has been modified and the constitution is subject to a permanent change. ${ }^{15}$ From a practical and materialist viewpoint, the Mexican Constitution is not the same document that arose from the Revolution at the beginning of XX century. Although a developing country needs its foundational document to be up to the date, multiplying reforms damages its efficacy instead of enhancing it, because citizens and institutions no longer comprehend its meaning. Another negative effect is that politicians develop the idea that the constitution is not a barrier for avoiding excesses of power. Rather, it appears as an obstacle that is easy to remove through an amendment.

Upon closer examination, other deficiencies emerge. The fact that the constitution is written in complex, long winded sentences, and that a single reform usually involves several Articles, makes almost impossible to follow which constitutional norms are valid in a particular moment in time.

It is common to use vacation legis norms in order to leave a period of time in order to implement a reform. However, the Mexican Constitution sets out a complex variety of deadlines, so in the same reform there can be different dates for the entry into force, depending on the specific issue that is regulated.

12 For instance, the Institute of Advanced Legal Studies (SAS-University of London) offers LLM courses, clinics and summer programs specifically related to legislative drafting issues.

13 Office of the Parliamentary Counsel, 85, Drafting Guidance (2017).

14 Raymundo García García, Del institucionalismo histórico al neoinstitucionalismo en la docencia e investigación del constitucionalismo mexicano, in Constitucionalismo. Dos Siglos DE SU Nacimiento en América Latina 3, 22 (César Astudillo ed., UNAM, Mexico) (2013).

15 Mauro Rivera, Understanding Constitutional Amendments in Mexico: Perpetuum Mobile Constitution, cit. 
This complex regulation leads to confusion and does not set a definite time period for when a reform must be fully implemented. This is a hidden effect of constitutional mobility, since the constitutional order is regularly transformed by the final provisions of each decree.

In addition, transitory norms in decrees are excessive and create an unnecessary parallel context for the implementation of constitutional reforms. For instance, the original constitution of February $5^{\text {th }}, 1917$, had only nineteen transitory articles. Considering that the constitution was written during a transitional period following a revolution, this seems to be a coherent number.

Nowadays there is a trend towards maximizing the use of transitory articles in order to reinforce the implementation of reforms. More than just considering the time for the entry into force of the reform, or a derogatory provision, in Mexico transitory articles of constitutional reform decrees also specify rules for the appointment of high level officers and other detailed provisions that would be better developed in secondary legislation.

For instance, the government transparency reform published on February 7 th, 2014, foresees in transitory articles a complete calendar for the replacement of each public official of the transparency institute. The political reform of February $10^{\text {th }}, 2014$, has twenty one transitory articles that foresee a wide variety of rules, including the contents of basic norms that shall be developed by secondary legislation. These are normative requirements that would be properly foreseen in the constitution and not in transitory articles. The education reform of May 15th, 2019, includes eighteen transitory articles and sets complex rules related to the contents and implementation of the reform.

Constituent powers for amending the constitution, which involves the national Congress and subnational legislative assemblies, should only be implemented for core topics. There should be space for secondary legislation, so that as legislatures develop constitutional clauses, the constitution does not become a catch-all, but just the point of reference.

Besides its legal implications, the large number of reforms creates a social perception that amending the constitution is as simple as creating another piece of legislation. If the constitution is not a thick barrier that protects the empire of law, it becomes just another layer that is easily removed.

\section{Is the Mexican Constitution a WeLl DRAFted document?}

A constitution is supposed to guarantee the basic needs of the State and its inhabitants. Constitutional clauses should be constantly exercised by their final receivers: citizens and institutions. If a constitution is only reserved for a political and legal elite, the link between a people and their fundamental document is broken. Regrettably, this is the case of Mexican Constitution.

People need to know what fundamental rights they are entitled to their welfare, and which limits exist for controlling power. When constitutional 
knowledge is lacking, any infringement to the legal order might become banalized and citizen interest in pursuing their rights would diminish.

Overloading a constitution with ambitious rights or brand new institutional models that are unreachable also leads to the inobservance. ${ }^{16}$ If there is a lack of means to meet requirements, a constitution becomes nothing more than an aspirational document that agglutinates the best desires of the state, but it is not considered a real norm to be respected and of which inobservance implies an abdication of responsibilities.

If the constitution is merely a symbolic document with hollow clauses and contents, it will become a dead letter, no matter the effort made by a constitutional assembly to draft it. In fact, according to Latinobarometer, Mexico is the Latin American country in which citizens have the poorest level of attachment with the law, and where behaviors are guided by self-consciousness rather that by norms. ${ }^{17}$

Legal philosopher Nino described anomia as a predisposition for not respecting norms, showing a lack of interest to fulfill the democratic aspirations enshrined in the rule of law. ${ }^{18}$ Constitutional anomia is a common phenomena in Mexico. The constitution is there, everybody sees it, but its principles and rules are not observed. Part of the problem is related to the overloading of contents of the fundamental text, and another part is that no drafter took a pause in order to better write the reforms.

Efficacy of law, understood as the quality of norms to meet goals to such a degree that judicial interpretation is not necessary, ${ }^{19}$ is a common, contemporary concern in law. Plenty of new legislation is passed each year in parliaments and congresses in Mexico, but the general situation is not encouraging at all.

According to Jones, the lack of means for communicating the law's message minimize its enforcement. ${ }^{20}$ This factor also emerges when studying the situation of the Mexican Constitution. After the enormous number of amendments, not even the average lawyer is aware of what specific contents are enshrined in the highest norm. Because of this, some arrangements should be made.

Common law tradition has been built on the basis of legal precedents dictated by courts, but these are not the only source of law. Acts and statutes

16 Giovanni Sartori, Ingeniería constitucional comparada. Una investigación de ESTructuras, incentivos y Resultados, (Fondo de Cultura Económica, 2a. ed., México, 2001) (1994).

17 Latinobarómetro, Informe Latinobarómetro 2018, https:///C:/Users/HP/Downloads/INFOR ME_2018_LATINOBAROMETRO.pdf.

18 Carlos Nino, Un país al margen de la ley, (Ariel, Buenos Aires, 2014) (1992).

19 Helen Xanthaki, On Transferability of Legislative Solutions: The Functionality Test, in Drafting Legislation, A Modern Approach 5 (Routledge, London, 2016).

20 Harry W. Jones, The Efficacy of the Law, 18, 20, 32, 34 (Northwestern University Press) (1969). 
passed by a parliament or a congress provide the general legal framework, and then the final receivers of law have to find precedents that provide a concrete solution to a given case. It is common practice for a legal addressee to carry out a paper chase of relevant legal material that provide him or her with existing statutory law and updated precedents. ${ }^{21}$ Internationally, parliaments have even begun putting in practice a consolidation of legal systems in order to organize all the rules on a specific area in a single document.

The point of these efforts is not necessarily to codify a particular branch of law, as doing so would require the creation of new legislation. ${ }^{22}$ Rather, consolidation prevents people from getting lost in the legal system when they are trying to find relevant provisions. Consolidation enables easier access to justice. ${ }^{23} \mathrm{~A}$ similar exercise should be emulated in the Mexican constitutional context. Some steps have been taken in this regard, such as procedural rules on criminal, civil and family trials that are now regulated by federal Congress through a national code, as was foreseen by constitutional reforms published on June 18, 2008 and September 15, 2017.

It is not even clear what the structure of the constitution is. Traditionally, each constitutional article is divided into paragraphs, each of which sets up one idea for a regulatory purpose. Parts are then used in order to enumerate (with roman numerals, starting with I, and so forth) more detailed norms, for example Articles 31, 55 and 107.

As the details of a regulation proceed, incises with lower letters are used, starting with a), and so on, such as Article 105. When the same article regulates a variety of topics, it is usually divided into sections divided by capitalized letters from A to $\mathrm{Z}$. This is the case of Article 102, which paradoxically in section A regulates the Attorney General's Office and in section B regulates the Ombudsman.

The drafters of Mexican Constitution have used a variety of forms to divide a single article, without following the same criteria. A paradigmatic example is Article 41, a catch-all article that is also one of the lengthiest, that mixes parts, sections and incises. Article 72 introduced an arbitrary division in sections with capital letters rather than with fractions with roman numerals, as tradition would have it.

Drafters of the Decree of February 10, 1949, likewise, introduced a peculiar division using parts, numbers and incises, all of them arbitrarily appearing in the same constitutional article. The same defect is present in Article 123, which most peculiar regulation is on part XXIX, incise a), numbers 1 to 22. This complex regulation foresees the federal jurisdiction for labor trials related to certain industrial activities.

21 Alec Samuel, Consolidation: A plea, 26 Statute Law Review, 59, Oxford University Press (2005).

22 Idem.

23 Patricia Rickard-Clarke, Access to justice: accessibility, Statute Law Review 159, 164, Oxford University Press (2011). 
Returning to the thrust of this article, we see that the Mexican Constitution has been drafted without attention to a precious rule of normative drafting: concreteness and organization. Moreover, the constitution contains absurd clauses that should be derogated, as they would fit better within secondary legislation.

For instance, Article 47 defines the territorial borders of Nayarit, a subnational state. Article 28 regulates the procedure for choosing commissioners of autonomous regulatory organizations with profuse explicitness. Article 41 regulates the number of minutes of TV advertising that should be allocated to political parties. A reform published on June 17, 2014, foresees a fourth transitory article establishing that the Ministry of Government has the duty to transfer death certificates to the National Electoral Institute. Adding meaningless norms overloads the constitution, negatively impacting comprehension and taking away from the importance of the magna carta.

When Legislative power amends the legal system, there is an aspiration to create a better context, so the norms approved have a positive impact on society. It is crucial that a new approach for reforming the Mexican Constitution be adopted, cutting excessive wording that debilitates the final regulatory message. Instead, short, concrete principles and specific basic rules must be included in the constitution, giving it a heavier weight in legal culture.

\section{Examples of Constitutional Profuseness}

On the eve of the centenary commemoration of Mexican Constitution, a commission formed by renowned scholars revisited the constitution in order to propose technical improvements. ${ }^{24}$ The goal was to produce a coherent and accessible document, and not a compendium of specific regulations that should be contained in a secondary norms. This work should continue.

We can find many examples of overregulation in the federal system. Today, Mexican federalism in the constitution is blurred, in part because central government has absorbed almost all relevant attributions. The allocation of competences in Mexico works such that specific attributions in the constitution belong to the federal scheme, while those that are unwritten belong to the subnational entities. Article 73 foresees competences that yield the scope of federal power, while Article 124 establishes a residual clause through which subnational states assume competences that are not expressly conferred to the federation.

In the original text of the 1917 Constitution, Article 73 had thirty subsections which listed the subjects that are the exclusive competence of the national Congress. Today, the number of parts remains the same. However, Part

24 This Commission was led by renowned professors Diego Valadés and Héctor Fix, both from UNAM. 
XXIX of Article 73 has dramatically expanded - and the same phenomenon has occurred in Article 4, which has absorbed almost all the reforms related with social or economic rights-. The original version of Article 73, part XXIX, had subheadings from XXIX-A to XXIX-H, today the list of subheadings reaches XXIX-Z. Since there are no more letters available to be used in this subsection, another constitutional space will need to be found to hold future centralistic amendments. At the end of the day, as stated before, roman or arabic numerals, incises, or letters are arbitrarily used in the constitution.

From the perspective of legislative drafting, it would be better to create a specific article in the constitution that describes the centralistic traits of government, rather than increasing the attributions of federal power in a section which was originally limited to the core functions of the state. Considering that form and content are intrinsically connected, drafters have to deal with the content of legislation in order to find appropriate words to communicate the political message they wish to convey. ${ }^{25}$

A contemporary complaint in Mexican constitutionalism is that federal system is but a reminiscence of the origins of the republic, but in practice, the government is highly centralized. ${ }^{26}$ It is childish to think that only reforms to the constitution have a direct impact on the efficiency of laws. It is also necessary to define transversal policies and budgets in order to achieve goals.

A similar phenomenon took place during the constitutional reform of June 18, 2008 which introduced a new model of criminal justice. So far constitutional reform has not been an effective method of transforming the justice system, because the practices of prosecutors, barristers and the judiciary remain the same. Constitutional reforms in Mexico lack pragmatic, political and budgetary schemes that enable proper implementation. Those trying to apply the constitution are walking blind when trying to meet the objectives of reforms.

Another example is the reform published on August 24th, 2009, which modified Article 127 in order to create a threshold for salaries in public service, ensuring no public servant could earn more than the President of the Republic. Said reform established a vacation legis period of six months in order to create and harmonize secondary legislation with constitutional amendments. However, it wasn't until 2018 that secondary legislation was approved (Federal Act for Remunerations of Public Officials), which was challenged before the Supreme Court by senators and the national Ombudsman. ${ }^{27}$ Judicial review of this legislation provoked a challenging encounter between the

25 Ann Seidman et al., Legislative Drafting for Democratic Social Change: A ManuAL FOR DRAFTERS, 26 (Kluwer Law International) (2011).

26 José María Serna, El sistema federal mexicano. Un análisis Jurídico (UNAM, Méxiсо) (2008).

27 Actions of unconstitutionality 105/2018 and 108/2018, ruled on May 20th, 2019. PLEno de la Suprema Corte de Justicia de la Nación [S.G.J.N.] [Supreme Court]. 
Morena party and Supreme Court justices. Also, more than twenty thousand of individual writs of amparo lodged by public servants challenged that federal act.

Besides specific arguments regarding the scrutiny of secondary legislation, this problem could have been prevented if constitutional reform of 2009 had been sufficiently expanded and explained. What was needed was in fact a profound social and political debate on the limits of salaries paid to public servants. Congress failed to respect deadlines set in the constitution for the timely approval of complementary legislation. Both elements were absent, and by the time legislation related to the constitutional clause was published, the resulting debate was shockingly misunderstood. There are lessons should be learned from this experience.

According to Hunt, ${ }^{28}$ when amending legislation, an opportunity for updating the language contained within it arises. This was taken in mind on June 10, 2011 in the reform that renamed first chapter of the constitution, so it refers to human rights instead of individual guarantees. Adapting a name concordant with contemporary terminology has its merits. But if the real political aim was to make human rights a point of reference for all Mexican authorities, it would have been better to re-accommodate human rights into one chapter and remove topics that have no relation on it.

Mexico does not have a tradition of writing preambles in legislation. So the constitution lacks a foreword that facilitates a popular understanding of its magna carta. In other legal systems, when trying to identify the real meaning of a statute, it is common to analyze the travaux préparatoires, such as the original draft of the bill, legislative debates, and legal reports prepared by commissions from both chambers of congress. ${ }^{29}$ Regrettably, when a reform is published there is a lack of information for the debates that are held in Congress.

Interpreting what a constitutional assembly was aiming to achieve is technical and complicated work. Interpreting the constitution requires methods that are not the same as those used for interpreting ordinary legislation. ${ }^{30}$ Judges, lawyers, members of Congress and citizens should not conduct the interpretation of the constitution with exegetic techniques, or by literal or systemic methods. Interpreting the constitution requires putting its clauses under a microscope in order to understand details, and then zooming out to see what practical consequences the constitutional assembly wanted to achieve.

28 Brian Hunt, Plain Language in Legislative Drafting: Is it Really the Answer? 23 OXFoRd UnIversity PREss, 24, 46 (2002).

29 Timothy J Arnold-Moore, Point-in-time publication of legislation (XML and legislation) Automating Consolidation of Amendments to Legislation in Common Law and Civil Law furisdictions, JourneE INTERNET POUR LE DROIT (2004), http://wrerr:frlii.org/spip.php?article67.

30 Riccardo Guastini, Estudios sobre la interpretación jurídica (Marina Gascón trans., UNAM, 5d ed., 2003) (1999). 
Interpreting statutes and bills is a task carried out by judges, who need to be trusted by citizens and institutions in order to act with legitimacy and increase the efficiency of their rulings. ${ }^{31}$ In countries such as the United States, judges have played a key role in the struggle for rights. ${ }^{32}$ It is crucial to have a well drafted constitution that allows brave interpretations, especially interpretations made by Supreme Court.

Concreteness on constitutional clauses enhances argumentation in courts, as when the message of the law is circumscribed within few words, constitutional judges tend to maximize and deepen the reach of the norm. On the contrary, when a constitutional clause is profuse and thorough, the message of the law is banalized, leaving little space for judicial creation, or even imagination. This argument is supported by observing the huge number of judicial precedents that have emerged around Article 16 of the Mexican Constitution, which stipulates that all activities of the state must be based on law and motivated by facts. The same thing occurs with Article 103, in which three parts establish the writ of amparo as a guarantee that allows citizens to defend their fundamental rights.

Those plain, concrete constitutional messages have been interpreted by high courts enough to determine what aspects fall under the umbrella of concrete constitutional exigencies. The same effect occurs with citizens, who have but a general picture or even repeat from memory what the constitution means in their daily life. A kind of day-to-day reaffirmation of the constitution emerges, because the fundamental text actually serves for solving public struggles.

\section{Future Scenarios}

When the ship of the rule of law is sinking, as is happening in Mexico, it could be thought that the constitution is the only passenger who will remain afloat. It is necessary to enshrine all political agreements into the constitution, so that compliance becomes stricter. Nevertheless, it is paradoxical that instead of putting in efforts to improve implementation and compliance of secondary legislation, the problem of non-observance is transferred from regular legislation to the constitution. ${ }^{33}$

It appears that this phenomenon will not end, as the trend of governing and legislating from the constitution is presented as a solution. Over the last

31 Francis Bennion, Legislative Technique, The Science of Interpretation, 130 New Law Journals, 493 (1980).

32 Martin Shapiro, Revisión judicial en democracias desarrolladas, in Tribunales Constitucionales y Democracia 233, 262 (SCJN, México) (2010).

33 According to De Benedetto, ineffectiveness of law is usually transferred to micro towards macro scenarios. Maria De Benedetto, Why do we need effective law? Keynote address at the Institute of Advanced Legal Studies of the University of London (July 7th, 2017). 
three presidential administrations, the percentage of global constitutional amendments has increased enormously. Under the administration of President Felipe Calderón, 38 amendment were approved, President Peña Nieto passed 28, and 6 have been adopted in the first year of President Lopez Obrador's administration. ${ }^{34}$

Some constitutional reforms require extensive secondary legislation, as with criminal justice or technical subjects such as energy or telecommunications. Professional drafters argue that the quality of legislation decreases when rushing deliberative processes which are not clear enough. ${ }^{35}$

The same holes can be observed in the amending process, in terms of the automatic approval of constitutional reform by subnational congresses. No discussions or debates are triggered in order to justify why a subnational State has given its approval to a federal constitutional reform. It appears as just another procedural trait: after the national Congress approves the reform, each local congress automatically ratifies the core decision. In terms of the quality of legislation, no process is conducted by which local congresses bring the specific contents that were approved in the constitutional reform into their local sphere. A lack of empathy between reforms and their final receivers is repeated because there is no socialization of constitutional reforms.

\section{Conclusions}

If a constitutional culture is not properly disseminated, the possibility for the abuse of power increases. One step forward to strengthening the constitution is to draft it properly, in order to make messages of law clearer. Mexico has a hyper-amending pathology that shows no signs of recovery. At some point, this process will end up with a either a brand-new constitution or with a reorganization of the current text.

It is time to open the debate as to how to draft future amendments. The shorter constitutional amendments are when they are drafted, the more effective they will be, as more chances will be given to secondary legislation and courts to develop the rule of law based on strong constitutional principles.

There are lessons to be learned from studies of legislative drafting in the tradition of common law. Concreteness and assertiveness are elements that have been forgotten in drafting Mexican Constitution. It is past time to neutralize this hyper-amending tendency, and to recover the idea that a constitution is not just a regular statute. A constitution should not contain the minute details of legal systems, rather its core principles.

34 Héctor Fix Fierro et al., Constitución política de los estados unidos mexicanos.

TEXTO REORDENADO Y CONSOLIDADO, cit.

35 Victoria Nourse \& Jane Schacter, The Politics of Legislative Drafting: A Congressional Case Study, 77 New York University Law Review, 575, 624 (2002). 
Legislative drafting practices from common law traditions can provide Mexican constituent powers with tools to help them to create better legislation, including a better constitution. The process of writing an act, socializing its contents, and publishing the preparatory working material of legislative process, would produce a higher quality constitutional text. The easier to understand a written norm is, the more probable it is that it will be complied with. 